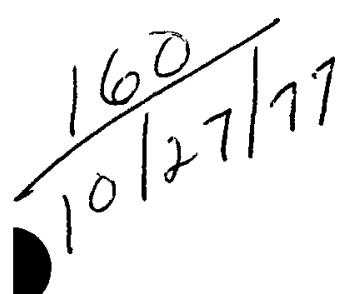

GA-A 14274

UC-77

\title{
STAT, GAPS, STRAIN, DRWDIM A SYSTEM OF COMPUTER CODES FOR ANALYZING HTGR FUEL TEST ELEMENT METROLOGY DATA USER'S MANUAL
}

\author{
by \\ J. J. SAURWEIN
}

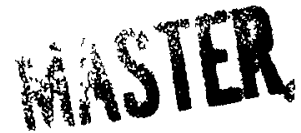

Prepared under

Contract EY-76-C-03-0167

Project Agreement No. 17

for the San Francisco Operations Office

U.S. Energy Research and Development Administration

DATE PUBLISHED: AUGUST 1977 


\section{NOTICE}

Ihu report was prepared as an account of work sponsored by the United States Government. Neither the l'mited States nor the United States Fneigy Reseath and Development Administration, noi any of their emplovees, nor any of their contractors, subcontractors, or then employees, makes any wandnt, express or implied, or assumes any legal liability or responsibility fot the accuracy, completeness or usefulness of any information, apparatus, product or process disclosed, or epresents that ats use would not infruge privately owned rights.

Printed in the United States of America

Available from

National Technical Information Service

U.S. Department of Commerce

5285 Port Royal Road

Springfield, Virginia 22161

Price: Printed Copy $\$ 7.75$, Microfiche $\$ 3.00$

9.25 


\section{DISCLAIMER}

This report was prepared as an account of work sponsored by an agency of the United States Government. Neither the United States Government nor any agency Thereof, nor any of their employees, makes any warranty, express or implied, or assumes any legal liability or responsibility for the accuracy, completeness, or usefulness of any information, apparatus, product, or process disclosed, or represents that its use would not infringe privately owned rights. Reference herein to any specific commercial product, process, or service by trade name, trademark, manufacturer, or otherwise does not necessarily constitute or imply its endorsement, recommendation, or favoring by the United States Government or any agency thereof. The views and opinions of authors expressed herein do not necessarily state or reflect those of the United States Government or any agency thereof. 


\section{DISCLAIMER}

Portions of this document may be illegible in electronic image products. Images are produced from the best available original document. 
GA-A 14274

UC-77

\title{
STAT, GAPS, STRAIN, DRWDIM A SYSTEM OF COMPUTER CODES FOR ANALYZING HTGR FUEL TEST ELEMENT METROLOGY DATA USER'S MANUAL
}

\author{
by \\ J. J. SAURWEIN \\ Prepared under \\ Contract EY-76-C-03-0167 \\ Project Agreement No. 17 \\ for the San Francisco Operations Office \\ U.S. Energy Research and Development Administration
}

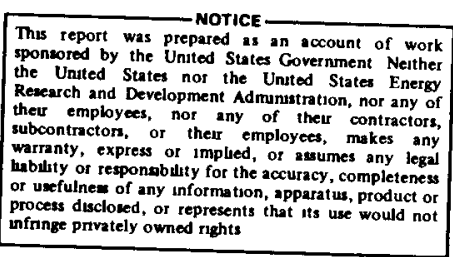

pponsored by was prepared as an account of work the United States not the United States Fneres Research and Development Admuntitration, nor any of 
-

0 
ABSTRACT

A system of computer codes has been developed to statistically reduce Peach Bottom fuel test element metrology data and to compare the material strains and fuel rod - fuel hole gaps computed from these data with HTGR design code predictions. The codes included in this system are STAT, STRAIN, GAPS, and DRWDIM. The function of each is summarized below.

STAT - Statistically evaluates test element metrology data yielding fuel rod, fuel body, and sleeve irradiation-induced strains; fuel rod anisotropy; and additional data characterizing each analyzed fuel element.

STRAIN - Compares test element fuel rod and fuel body irradiationinduced strains computed from metrology data with the corresponding design code predictions.

GAPS - Compares test element fuel rod - fuel hole heat transfer gaps computed from metrology data with the corresponding design code predictions.

DRWDIM - Plots the measured and predicted gaps and strains.

Although specifically developed to expedite the analysis of Peach Bottom fuel test elements, this system can be applied, without extensive modification, to the analysis of Fort St. Vrain or other HTGR-type fuel test elements.

This document was prepared in order to provide potential users with the know-how required to make use of each of the codes in this system. 
•

• 
CONTENTS

ABSTRACT .......................... . . . . . . . . . . . . . .

1. INTRODUCTION . . . . . . . . . . . . . . . . . . 1-1

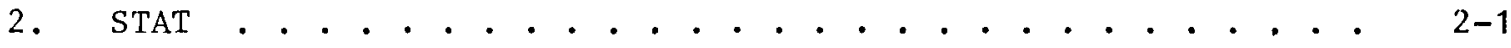

2.1. Calculations . . . . . . . . . . . . . 2-1

2.1.1. Total Element Length and Fuel Body Weight

Calculations . . . . . . . . . . 2-8

2.1.2. Fuel Rod Calculations . . . . . . . . 2-8

2.1.3. Fuel Body Calculations . . . . . . . . 2-9

2.1.4. Fuel Hole Diameter Calculations . . . . . 2-10

2.1.5. Sleeve Calculations ........... . 2-10

2.1.6. Fuel Stack Calculations .......... . 2-11

2.2. Structure ................. 2-12

2.3. Program Limits.................. 2-14

2.4. Input .................... 2-15

2.5. Output.................... 2-17

2.6. Usage Considerations . . . . . . . . . . . 2-17

3. STRAIN . . . . . . . . . . . . . . . . . . . 3-1

3.1. Calculations . . . . . . . . . . . . . . 3-1

3.1.1. Group 1 Calculations . . . . . . . . 3-2

3.1.2. Group 2 Calculations ........... . 3-4

3.2. Structure .................. 3-4

3.3 Program Limits................ 3-7

3.4. Input .................... 3-8

3.5. Output . . . . . . . . . . . . . 3-8

3.6. Usage Considerations . . . . . . . . . . . 3-9

4. GAPS .................... . . . . . 4-1

4.1. Calculations . . . . . . . . . . . . . . 4-1

4.1.1. Comparison of Measured and Predicted Fuel
Rod - Fuel Hole Gaps . . . . . . . . . 4-2

4.1.2. Fuel Rod - Fuel Hole Gap Calculations . . . . 4-7 
4.1.3. Sleeve - Fuel Body Gap Calculations (Based on Sleeve O.D.)............ . 4-7

4.1.4. Sleeve - Fuel Body Gap Calculations (Based on Sleeve I.D.)........... . 4-9

4.2. Structure ................. 4-9

4.3. Program Limits .................. 4-10

4.4. Input ..................... $4-11$

4.5. Output .................... 4-13

4.6. Usage Considerations ............... 4-13

5. DRWDIM . . . . . . . . . . . . . . . . . 5-1

REFERENCES . . . . . . . . . . . . . . . . . . . . R-1

APPENDIX A: STAT INPUT INSTRUCTIONS

APPENDIX B: STAT SAMPLE PROBLEM

Control Cards . . . . . . . . . . . . . . B-1

Input Data File . . . . . . . . . . . . . B-2

Key to Symbols in Results Tables . . . . . . . B-17

Printed Output . . . . . . . . . . . . B-18

Punched Card Output . . . . . . . . . . . B-51

APPENDIX C: STRAIN INPUT INSTRUCTIONS

APPENDIX D: STRAIN SAMPLE PROBLEM

Control Cards . . . . . . . . . . . . D D-1

Input Data Deck . . . . . . . . . . . . . D-1

Printed Output ............... . D-3

Punched Card Output . . . . . . . . . . . D-8

APPENDIX E: GAPS INPUT INSTRUCTIONS

APPENDIX F: GAPS SAMPLE PROBLEM

Control Cards . . . . . . . . . . . . . F F-1

Input Data Deck . . . . . . . . . . . . . . F-1

Printed Output . . . . . . . . . . . . F-5

Punched Card Output . . . . . . . . . . . F-38

APPENDIX G: DRWDIM INPUT INSTRUCTIONS

APPENDIX H: DRWDIM SAMPLE PROBLEM

Control Cards and Program Deck . . . . . . . . H-1

Input Data Deck . . . . . . . . . . . . H-2

Plotted Results................ . . H-8 


\section{FIGURES}

1-1. Fuel test element assembly . . . . . . . . . . . . 1-2

1-2. Flow of information through data reduction system . . . . 1-3

\section{TABLES}

2-1. Basic calculations performed by STAT . . . . . . . . . 2-3

2-2. Equations used for stratification . . . . . . . . . . . 2-5

2-3. Errors associated with Peach Bottom fuel test element metrology . . . . . . . . . . . . . . . . . 2-7

3-1. Equations for computing and comparing fuel rod and fuel body strains... . . . . . . . . . . . . . 3-3

3-2. Equations for fuel body average and test element average calculations... . . . . . . . . . . . . 3-5

4-1. Equations for computing and comparing fuel rod - fuel hole gaps . . . . . . . . . . . . . . . . . 4-3

4-2. Equations for computing postirradiation fuel hole and inner sleeve diameters and errors . . . . . . . . . . . 4-5

4-3. Equations for fuel rod - fuel hole and sleeve - fuel body gap calculations... . . . . . . . . . . . 4-8 


\section{INTRODUCTION}

Two of the objectives of the test element program being conducted by General Atomic are to demonstrate the dimensional stability of fuel element components and to confirm the calculational methods for therma1 performance and material strain. The Peach Bottom series of the test element program included 33 fuel test elements, 20 of which underwent postirradiation examination (PIE). The structure of a typical Peach Bottom fuel test element is shown in Fig. 1-1. Because of the enormous quantity of metrology data available from the PIE of these 20 elements, it became obvious early in the evaluation stage that data reduction methods which employ the computer had to be developed before this information could be utilized to accomplish the objectives mentioned above. The STAT, STRAIN, GAPS, and DRWDIM computer codes were written to satisfy this need. These codes employ the statistical methods described in Ref. 1 * to reduce fuel test element metrology data and to compare material strains and fuel rod - fuel hole heat transfer gaps computed from this information with predictions obtained using the TREVER (Ref. 2) computer code. The flow of information through these codes is illustrated in Fig. 1-2. Each code has been validated through comparison of sample problem results with the corresponding results obtained from hand calculations.

*

The following difference between the algorithm described for the combined random error in Ref. 1 and the algorithm used in these codes should be noted. In Ref. 1, the precision of the measurement is defined as the lower limit for the sample random error and is accounted for in the combined random error equation by the term for the sample random error. In the computer codes, both a precision term and a sample random error term are included in the combined random error equations. Therefore, by definition, both algorithms agree at the lower limit. When the sample random error term is large, the precision term becomes insignificant in the computer code algorithm. 


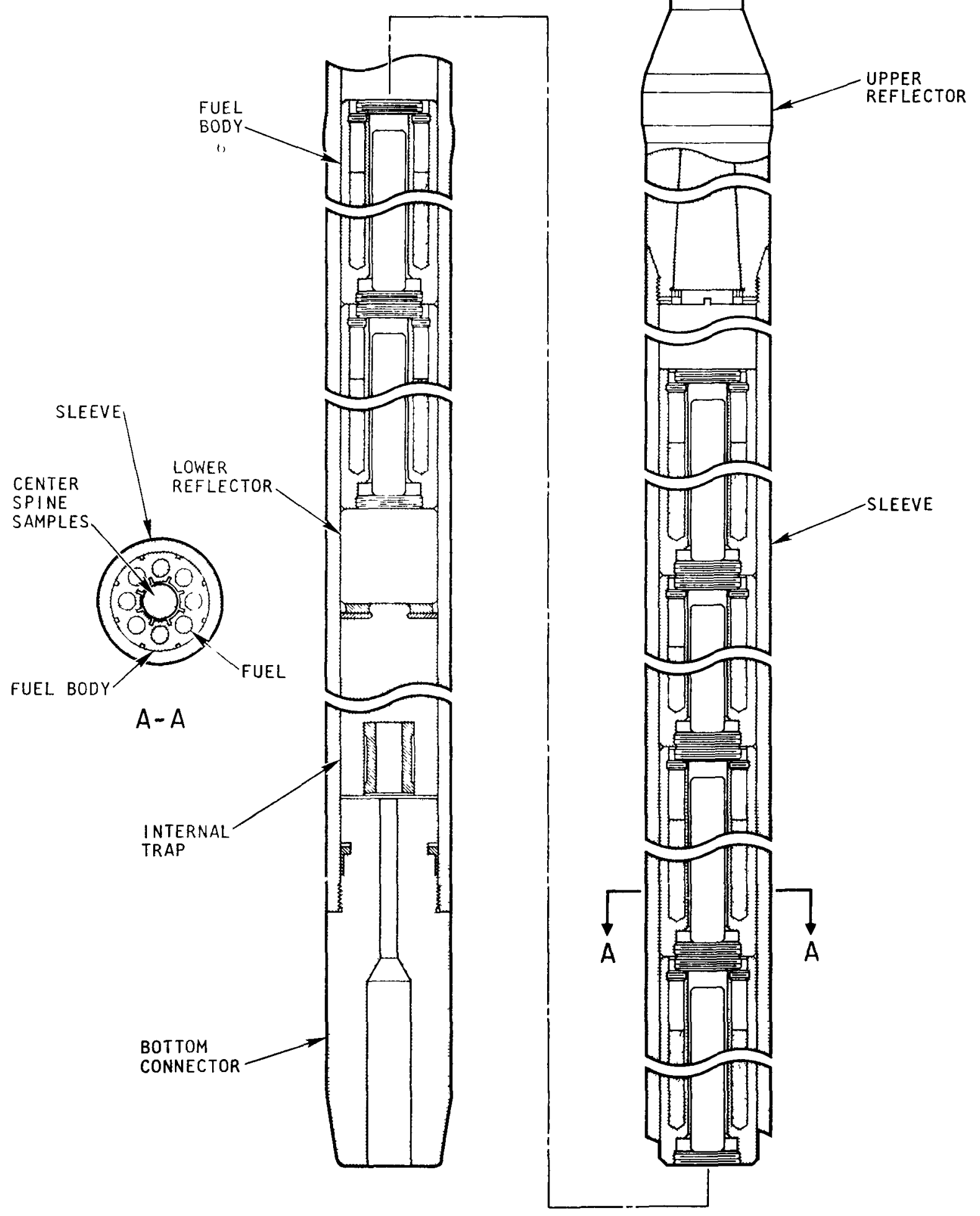

Fig. 1-1. Fuel test element assembly 


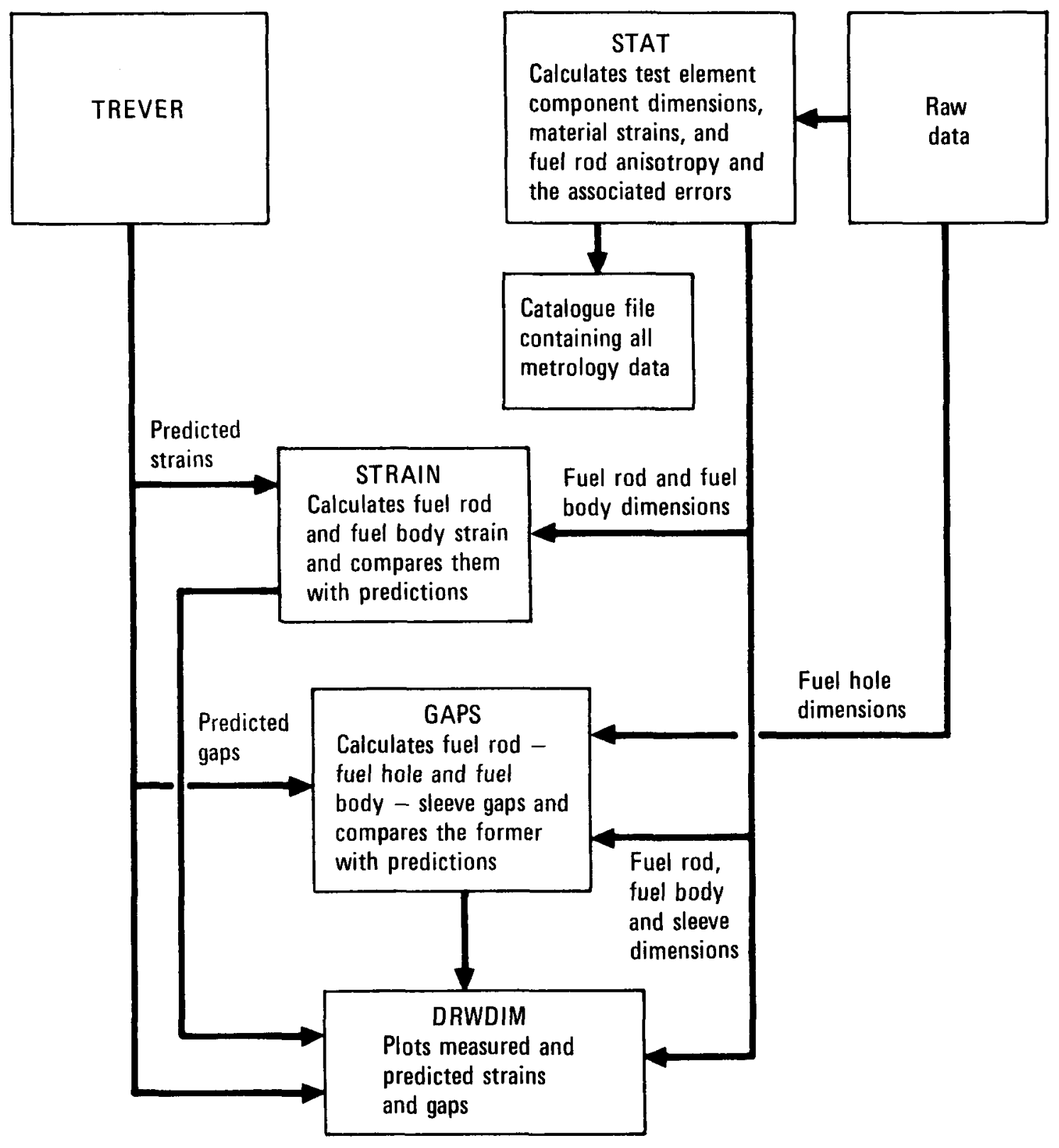

Fig. 1-2. Flow of information through data reduction system 
This system of codes provides the means to organize and permanently store metrology data and to document the results for each analyzed test element. STAT creates data files containing the metrology data for each test element which, when transferred to magnetic tapes, provide a permanent record of all available fuel test element metrology data. The output from these codes is in the form of tables and figures which, along with. other test element information, are included in a data package to be assembled for each analyzed test element. 


\section{STAT}

In March 1976, the Fuel Test Element Activity (FTEA), realizing the need for a computer program to statistically reduce Peach Bottom fuel test element metrology data, arranged for the Computer Services Department (CSD) to write STAT, a code designed to perform this task. STAT, completed in May, was written by R. F. Korts (Ref. 3) to specifications supplied by J. J. Saurwein of FTEA. This code has since undergone numerous modifications to maintain consistency with the statistical methods employed by FTEA and to optimize it with regard to the needs of Peach Bottom test element metrology data reduction. CSD custodial responsibility for STAT is currently assigned to J. E. Gratteau. Input instructions and a sample problem are given in Appendix A and Appendix B, respectively.

\subsection{CALCULATIONS}

The calculations performed by STAT are as follows:

Group I: Total element length and fuel body weight calculations Total element length calculations Fuel body weight calculations

Group II: Fuel rod calculations

Individual fuel rod calculations

Fuel stack average fuel rod calculations

Arbitrarily defined stratum average fuel rod calculations

Element average fuel rod calculations

Group III: Fuel body calculations

Calculations based on fuel body diameter measurements at given locations along the fuel bodies

Fuel body length and average diameter calculations

Element average fuel body calculations 


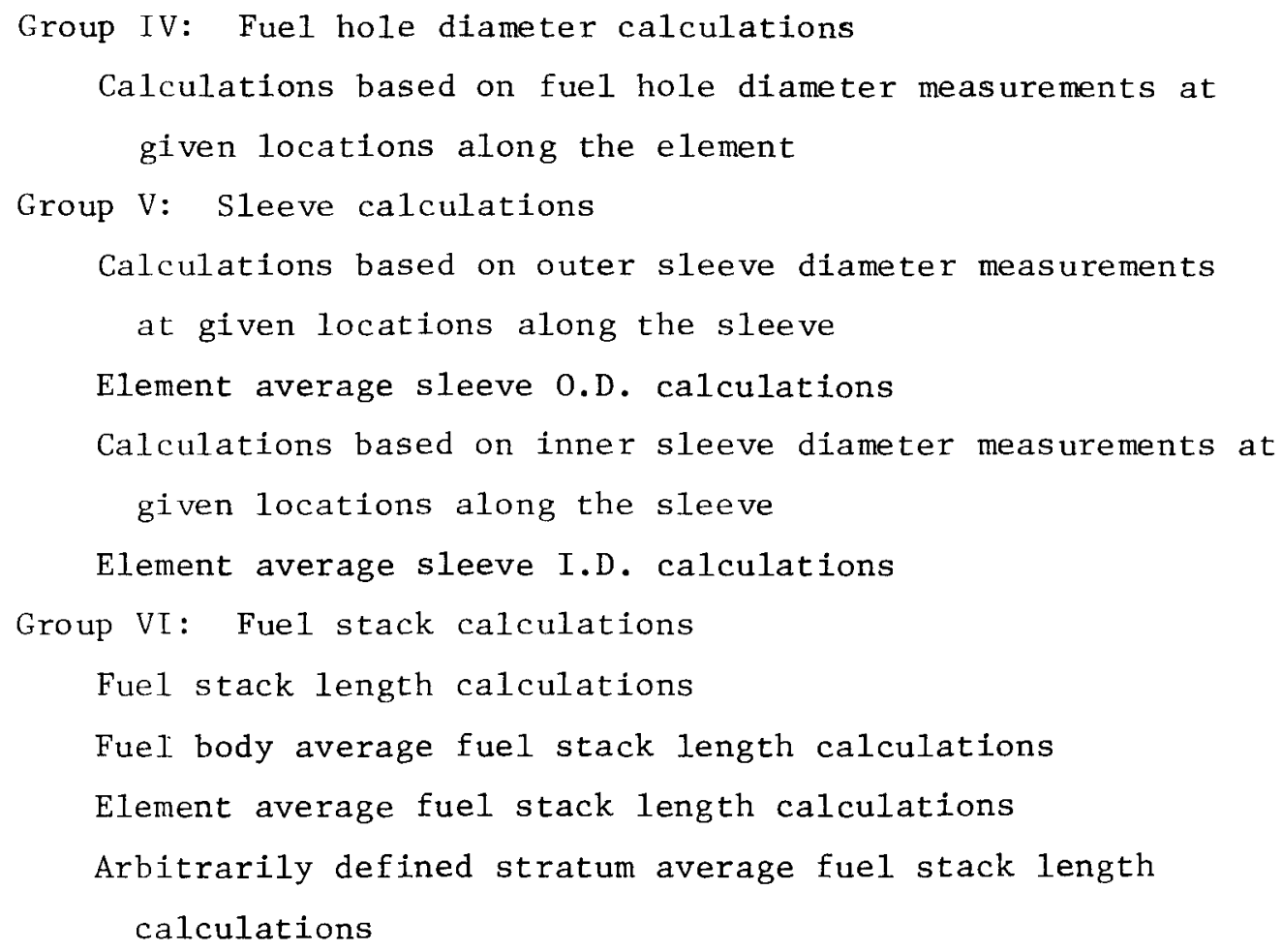

Whether or not the calculations in each of these six groups will be performed during a given STAT run is optional. After checking the options specified via input, STAT will either bypass or execute each group of calculations. With the exception of VI, which requires fuel body length information computed in III, the calculations in each group are completely independent of one another.

A feeling for the scope of the calculations performed by STAT and the type of information provided by them can be obtained from the results of the sample problem given in Appendix B. It is suggested that the reader use this sample problem as an illustration of the text.

A summary of the basic calculations performed by STAT is given in Table 2-1. The equations given in this table are used for all STAT calculations except those which determine stratum average dimensions and sample random errors. A stratum consists of two or more entities having similar properties which can logically be grouped together, such as fuel rods from the same fuel stack, fuel body diameter measurement locations within the 
TABLE 2-1

BASIC CALCULATIONS PERFORMED BY STAT

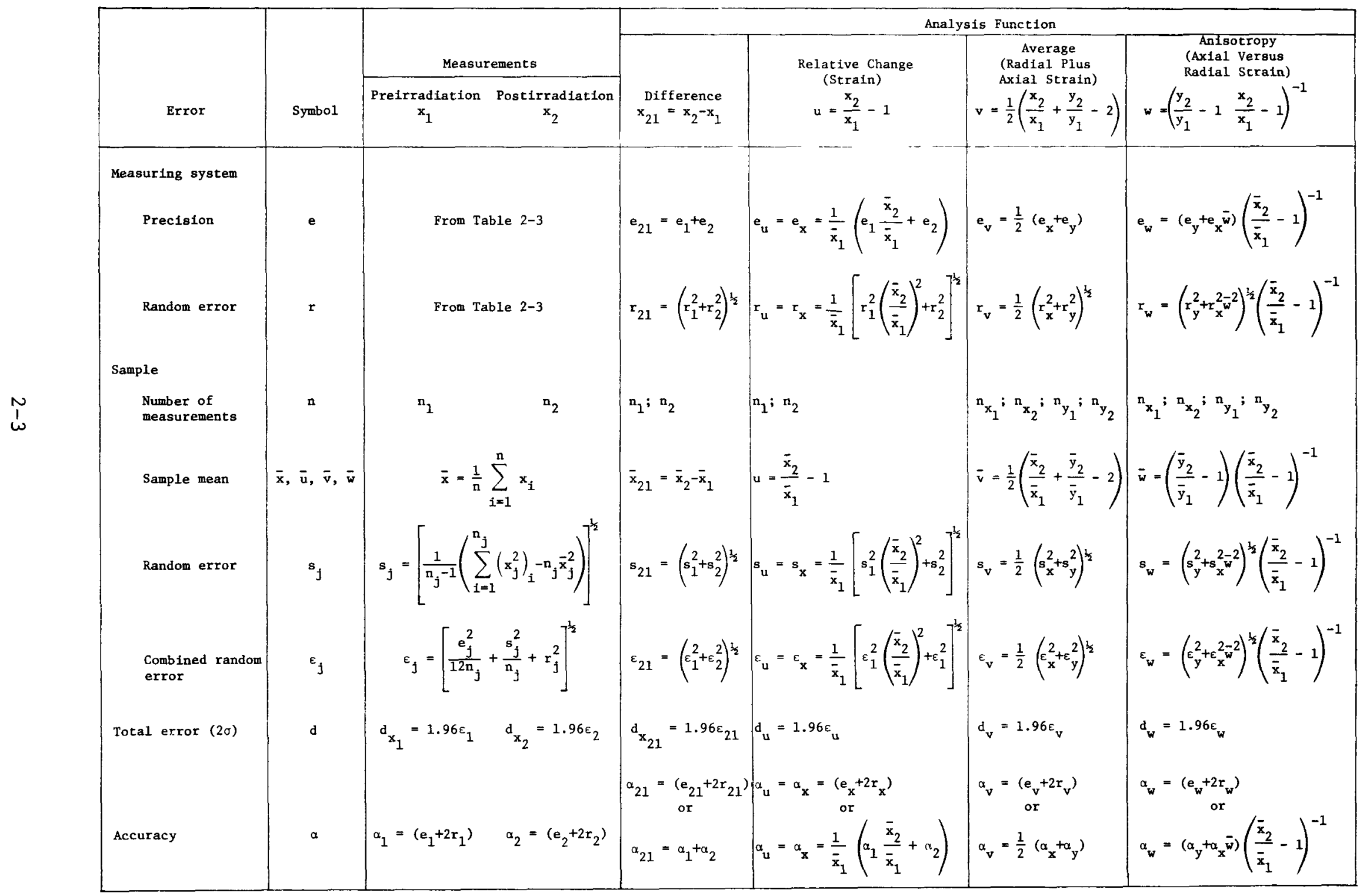


same fuel body, all the fuel stacks in a fuel element, etc. The equations for these calculations are given in Table 2-2. As can be seen, there are two different equations for calculating stratum average sample random errors. Equation $2 \mathrm{a}$ is the more correct statistical statement and is used whenever the number of measurements associated with each sample random error being stratified is equal to or greater than two. If the number of measurements associated with any of the sample random errors being stratified is equal to one, Eq. $2 \mathrm{~b}$ is used.

The information required before a given set of calculations can be performed by STAT includes sample measurements (i.e., preirradiation and postirradiation lengths and diameters) and the errors associated with these measurements. Errors associated with the Peach Bottom fuel test element metrology are tabulated in Table 2-3. The sample random errors listed in this table are "default" values which STAT assigns to a given sample if there are insufficient measurements (less than two) to allow the code to calculate a true sample random error. With the exception of the preirradiation sleeve diameter errors, which were obtained from measurements on an archive sample (Ref. 4), all sample random errors given in Table 2-3 were calculated from test element metrology data.

"Default" sample random errors for all fuel rod dimensions and for the fuel body diameter are calculated by STAT using Eq. 3 of Table 2-2. Errors for the remaining test element parameters are calculated by hand from STAT code results using the same equation. The errors associated with the metrology of each analyzed Peach Bottom fuel test element are compiled in tables (one per element) and a summary table giving the errors associated with the collective metrology of all analyzed elements is maintained. This summary table provides the errors which are used for the analysis of each test element. Upon completion of the analysis of an element, the table is updated to incorporate the new information. The default sample random errors contained in the summary table are calculated from the default errors for the individual test elements using the equation 
Key to Symbols

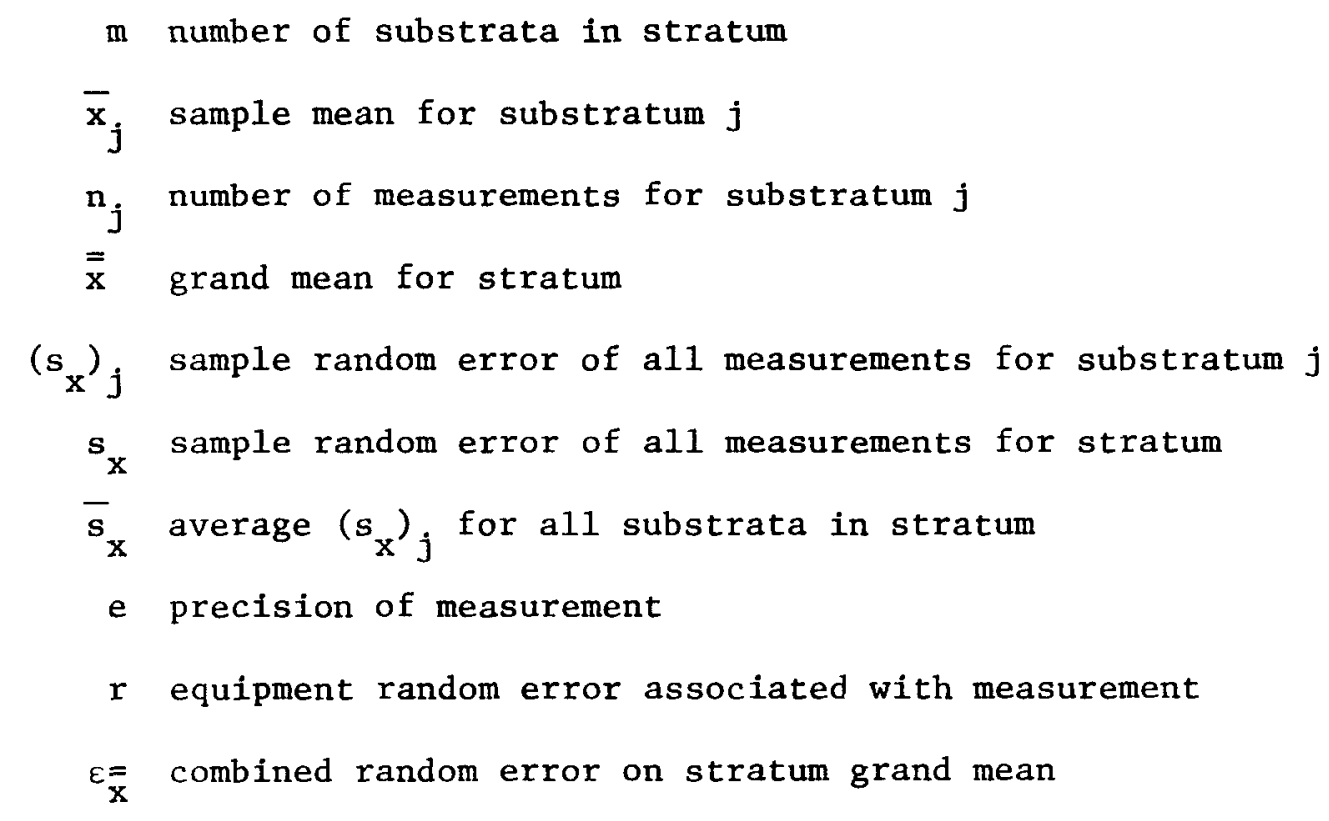

1. Stratum Grand Mean

$$
\overline{\bar{x}}=\frac{1}{\sum_{j-1}^{m} n_{j}} \sum_{j=1}^{m} n_{j} \bar{x}_{j}
$$

2. Sample Random Error of all Measurements for Stratum

a. If $a 11 \mathrm{n}_{j}>1$

$$
s_{x}=\left\{\frac{1}{\left(\sum_{j=1}^{m} n_{j}\right)-1}\left[\sum_{j=1}^{m}\left(n_{j}-1\right)\left(s_{x}\right)_{j}^{2}+\sum_{j=1}^{m} n_{j}\left(\bar{x}_{j}-\bar{x}\right)^{2}\right]\right\}^{1 / 2}
$$

b. If any $n_{j}=1$

$$
s_{x}=\left\{\frac{1}{m}\left[\sum_{j=1}^{m}\left(s_{x}\right)_{j}^{2}+\sum\left(\bar{x}_{j}-\bar{x}\right)^{2}\right]\right\}^{1 / 2}
$$


TABLE 2-2 Cont.

3. Average $\left(s_{x}\right)_{j}$ for all Substrata in Stratum

$$
\bar{s}_{x}=\left[\frac{\sum_{j=1}^{m}\left(s_{x}\right)_{j}^{2}}{m}\right]^{\frac{1}{2}}
$$

4. Combined Rardom Error on Grand Mean

$$
\varepsilon_{\overline{\bar{x}}}=\left(\frac{e^{2}}{12 \sum_{j=1}^{m} n_{j}}+\frac{s_{x}^{2}}{\sum_{j=1}^{m} n_{j}}+r^{2}\right)^{\frac{1}{2}}
$$


TABLE 2-3

ERRORS ASSOCIATED WITH PEACH BOTTOM FUEL TEST ELEMENT METROLOGY

\begin{tabular}{|c|c|c|c|c|c|c|c|c|c|c|c|c|}
\hline & Symbol & $\begin{array}{l}\text { Fuel Rod } \\
\text { Diameter } \\
\text { (in.) }\end{array}$ & $\begin{array}{l}\text { Fuel Rod } \\
\text { Length } \\
\text { (in.) }\end{array}$ & $\begin{array}{l}\text { Fuel Hole } \\
\text { D1ameter } \\
\text { (in.) }\end{array}$ & $\begin{array}{l}\text { Fuel Body } \\
\text { o. D. } \\
\text { (in.) }\end{array}$ & $\begin{array}{l}\text { Fuel Body } \\
\text { Length } \\
\text { (in.) }\end{array}$ & $\begin{array}{l}\text { Sleeve } \\
\text { I.D. } \\
\text { (in.) }\end{array}$ & $\begin{array}{l}\text { Sleeve } \\
\text { O.D. } \\
\text { (in.) }\end{array}$ & $\begin{array}{l}\text { Fuel Stack } \\
\text { Length } \\
\text { (1n.) }\end{array}$ & $\begin{array}{l}\text { Plenum } \\
\text { Length } \\
\text { (1n.) }\end{array}$ & $\begin{array}{l}\text { Element } \\
\text { Length } \\
\text { (1n.) }\end{array}$ & $\begin{array}{l}\text { Fuel Body } \\
\text { We1ght }\end{array}$ \\
\hline $\begin{array}{l}\text { Prefrradiation } \\
\text { nominal value }\end{array}$ & $x_{1}, y_{1}, g_{1}$ & (a) & (a) & (a) & (a) & (a) & $2.7522^{(b)}$ & $3.4868^{(b)}$ & (a) & (a) & 144.0 & (a) \\
\hline Precision & $\begin{array}{ll}\text { Pre: } & e_{1} \\
\text { Post: } & e_{2}\end{array}$ & $\begin{array}{l} \pm 0.0001 \\
\pm 0.0001\end{array}$ & $\begin{array}{l} \pm 0.0001 \\
\pm 0.0001\end{array}$ & $\begin{array}{l} \pm 0.0002 \\
\pm 0.0002\end{array}$ & $\begin{array}{l} \pm 0.0003 \\
\pm 0.0003\end{array}$ & $\begin{array}{l} \pm 0.0006 \\
\pm 0.0006\end{array}$ & $\begin{array}{l} \pm 0.0002 \\
\pm 0.0003\end{array}$ & $\begin{array}{l} \pm 0.0002 \\
\pm 0.0003\end{array}$ & $\begin{array}{l} \pm 0.006 \\
\pm 0.0006\end{array}$ & $\begin{array}{l} \pm 0.0003 \\
\pm 0.0003\end{array}$ & $\begin{array}{l} \pm 0.01125 \\
\pm 0.01125\end{array}$ & $\overline{-}$ \\
\hline $\begin{array}{l}\text { Equipment } \\
\text { random error }\end{array}$ & $\begin{array}{ll}\text { Pre: } & \mathbf{r}_{1} \\
\text { Post: } & \mathbf{r}_{2}\end{array}$ & $\begin{array}{l} \pm 0.0006 \\
\pm 0.0001\end{array}$ & $\begin{array}{l} \pm 0.0001 \\
\pm 0.0001\end{array}$ & $\begin{array}{l} \pm 0.00015 \\
\pm 0.00015\end{array}$ & $\begin{array}{l} \pm 0.00035 \\
\pm 0.00035\end{array}$ & $\begin{array}{l} \pm 0.002 \\
\pm 0.002\end{array}$ & $\begin{array}{l} \pm 0.00015 \\
\pm 0.00015\end{array}$ & $\begin{array}{l} \pm 0.00015 \\
\pm 0.00035\end{array}$ & $\begin{array}{l} \pm 0.007 \\
\pm 0.002\end{array}$ & $\begin{array}{l} \pm 0.00035 \\
\pm 0.00035\end{array}$ & $\begin{array}{l} \pm 0.01 \\
\pm 0.01\end{array}$ & I- \\
\hline Accuracy & $\begin{array}{ll}\text { Pre: } & \alpha_{1} \\
\text { Post: } & \alpha_{2}\end{array}$ & $\begin{array}{l}(c) \\
(c)\end{array}$ & $\begin{array}{l}(c) \\
(c)\end{array}$ & $\begin{array}{l}\text { (c) } \\
\text { (c) }\end{array}$ & $\begin{array}{l}(c) \\
(c)\end{array}$ & $\begin{array}{l}\text { (c) } \\
\text { (c) }\end{array}$ & $\begin{array}{l}\text { (c) } \\
\text { (c) }\end{array}$ & $\begin{array}{l}\text { (c) } \\
(c)\end{array}$ & $\begin{array}{l}\text { (c) } \\
\text { (c) }\end{array}$ & $\begin{array}{l}\text { (c) } \\
\text { (c) }\end{array}$ & $\begin{array}{l}\text { (c) } \\
\text { (c) }\end{array}$ & $\begin{array}{l}1.0 \\
1.0\end{array}$ \\
\hline $\begin{array}{l}\text { Sample random } \\
\text { error on } \\
\text { measurement }(1 \sigma)\end{array}$ & $\begin{array}{ll}\text { Pre: } & \mathbf{s}_{\mathbf{x}_{1}} \\
\text { Post: } & \mathbf{s}_{\mathbf{x}_{2}}\end{array}$ & $\begin{array}{l} \pm 0.0007 \text { (d) } \\
\pm 0.0015 \text { (d) }\end{array}$ & $\begin{array}{l} \pm 0.0019^{(\mathrm{e})} \\
\pm 0.0019^{(\mathrm{f})}\end{array}$ & $\begin{array}{l} \pm 0.0001 \\
\pm 0.0004\end{array}$ & $\begin{array}{c}0.0 \\
\pm 0.0013\end{array}$ & $\begin{array}{l} \pm 0.0071 \text { (e) } \\
\pm 0.0071 \text { (d) }\end{array}$ & $\begin{array}{l} \pm 0.0008^{(b)} \\
\pm 0.0005^{(f)}\end{array}$ & $\begin{array}{l} \pm 0.0007 \text { (b) } \\
\pm 0.0006^{(f)}\end{array}$ & $\begin{array}{l}\text { (c) } \\
\text { (c) }\end{array}$ & $\begin{array}{l}\text { (c) } \\
\text { (c) }\end{array}$ & $\begin{array}{l}\text { (c) } \\
\text { (c) }\end{array}$ & $\begin{array}{l}\text { (c) } \\
\text { (c) }\end{array}$ \\
\hline
\end{tabular}

(a) Check appropriate drawing.

(b) Determine from measurements on archive sample.

(c) Not required by STAT.

(d) Based on FTE-3, -4, and -6 metrology data.

(e) Postirradiation information used in absence of prefrradiation data.

(f) Based on FTE-4 metrology data. 


$$
\overline{\bar{s}}_{u}=\left[\frac{1}{\sum_{j=1}^{m} n_{j}} \sum_{j=1}^{m} n_{j}\left(\vec{s}_{u}\right)_{j}^{2}\right]^{1 / 2}
$$

where

$$
\begin{aligned}
\mathrm{m} & =\text { total number of test elements, } \\
\mathrm{n} & =\text { number of } \mathrm{s}_{\mathrm{u}} \text { on which }\left(\overline{\mathrm{S}}_{\mathrm{u}}\right)_{\mathrm{j}} \text { is based, } \\
\left(\mathrm{S}_{\mathrm{u}}\right)_{j} & =\text { default sample random error for fuel test element } \mathrm{j} .
\end{aligned}
$$

Table 2-3 contains the errors associated with the collective metrology of FTEs 3, 4, and 6 which constitute the test elements analyzed to date.

Comments which should help explain the calculations performed by the code are given below.

\subsubsection{Total Element Length and Fuel Body Weight Calculations (Group I)}

These calculations, being very elementary and straightforward, do not require comment.

\subsubsection{Fuel Rod Calculations (Group II)}

Individual fuel rod calculations will be performed only for fuel rods having postirradiation diameter measurements.

If a fuel rod has postirradiation diameter but no postirradiation length measurements, all calculations requiring length information will be omitted. When stratifying such a rod with other rods within a stratum, the rod will only be included in diameter-related stratification calculations.

The strata in group II are individual fuel stacks, arbitrarily defined groups of fuel stacks, and the entire test element (all fuel stacks).

Stratum average calculations will be performed only for strata which include at least one fuel rod having postirradiation diameter measurements. 
A stratum containing all fuel rods having postirradiation diameter but no postirradiation length measurements will be treated in the same manner as a fuel rod having only diameter data (see comment above on fuel rods with no length measurements).

Equation $2 a$ of Table 2-2 is always used when stratifying fuel stack average fuel rod sample random errors. The loss of fuel stack average sample random error information, should the number of measurements associated with a stack average sample random error be equal to 1 (which is very unlikely), is avoided by setting the value for this number of measurements equal to 2. Although somewhat arbitrary, this should guarantee that each fuel stack receives nearly the proper weighting.

\subsubsection{Fue1 Body Ca1culations (Group III)}

When no preirradiation fuel body diameter data are available at axial locations at which postirradiation diameter measurements were taken, STAT scans the available data and assigns the preirradiation diameter at the nearest axial location (within the same fuel body) to the location being considered. If no preirradiation diameter data are input for a fuel body having postirradiation diameter measurements, STAT will terminate execution by calling the MERR subroutine. If no postirradiation fuel body diameter measurements are available, none of the calculations in this group will be performed.

When performing calculations at fuel body diameter measurement locations or stratifying these locations to obtain average fuel body diameter information, only axial locations at which postirradiation diameter measurements were taken will be considered.

If a fuel body has postirradiation diameter but no postirradiation length measurements, a11 calculations requiring length information will be omitted. When stratifying such a fuel body with other fuel bodies in a test element, the body will be included only in the diameter-related stratification calculations. 
A fuel body having no postirradiation diameter data will not be included in any stratification calculations.

As an exception to the general rule concerning the use of Eq. $2 b$ of Table 2-2, Eq. 2a of Table 2-2 is always used when stratifying fuel body average fuel body diameter sample random errors. If the number of measurements associated with a sample random error being stratified is equal to 1 , it is arbitrarily set to 2 . The criteria described in Section 2.1 concerning the use of Eq. $2 \mathrm{a}$ or Eq. $2 \mathrm{~b}$ of Table 2-2 in stratifying sample random errors are used to determine which equation to use in stratifying fuel body lengths.

If there are no postirradiation length measurements available for any fuel bodies within an element, all total element average fuel body calculations requiring fuel body length information will be omitted.

\subsubsection{Fue1 Hole Diameter Calculations (Group IV)}

Only calculations at individual measurement locations are performed in this group. No stratification calculations are included.

Calculations at a given measurement location are performed only if both preirradiation and postirradiation fuel hole diameter information has been supplied for that location.

\subsubsection{Sleeve Calculations (Group V)}

The calculations based on the sleeve I.D. and the sleeve O.D. are identical. They are also completely independent so that sleeve I.D. calculations can be performed even if there is no sleeve O.D. information and vice versa.

When performing calculations at sleeve diameter measurement locations or stratifying these locations to obtain test element average sleeve diameter 
information, only the locations at which postirradiation diameter measurements were taken will be considered. If no postirradiation diameter measurements were taken, no calculations will be performed.

\subsubsection{Fue1 Stack Calculations (Group VI)}

Although the individual fuel stack calculations are quite elementary, they can be very confusing with respect to what data should be used as input. The potential for confusion is a result of the different ways in which the fuel stack length can be obtained. There are three possible methods: (1) summing up the lengths of the component fuel rods, (2) measuring the total length of the component rods when laid end to end, and (3) measuring the fuel hole depth and subtracting the fuel hole plenum and compact pusher lengths. If method 1 is used, the result is an "accumulated" stack length. Method 2 yields a "composite" stack length, and an "indirect composite" stack length is provided by method 3 . The preferred input for these calculations is composite or indirect composite preirradiation stack lengths and accumulated postirradiation stack lengths. Inputting accumulated preirradiation and composite postirradiation stack lengths is also acceptable.

Calculations for individual fuel stacks are performed if a preirradiation stack length and postirradiation fuel hole plenum length are provided. Otherwise the fuel stack will be skipped. These data enable STAT to perform the indirect fuel stack length calculations (assuming that fuel body length data are available and the group III calculations were executed). If no postirradiation stack length is available, the stack will still be considered but the direct stack length calculations will not be performed. When stratifying these fuel stacks to obtain stratum average fuel stack lengths and associated errors, each fuel stack will be considered only when stratifying parameters which are available for that stack. 
The first $\mathrm{N}$ strata for which stratum average fuel stack calculations are performed are the $\mathrm{N}$ fuel bodies of the fuel test element. These $\mathrm{N}$ strata are then stratified to obtain total element average fuel stack information. If there are no fuel stack data for a given fuel body, it will not be included in these stratification calculations.

\subsection{STRUCTURE}

The STAT program logic consists of a rather simple main program called MAIN which invokes a series of subroutines, the first of which reads and validates the input and the remainder of which perform the calculations and print the results. A listing of these subroutines and their functions is given below.

Subroutine

AERF

AMEAN

BASIC

BDYSAV

DIFANL

G2STAT

INPUT

LODS TK

LSTAT

\section{Function}

Computes combined random errors $\left(\varepsilon_{j}\right.$ as

Computes sample means ( $\mathrm{X}$ as defined in Table 2-1).

Computes stratum average fuel and fuel hole plenum lengths and the associated errors for group VI strata.

Saves fuel body statistical data calculated in group III for use in group VI calculations.

Computes the "analysis functions" and errors given in Table 2-1.

Collects and stratifies fuel body length statistics for use in group VI stratum average calculations.

Reads and validates input and creates a data file.

Stores fuel stack average fuel rod data into printing arrays.

Computes total element average fuel stack and fuel hole plenum lengths and the associated errors. 
Sub routine

PARCOM

PRINT8

SLVSTR

STDEV

STRAT

STRAT8

SUMS

SVSTCK

TABLE4

TABLE5

TABLE6

TAB5A

TB4PRT

TB5PRT

TB 7PRT

TEDATA

TELEMT

\section{Function}

PDP element defining parameters used to set array sizes and common blocks T4DATA and GENERL.

Does elementary group VI fuel stack length calculations and prints all group VI results.

Performs all group V calculations.

Computes sample random errors $\left(S_{j}\right.$ as defined in
Table $2-1)$.

Combines fuel rods into strata and initiates stratum average fuel rod calculations and printing of results.

Combines fuel stacks into strata and initiates group VI stratum average fuel stack calculations and printing of results.

Stratifies individual fuel rods to obtain fuel stack average fuel rod information.

Saves fuel stack average fuel rod statistical data.

Prepares and computes (via subroutines) individual fuel rod and stack average fuel rod data.

Prepares and computes (via subroutines) fuel body data at individual measurement locations and average fuel body data.

Assembles average fuel body data and computes (via subroutine) and prints element average fuel body data.

Performs (via subroutine) all group IV calculations.

Prints a11 group II results.

Prints all group III (excluding element average fuel body results) and group IV results.

Prints a11 group $\mathrm{V}$ results.

Performs group I calculations and prints results.

Assembles fuel stack average fuel rod data and performs (via subroutines) element average fuel rod calculations. 
Sub routine

TS TRAT

T8CALC
Function

Employs the equations of Table 2-2 to calculate stratum average dimensions and sample random errors. Performs all stratification calculations except for those performed in SUMS and LSTAT.

Performs (via subroutines and internal equations) all group VI stratum average calculations.

\section{3 PROGRAM LIMITS}

As currently dimensioned, STAT requires approximately 60K words of memory. The dimensions of the arrays used in the program are specified by various parameters defined in the PDP element, PARCOM. These parameters and their specified values are listed below.

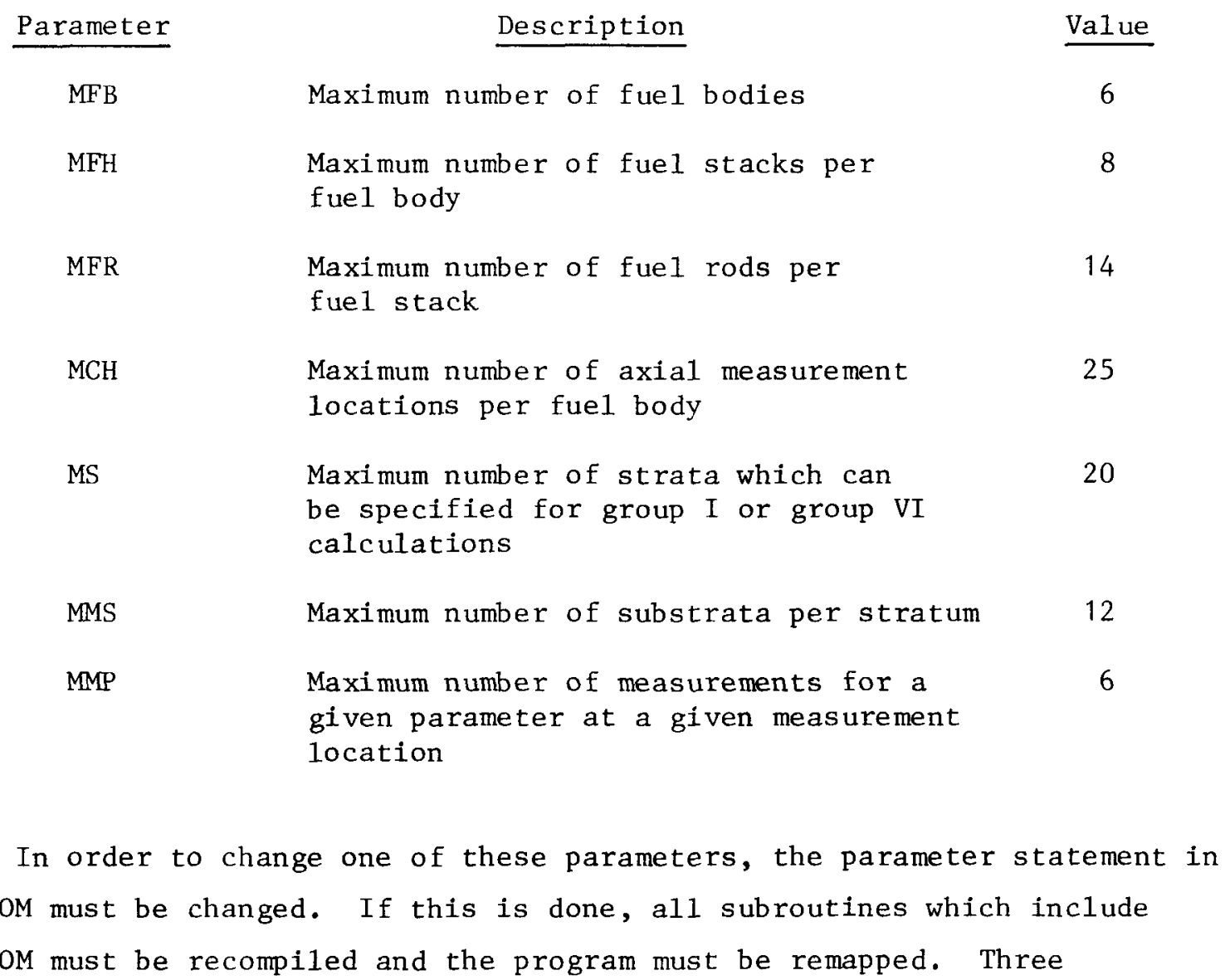


subroutines, STRATS, SUMS, and TELEMT, do not include PARCOM but contain parameter statements specifying these parameters. These statements must also be changed. Since the memory required by STAT is already near the $65 \mathrm{~K}$ limit, the effect of any parameter change should be estimated before revising the code in order to avoid exceeding this limit.

\subsection{INPUT}

Before STAT can be run, all available metrology data for the test element to be analyzed must be put on computer cards. Instructions for assembling this card deck are given in Appendix A. The first time STAT is run for a given element, a catalogued file, which will serve as the input for subsequent STAT runs, is created from the data deck. This catalogued file will then be copied onto a magnetic tape (see Section 2.6) which will provide a permanent record of the data.

The user must examine the metrology data for the test element being analyzed to ascertain whether the data required by each of the six groups of STAT calculations are available (see Sections 2.1.1 and 2.1.6). If not, STAT must be instructed via the option card in the input data deck to bypass the calculations for which there are insufficient data. On the other hand, if the available metrology data exceed any of the STAT code limits (Section 2.3), these limits must be adjusted, if possible, in order for all the data to be processed. Otherwise STAT will load all the excessive data into the last available space in the involved arrays such that all excessive data except the last set are lost. When this is done, the code prints an error message indicating which limit has been exceeded and the numbers of the cards on which the excessive data were given. This procedure has proven to be a valuable means of identifying certain keypunch errors in the data deck as well as a check on the quantity of data being supplied. It should be noted, however, that the code will not detect all keypunch errors in the data deck, so it is important that users validate their input. 
Whenever postirradiation data are supplied to the code, the STAT ca1culations will assume that preirradiation data are also available. Therefore, preirradiation data must be supplied whenever postirradiation data are available. If no preirradiation measurements were made, the nomina1 value for the parameter must be assigned and assumed to be one measurement.

In the INPUT subroutine, STAT adds 0.003 in. to each preirradiation fuel rod diameter if instructed to do so via input. This is done to account for the statistically determined discrepancy between measurements made with an air gauge and with a micrometer (see Ref. 5). Since preirradiation fuel rod diameters were generally measured with an air gauge and postirradiation fuel rod diameters were always measured with a micrometer, this correction is necessary if valid fuel rod radial strains are to be obtained. It is up to the user to ascertain the measuring technique used to obtain preirradiation fuel rod diameters for each test element and to specify whether or not this correction should be made.

The errors associated with Peach Bottom fuel test element metrology required by STAT (Table 2-3) are defined within the program by DATA or equivalence statements. The subroutines including these statements are listed below.

\section{Parameter}

Fue 1 rod length and diameter

Fuel body diameter

Fuel body diameter

Fuel body length

Fue1 hole diameter

Sleeve I.D. and O.D.

Fue1 element 1ength

Fuel body weight
Errors

A11

Sample random error TABLE5

Precision and equip- MAIN \& G2STAT ment random error

A11

A11

A11

Accuracy

Accuracy
Subroutine

TABLE4

TABLE5

TAD5A

SLVSTR

TEDATA

TEDATA 


\section{Parameter}

Fuel stack length

Fuel hole plenum length
Errors

Subroutine

Precision and equip- BASIC

ment random error

Precision and equip- BASIC

ment random error

\subsection{OUTPUT}

STAT prints out all results in tables suitable for inclusion in written reports. In addition to these tables, the code provides punched cards containing fuel rod anisotropy and fuel body and sleeve dimensional data, and a catalogued file (unit 11) containing fuel rod dimensional data. The cards and the catalogued file provide information required by STRAIN, GAPS, and the DRWDIM computer codes.

\subsection{USAGE CONSIDERATIONS}

The source, relocatable, and absolute elements for the STAT code are contained on the first file of tape 5415. The following run streams show three ways of running the program:

1. All input from cards

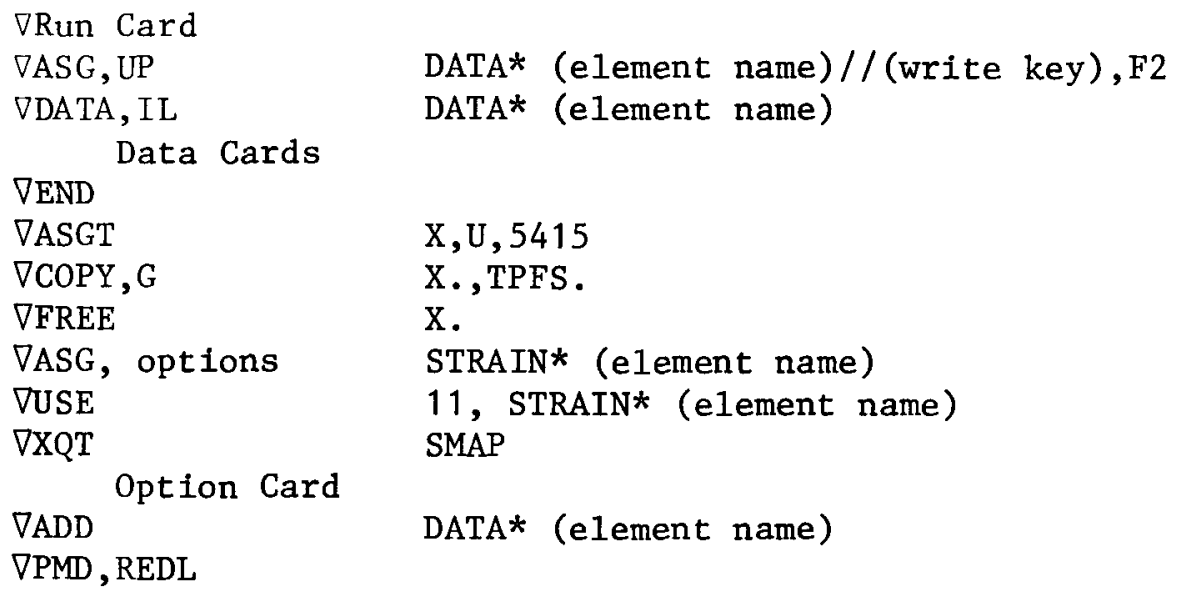


2. Input from previously created file

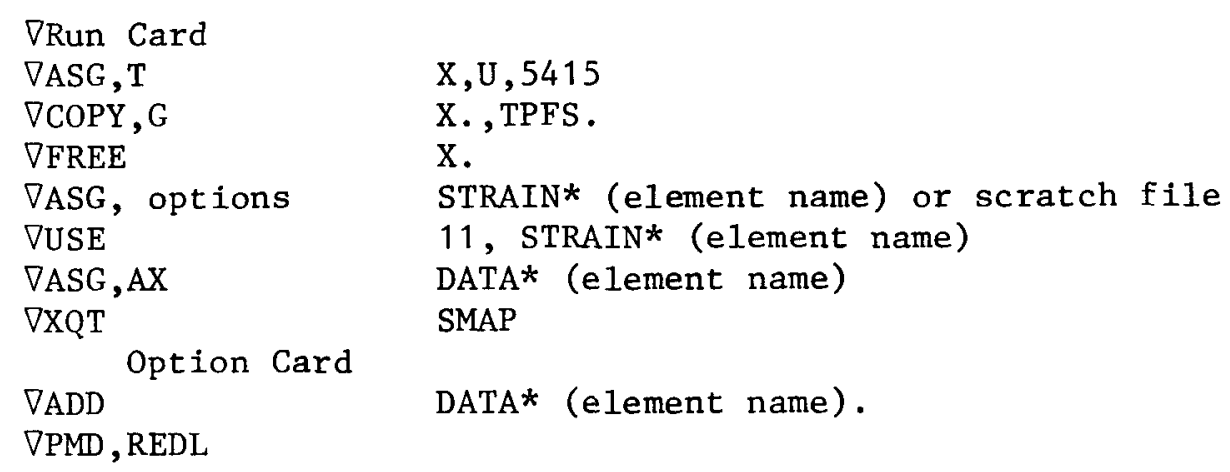

3. Input from previously created file - changes required

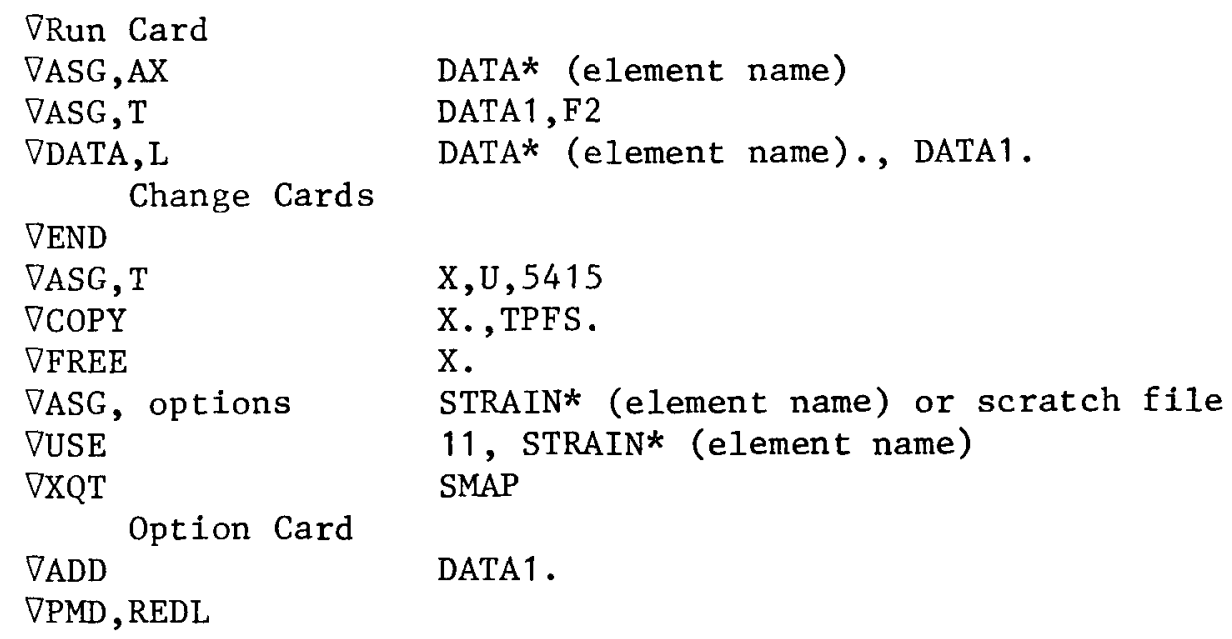

A minimum of 100 pages, a maximum time of 2 minutes, and a maximum of 400 cards should be sufficient for the majority of STAT runs.

After the catalogued file DATA* (element name) has been created by STAT, it should be put on magnetic tape in order to provide a permanent record of the metrology data. The following technique is suggested:

\begin{tabular}{|c|c|c|}
\hline$\nabla A S G, T$ & $\mathrm{X}, \mathrm{U}, \mathrm{SAVE}$ & \\
\hline DSAVTAP & $\mathrm{X}$ & \\
\hline Metrology Data & (element name) & \\
\hline$\nabla \mathrm{ASG}, \mathrm{AX}$ & DATA* (element & name) \\
\hline DCOPY,GM & (element & name)., X. \\
\hline
\end{tabular}


Since these data files are not very large, several of them can be stacked on one tape. In order to use a tape created in this fashion as the input for a STAT run, the appropriate file on the tape must be copied back into a catalogued or temporary fastrand file using the G option. The file is then added as shown in 1 through 3 above. 


\section{STRAIN}

The STRAIN computer code, written in August 1976, generates and compares fuel body and fuel rod strains based on Peach Bottom fuel test element metrology data with the corresponding predicted strains obtained from the TREVER code (Ref. 2) using the methods outlined in Ref. 1.

\subsection{CALCULATIONS}

The calculations performed by STRAIN can be divided into two groups. The calculations in the first group are performed in order to compute and compare the following measured strains with the corresponding predicted strains:

1. The fuel body strain at each fuel body diameter measurement location.

2. The average fue 1 rod strain for each fuel blend or group of fuel blends having similar irradiation-induced strain characteristics at each core height corresponding to the center of a layer of fuel rods.

The second group of calculations stratify group I calculation results in order to compute and compare the following measured and predicted strains:

1. The average fuel rod strain in each fuel body for each fuel blend or group of fuel blends having similar irradiation-induced strain characteristics.

2. The average fuel rod strain in the entire fuel element for each fuel blend or group of fuel blends having similar irradiationinduced strain characteristics. 
3. The average fuel body strain for each fue1 body.

4. The average fuel body strain for the entire fuel element.

\subsubsection{Group I Calculations}

The calculations included in this group are summarized in Table $3-1$. As can be seen, the fuel rod data obtained from STAT must be stratified in order to obtain the average fuel rod dimensions for each fuel blend or group of fuel blends having similar irradiation-induced strain characteristics. The manner in which the fuel rods will be stratified is dictated by the way the fuel stacks were grouped for the TREVER analysis of the test element being considered and is specified via input by assigning a fuel type number to each fuel stack. For each fuel rod layer, the rods in fuel stacks which have been assigned the same fuel type number will be stratified to give average fuel rod dimensional data for that fuel type. For example, if fuel stacks 1 and 2 in fuel body 1 were grouped together for the TREVER analysis, these stacks will be assigned the same fuel type number and the fuel rods in these stacks will be stratified at each fuel rod layer so that measured strains which correspond to the predicted strains calculated by TREVER can be computed.

Because of the way STAT processes fuel rod metrology data (Section 2.1.2), all fuel rods included in the STAT results which serve as input to the STRAIN code have postirradiation diameter information, but not always postirradiation length information. When stratifying fuel rods in order to compute the average preirradiation and postirradition length information required for axial strain calculations, STRAIN considers only the fuel rods having postirradiation length data. As can be seen in Table 3-1, the measured fuel rod strain which is compared with the corresponding predicted strain is the average of the radial and axial fuel rod strains. However, in cases where an axial fuel rod strain cannot be calculated due to an absence of postirradiation fuel rod length information, the measured strain is assumed to equal the radial strain. 
TABLE 3-1

EQUATIONS FOR COMPUTING AND COMPARING FUEL ROD AND FUEL BODY STRAINS

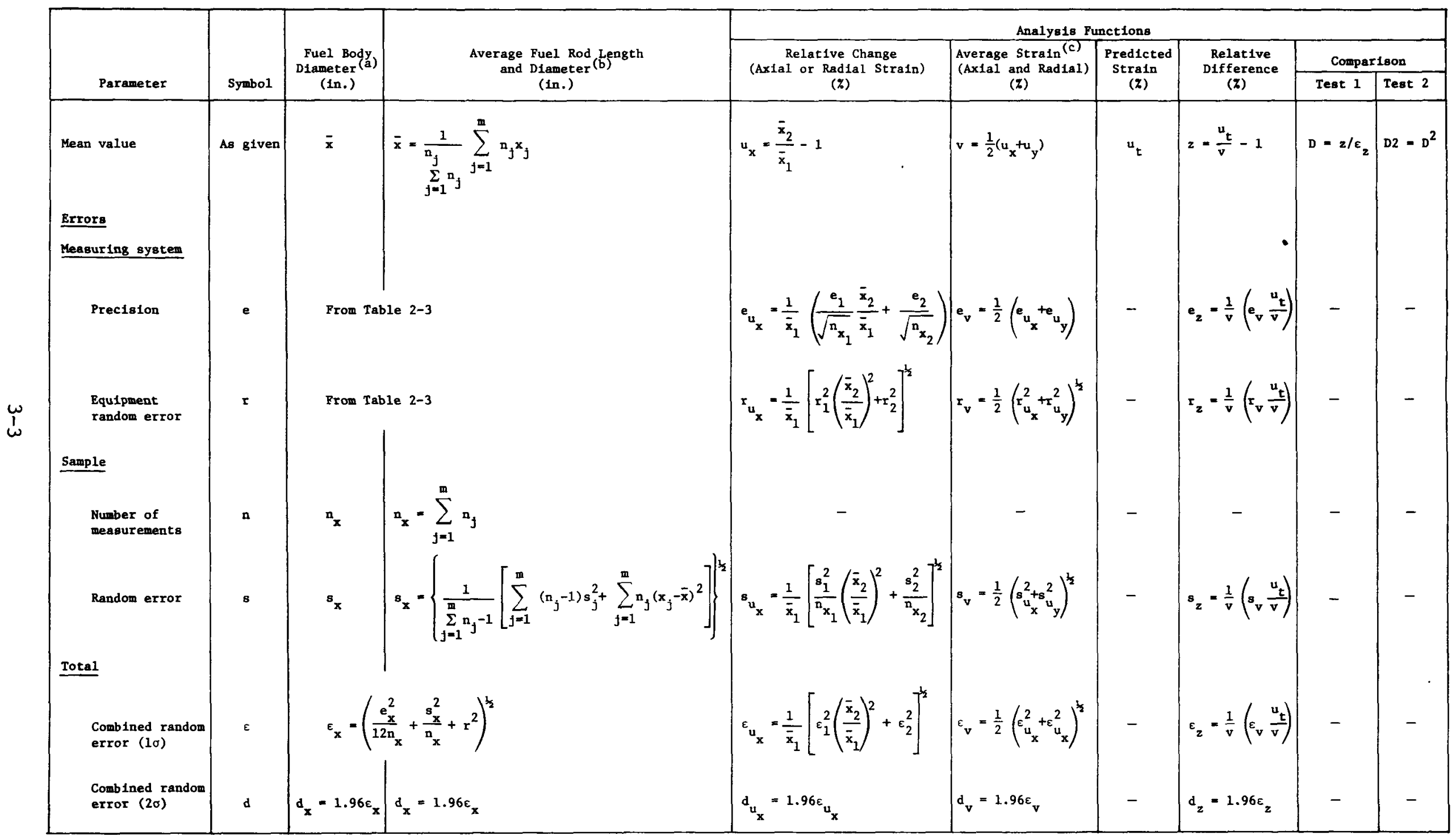

(a) $\bar{x}, n_{x}$, and $s_{x}$ are obtained from STAT results.

${ }^{\text {(c) }}$ For fuel rods only.

(b) $x_{j}, n_{j}$, and $s_{j}$ are obtained from STAT results. 
Since the 30 TREVER calculation points do not correspond to the midpoints of the fuel rod layers, STRAIN interpolates the strains obtained from TREVER in order to determine the predicted strains at the locations at which measured strains have been computed. At the present time, the means for determining the errors associated with predicted strains have yet to be developed, so these errors are assumed to be zero. Consequently, the terms representing these errors have not been included in the equations for the errors associated with the analysis function $Z$ (Table 3-1).

The analysis functions $\mathrm{D}$ and $\mathrm{D} 2$ are statistical tests used to determine the agreement between measured and predicted strains. These tests are discussed in Ref. 1.

\subsubsection{Group 2 Calculations}

The calculations included in this group are summarized in Table 3-2. These calculations are performed in order to provide statistical information to be used in determining the overall agreement between measured and predicted strains within each fuel body and within the entire test element. The statistical tests employed in making these comparisons are discussed in $\operatorname{Ref} .1$.

\subsection{STRUCTURE}

STRAIN consists of a main program, called STRAIN, and a series of short subroutines which perform various calculations. The main program is responsible for reading the input data, performing or calling the subroutines to perform the calculations, and printing the results. The subroutines and their functions are listed below.

Subroutine

AERF

\section{Function}

Calculates combined random errors using Eq. $3 \mathrm{~b}$ of Table 3-2 
TABLE 3-2

EQUATIONS FOR FUEL BODY AVERAGE AND TEST ELEMENT

\section{AVERAGE CALCULATIONS}

Key to Symbols

$m=$ total number of substrata in stratum

$\overline{\bar{a}}=$ stratum average value for a given parameter

$\bar{a}_{j}=$ mean value of a given parameter for substrata $j$.

See Table 3-1 for explanation of a11 other symbols

1. Stratum Means

$$
\overline{\mathrm{a}}=\frac{1}{\mathrm{~m}} \sum_{j=1}^{\mathrm{m}} \mathrm{a}_{j} \quad\left(\mathrm{a}=\mathrm{v}, \mathrm{u}_{\mathrm{t}}, \mathrm{z}, \mathrm{D}, \mathrm{D} 2\right)
$$

2. Root Mean Squares ( $\mathrm{rms}$ )

$$
\mathrm{rms}_{a}=\left[\frac{1}{m} \sum_{j=1}^{m}\left(\bar{a}_{j}-\bar{a}\right)^{2}\right]^{\frac{1}{2}} \quad\left(a=v, u_{t}, z\right)
$$

3. Average Errors on Substrata Means

$$
\begin{aligned}
& \text { a. } \bar{\varepsilon}_{\bar{a}}=\left[\frac{1}{\mathrm{~m}} \sum_{j=1}^{m}\left(\varepsilon_{\overline{\mathrm{a}}}\right)_{j}^{2}\right]^{\frac{1}{2}} \quad\left(\varepsilon_{\mathrm{a}}=\mathrm{s}_{\mathrm{v}}, \mathrm{e}_{\mathrm{v}}, \mathrm{r}_{\mathrm{v}}, \mathrm{s}_{\mathrm{z}}, \mathrm{e}_{\mathrm{z}}, \mathrm{r}_{\mathrm{z}}\right) \\
& \text { b. } \bar{\varepsilon}_{\overline{\mathrm{a}}}=\left[\frac{\bar{e}_{\overline{\mathrm{a}}}^{2}}{12}+\bar{s}_{\overline{\mathrm{a}}}+\overline{\mathrm{r}}_{\overline{\mathrm{a}}}^{2}\right]^{\frac{1}{2}} \quad(\mathrm{a}=\mathrm{v}, \mathrm{z})
\end{aligned}
$$

4. Errors on Stratum Means

$$
\text { a. } s_{\overline{\bar{a}}}=\frac{\bar{s}_{\overline{\mathrm{a}}}}{\sqrt{\mathrm{m}}} \quad(\mathrm{a}=\mathrm{v}, \mathrm{z})
$$




$$
\text { b. } \varepsilon_{\overline{\bar{a}}}=\left[\frac{\overline{\mathrm{e}}_{\overline{\mathrm{a}}}^{2}}{12 \mathrm{~m}}+\frac{\overline{\mathrm{s}}_{\overline{\mathrm{a}}}^{2}}{\mathrm{~m}}+\overline{\mathrm{r}}_{\overline{\mathrm{a}}}^{2}\right]^{\frac{1}{2}} \quad(\mathrm{a}=\mathrm{v}, \mathrm{z})
$$

5. Parameters Required for Statistical Tests

a. Group Agreement Test (Test 1)

$$
\mathrm{T} 1=\sqrt{\mathrm{m}} * \overline{\overline{\mathrm{D}}}
$$

b. Group Goodness of Fit Test (Test 2)

$$
\mathrm{T} 2=\overline{\overline{\mathrm{D} 2}}
$$

These tests are explained in detail in Section 4.1.3.2 of Ref. 1

6. Upper 95 Percentile Point for Chi-squared Distribution with $\mathrm{m}$ Degrees of Freedom. (To be used in Test 2)

$$
x_{0.95}^{2} / m=(1-2 / 9 m+1.645 \sqrt{2 / 9 m})^{3}
$$

This is an approximation only for large m (Ref. 6). A more precise value has to be obtained from statistical tables. 
Subroutine

AMEAN

RMS

STRAT

CALC

CALC1
Function

Computes $\overline{\bar{a}}$ as defined in Table 3-2

Computes RMS ${ }_{a}$ as defined in Table 3-2

Computes all $\bar{E}_{-}$as defined in Table 3-2

Computes average fuel rod dimensions and sample random errors as shown in Table 3-1

Computes the "analysis functions" and their associated errors as shown in Table 3-1

\section{3. PROGRAM LIMITS}

The dimensions of the arrays used in STRAIN are specified by parameters which are defined in STRAIN, CALC, and CALC1. These parameters and their spectfied values are listed below.

Parameter

NB

NS

NR

$\mathrm{NP} \emptyset \mathrm{S}$

NFT
Description

Maximum number of fuel bodies

Maximum number of fuel stacks per fuel body

Maximum number of fuel rods per fuel stack

Maximum number of axial measurement locations per fuel body

Maximum number of fuel blends
Value

$$
6
$$

14

As can be seen seen, all of these parameters with the exception of NFT are common to both STAT and STRAIN. As long as the values for these parameters are at least as large as those specified in STAT, no difficulties should be encountered in STRAIN over the array sizes. The STRAIN code currently requires approximately $20 \mathrm{~K}$ words of memory. 


\subsection{INPUT}

The following input is required by the STRAIN code:

1. A card deck formulated as specified by the input instructions given in Appendix $C$.

2. A TREVER results tape containing predicted strains (unit 15).

3. A STAT results tape or catalogued file containing fuel rod and fuel body diameter data (unit 10).

The precision and equipment random errors associated with Peach Bottom fuel test element metrology are assigned internally via DATA statements in the main program. These errors are identifled below.

Variable Name in Code

$E Y 1, E Y 2, R Y 1$, and RY2

$\operatorname{EX1}(1), \operatorname{EX} 2(1), R X 1(1), R X 2(1)$

$\operatorname{EX} 1(2), \operatorname{EX} 2(2), \operatorname{RX} 1(2), \operatorname{RX} 2(2)$
Description (Notations from Table 2-3)

$e_{1}, e_{2}, r_{1}$, and $r_{2}$ for fuel rod length $e_{1}, e_{2}, r_{1}$, and $r_{2}$ for fuel rod diameter $e_{1}, e_{2}, r_{1}$, and $r_{2}$ for fuel body diameter

The errors assigned in the DATA statements should be consistent with those given in Table $2-3$.

\subsection{OUTPUT}

The results from the STRAIN code are printed out in a tabular form suitable for inclusion in test reports. The format and content of these tables is illustrated by the sample problem results given in Appendix D. STRAIN also provides punched card output containing strain and error information required as input for the DRWDIM code. 
3.6. USAGE CONSIDERATIONS

The STRAIN code is currently contained on the second file of tape 5415. The following run stream should be used to execute the code:

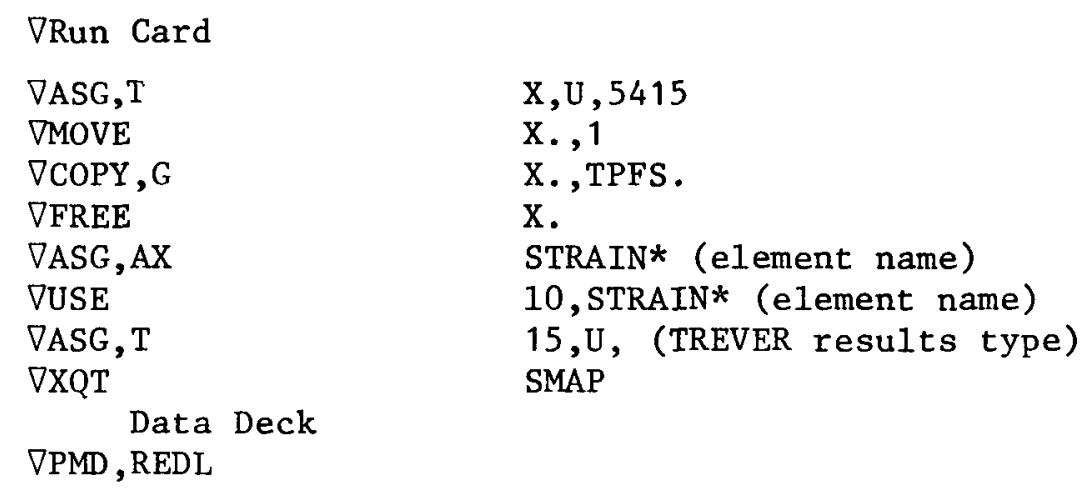

A maximum of 50 pages, a maximum time of 1 minute, and a maximum of 30 cards should be sufficient for the majority of STRAIN runs. 


\section{GAPS}

The GAPS computer code, written in August 1976, computes fuel rod fuel hole and sleeve - fuel body radial heat transfer gaps for Peach Bottom fuel test elements based on test element metrology data and compares the fuel rod - fuel hole gaps with the corresponding predicted gaps obtained from the TREVER code using the methods outlined in Ref. 1.

\subsection{CALCULATIONS}

GAPS is divided into the following four groups of calculations:

Group I: Comparison of measured and predicted fuel rod - fuel hole gaps

Computes postirradiation fuel rod - fuel hole gaps for each

fuel blend or group of fuel blends having similar

irradiation-induced strain characteristics and compares them with the corresponding predicted gaps obtained from the TREVER computer code.

Group II: Fuel rod - fuel hole gap calculations

Calculates the fuel rod - fuel hole gap for each fuel rod and for each combination of fuel rods considered by the STAT code.

Group III: Sleeve - fuel body gap calculations

Calculates sleeve - fuel body gaps based on outer sleeve diameter measurements.

Group IV: Sleeve - fuel body gap calculations

Calculates sleeve - fuel body gaps based on inner sleeve diameter measurements.

Whether or not each of these groups of calculations will be performed for a given GAPS run depends on the available metrology data and the output desired. After reading the specified options supplied in the 
input data deck, GAPS will either bypass or execute each group, all of which are entirely independent of one another. The calculations included in each of these four groups are discussed below.

4.1.1. Comparison of Measured and Predicted Fue1 Rod - Fue1 Hole Gaps (Group I)

The calculations included in this group can be divided into two subgroups. The calculations in the first subgroup are performed in order to compute fuel rod - fuel hole gaps at each core height corresponding to the center of a layer of fuel rods and to compare them with the corresponding predicted gaps. The second subgroup of calculations stratify subgroup 1 calculation results in order to compute and compare measured and predicted fuel body average and test element average fuel rod - fuel hole gaps for each fuel blend or group of fuel blends having similar irradiationinduced strain characteristics.

The calculations included in subgroup 1 are summarized in Table 4-1. As in the fuel rod strain calculations, the fuel rod data obtained from STAT must be stratified in order to obtain average fuel rod dimensional data for each fuel blend or group of fuel blends having similar irridiationinduced strain characteristics. Once again, the manner in which the fuel rods will be stratified is dictated by the way the fuel stacks were grouped for the TREVER analysis of the test element being considered and is specified via input by assigning a fuel type number to each fuel stack. For each fuel rod layer, the rods in fuel stacks which have been assigned the same fuel type number will be stratified to give average fuel rod diameter data for that fue1 type.

In order to obtain average fuel hole diameter data corresponding to the average fuel rod diameter data, the fuel hole diameters must be grouped together in the same manner as the fuel rod diameters and stratified as shown in Table 4-1. Since at the time GAPS was written, postirradiation fuel hole diameter measurements were either sparse or nonexistent for the 


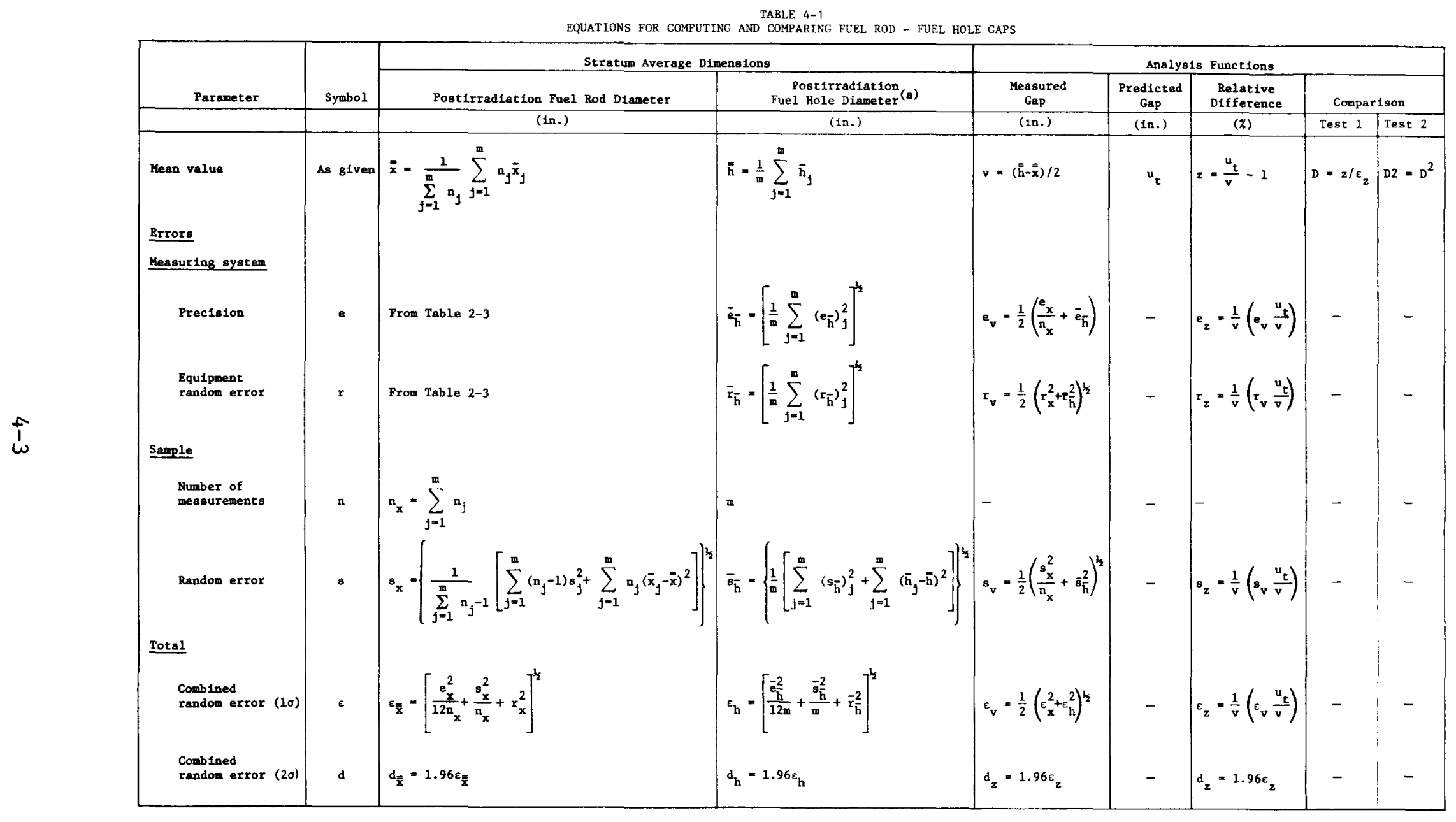

(a) Postirradiation fuel hole diameters and errors are calculated as shown in Table 4-2. 
majority of the Peach Bottom fuel test elements, it was decided to have GAPS compute postirradiation diameters and their associated errors from preirradiation and postirradiation fuel body diameter data and preirradiation fue 1 hole diameter data as shown in Table 4-2. This approach assumes that the relative shrinkage of each fuel hole and of the entire fuel body will be approximately the same at each axial location. When calculating fuel rod - fuel hole gaps at a given core height, the fuel body diameter data for the closest fuel body diameter measurement location within the same fuel body is used to compute the local postirradiation fuel hole diameter.

Since all test element metrology is performed at room temperature, the contribution of thermal strain to the predicted end-of-life gaps must be eliminated before comparing measured and predicted gaps. Therefore, instead of using the end-of-1ife gaps calculated by the TREVER code, predicted gaps which are computed from the end-of-life irradiation-induced fuel body and fuel rod strains calculated by TREVER are compared with measured strains. These are calculated using the equation

$$
\mathrm{GAP}_{2}=\mathrm{GAP}_{1}+\mathrm{d}_{\mathrm{fh}} \mathrm{U}_{\mathrm{fb}}-\mathrm{d}_{\mathrm{fr}} \mathrm{U}_{\mathrm{fr}}
$$

where $\quad \mathrm{GAP}_{1}=$ as-built preirradiation fuel rod - fuel hole gap,

$\mathrm{d}_{\mathrm{fh}}=$ preirradiation fuel hole diameter,

$\mathrm{d}_{\mathrm{fr}}=$ preirradiation fuel rod diameter,

$\mathrm{U}_{\mathrm{fb}}=$ end-of-1ife irradiation-induced fuel body strain calculated by TREVER,

$\mathrm{U}_{\mathrm{fr}}=$ end-of-life irradiation-induced fuel rod strain calculated by TREVER.

Since the 30 TREVER calculation points do not correspond to the midpoints of the fuel rod layers, GAPS interpolates the gaps obtained from TREVER in order to determine the predicted gaps for the locations at which measured gaps have been computed. As with the predicted strains, the means for determining the errors associated with the predicted gaps have yet to be developed, so these errors are assumed to be zero. 
TABLE 4-2

EQUATIONS FOR COMPUTING POSTIRRADIATION FUEL HOLE AND

INNER SLEEVE DIAMETERS AND ERRORS

\section{Key to Symbols}

$b_{1}$ Preirradiation fuel body diameter or outer sleeve diameter

$\mathrm{b}_{2}$ Postirradiation fuel body diameter or outer sleeve diameter

$h_{1}$ Preirradiation fuel hole diameter or inner sleeve diameter

$\mathrm{h}_{2}$ Postirradiation fuel hole diameter or inner sleeve diameter

Al1 other symbols, see Table 3-2.

1. Postirradiation fuel hole diameter

$$
\mathrm{h}_{2}=\mathrm{h}_{1} \frac{\mathrm{b}_{2}}{\mathrm{~b}_{1}}
$$

2. Precision (Group I on1y)

$$
e_{\bar{h}}=\frac{1}{b_{1}}\left[\frac{e_{b_{2}}}{\sqrt{n_{b_{2}}}} h_{1}+\frac{e_{h_{1}}}{\sqrt{n_{h_{1}}}} b_{2}+\frac{e_{b_{1}}}{\sqrt{n_{b_{1}}}}\left(\frac{b_{2} h_{2}}{b_{1}}\right)\right]
$$

3. Equipment Random Error (Group I only)

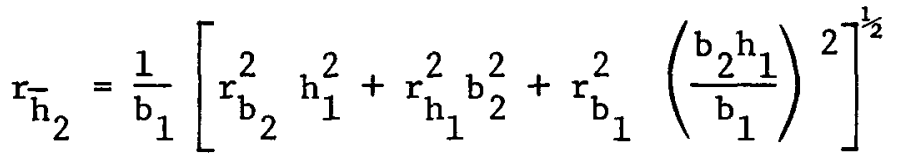

4. Sample Random Error

a. Group I (on mean)

$$
s_{h_{2}}=\frac{1}{b_{1}}\left[\frac{s_{b_{2}}^{2}}{n_{b_{2}}} h_{1}^{2}+\frac{s_{h_{1}}^{2}}{n_{h_{1}}} b_{2}^{2}+\frac{s_{b_{1}}^{2}}{n_{b_{1}}}\left(\frac{b_{2} h_{1}}{b_{1}}\right)^{2}\right]^{\frac{1}{2}}
$$




\section{TABLE 4-2 Cont.}

b. Groups II and III (on sample)

$$
s_{h_{2}}=\frac{1}{b_{1}}\left[s_{b_{2}}^{2} h_{1}^{2}+s_{h_{1}}^{2} b_{2}^{2}+s_{b_{1}}^{2}\left(\frac{b_{2} h_{1}}{b_{1}}\right)^{2}\right]^{\frac{1}{2}}
$$

5. Combined Random Error (Groups II and III)

$$
\varepsilon_{\bar{h}_{2}}=\frac{1}{b_{1}}\left[\varepsilon_{b_{2}}^{2} h_{1}^{2}+\varepsilon_{h_{1}}^{2} b_{2}^{2}+\varepsilon_{b_{1}}^{2}\left(\frac{b_{2} h_{1}}{b_{1}}\right)^{2}\right]^{\frac{1}{2}}
$$


The calculations included in subgroup 2 are identical in nature to the group 2 calculations of the STRAIN code (see Sections 3.1 and 3.1 .2 ) and are summarized in Table 3-2. The only difference is that $\mathrm{V}$ and $\mathrm{U}_{\mathrm{T}}$ are gaps instead of strains.

\subsubsection{Fuel Rod - Fuel Hole Gap Calculations (Group II)}

Fue1 rod - fuel hole gaps for individual fuel rods and average fuel rod - fuel hole gaps for single and artibrarily defined combinations of fuel holes are computed in this group. These calculations are summarized in Table 4-3. A11 fuel rod data required by these calculations are obtained from STAT code results and once again all postirradiation fuel hole diameters and errors are computed from preirradiation fuel hole diameter data and preirradiation and postirradiation fuel body diameter data using the equations given in Table 4-2. When computing the average gaps for an arbitrarily defined combination of fuel holes, additional calculations are performed to determine stratum average preirradiation fuel hole and preirradiation and postirradiation fuel body diameters and errors. The equations for these calculations are given in Table 2-2.

\subsubsection{Sleeve - Fuel Body Gap Calculations (Based on Sleeve O.D.) (Group III)}

Sleeve - fuel body gaps at each sleeve 0.D. measurement location and fuel body and fuel element average sleeve - fuel body gaps based on sleeve O.D. measurements are computed in this group. These calculations are also summarized in Table 4-3. All fuel body diameter data required by these calculations are obtained from STAT code results and all postirradiation sleeve I.D.s and errors are computed from preirradiation sleeve I.D. data and preirradiation and postirradiation sleeve 0.D. data using the equations given in Table 4.2. When calculating sleeve-fuel body gaps at a given sleeve O.D. measurement location, the code searches through the fuel body diameter data and selects the data at the nearest fuel body diameter measurement location. If the sleeve O.D. measurement location is outside 
TABLE $4-3$
EQUATIONS FOR FUEL ROD - FUEL HOLE AND SLEEVE - FUEL BODY GAP CALCULATIONS

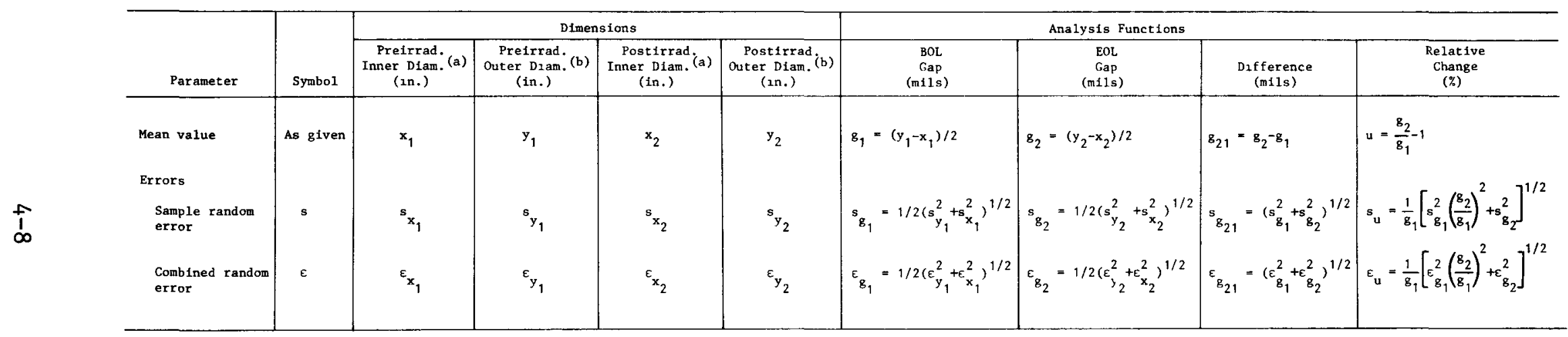

(a) Fuel rod or outer fuel body d1ameter.

(b) Fuel hole or inner sleeve diameter. For group 2 and group 3 calculations, the postirradiation fuel hole or 2 nner sleeve diameters are calculated as shown in Table 4-2. 
the active core, the corresponding preirradiation and postirradiation fuel body diameters are assumed to equal the element average preirradiation fuel body diameter.

When computing fuel body average gaps, stratification calculations (Table 2-2) are performed to determine fuel body average preirradiation inner sleeve and preirradiation and postirradiation outer sleeve diameters and errors. Element average inner and outer sleeve diameters and errors are then obtained by stratifying the fuel body average results. The sleeve 0.D. measurement locations outside of the active core are excluded from the element average gap calculations. If sleeve O.D. measurements are not available for more than one fuel body, the element average gap calculations wil1 not be performed.

\subsubsection{Sleeve - Fuel Body Gap Calculations (Based on Sleeve I.D.) (Group IV)}

The calculations included in this group compute sleeve - fuel body gaps at each sleeve I.D. measurement location and fuel body and fuel element average sleeve - fuel body gaps based on sleeve I.D. measurements. These calculations are identical to the group 3 calculations with the exception that sleeve I.D. information is obtained directly from STAT code results rather than being calculated from the sleeve strain as determined from preirradiation and postirradiation sleeve outer diameter measurements.

\subsection{STRUCTURE}

GAPS consists of a main program, called MAIN, and a series of short subroutines, each of which performs a specific calculation or group of calculations. The main program is responsible for reading the input data, performing or calling subroutines to perform calculations, and printing the results. The subroutines and their functions are listed below. 
Subroutine

AERF

AMEAN

CALC

CALC'1

CALC2

CONVT

CONVT1

RMS

STRAT
Function

Solves the equation $\varepsilon_{\overline{\bar{x}}}=\left[\frac{e^{\frac{2}{\bar{x}}}}{12}+s_{\overline{\bar{x}}}+r^{2}\right]^{1 / 2}$

Solves the equation $\overline{\bar{x}}=\frac{1}{M} \sum_{j=1}^{m} \bar{x}_{j}$

Computes the "analysis functions" of Table 4-3 and the associated errors.

Computes the "analysis functions" of Table 4-1 and the associated errors.

Computes stratum average grand means and errors using Eqs. 1, 2a, and 4 of Table 2-2.

Solves Eqs. 1, $4 \mathrm{~b}$ and 5 of Table 4-2. Computes postirradiation fuel hole and inner sleeve diameters and errors for use in group II, III, and IV calculations.

Solves equations $1,2,3$, and $4 a$ of Table 4-2. Computes postirradiation fuel hole diameters and errors for use in group 1 calculations.

Computes RMS as defined in Table 3-2. Computes all $\overline{\mathrm{E}}_{\bar{a}}$ as defined in Table $3-2$.

\subsection{PROGRAM LIMITS}

The dimensions of the arrays used in GAPS are specified by parameters which are defined in MAIN, CALC, and CALC1. These parameters and their currently assigned values are listed below. 
Parameter

NB

$\mathrm{NH}$

NR

NS

NSS

NL or

NBS

NFT
Description

Maximum number of fuel bodies

Maximum number of fuel holes per fuel body

Maximum number of fuel rods per fue 1 stack

Maximum number of strata which can be specified in group 2

Maximum number of fuel stacks in one of the strata specified in group 2

Maximum number of axial measurement locations per fuel body

Maximum number of fuel blends
Value

\section{6}

8

14

24

24

25

10

As long as the values of these parameters are at least as large as those specified for the corresponding parameters in the STAT code, no difficulties concerning array size should be encountered. The GAPS code currently requires approximately $25 \mathrm{~K}$ words of memory.

\subsection{INPUT}

The following input is required by the GAPS code:

1. A card deck formulated as specified by the input instructions given in Appendix $\mathrm{E}$.

2. A TREVER results tape containing predicted strains (unit 15).

3. A STAT results tape or catalogued file containing fuel rod data (unit 10).

Items 2 and 3 are the same as items 2 and 3 required as input to the STRAIN code. The precision and equipment random errors associated with Peach Bottom fuel test element metrology are assigned internally via DATA statements in MAIN and in CALC2. These errors are identified below. 
Subroutine

CALC1

CALC 1

CALC1

CALC1

CALC1

MAIN

MAIN

MAIN

MAIN
Variable Name in Code

$E(1)$ and $R(1)$

$E(2)$ and $R(2)$

$E(3)$ and $R(3)$

$E(4)$ and $R(4)$

$E(5)$ and $R(5)$

$\mathrm{EX} 2$ and $\mathrm{RX} 2$

$\mathrm{EH} 1$ and RH1

EB1 and RB1

EB2 and RB2
Description

(Notations from Table 2-3)

$e_{1}$ and $r_{1}$ for fuel body

O.D.

$e_{2}$ and $r_{2}$ for $f u e 1$ body

O.D.

$e_{1}$ and $r_{1}$ for $f u e l$ hole

diameter

$e_{1}$ and $r_{1}$ for sleeve I.D.

or O.D.

$e_{2}$ and $r_{2}$ for sleeve I.D.

or O.D.

$e_{2}$ and $r_{2}$ for fuel rod

diameter

$e_{1}$ and $r_{1}$ for fuel hole

diameter

$e_{1}$ and $r_{1}$ for fuel body O.D.

$e_{2}$ and $r_{2}$ for fuel body $0 . \mathrm{D}$.

The errors assigned via these DATA statements should be consistent with those given in Table 2-3. 
4.5 OUTPUT

The results from the GAPS code are printed out in tabular form suitable for inclusion in test reports. The format and content of these tables are illustrated by the sample problem results given in Appendix F. GAPS also provides punched card output containing gap and error information required as input for the DRWDIM code.

\subsection{USAGE CONSIDERATIONS}

The GAPS code is current1y contained on the third file of tape 5415. The following run stream should be used to execute the code:

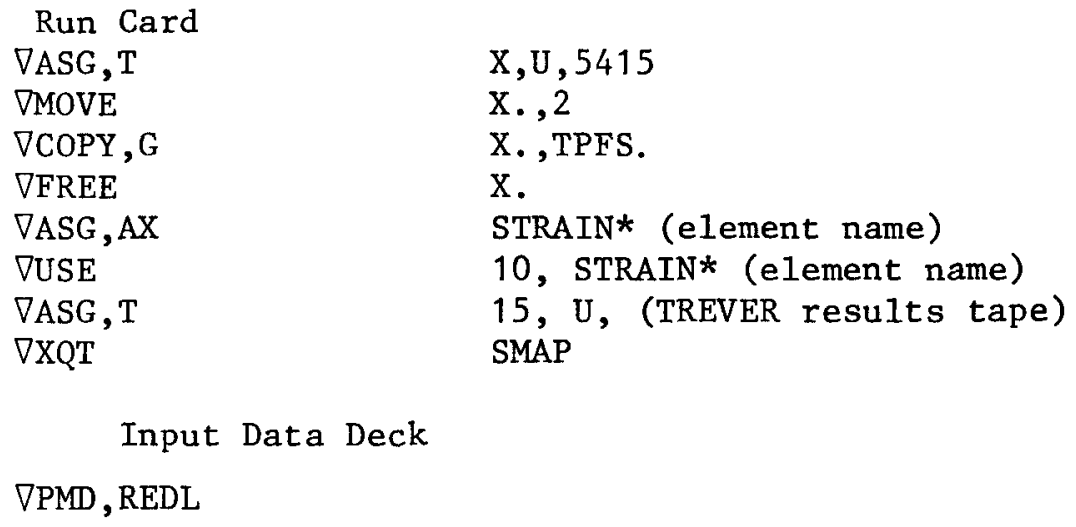

A minimum of 100 pages, a maximum time of 2 minutes, and a maximum of 200 cards should be sufficient for the majority of GAPS runs. 


\section{DRWDIM}

DRWDIM is a short plotting program which utilizes the CSD*PLOT package to prepare graphs which compare measured test element strains and gaps with the corresponding TREVER design code predictions. The measured strains and gaps, along with their $2 \sigma$ errors, are read into the program from cards which have been punched by the STAT, STRAIN, and GAPS codes. Predicted end-of-life strains are read from the TREVER results tape and then used to calculate end-of-life sleeve - fuel body and fuel rod - fuel hole gaps as follows:

Sleeve - fuel body gap

$$
\operatorname{Gap}_{2}=\left[\operatorname{Gap}_{1}-\left(\mathrm{r}_{\mathrm{fb}}\right)_{1} \frac{\mathrm{U}_{\mathrm{fb}}}{100}+\left(\mathrm{r}_{\mathrm{s}}\right)_{1} \frac{\mathrm{U}_{\mathrm{sI}}}{100}\right] \times 1000
$$

Fuel rod - fuel hole gap

$$
\mathrm{Gap}_{2}=\left[\mathrm{Gap}_{1}-\left(\mathrm{r}_{\mathrm{fr}}\right)_{1} \frac{\mathrm{U}_{\mathrm{fr}}}{100}+\left(\mathrm{r}_{\mathrm{fh}}\right)_{1} \frac{\mathrm{U}_{\mathrm{fb}}}{100}\right] \times 1000
$$

where

$$
\begin{aligned}
& \operatorname{Gap}_{2}=\text { postirradiation gap in mils, } \\
& \operatorname{Gap}_{1}=\text { preirradiation gap in inches, } \\
& \left(\mathrm{r}_{\mathrm{fb}}\right)_{1}=\text { nominal preirradiation fuel body radius in inches, } \\
& \left(\mathrm{r}_{\mathrm{s}}\right)_{1}=\text { nominal preirradiation inner sleeve radius in inches, } \\
& \left(\mathrm{r}_{\mathrm{fr}}\right)_{1}=\text { nominal preirradiation fuel rod radius in inches, } \\
& \left(\mathrm{r}_{\mathrm{fh}}\right)_{1}=\text { nominal preirradiation fuel hole radius in inches, }
\end{aligned}
$$




$$
\begin{array}{ll}
\mathrm{U}_{\mathrm{fb}} & =\text { end-of-life fuel body irradiation strain in } \% \\
\mathrm{U}_{\mathrm{Sl}} & =\text { end-of-life sleeve irradiation strain in } \% \\
\mathrm{U}_{\mathrm{fr}} & =\text { end-of-life fuel rod irradiation strain in } \%
\end{array}
$$

DRWDIM will plot a11 or any combination of the following sets of data depending on the instructions provided in the input data deck:

1. Measured and predicted sleeve - fuel body gaps.

2. Measured and predicted fuel rod - fuel body gaps.

3. Measured and predicted sleeve strains.

4. Measured and predicted fuel body strains.

5. Measured and predicted fuel rod strains.

When plotting fuel rod - fuel hole gaps or fuel rod strains, DRWDIM will produce one plot for each fuel blend or group of fuel blends having similar irradiation-induced strain characteristics (see Sections 3.1 and 4.1).

The following run stream is required to execute the program:

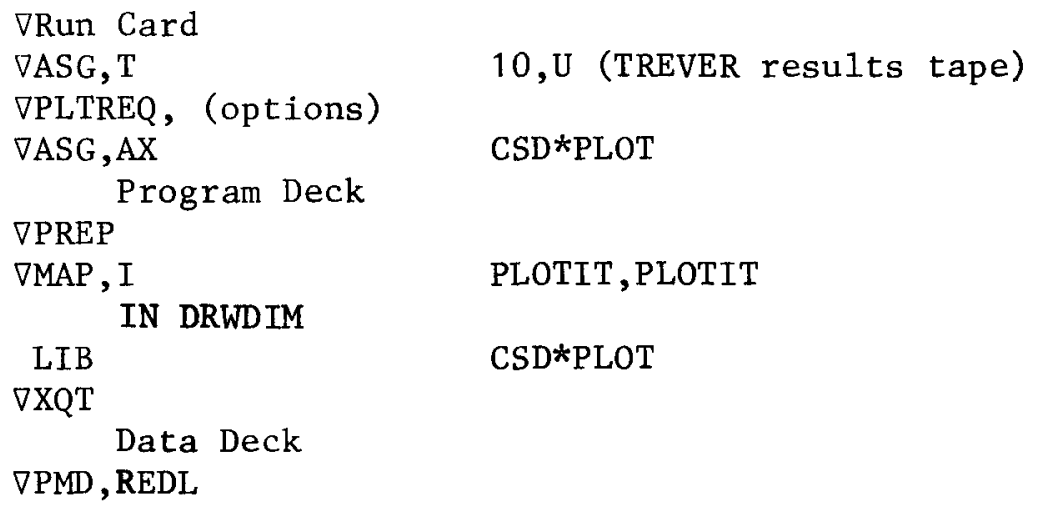

The input instructions for this program are given in Appendix $G$ and a sample run has been included as Appendix $\mathrm{H}$.

$$
5-2
$$




\section{REFERENCES}

1. Wallroth, C. F., J. F. Holzgraf, and D. D. Jensen, "PostIrradiation Examination and Evaluation of Peach Bottom Fuel Test Element FTE-6," Section 4.1, General Atomic Report GA-A-13943, to be published.

2. Saurwein, J. J., "Peach Bottom Test Element Thermal Analysis," General Atomic unpublished data, Apri1 19, 1976.

3. Korts, R. F., "Program STAT," General Atomic unpublished data, May 27, 1976.

4. Holzgraf, J. F., and M. Miller, "Preirradiation Measurements of Sleeve Sections from Peach Bottom Historical Specimens," General Atomic unpublished data, May 19, 1976.

5. Vrouwes, J., "Diameter of Phase 2 Test Element Fuel Rods - Comparison Between Micrometer and Air Gauge Measurements Implying Possible Decrease in Heat Transfer Characteristics," Genera1 Atomic unpublished data, July 22, 1971.

6. Dixon, W. J. and F. J. Massey, Jr., Introduction to Statistical Analysis, McGraw-Hil1 Book Company, 1969. 
APPENDIX A

STAT INPUT INSTRUCTIONS 


\begin{tabular}{|c|c|c|c|c|c|c|c|c|}
\hline Column & I-6 & $7-\sqrt[12]{2}$ & $13-18$ & $19-24$ & $25-30$ & $31-36$ & $37-42$ & \\
\hline Format & 16 & 16 & 16 & I6 & I6 & I6 & 16 & \\
\hline Name & $\operatorname{IOPT}(1)$ & IOPT (2) & IOPT (3) & IOPT (4) & IOPT (5) & IOPT $(6)$ & JOPT & $=$ \\
\hline 1 & $\begin{array}{l}\text { 1- Process } \\
\text { element } \\
\text { length and } \\
\text { fuel body } \\
\text { weight data } \\
0-\text { Do not } \\
\text { precees } \\
\text { these data }\end{array}$ & $\begin{array}{l}\text { 1- Process } \\
\text { fuel rod } \\
\text { diameter and } \\
\text { length data } \\
0-\text { Do not } \\
\text { process these } \\
\text { data }\end{array}$ & $\begin{array}{l}\text { 1- Process } \\
\text { fuel body } \\
\text { diameter and } \\
\text { length data } \\
0-\text { Do not } \\
\text { process these } \\
\text { data }\end{array}$ & $\begin{array}{l}\text { 1- Process } \\
\text { fuel hole } \\
\text { diameter data } \\
0-D o \text { not } \\
\text { process these } \\
\text { data }\end{array}$ & $\begin{array}{l}\text { 1- Process } \\
\text { inner and } \\
\text { outer sleeve } \\
\text { dlameter } \\
\text { data } \\
\text { O- Do not } \\
\text { process these } \\
\text { data }\end{array}$ & $\begin{array}{l}\text { 1- Process } \\
\text { fue1 stack } \\
\text { and fuel hole } \\
\text { plenum length } \\
\text { data } \\
\text { O- Do not pro- } \\
\text { cess these } \\
\text { data }\end{array}$ & $\begin{array}{l}1 \text { - Add } 0.003 \text { in. } \\
\text { to all pre- } \\
\text { 1rradlation } \\
\text { fuel rod } \\
\text { uremeants } \\
0-\text { Do not add } \\
0.003 \mathrm{La} \text {. }\end{array}$ & \\
\hline
\end{tabular}

\begin{tabular}{|l|}
\hline Comments \\
This card is part of the \\
initial date deck but \\
1s not 1ncluded In the \\
catalogued f1le. It \\
must be included with \\
all STAT runs. See \\
Section 2.6. \\
\end{tabular}

\begin{tabular}{|l|c|}
\hline Columan & $1-\mathrm{BO}$ \\
\hline Pormat & CARD \\
\hline Name & \\
\hline & \\
\hline & $\begin{array}{c}\text { Comment cards giving general information concerning the } \\
\text { test element being analyzed }\end{array}$ \\
\hline
\end{tabular}
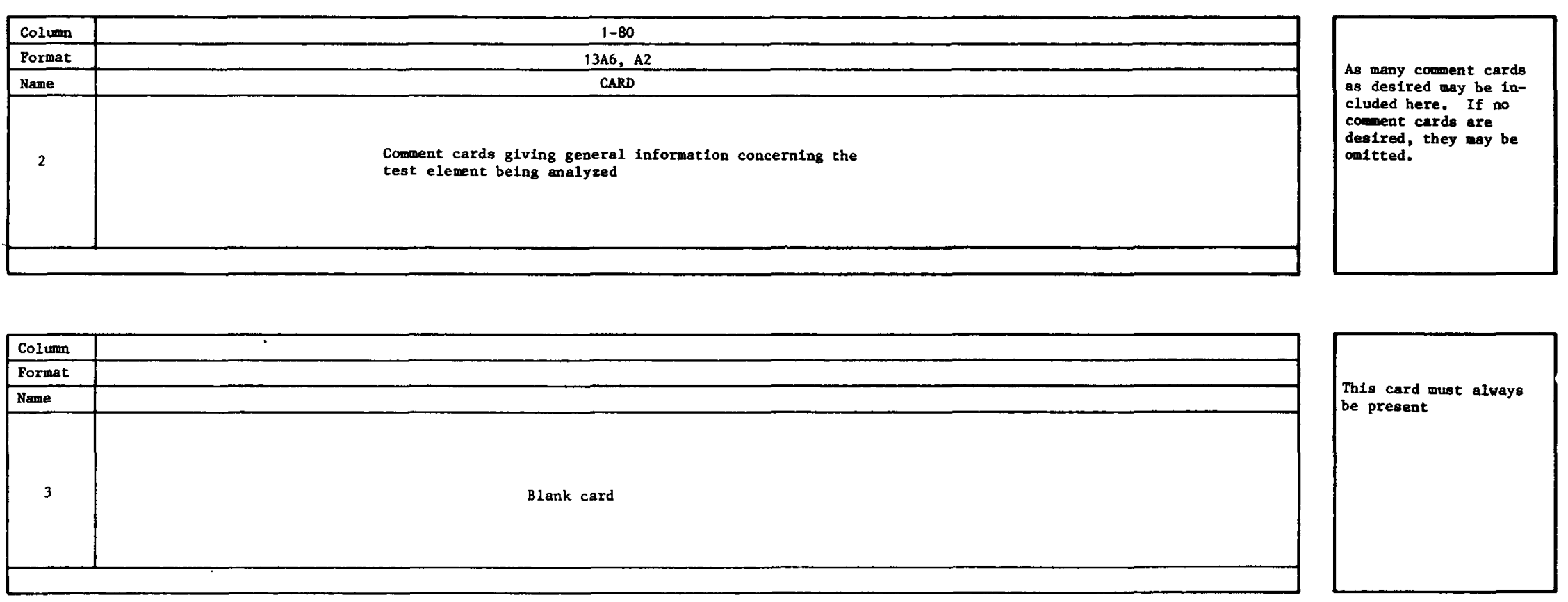


\begin{tabular}{|c|l|l|l|l|}
\hline Cotumn & \multicolumn{1}{|c|}{$1-12$} & $13-24$ & $25-36$ & \\
\hline Format & 2A6 & F12.0 & F12.0 & \\
\hline Name & ID(1)\& ID(2) & EBL & EAL & \\
\hline 4 & $\begin{array}{l}\text { Test element } \\
\text { name (left } \\
\text { justified) }\end{array}$ & $\begin{array}{l}\text { Preirradia- } \\
\text { tion fue1 } \\
\text { element } \\
\text { length } \\
\text { (inches) }\end{array}$ & $\begin{array}{l}\text { Postirradia- } \\
\text { tion element } \\
\text { length } \\
\text { (inches) }\end{array}$ & \\
\hline
\end{tabular}
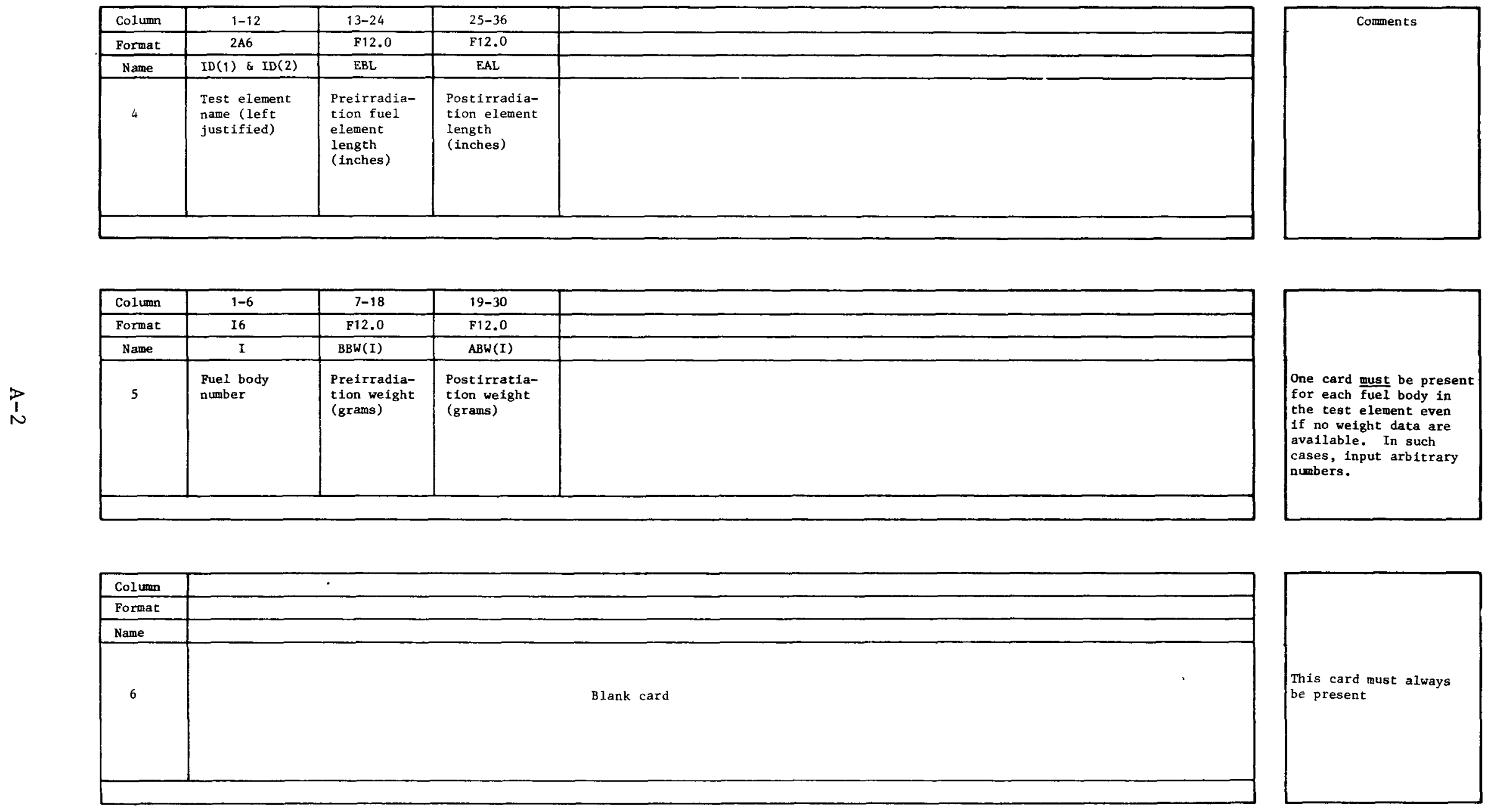

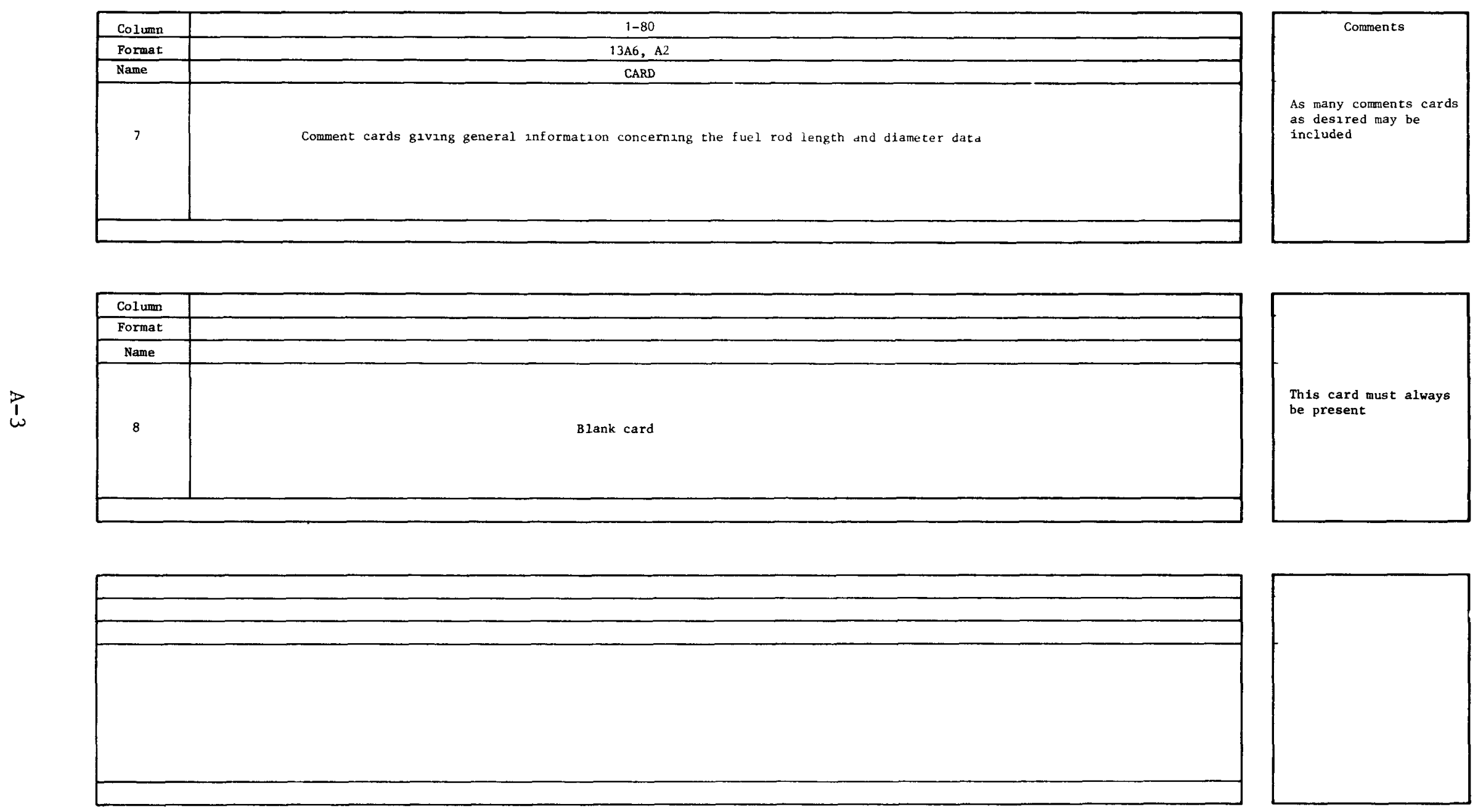


\begin{tabular}{|c|c|c|c|c|c|c|c|c|}
\hline Column & $1-6$ & $7-12$ & $13-18$ & $19-30$ & $31-36$ & $37-42$ & $43-48$ & $49-54$ \\
\hline Format & I6 & I6 & I6 & $\mathrm{F} 12.0$ & I6 & I6 & I6 & I6 \\
\hline Name & IB & IH & IR & $\mathrm{CHR}(\mathrm{IB}, \mathrm{IH}, \mathrm{IR})$ & $\mathrm{NP}(1)$ & $\mathrm{NP}(2)$ & NP(3) & $\mathrm{NP}(4)$ \\
\hline 9 & $\begin{array}{l}\text { Fue1 } \\
\text { body } \\
\text { number }\end{array}$ & $\begin{array}{l}\text { Fuel } \\
\text { hole } \\
\text { number }\end{array}$ & $\begin{array}{l}\text { Fuel } \\
\text { rod } \\
\text { number }\end{array}$ & $\begin{array}{l}\text { Total core } \\
\text { height of } \\
\text { fuel rod center } \\
\text { (1nches) }\end{array}$ & $\begin{array}{l}\text { Number of preirra- } \\
\text { diation length } \\
\text { measurements for } \\
\text { this fuel rod }\end{array}$ & $\begin{array}{l}\text { Number of postirra- } \\
\text { diation length } \\
\text { measurements for } \\
\text { this fuel rod }\end{array}$ & $\begin{array}{l}\text { Number of preirra- } \\
\text { dratzon diameter } \\
\text { measurements for } \\
\text { this fuel rod }\end{array}$ & $\begin{array}{l}\text { Number of postirra- } \\
\text { dration diameter } \\
\text { measurements for } \\
\text { this fuel rod }\end{array}$ \\
\hline
\end{tabular}
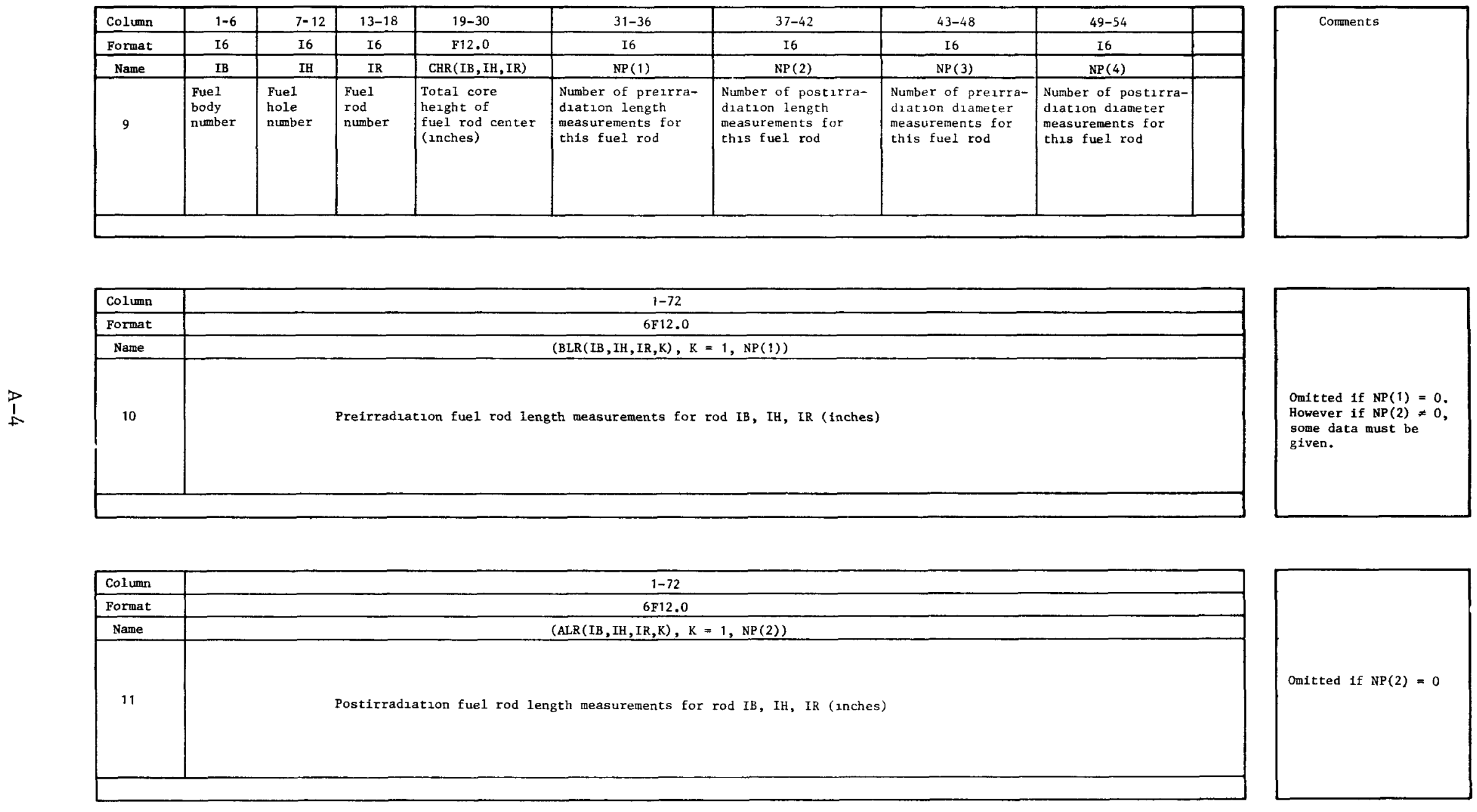

\begin{tabular}{|c|c|}
\hline Column & $1-72$ \\
\hline Format & $6 \mathrm{~F} 12,0$ \\
\hline Name & (ALR(IB,IH,IR, K), K=1, NP(2)) \\
\hline & \\
& Postirradiation fuel rod length measurements for rod IB, IH, IR (Inches) \\
& \\
\hline
\end{tabular}

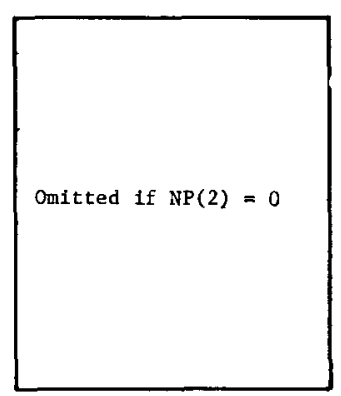




\begin{tabular}{|c|c|}
\hline Column & $1-72$ \\
\hline Format & (BDR (IB, IH, IR, K), K $=1, \mathrm{NP}(3))$ \\
\hline Name & $\begin{array}{c}\text { Preirradiation fuel rod diameter measurements for rod IB, IH, IR } \\
\text { (1nches) }\end{array}$ \\
\hline 12 & \\
\hline
\end{tabular}
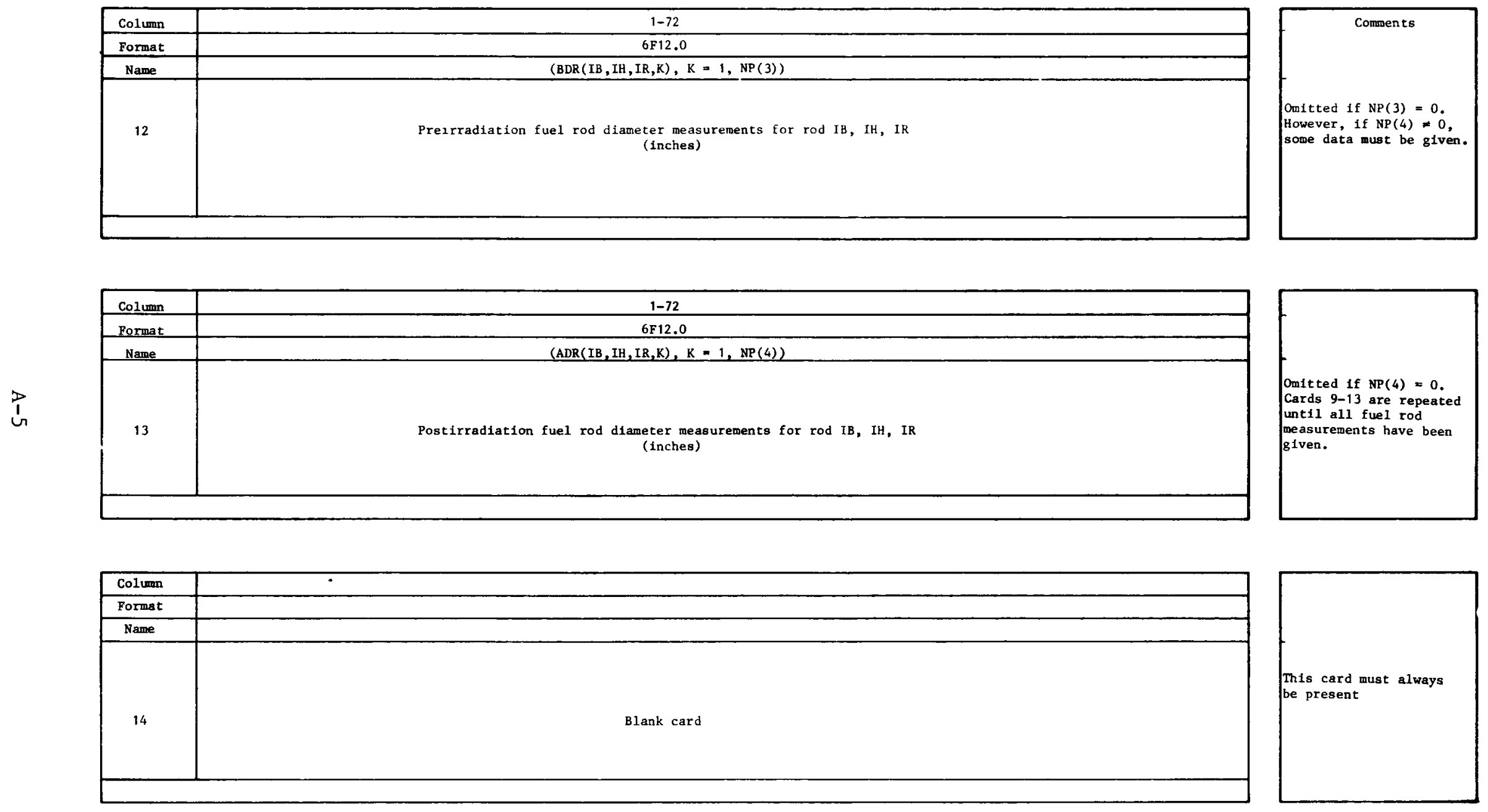


\begin{tabular}{|c|c|c|c|c|}
\hline Col umn & $1-6$ & $7-9$ & $10-12$ & $13-78$ \\
\hline Format & I6 & I3 & $\mathrm{I}-3$ & 2213 \\
\hline Name & ISN & $\operatorname{NRSD}(\operatorname{ISN}, 1,1)$ & $\operatorname{NRSD}($ ISN $, 1,2)$ & $\operatorname{NRSD}(\operatorname{ISN}, \mathrm{J}, 1), \operatorname{NRSD}(\operatorname{ISN}, \mathrm{J}, 2)$ \\
\hline 15 & $\begin{array}{l}\text { Stratum 1dent1- } \\
\text { fication. } \\
\text { number }\end{array}$ & $\begin{array}{l}\text { Fuel body in } \\
\text { which first fuel } \\
\text { stack in straturn } \\
\text { is located }\end{array}$ & $\begin{array}{l}\text { Fuel hole in } \\
\text { which first fuel } \\
\text { stack in stratum } \\
\text { is located }\end{array}$ & $\begin{array}{l}\text { Identification of fuel bodies and fuel hules for all fuel } \\
\text { stacks ancluded in the stratum. NRSD (ISA, J, 1) and } \\
\text { NRSD(ISN,J,2) will alternate and be given in I3 format. }\end{array}$ \\
\hline
\end{tabular}
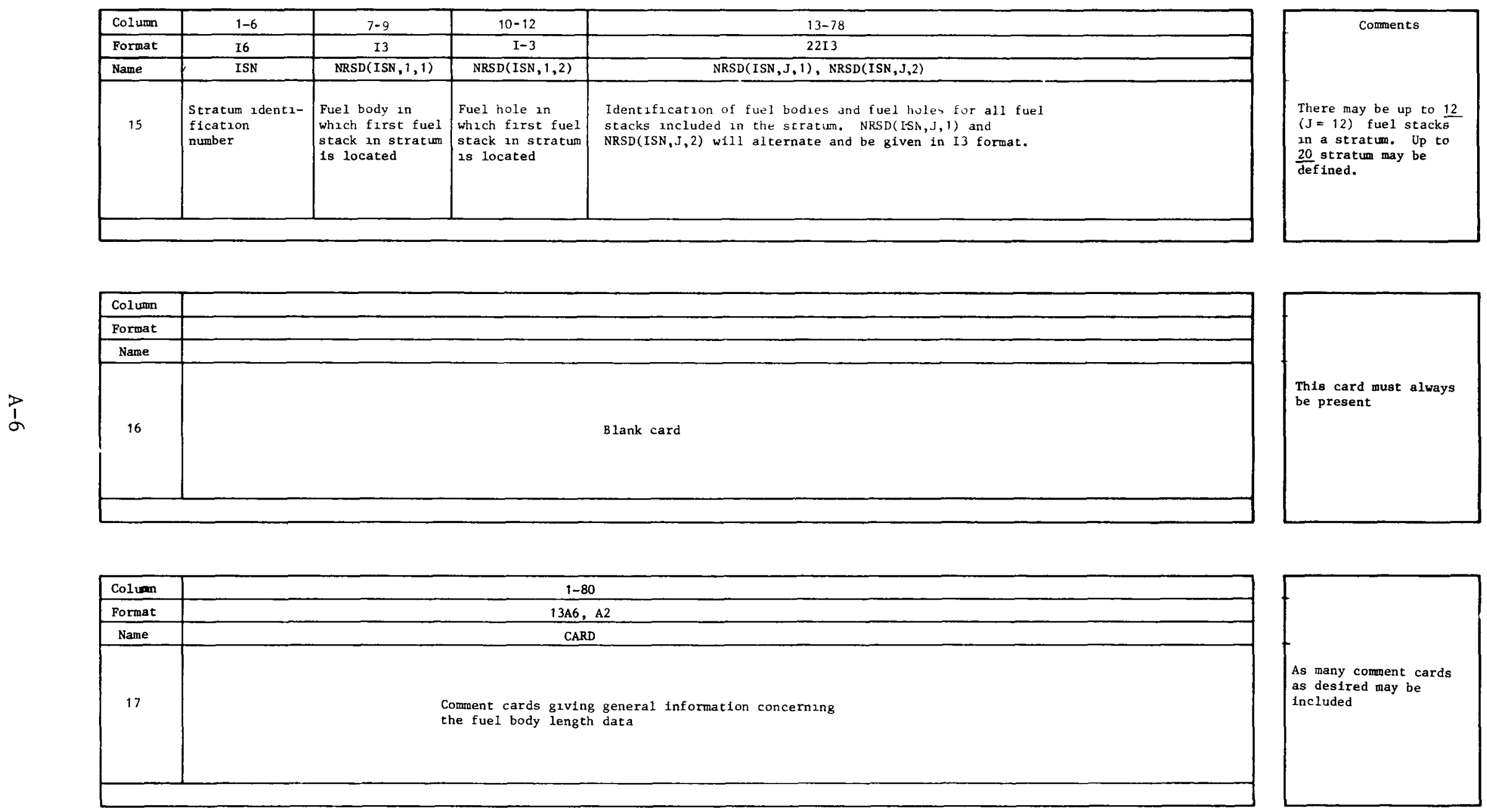

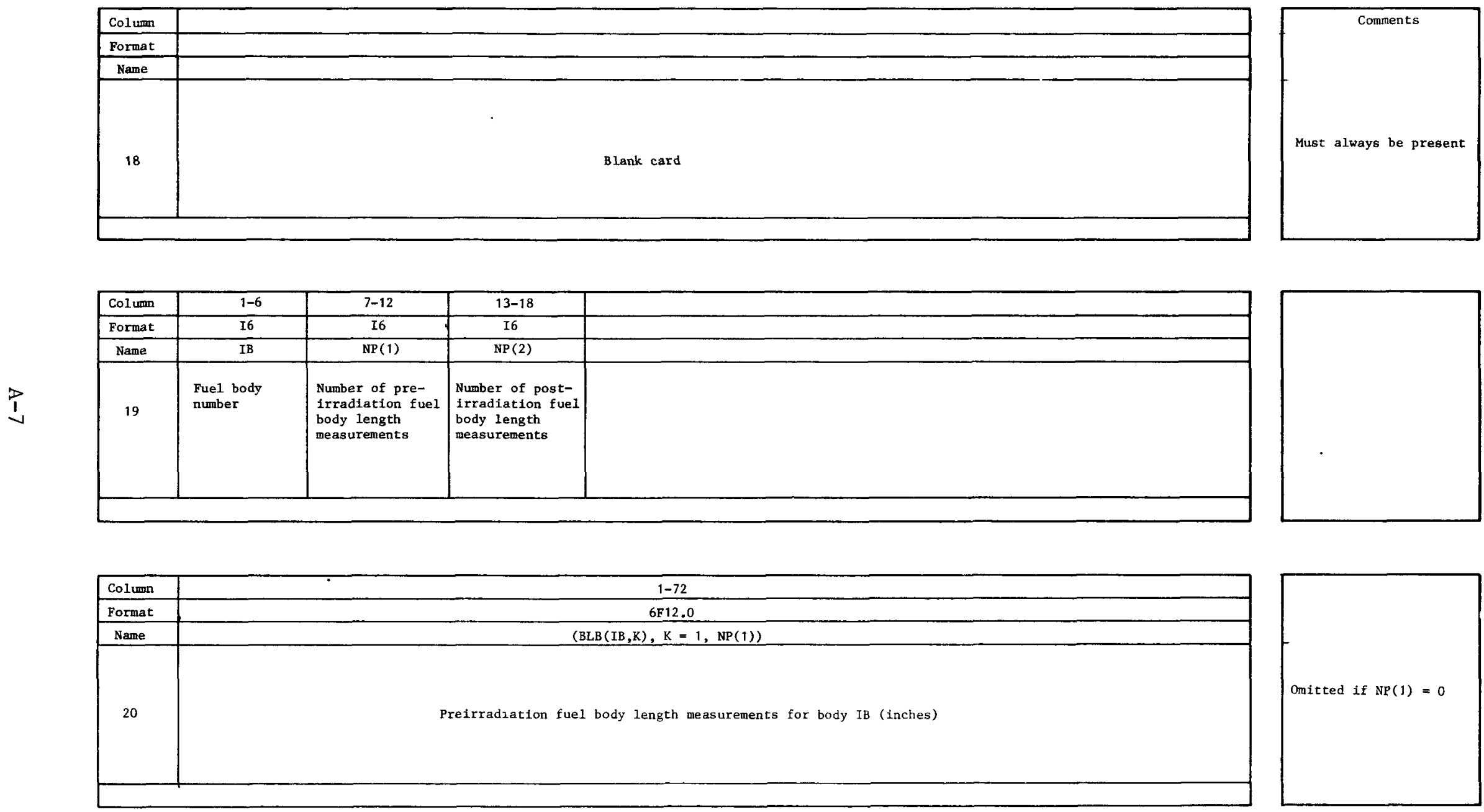


\begin{tabular}{|l|c|}
\hline Column & $1-72$ \\
\hline Format & BLB(IB, K), $\mathrm{K}=1, \mathrm{NP}(2))$ \\
\hline Name & \\
\hline & \\
\hline & Postirradation fuel body $\begin{array}{l}\text { length measurements for body } 1 \mathrm{~B} \\
\text { (1nches) }\end{array}$ \\
\hline
\end{tabular}
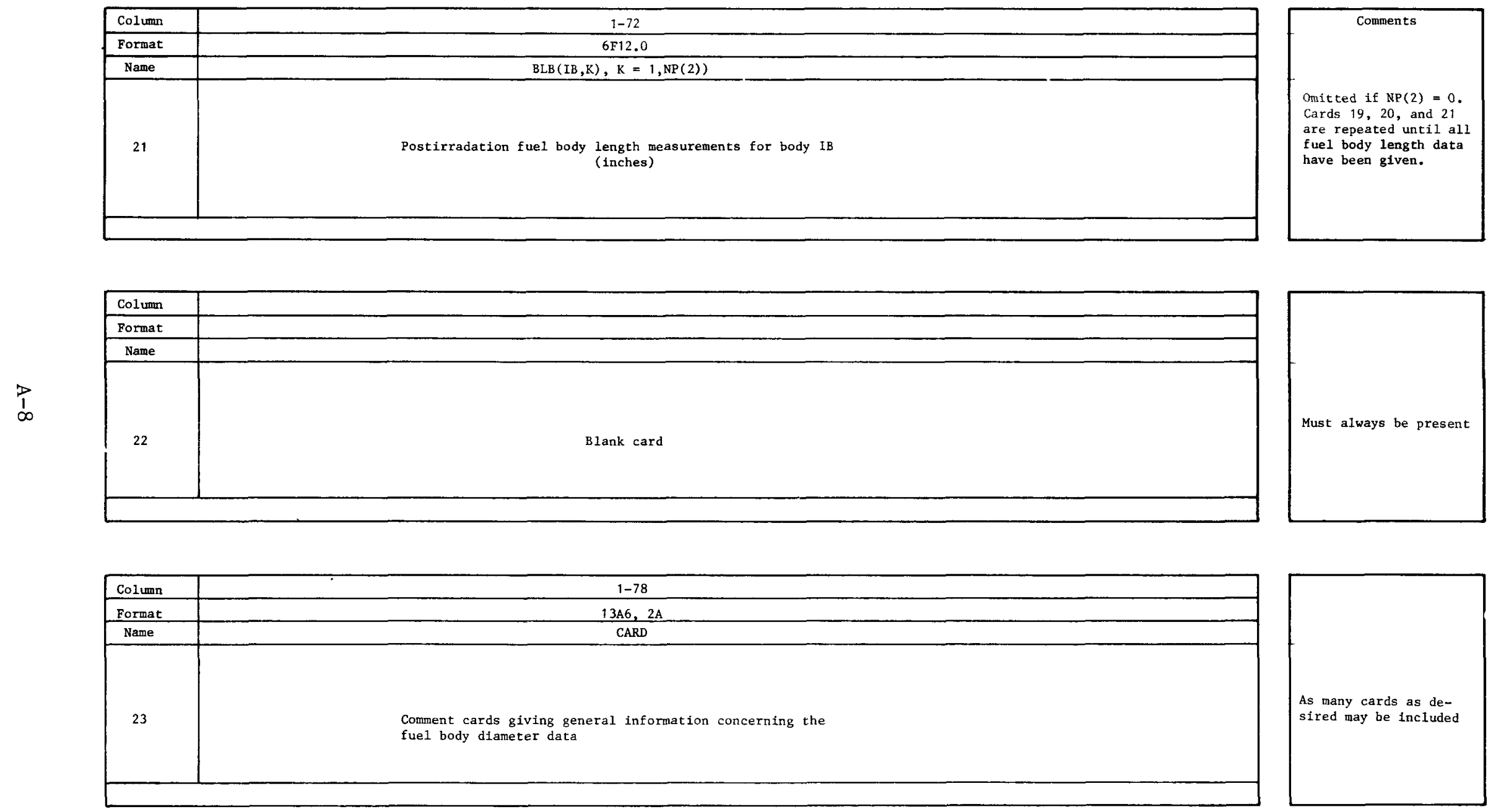

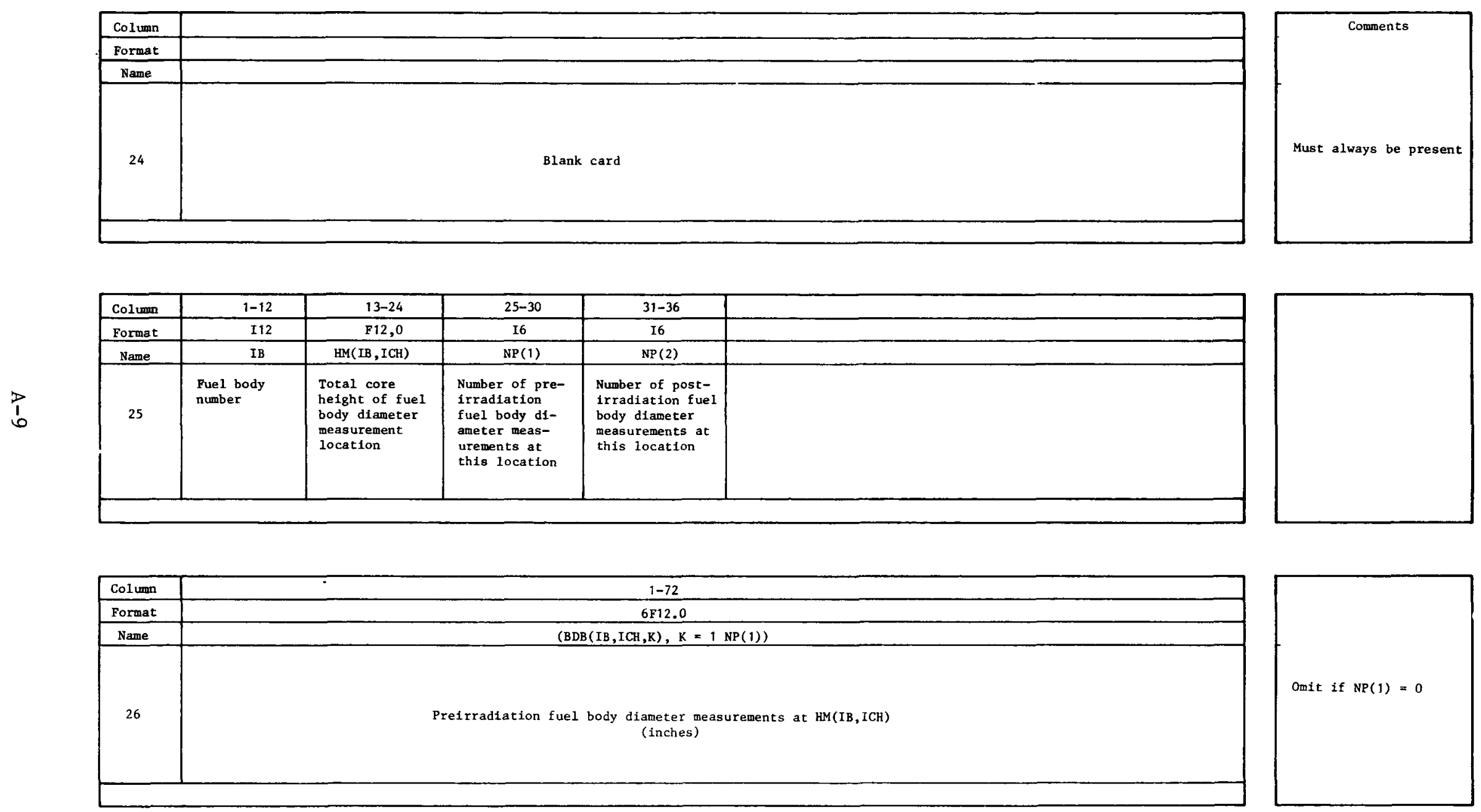

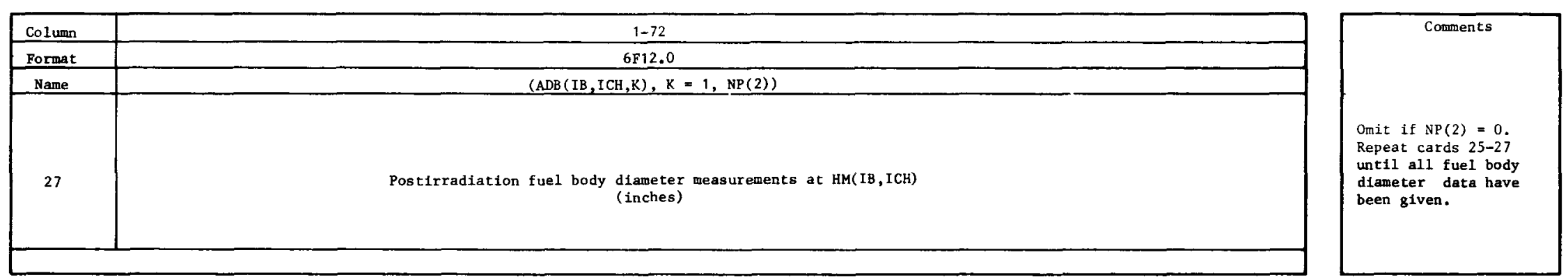

$\frac{1}{0}$
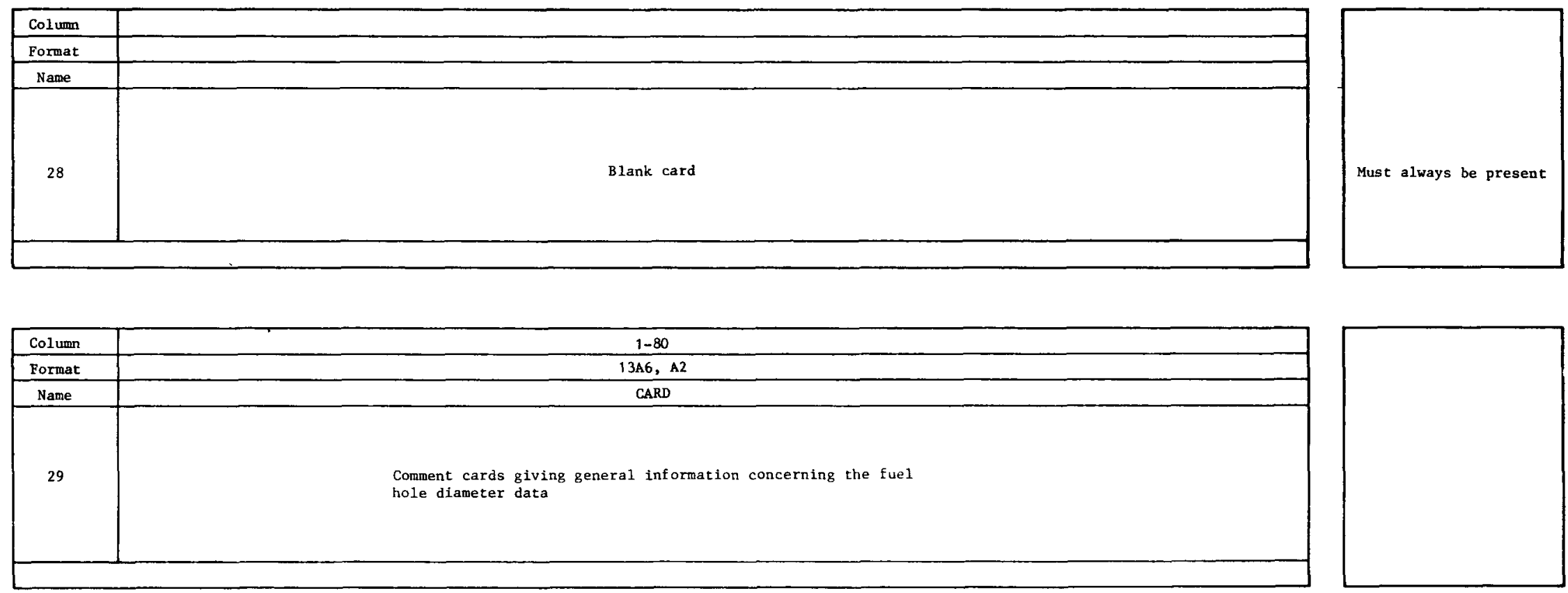

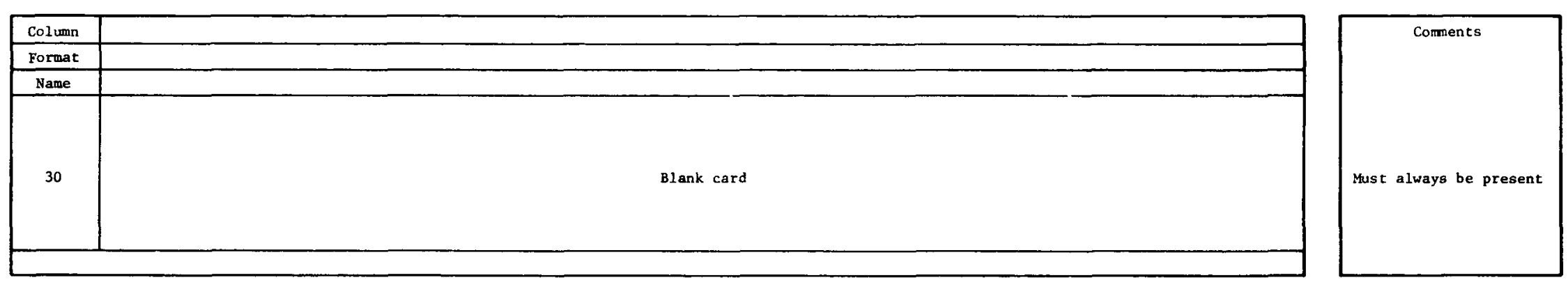

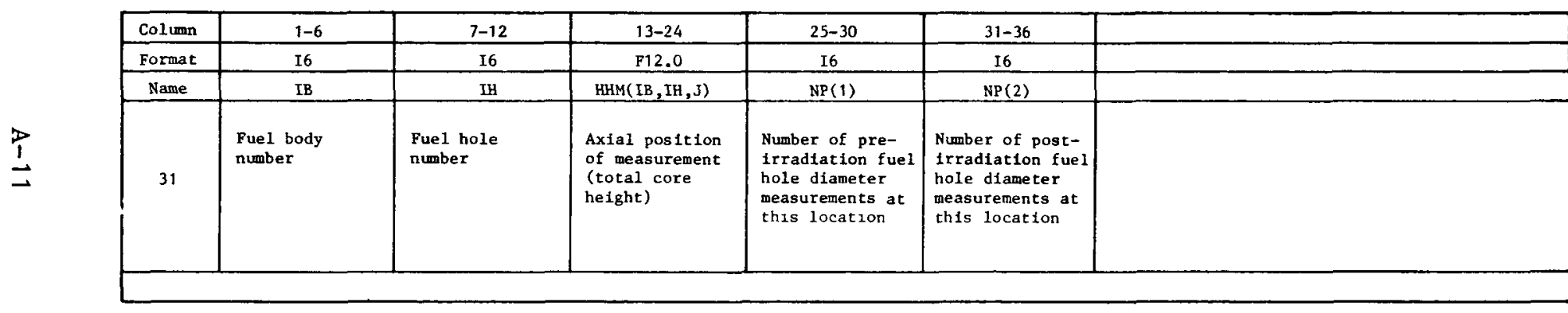
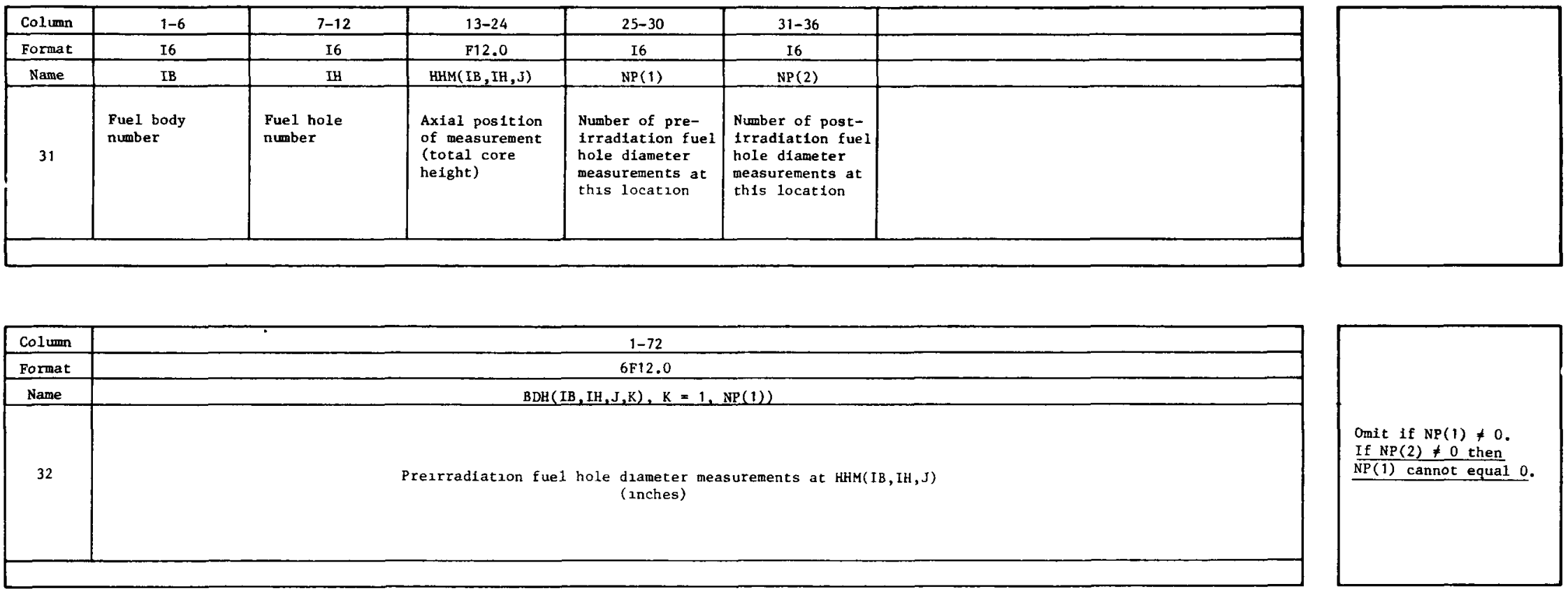


\begin{tabular}{|c|c|}
\hline Column & $1-72$ \\
\hline Format & $6 F 12.0$ \\
\hline Name & $(\mathrm{ADH}(\mathrm{IB}, \mathrm{IH}, \mathrm{J}, \mathrm{K}), \mathrm{K}=1 \mathrm{NP}(2))$ \\
\hline 33 & $\begin{array}{l}\text { Postirradiation fuel hole diameter measurements at } \mathrm{HHM}(\mathrm{IB}, \mathrm{IH}, \mathrm{J}) \\
\text { (inches) }\end{array}$ \\
\hline
\end{tabular}

\begin{tabular}{|l|}
\hline \multicolumn{1}{|c|}{ Comments } \\
Omit if NP(2) $=0$. \\
Repeat cards $31-33$ \\
until all fuel hole \\
diameter data have \\
been given.
\end{tabular}
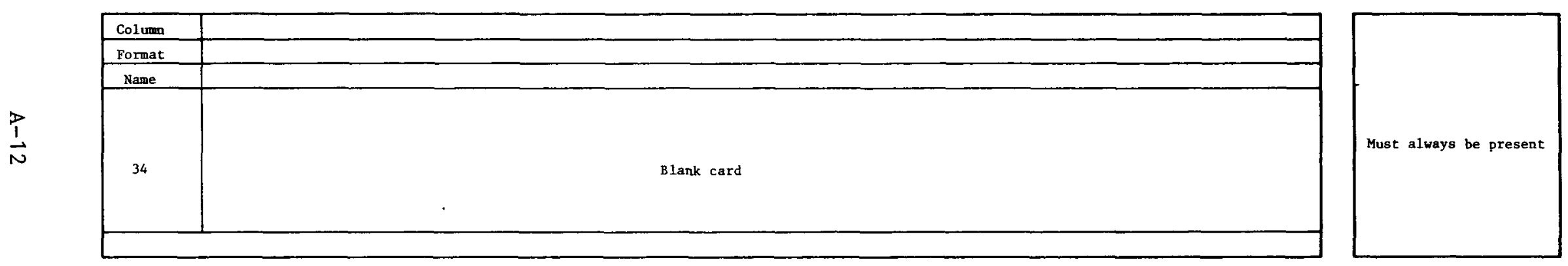

\begin{tabular}{|c|c|}
\hline Column & $1-80$ \\
\hline Format & $13 \mathrm{~A} 6, \mathrm{~A} 2$ \\
\hline Name & CARD \\
\hline 35 & $\begin{array}{l}\text { Conment cards giving general information concerning } \\
\text { the outer sleeve diameter data }\end{array}$ \\
\hline
\end{tabular}

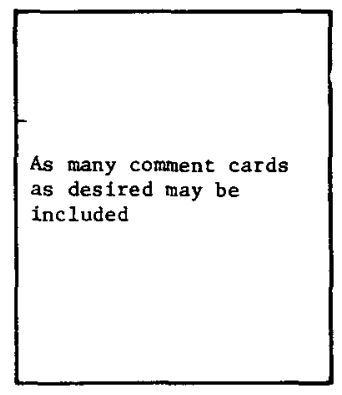



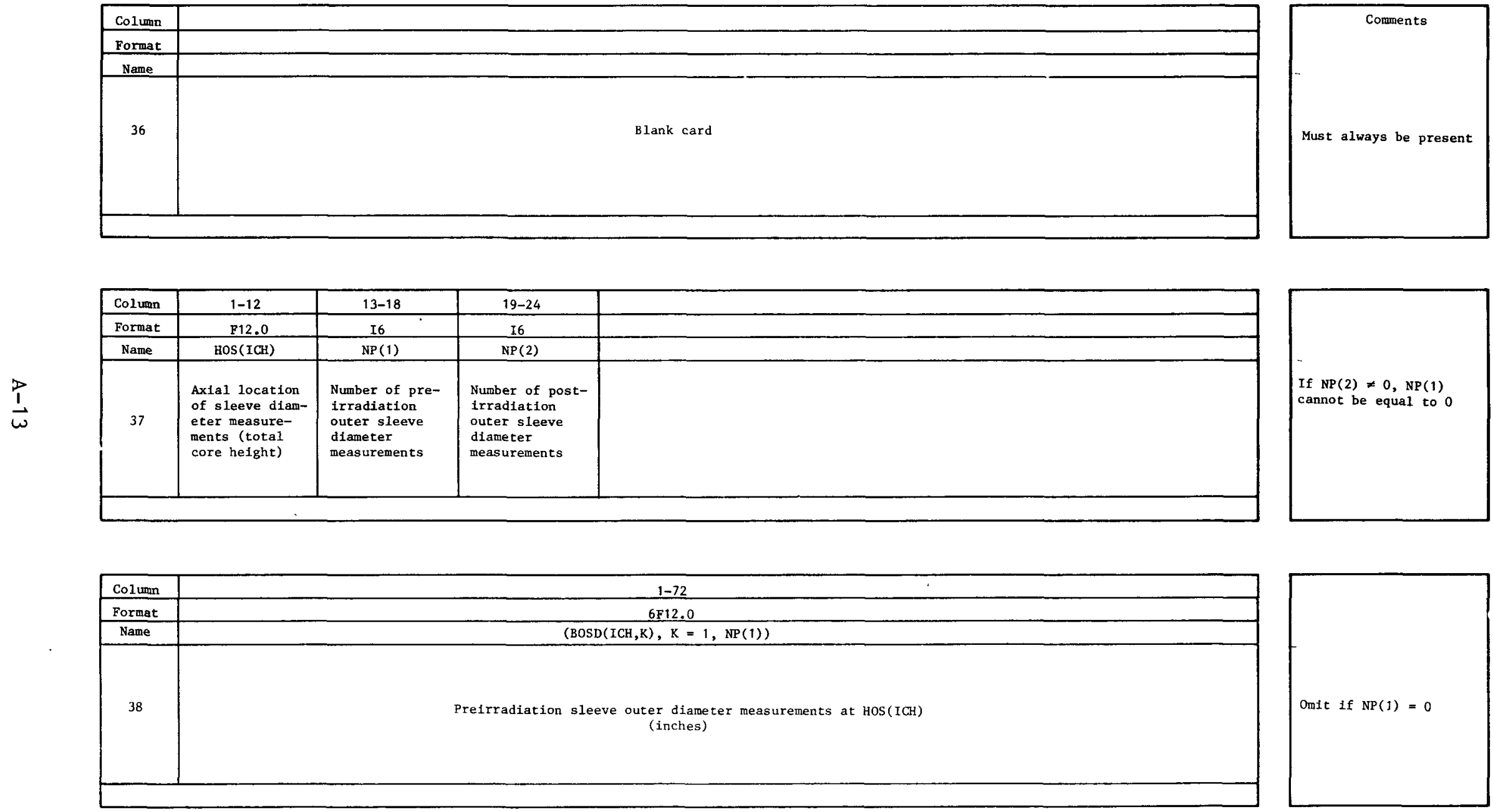


\begin{tabular}{|l|c|}
\hline Columm & $1-72$ \\
\hline Pormat & $6 \mathrm{~F} 12.0$ \\
\hline Name & (AOSD(ICH, K), $\mathrm{K}=1 \mathrm{NP}(2))$ \\
\hline & \\
39 & Postirradiation sleeve outer diameter measurements at HOS (ICH) \\
& \\
\hline
\end{tabular}
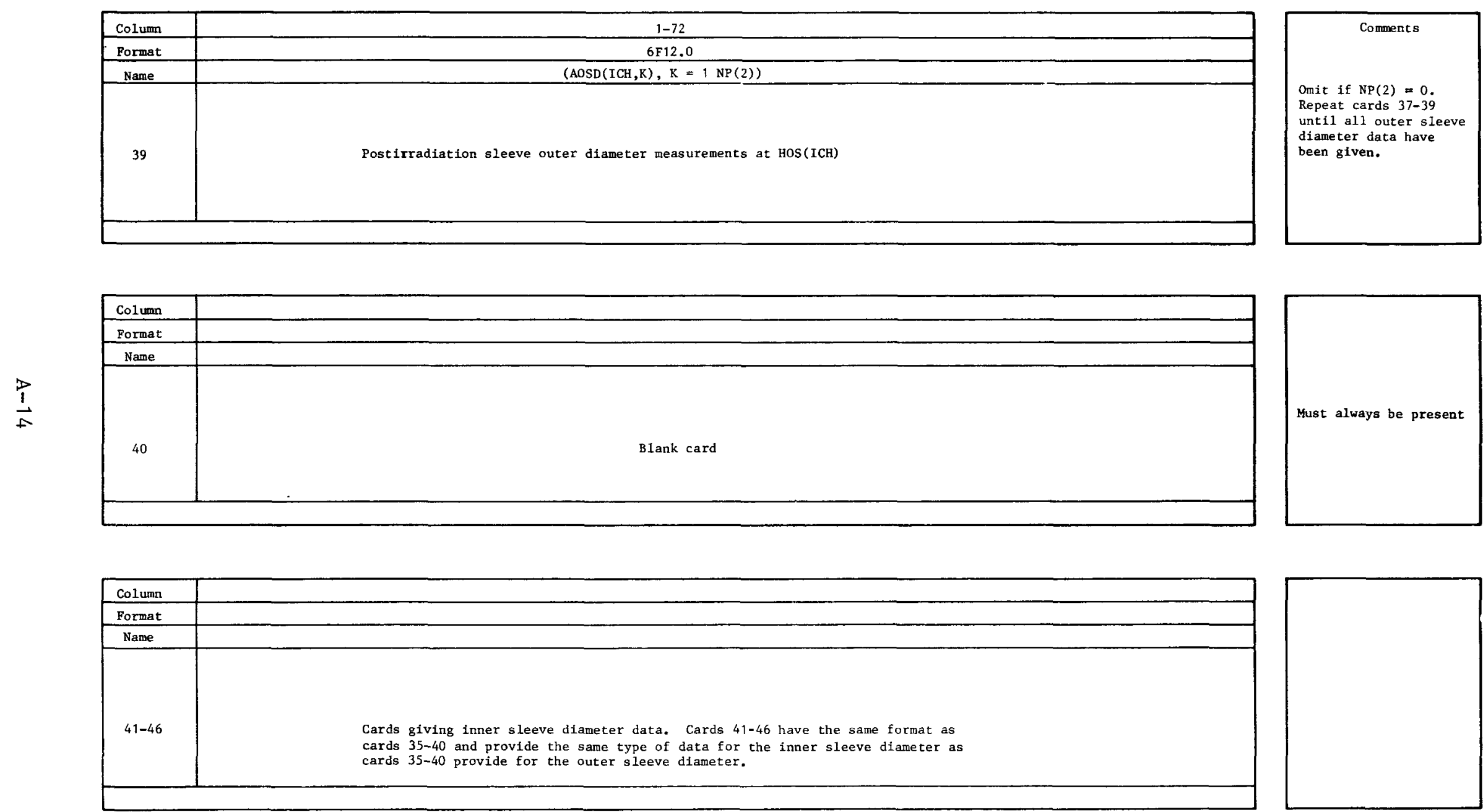


\begin{tabular}{|l|c|}
\hline Column & $1-80$ \\
\hline Format & CARD \\
\hline Name & \\
\hline 47 & $\begin{array}{l}\text { Comment cards giving genera1 information regarding fue } 1 \\
\text { stack length data. }\end{array}$ \\
\hline
\end{tabular}
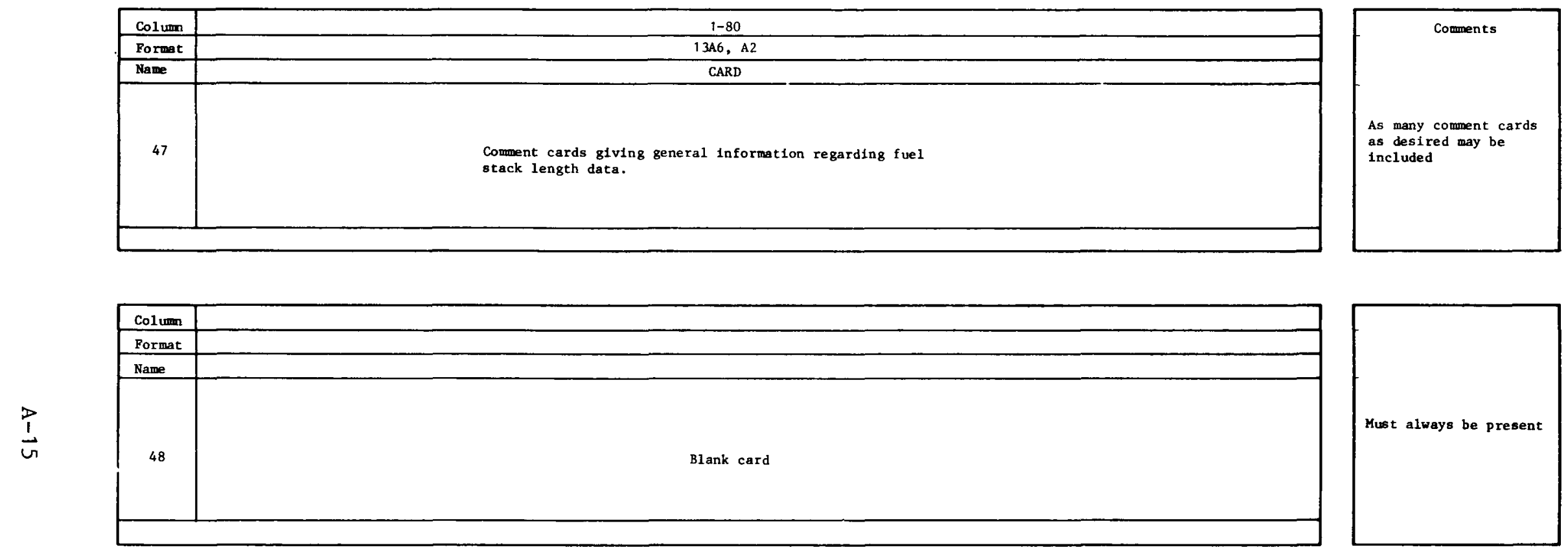

\begin{tabular}{|c|c|c|c|c|c|}
\hline Column & I-6 & $7-12$ & $13-24$ & $25-36$ & \\
\hline Format & I6 & I6 & F12.0 & F12.0 & \\
\hline Name & IB & IH & FSL(IB,IH, 1) & FSL(IB,IH,2) & \\
\hline 49 & $\begin{array}{l}\text { Fuel body to } \\
\text { wh1ch fuel } \\
\text { stack belongs }\end{array}$ & $\begin{array}{l}\text { Fuel hole to } \\
\text { wh1ch fuel } \\
\text { stack belongs }\end{array}$ & $\begin{array}{l}\text { Preirradiation } \\
\text { fuel stack } \\
\text { length meas- } \\
\text { urement (see } \\
\text { Section 1.1.6) }\end{array}$ & $\begin{array}{l}\text { Postirradiation } \\
\text { fuel stack } \\
\text { length meas- } \\
\text { urement (see } \\
\text { Section 1.1.6) }\end{array}$ & \\
\hline
\end{tabular}

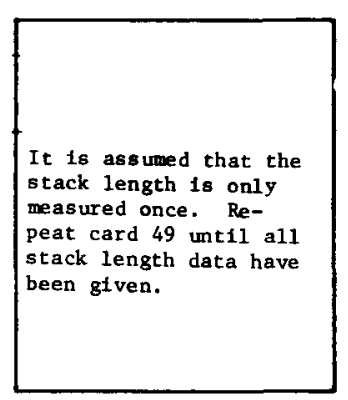



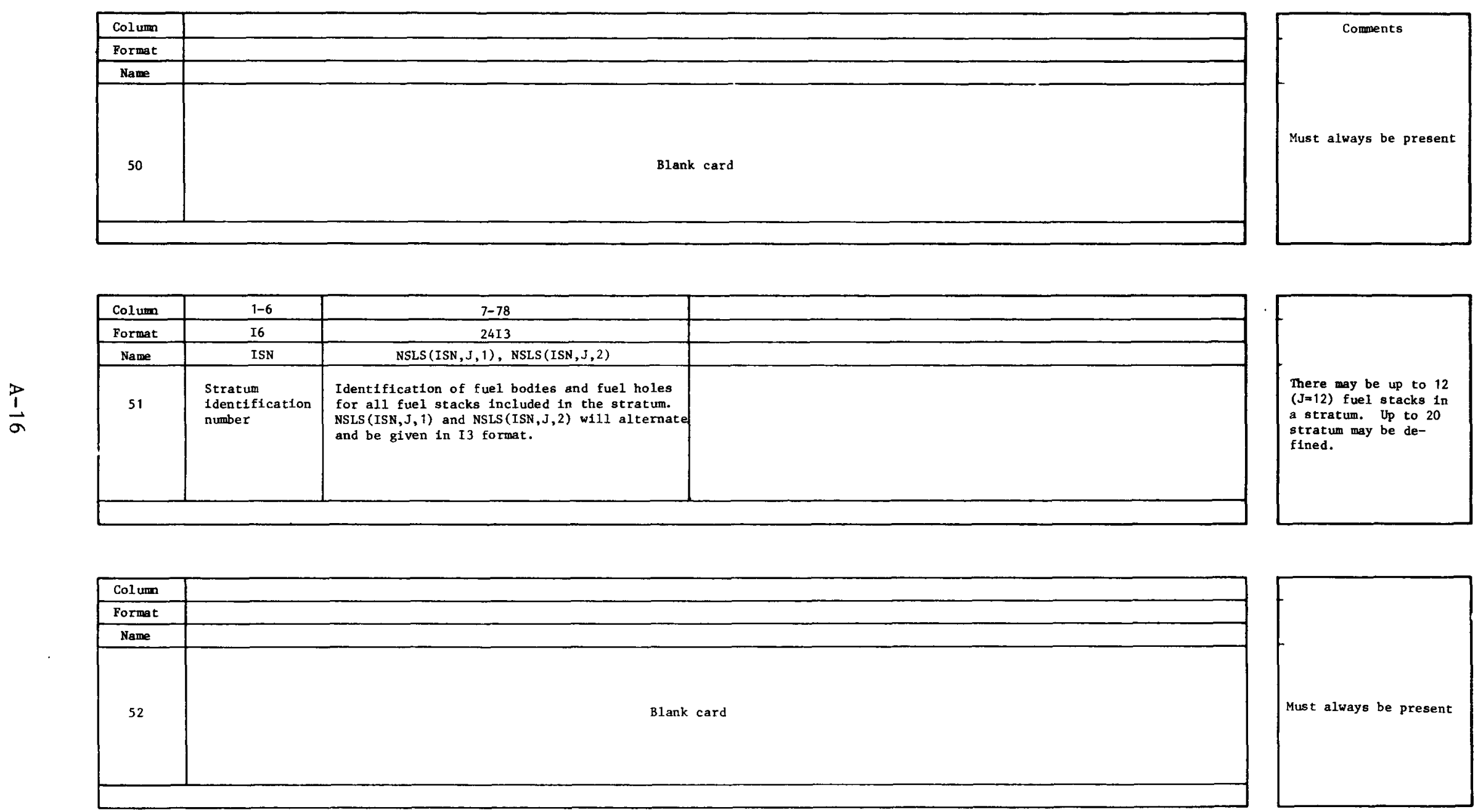


\begin{tabular}{|c|c|}
\hline Columa & $1-80$ \\
\hline Format & \\
\hline Name & CARD \\
\hline 53 & $\begin{array}{l}\text { Comment cards giving general information regarding fuel hole } \\
\text { plenum length data. }\end{array}$ \\
\hline
\end{tabular}
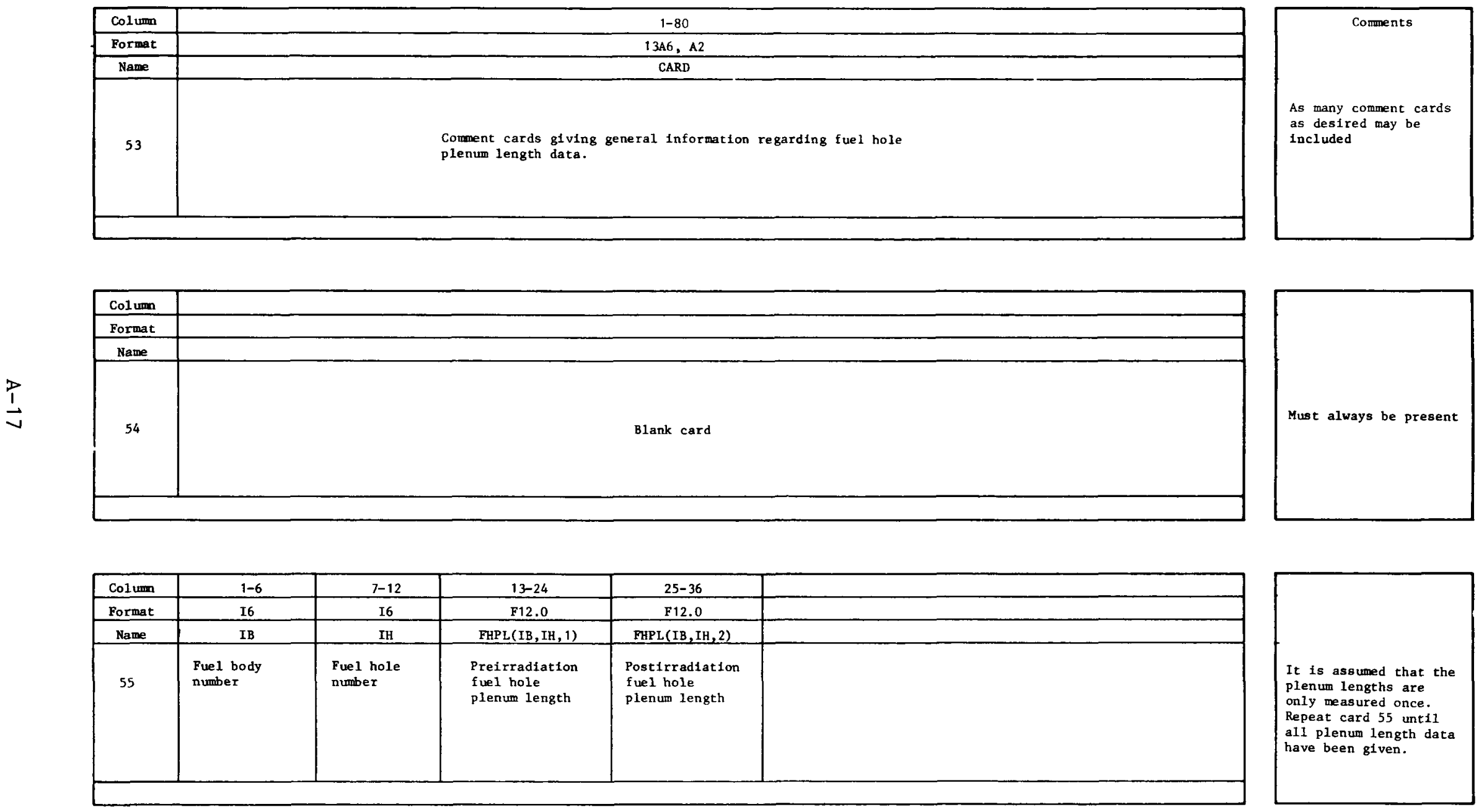

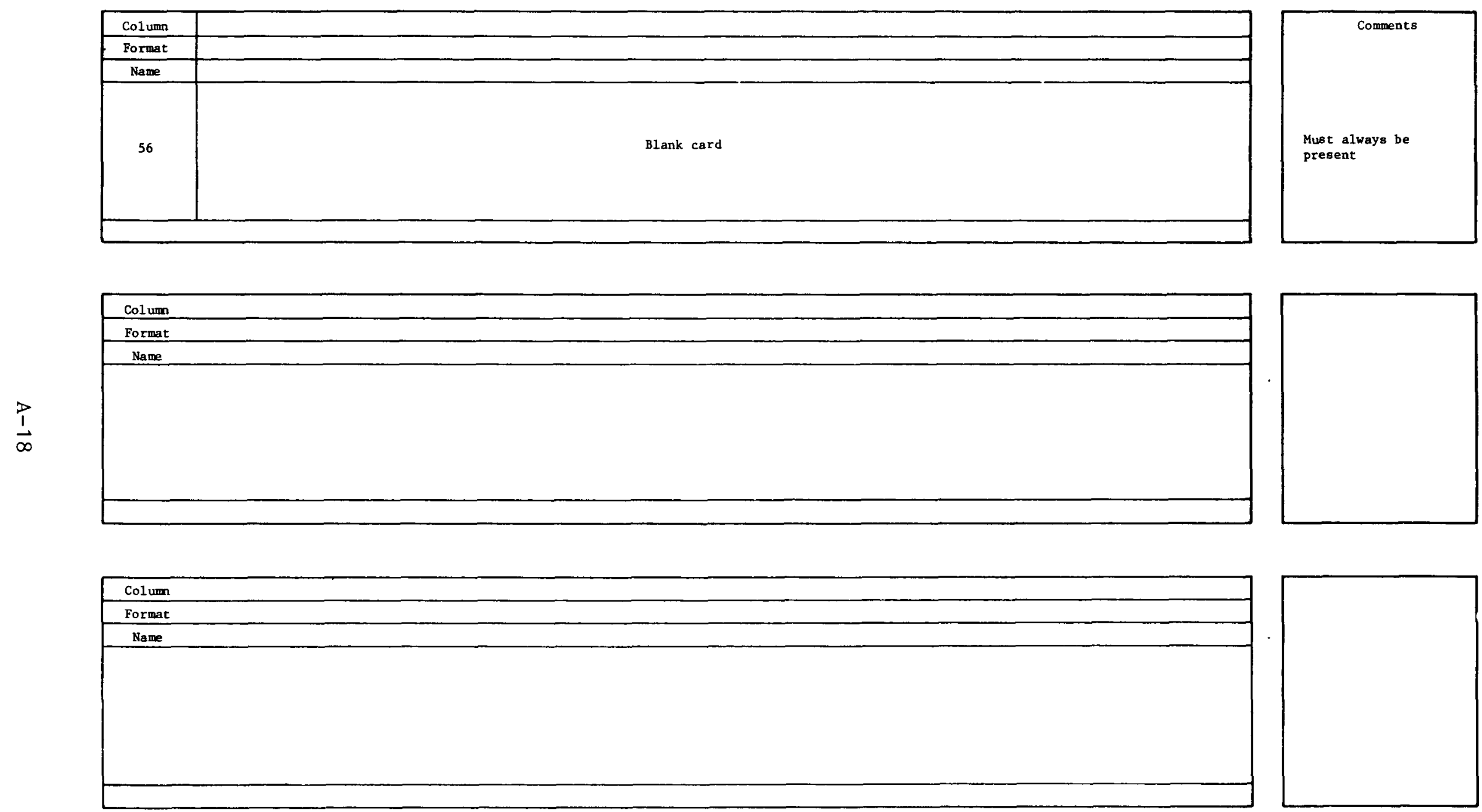

$\bullet$ 
APPENDIX B

STAT SAMPLE PROBLEM 

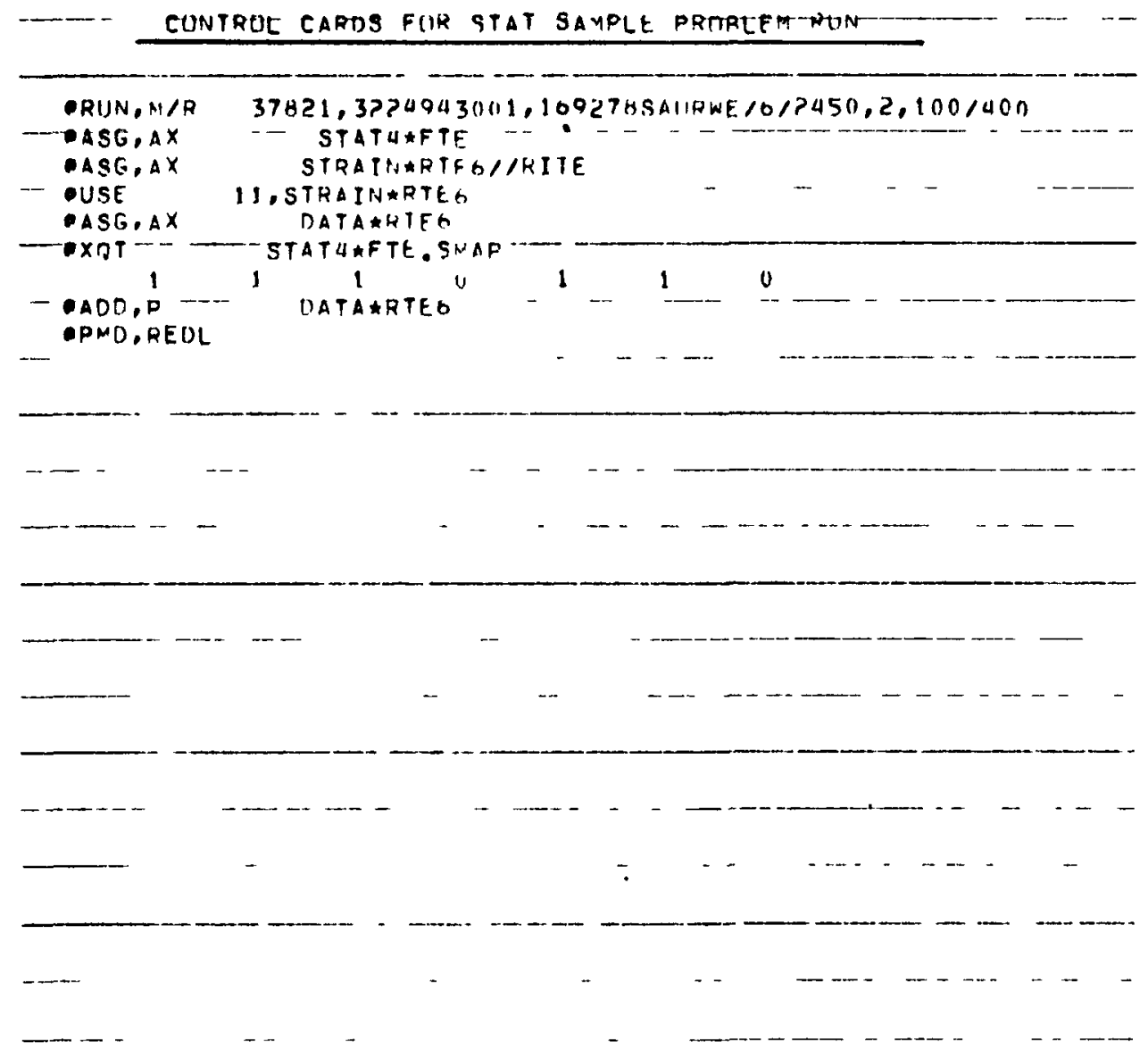


\section{INPUT DATA FILE FOR STAT SAMPLE PROBLEM RUN}

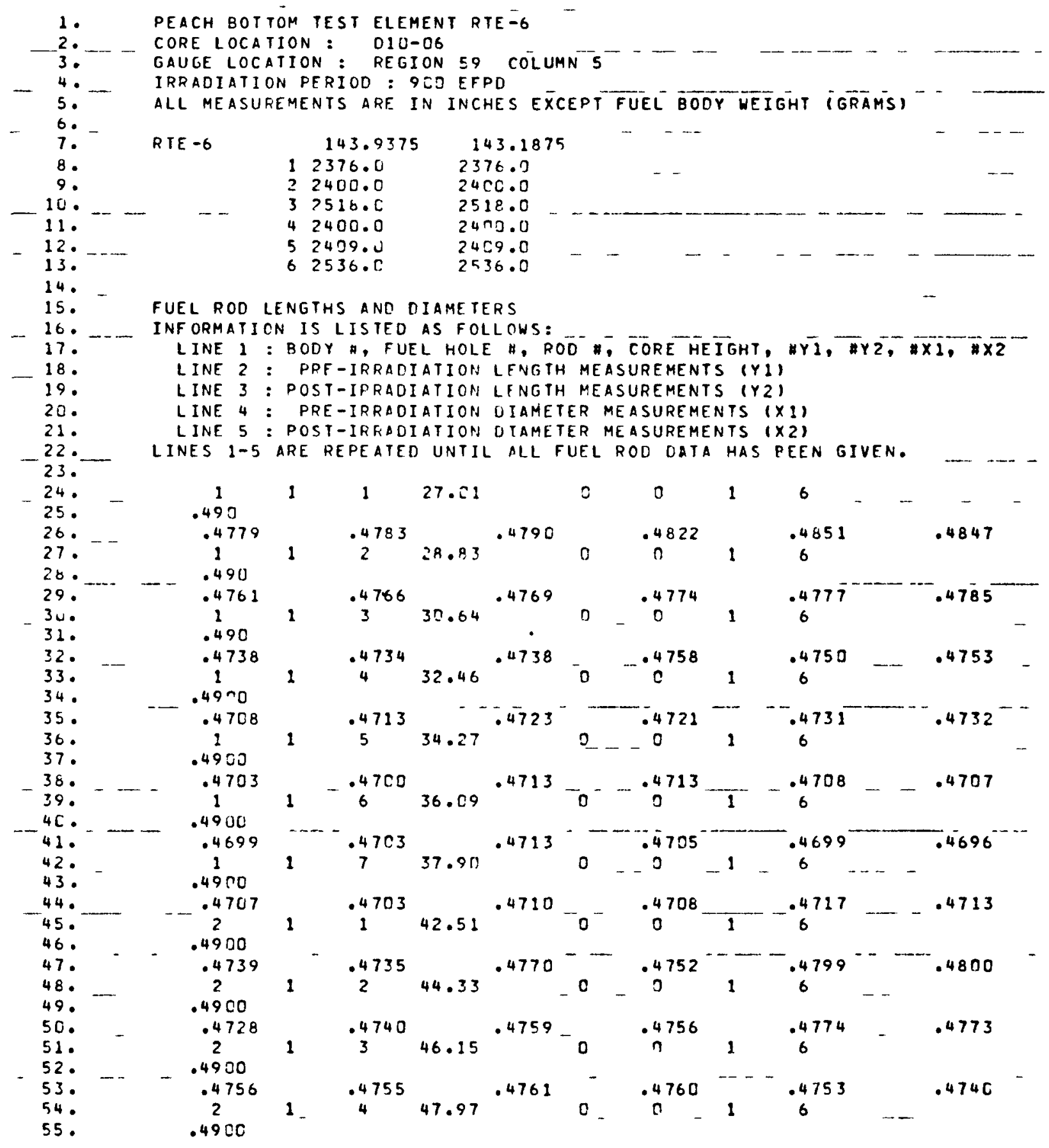




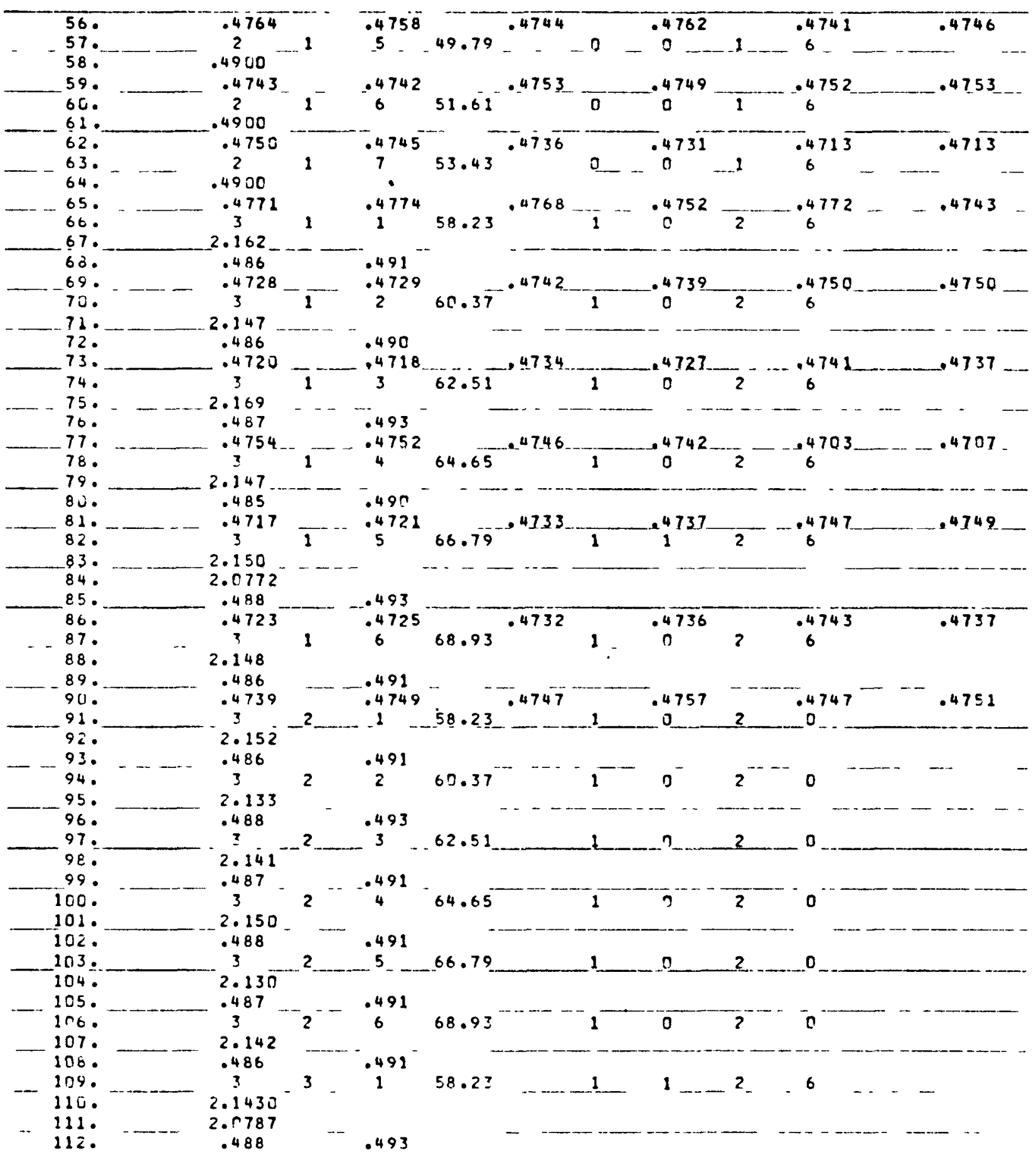




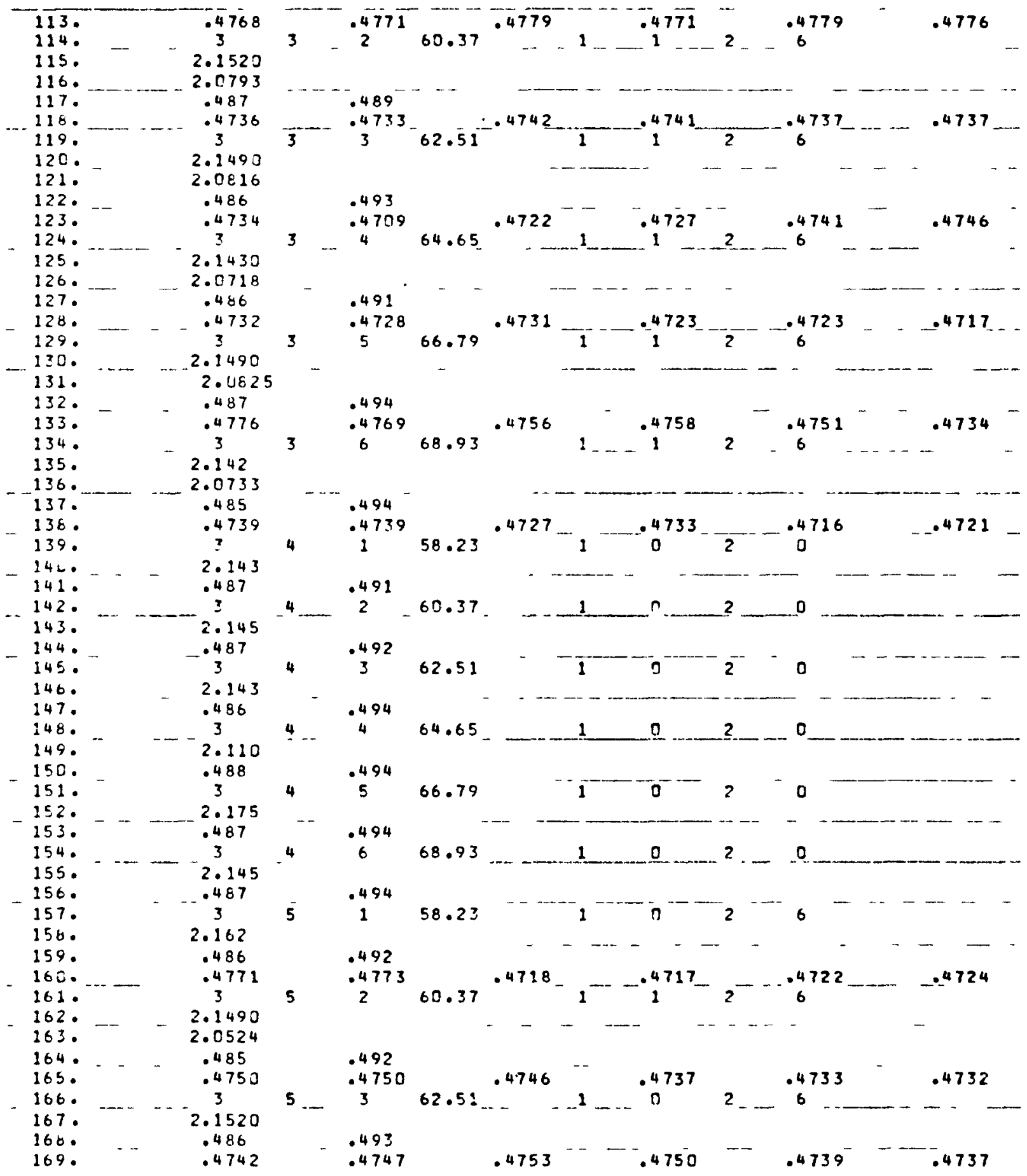




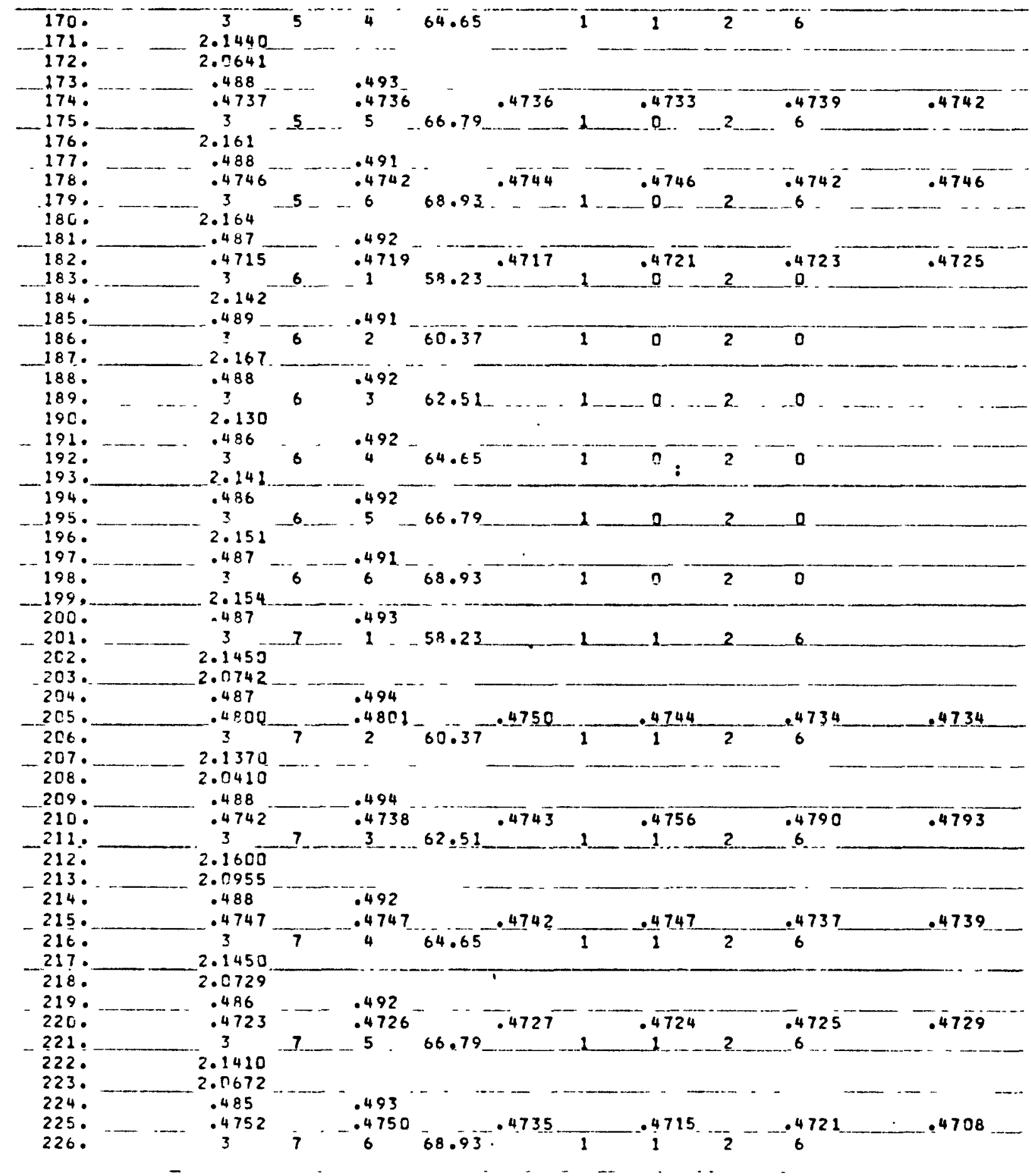




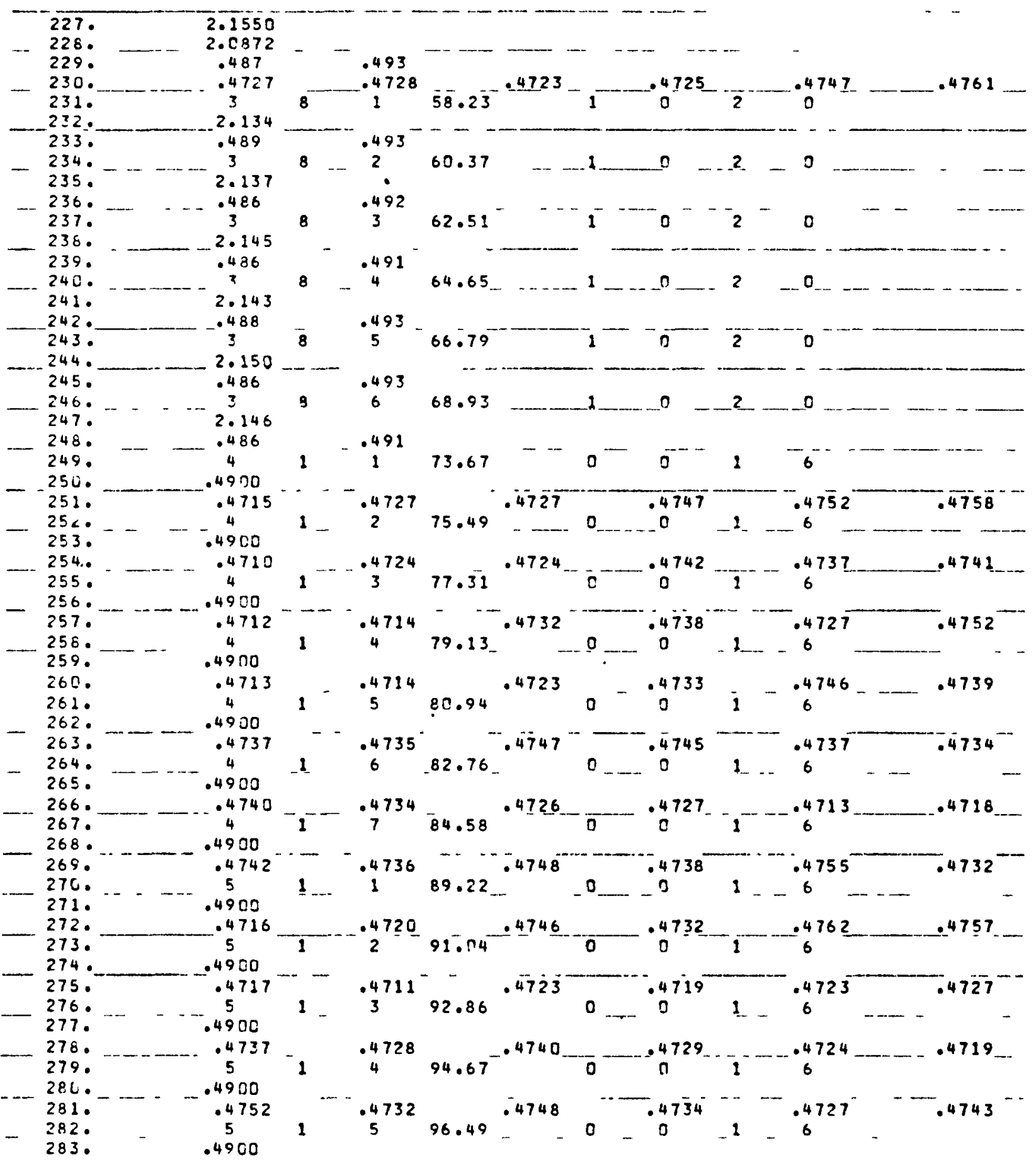




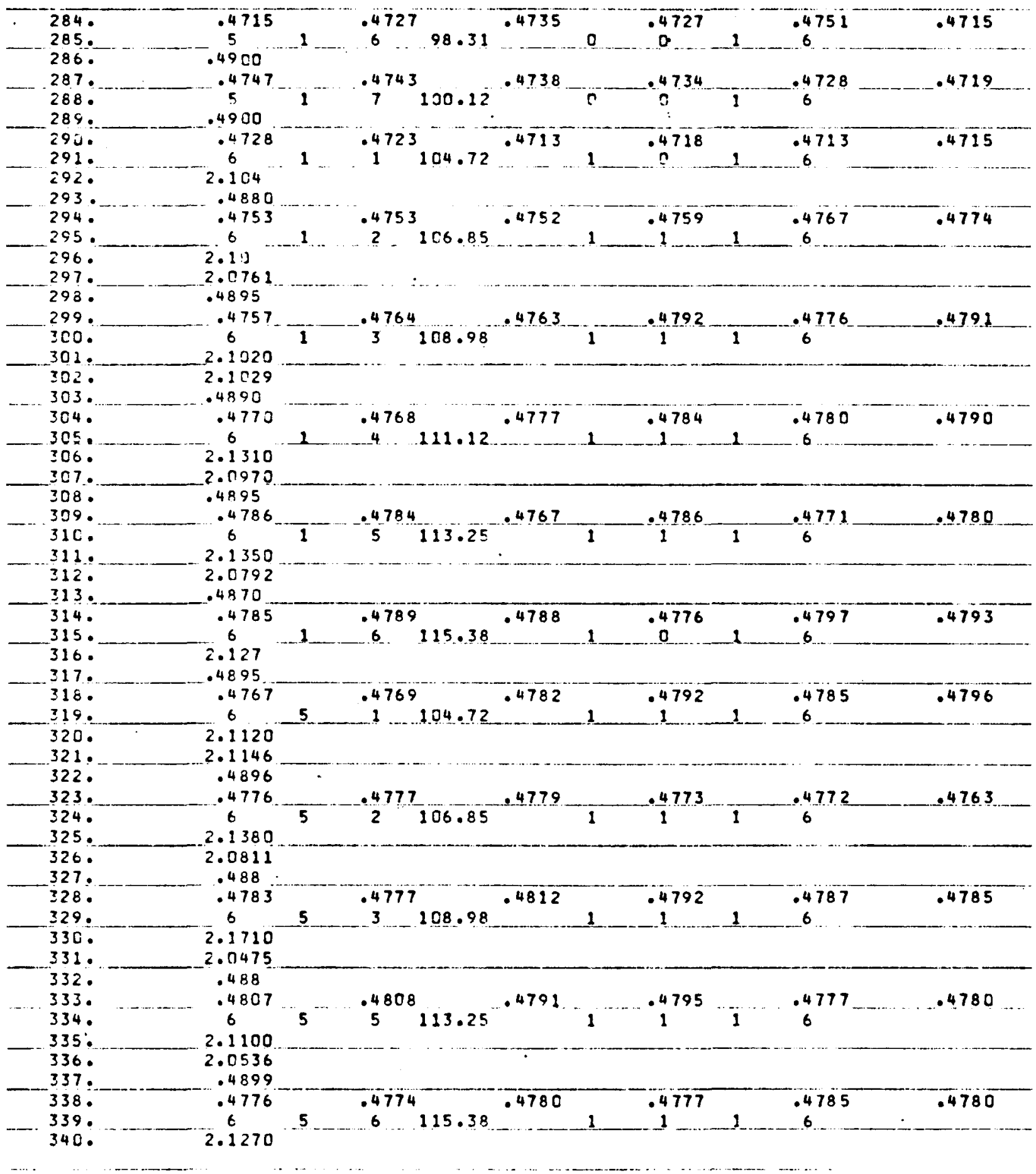




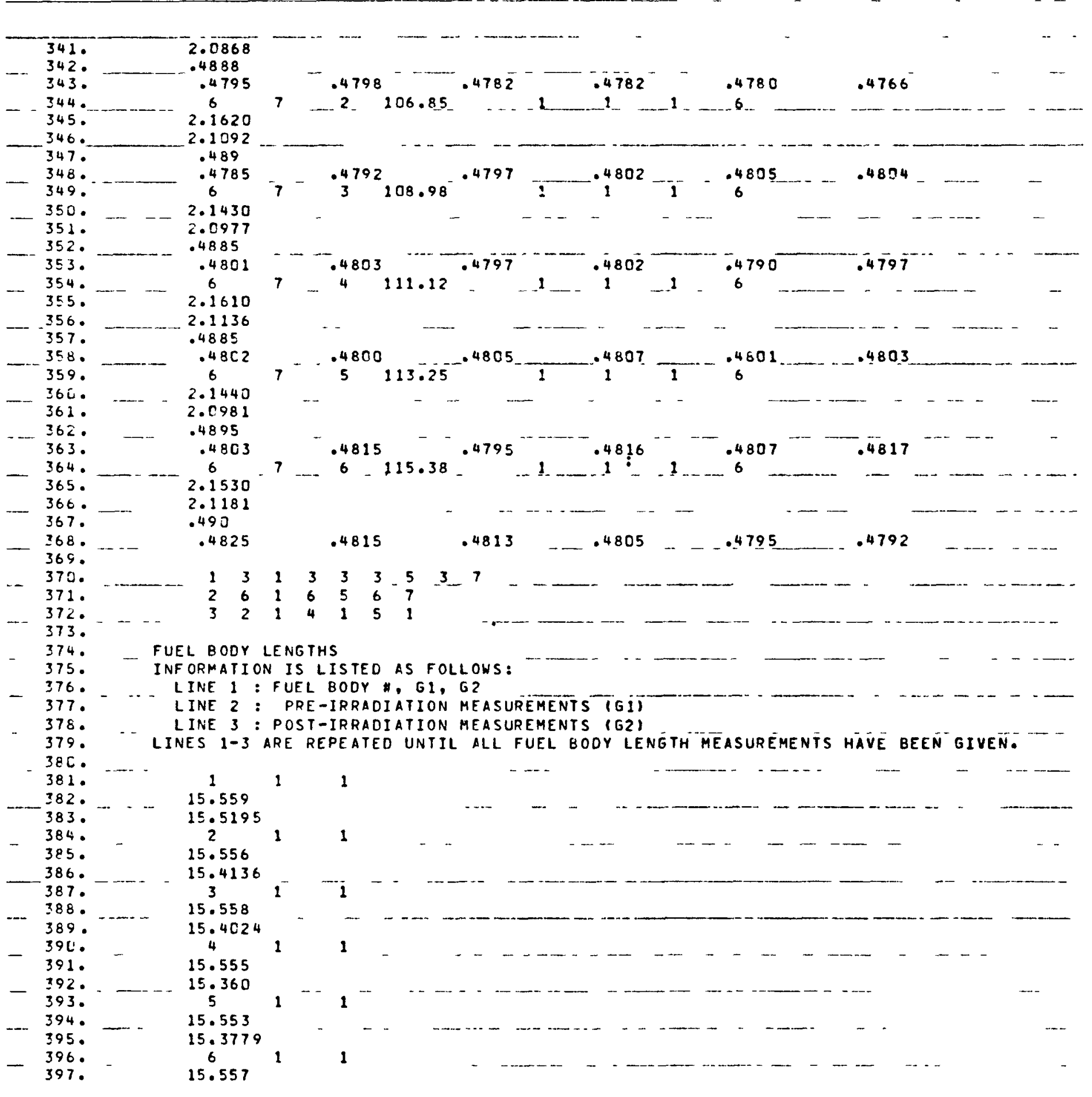


398 .

399.

400 .

401.

402 .

403.

404 .

4 C5.

$4 C 6$.

407 .

408 .

409 .

$41 \mathrm{C}$.

411.

412 .

413.

414.

415.

416.

417.

418 .

419.

420 .

421.

422 .

423.

424 .

425 .

426.

427 .

428 .

429 .

$43 \mathrm{C}$.

431.

$4 \geq 2$.

433.

434 .

435 .

436.

437 .

438 .

439.

440 .

442.

442.

443.

444.

445 .

446 .

447 .

446 .

449.

450 .

451 .

452 .

453 .

454 .

$15.476 \overrightarrow{9}^{-}$

FUEL BOOY DIAMETERS

POST-IRRADIATION DIAMETERS MEASURED ACROSS HOLES_165_._367

INFORMATION IS LISTED AS FOLLOWS:

LINE 1 : FUEL BOOY \#, CORE HEIGHT, \#X1, \#X2

LINE 2 : PRE-IRRADIATION MFASUPEMENT $(\times 1)$

LINE 3 : POST-IRRADIATION MEASUREMENT $(\times 2)$

LINES 1-3 ARE REPEATED UNTIL ALL FUEL BODY DIAMETER MEASUREMENTS have BeEN GIVEN

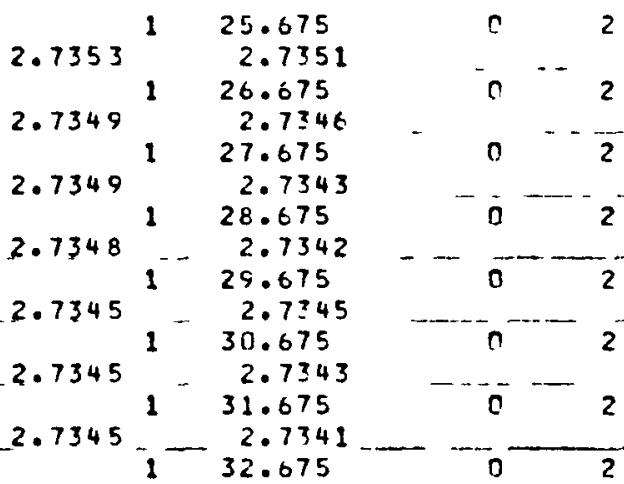

2.733313

$33.675-\mathrm{C}^{-}-2$

$2.7335 \ldots 2.7329$

2.7330 .34 .675

2.7327
35.675

$2.7331-2.7327$

$1^{-} 36.675$

$2.7332-2.7328$

$\begin{array}{rrr}2.7326 & 37.675 \\ 2.7325\end{array}$

138.675

$\begin{array}{rr}2.7315 \ldots & 2.7308\end{array}$

2.7313139 .675

$\overrightarrow{1}-40.425$

$2.740-41.225$

$2.739-2.7 ? 9$

$2.7264 \quad 2.7274$

$2.7265^{-\frac{2}{4}-42.225}-2.7268$

$2.7265^{2}-43.225$
2.7282

$2-44.225$

$2.7274 \quad 2.7273$

$\begin{array}{rr}2.7271^{2} & 45.225 \\ 2.7265\end{array}$

2. 46.225

$2.7271 \quad 2.7258$

2.725827 .225

$-2$

2.7251

0
0
0
0
0
0

$\ldots+\ldots$ 


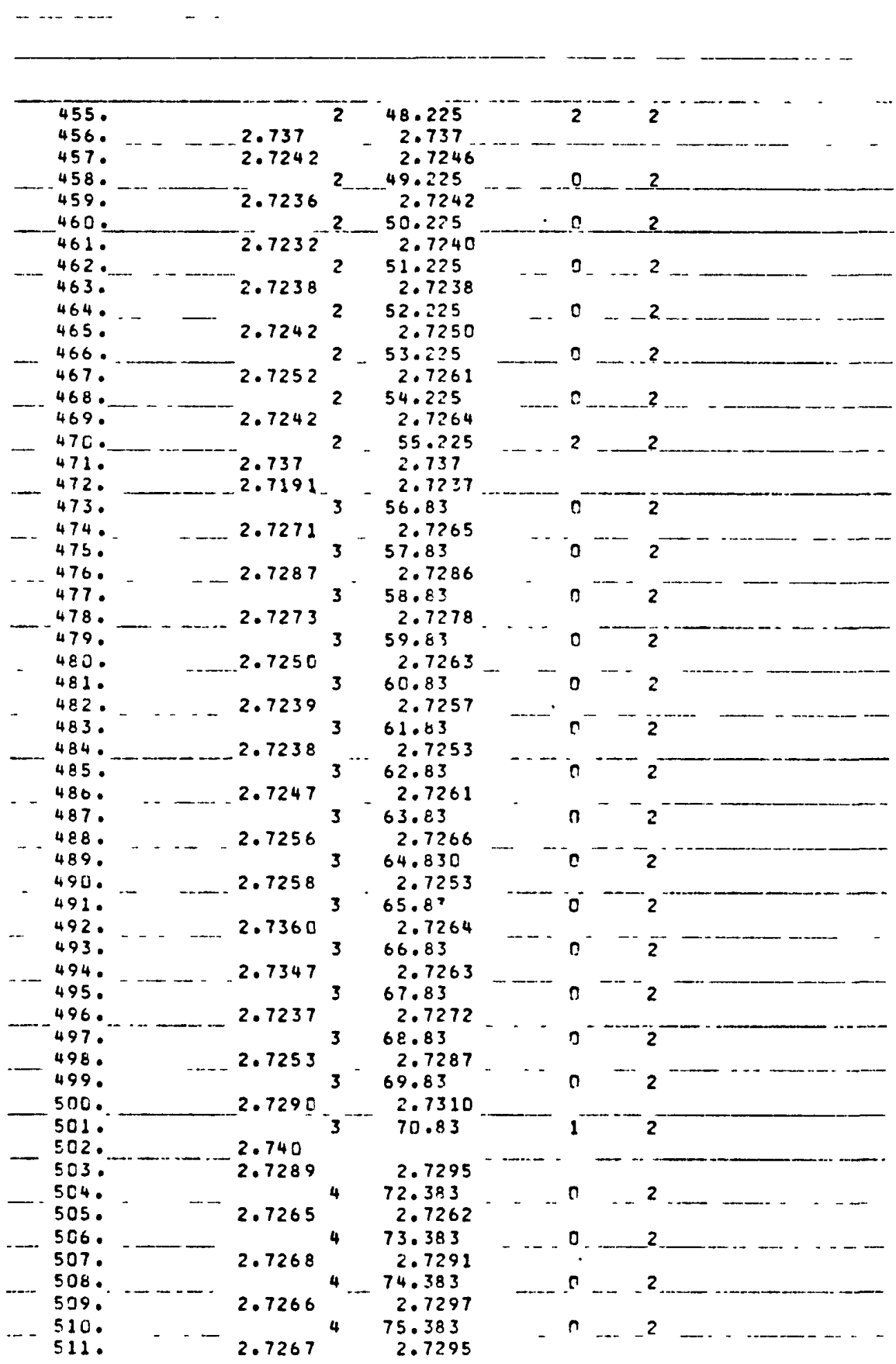




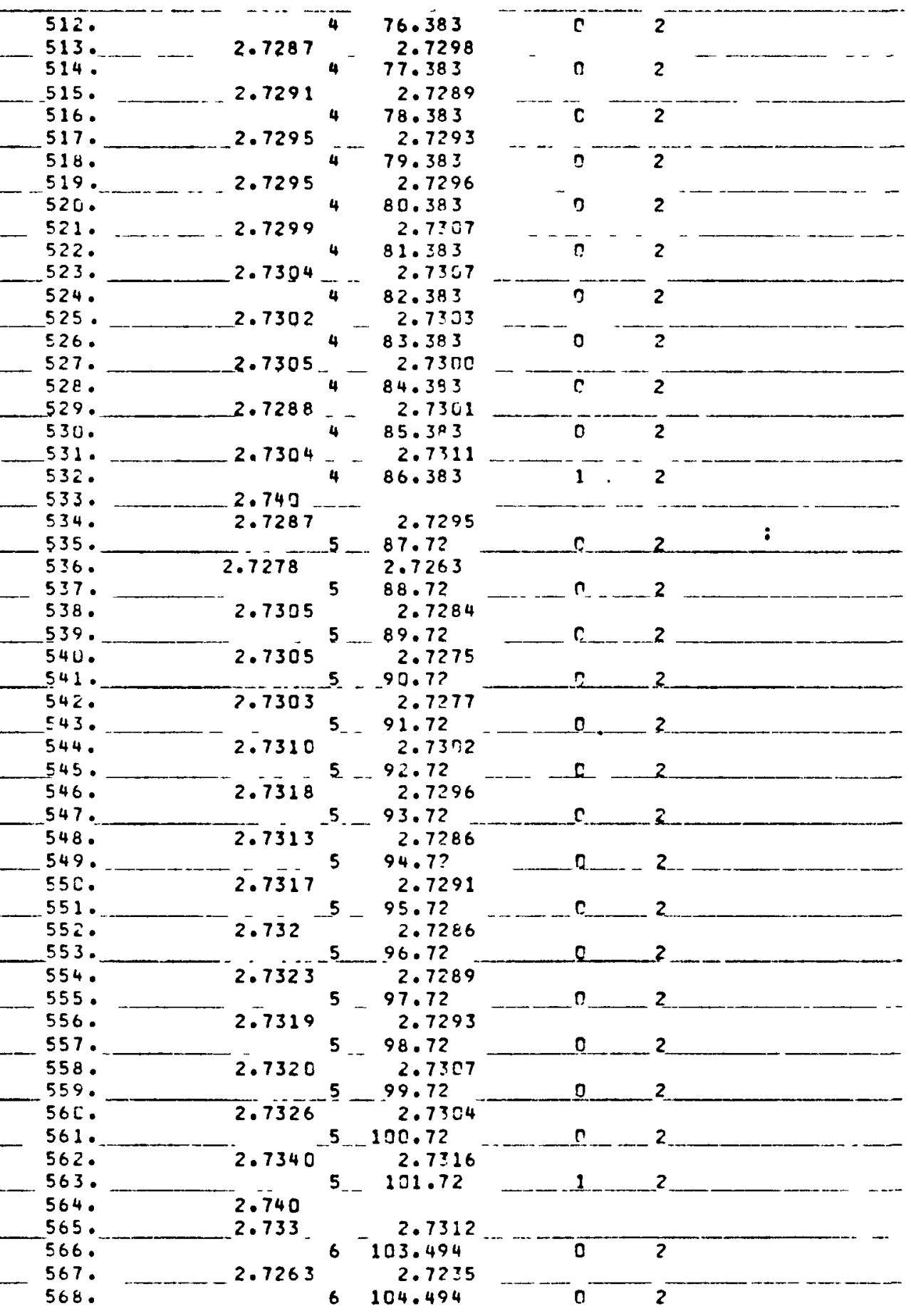




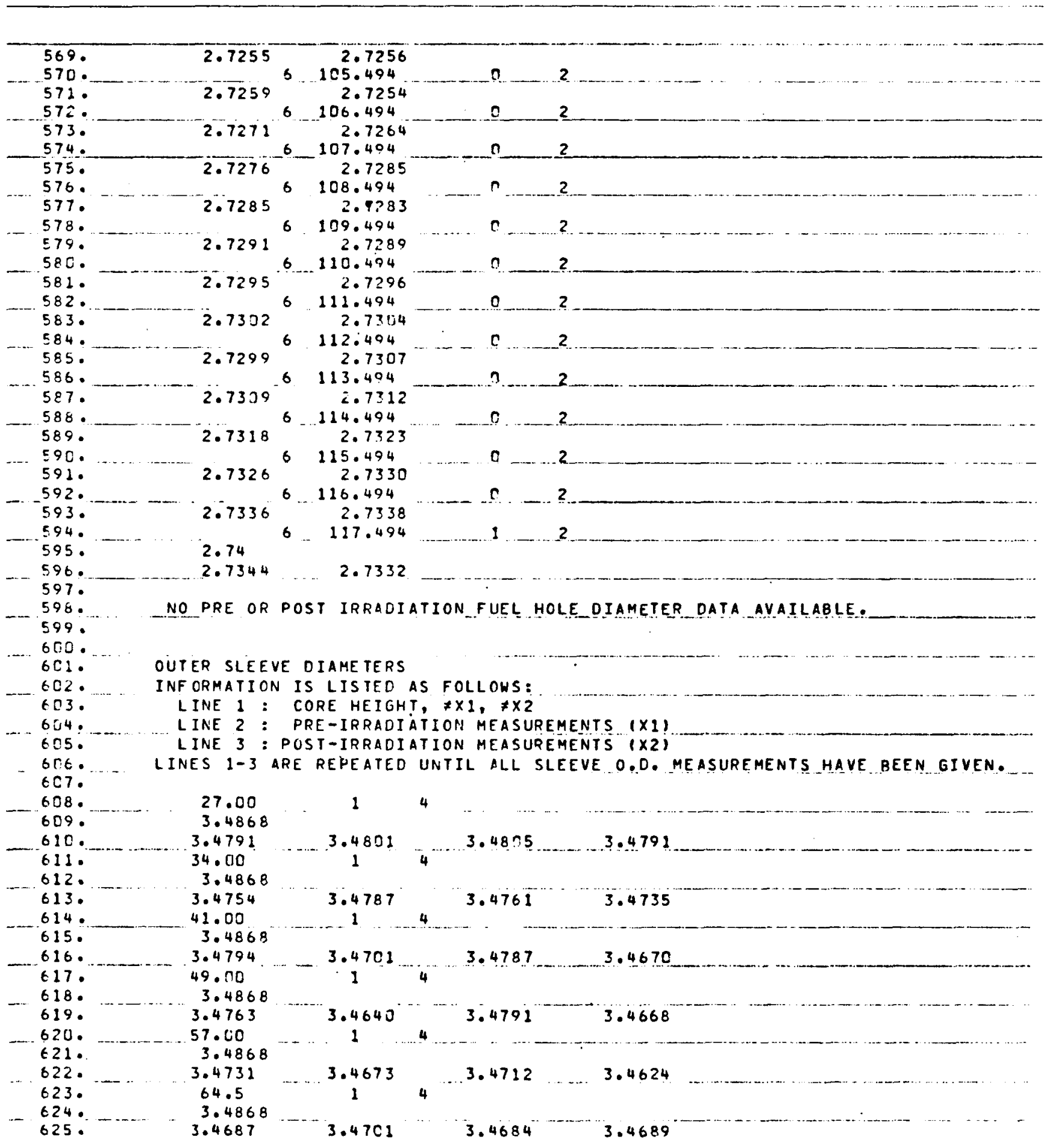




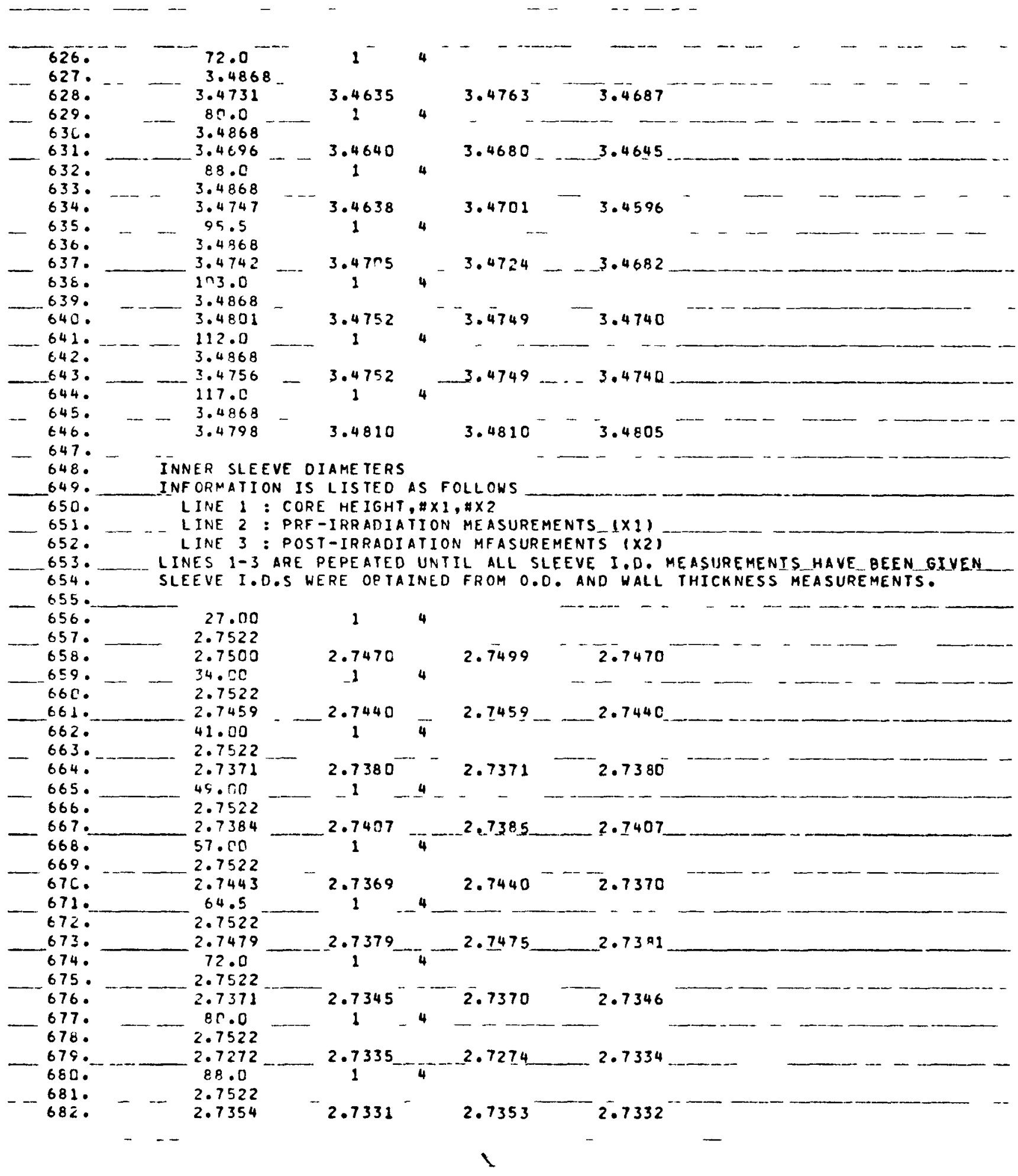




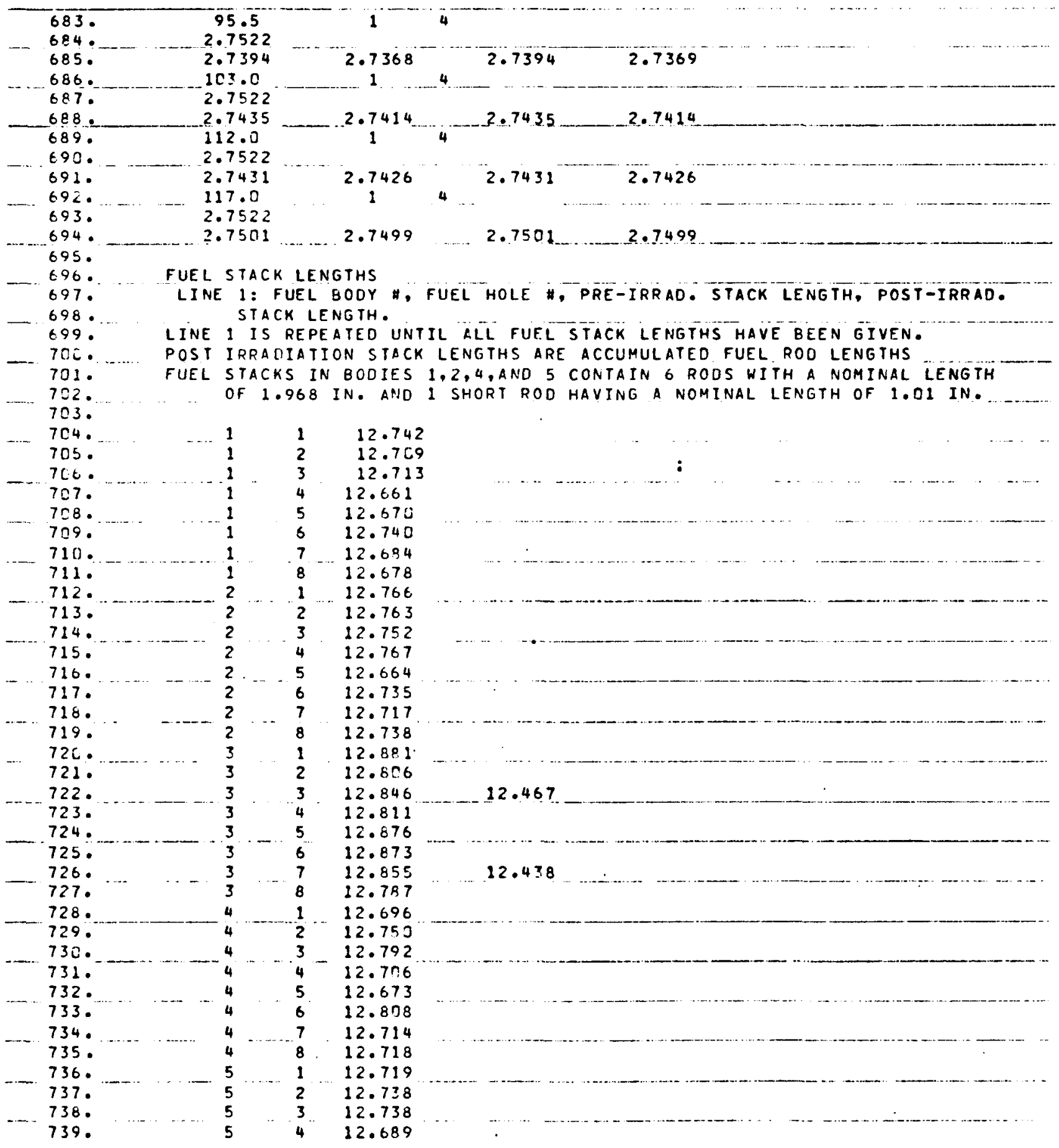




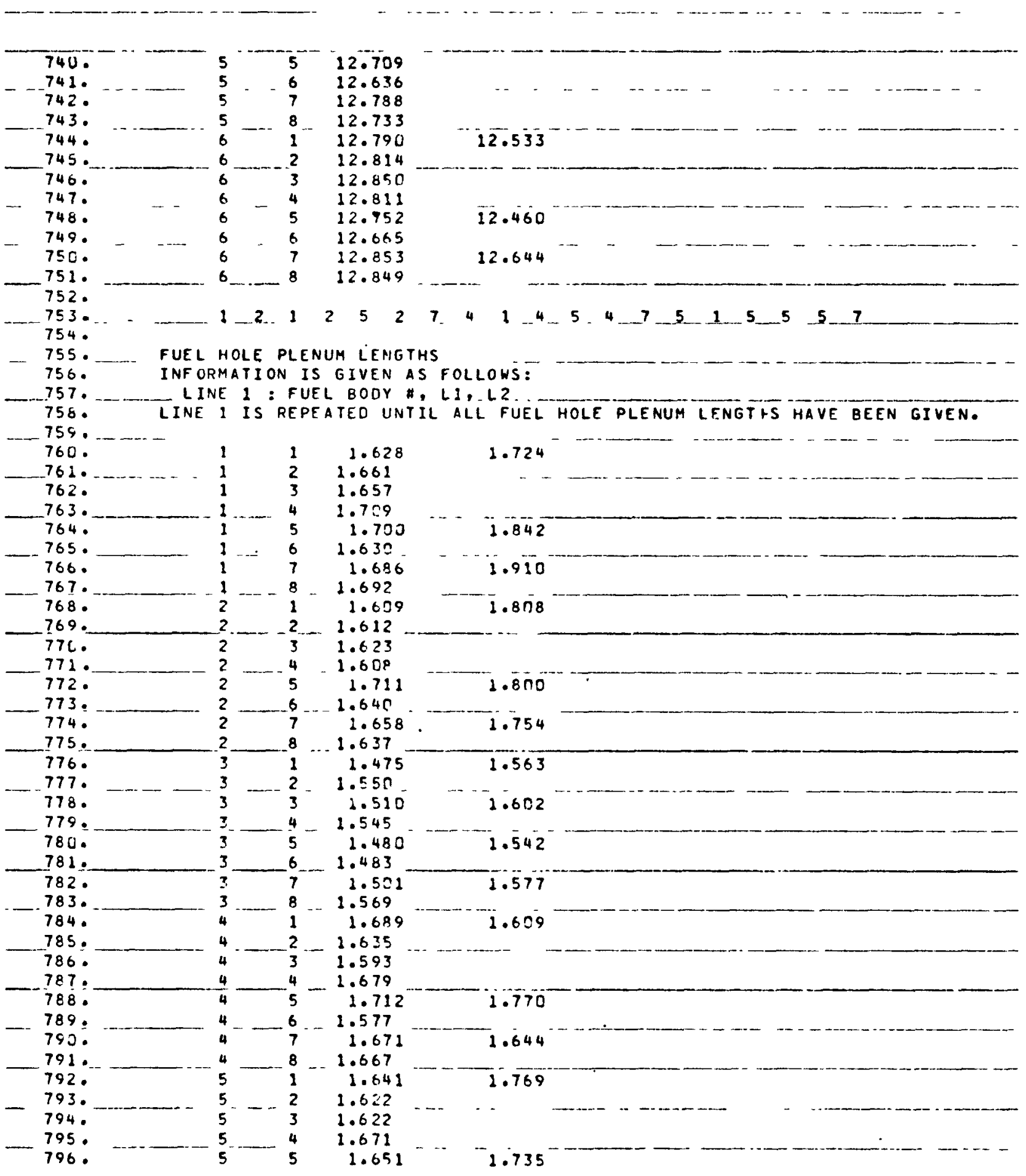




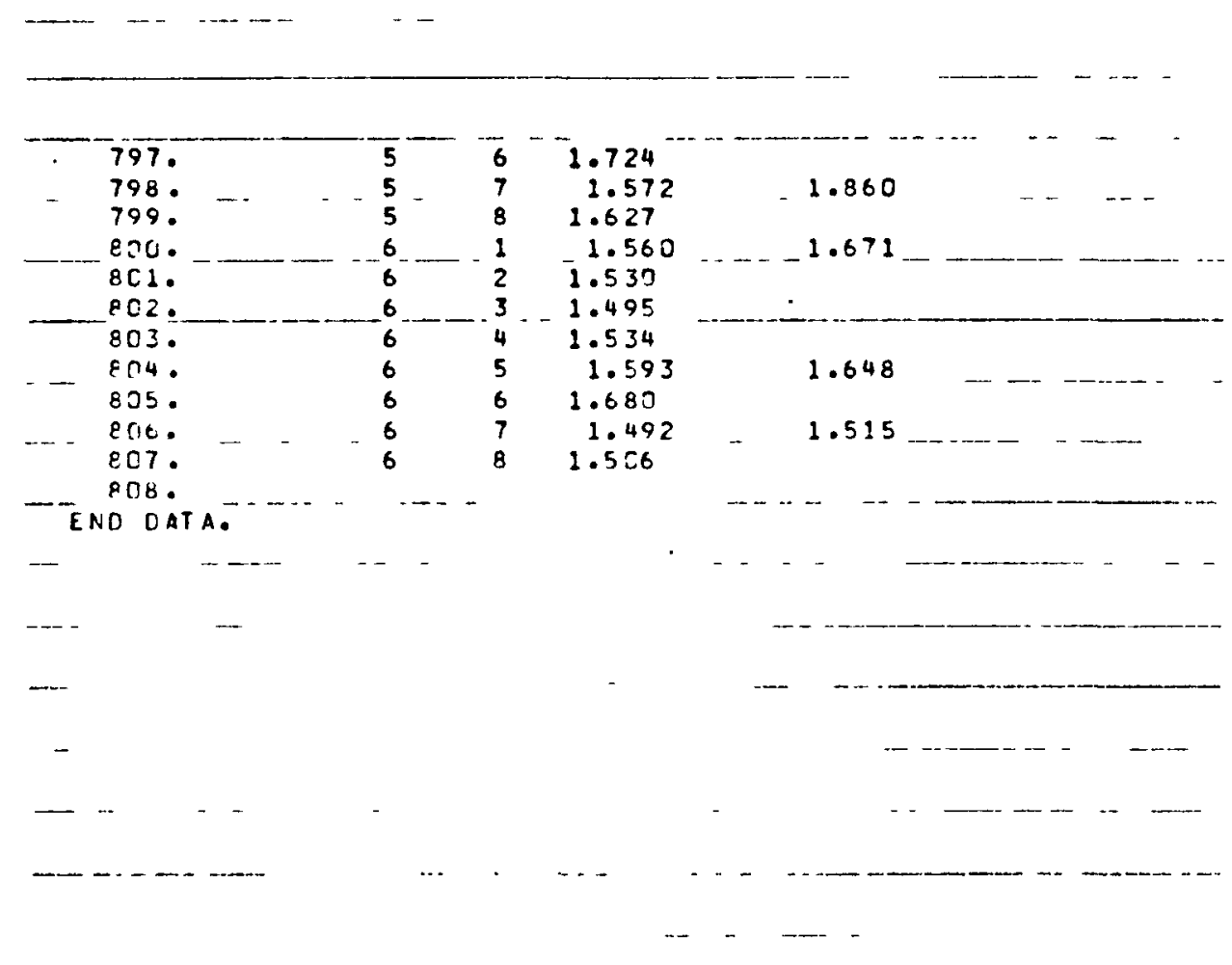




\footnotetext{
\# indicates number

* indicates letter

1. *1 indicates preirradiation

2. *2 indicates postradiation

3. Y非 fuel rod length

4. G非 fuel body length

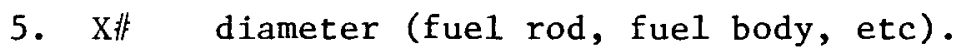

6. $\mathrm{N}^{*}$ 非 number of measurements

7. $S *$ sample random error for $*=X, Y$, or $G$

8. $E^{*}$ 非 combined random error for $*=X, Y$, or $G$

9. *21 represents analysis function $* 2-* 1$

10. $S * 21$ sample random error for analysis function $* 2-* 1$

11. $D * 21$ total error $(2 \sigma)$ for analysis function $* 2-* 1$

12. UY fuel rod axial strain - analysis function $(Y 2 / Y 1)-1$

13. UX radial strain - analysis function $(X 2 / X 1)-1$

14. UG fuel body axial strain - analysis function (G2/G1) - 1

15. $\mathrm{V}$ average strain - analysis function ( $(U Y$ or $U G)+U X) / 2$

16. W anisotropy - analysis function ((UY or UG)/UX) $\times 100$ '

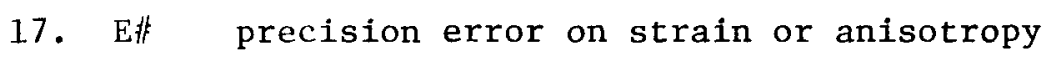

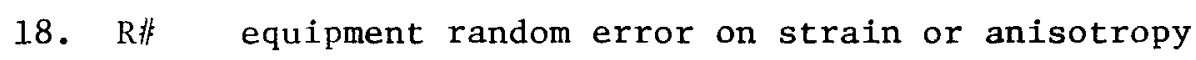

19. S非 sample random error on strain or anisotropy

20. EP非 combined random error on strain or anisotropy

21. D非 total error $(2 \sigma)$ on strain or anisotropy

22. L

23. P非 fuel hole plenum length

24. UL fuel stack axial strain - analysis function (L2/L1) - 1

25. $\mathrm{G} 2$ ' $\mathrm{G} 2 \times[(\mathrm{L} 1+\mathrm{P} 1) / \mathrm{G} 1]$

26. LI indirect fuel stack length ( $\left.\mathrm{LI}=\mathrm{G} 2^{\prime}-\mathrm{P} 2\right)$

27. ULI fuel stack axial strain calculated from the indirect fuel stack length - analysis function (LI/LI) - 1

28. $E^{(a)}$ precision error
} 
SAMPLE PROBLEM RESULTS

TOTAL ELEMENT DATA, TEST ELEMENT RTE-G

PARAMETER VALUE

PRE-IPRADIATION LENGTH (LI) (IN) 143.9375

POST-IRA ADIATICN LENGTH (L2) (IN) $\$ 43.1875$

DIFFERENCE (LZ-LL) (IN)

STRAIN (L2/L:-I) (Z)

\section{ACCURACY}

.03125

.03125

. 06250

.04332

FUEL BOOY WEIGHT, TEST ELEMENT RTE-6

\begin{tabular}{|c|c|c|c|}
\hline \multirow{3}{*}{$\begin{array}{l}\text { FUEL } \\
\text { BODY }\end{array}$} & & \multicolumn{2}{|c|}{ PRE-IRRADIATI ON } \\
\hline & & WEIGHT & ACCURACY \\
\hline & & G & G \\
\hline$!$ & & 2376.03 & 1.2000 \\
\hline 2 & & 2400.00 & 1. 0 uco \\
\hline 3 & & 2518.40 & $1.70=0$ \\
\hline 4 & & 2400.60 & $1.0 \cup 00$ \\
\hline 5 & - & 2459.03 & 1.0500 \\
\hline 6 & & 2536.43 & 1.0000 \\
\hline
\end{tabular}

\begin{tabular}{|c|c|}
\hline \multicolumn{2}{|c|}{ POST-IRRADIATION } \\
\hline WEIGHT & $\begin{array}{c}\text { ACCURACY } \\
G\end{array}$ \\
\hline $\begin{array}{l}2376.00 \\
2400.00 \\
2519.00 \\
2450.00 \\
2459.00 \\
2536.00\end{array}$ & $\begin{array}{l}1.0200 \\
1.0000 \\
1.0000 \\
1.0000 \\
1.0000 \\
1.0000\end{array}$ \\
\hline
\end{tabular}

DIFFERENCE

WEIGHT ACCURACY

$G$

- $\mathrm{CO}$

.00

.00

.00

.50

.00
G

2.2000

2.0030

2. 0000

2. 7000

2. 0000

2.0000
REL . CHANGE VALUE ACCURACY $x$ .0000 .0500 - 0000 .0000 .0000 .0000
* .0842 .0833 .0794 - 0833 .0830 .0789 


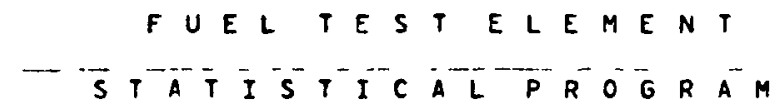

$\triangle A D D, P$

$$
\text { DATA } 1 .
$$

PEACH BOTTOM TEST ELEMEVT RTE-6

CORE LOCATION : 010-OB

GAUEE LOCATION: REGION 59 COLUMN 5

I RRAUIATION PERIOD: 9 CO EFPO

ALL MEASUREMENT'S ARE IN INCHES EXCEPT FUEL BOOY WEIGHT (GRAMS) 
PRECISION:

LENGTH $=-. D O O: C$

ECUIPUE

LEVTH $=0.0012$

\section{PRE - IRPAOIATIOP'}

$\begin{array}{cc} & \\ \text { FUEL RCO } & \text { LENGTH } \\ \text { COPE } & \text { OIARETER } \\ \text { HEIGHT } & \text { LEN + DIAM } \\ \text { IINI } & \text { ANISCTROPY } \\ 1-1-1 & Y \\ 27.01 & X \\ & (Y+X) / 2 \\ & Y / X\end{array}$

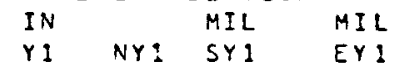

$\begin{array}{llll}Y 1 & N Y: & S Y 1 & E Y 1 \\ X 1 & N X 1 & S \times 1 & E X 1\end{array}$

$\begin{array}{llll}.0070 & 0 & .000 & .020 \\ .4900 & 1 & .000 & 1.0000\end{array}$

PRECISION:

LENGTH $=$. ONCIO

LIAMETER Z

LENGIH =

DIAMETER = - . $20: 5$

POST-IRRADIATION

II OIFFERENCE

II MYZ MIL MIL

$\begin{array}{llll}Y Z & N Y 2 & S Y 2 & E Y 2 \\ X 2 & N X 2 & S \times 2 & E X 2\end{array}$

IN MIL MIL
YZ SI SYZI OYZI

. $\operatorname{noce}$
.4812

.000

.000 $\times 215 \times 21 \quad 0 \times 21$

$1-1-2 \quad Y$ $\underset{\substack{Y \\(y+X) / 2}}{Y(X)}$

$1-1-3$
30.64

$y / X$

$.0000 \quad 0.000$

$\begin{array}{llll}.4900 & 1 & .000 & .000 \\ & & & \end{array}$

. 8000

-

.000000

$.030 \quad .000$

$\underset{\substack{Y \\(Y+X) \\ Y(X)}}{x}$

$(Y+X) / 2$
$Y / X$

$.0000 \quad 3.000 \quad .020$

.0000

.8

$$
\begin{array}{r}
1-1- \\
32.46
\end{array}
$$

$y$

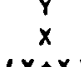

$\underset{(y+x) / 2}{x}$

$Y / X$

$1-1-5$
$34 \cdot 27$

$r$

.0000

.4900

900

1.090

03.030

$.000 \mathrm{C}$
$(y+X)$
$y / X$

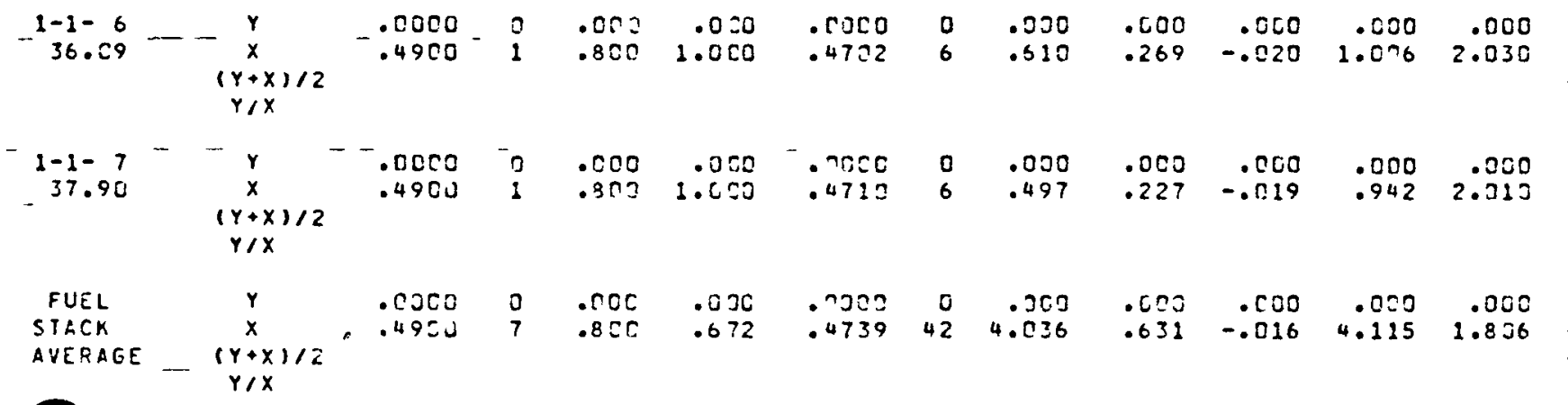

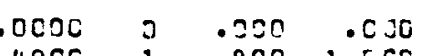
.4900

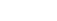


UEL R OOODOATA TESTELEMEN TRTEOG

\section{PRECISIONE}

FUEL B O DY Z FUEL HOLEI

DENGTHE .00010 LENGTH $=.00010$

EOUIPMENT RANOÓM ERRUR: ERUIPMENT RANDOOM ERROR

LENGTH $\equiv .00010$ - - LENGTH $=.00010$

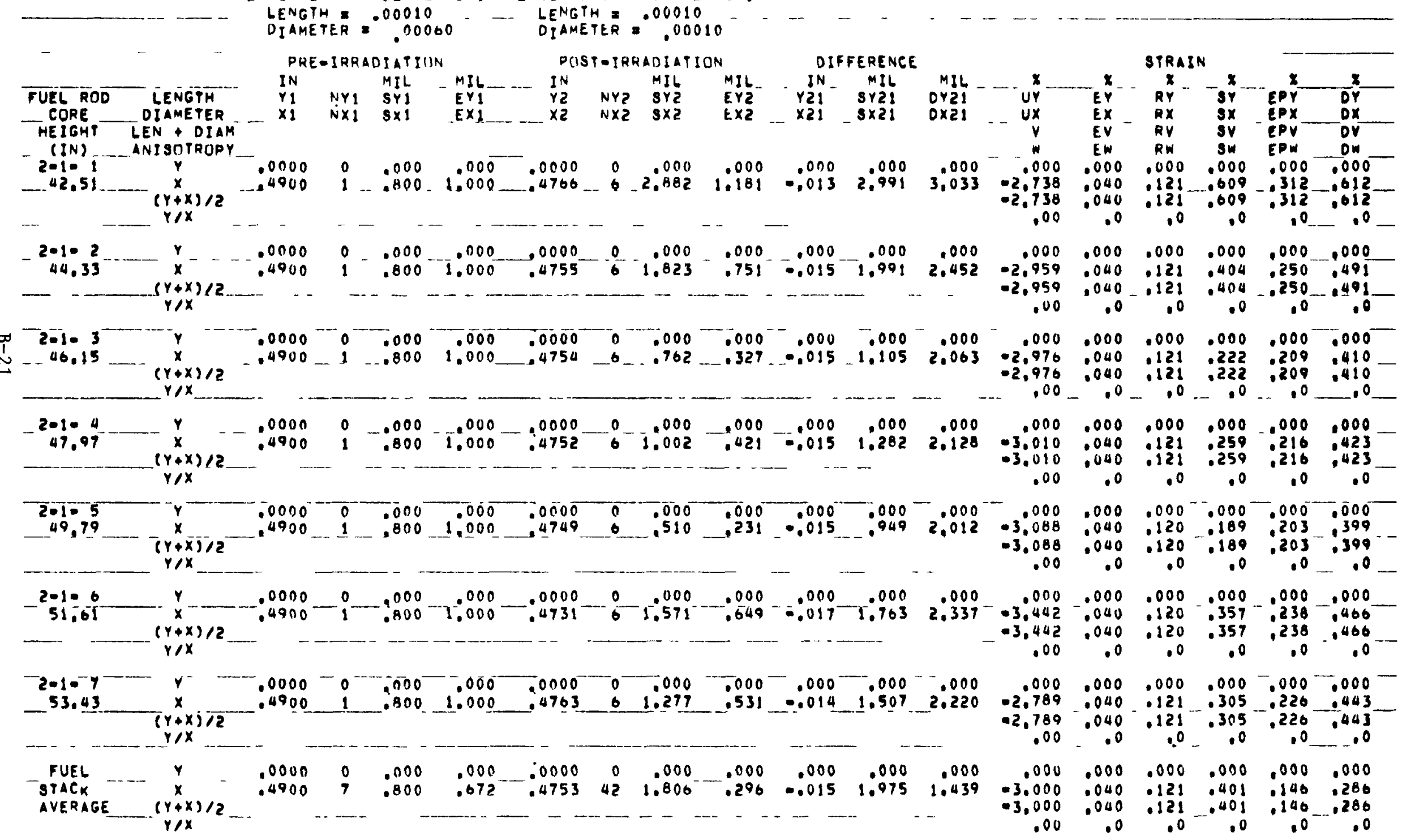


PRECISION:

LENGTH $=.00020$

COUIPMEMT RANDOM ERROR

LENGTH $=$.COD10

DIAMETEZ $=.03560$

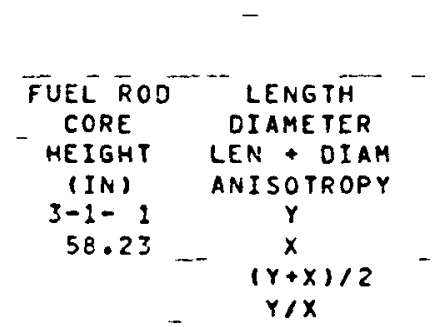

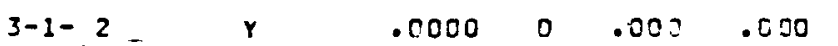

$60.37-\underset{3}{x}-\frac{x}{(y+x) / 2}$

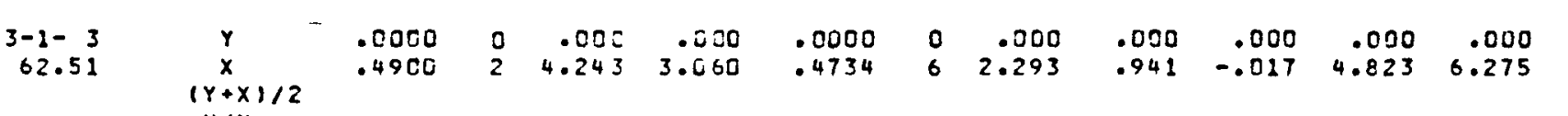

$$
\begin{aligned}
& \begin{array}{l}
y / X \\
(y+x / 2 \\
y / x
\end{array} \\
& x-1-4+2 x \\
& 64.65^{-}-\mathrm{X} \\
& (y+x) / 2 \\
& y / x \\
& \begin{array}{l}
3-1-5^{--} \\
66.79
\end{array} \\
& r \\
& \underset{(Y+X) / 2}{Y} \\
& 2.1500 \\
& Y / X
\end{aligned}
$$

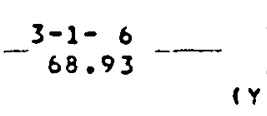

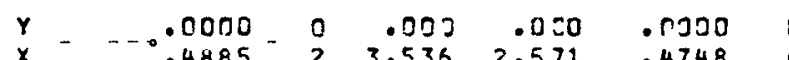

$$
\begin{aligned}
& (y+x) / 2 \\
& \begin{array}{l}
\text { FUEL - } \\
\text { STACK } \\
\text { AVERAGE - } Y \text { Y }
\end{array} \\
& .0000 \quad 0
\end{aligned}
$$

\begin{tabular}{|c|c|c|c|c|}
\hline & STRAI & & & \\
\hline$x$ & z & $x$ & 2 & $x$ \\
\hline EY & RY & SY & EPY & or \\
\hline EX & $R X$ & $5 x$ & EPX & $D X$ \\
\hline EV & RV & SV & EPY & DV \\
\hline $\begin{array}{l}\text { EW } \\
.060 \\
.040\end{array}$ & $\begin{array}{l}R H \\
.000 \\
.121\end{array}$ & $\begin{array}{l}S W \\
.050 \\
.735\end{array}$ & $\begin{array}{l}\text { EPH } \\
.000 \\
.518\end{array}$ & $\begin{array}{c}D W \\
.000 \\
1.014\end{array}$ \\
\hline .040 & .121 & .730 & .518 & 1.014 \\
\hline .0 & .0 & .0 & .0 & .0 \\
\hline $\begin{array}{l}.000 \\
.040\end{array}$ & $\begin{array}{l}.0<0 \\
.121\end{array}$ & $\begin{array}{l}.000 \\
.594\end{array}$ & $\begin{array}{l}.060 \\
.423\end{array}$ & $\begin{array}{l}.000 \\
.829\end{array}$ \\
\hline .343 & .121 & .594 & .423 & .829 \\
\hline .0 & .0 &.$B$ & .0 & .0 \\
\hline $\begin{array}{l}.000 \\
.040\end{array}$ & $\begin{array}{l}.000 \\
.120\end{array}$ & $\begin{array}{l}.000 \\
.959\end{array}$ & $\begin{array}{l}.000 \\
.633\end{array}$ & $\begin{array}{r}.000 \\
1.241\end{array}$ \\
\hline .040 & .120 & .959 & .633 & 1.241 \\
\hline .0 & .0 & .0 & .3 & .0 \\
\hline $\begin{array}{l}.000 \\
.040\end{array}$ & $\begin{array}{l}.000 \\
.121\end{array}$ & $\begin{array}{r}.000 \\
.754\end{array}$ & .000 & $\begin{array}{r}.000 \\
+028\end{array}$ \\
\hline .040 & .121 & .754 & .524 & 1.028 \\
\hline .0 & .0 & .0 & .0 & .0 \\
\hline .009 & .306 & .123 & .123 & .241 \\
\hline .040 & .120 & .713 & .510 & 1.000 \\
\hline .025 & .060 & .362 & .262 & .514 \\
\hline 2.4 & 3.3 & 19.9 & 14.4 & 28.3 \\
\hline פסת. & .000 & .000 & .000 & 000. \\
\hline .040 & .121 & .714 & .515 & 2.008 \\
\hline .040 & .121 & .714 & .515 & 1.008 \\
\hline .0 & .0 & .0 & .0 & .3 \\
\hline .009 & .006 & .123 & .123 & .241 \\
\hline .040 & .122 & .628 & .208 & .438 \\
\hline .025 & .060 & .320 & .121 & .237 \\
\hline 1.7 & 4.2 & 22.4 & 8.3 & 16.3 \\
\hline
\end{tabular}

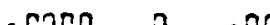

$$
\begin{aligned}
& .4734 \\
& \begin{array}{r}
.000 \\
6 \quad 1.318
\end{array} \\
& .000
\end{aligned}
$$

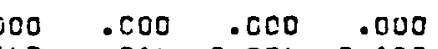

$$
\begin{aligned}
& . \quad .014 \quad 3.774 \quad 5.153 \\
& \begin{array}{rrr}
1.900 & 1.903 & 2.0772 \\
3.536 & 2.571 & .4733
\end{array} \\
& \begin{array}{lr}
1 & 1.900 \\
6 & .765
\end{array} \\
& 1.903 \\
& \begin{array}{l}
-.07 \\
-.017
\end{array} \\
& \begin{array}{ll}
2.687 & 5.274 \\
3.618 & 5.081
\end{array} \\
& 1 \\
& x \\
& \begin{array}{rrrr}
2.1500 & 1 & 1.900 & 1.953 \\
.4888 & 12 & 2.855 & 1.020
\end{array} \\
& Y / X
\end{aligned}
$$$$
-3.513
$$$$
-3.450
$$

0.000 -2.000
-2.798
-2.798 -2.798
.00

.386
$-3.247$ 


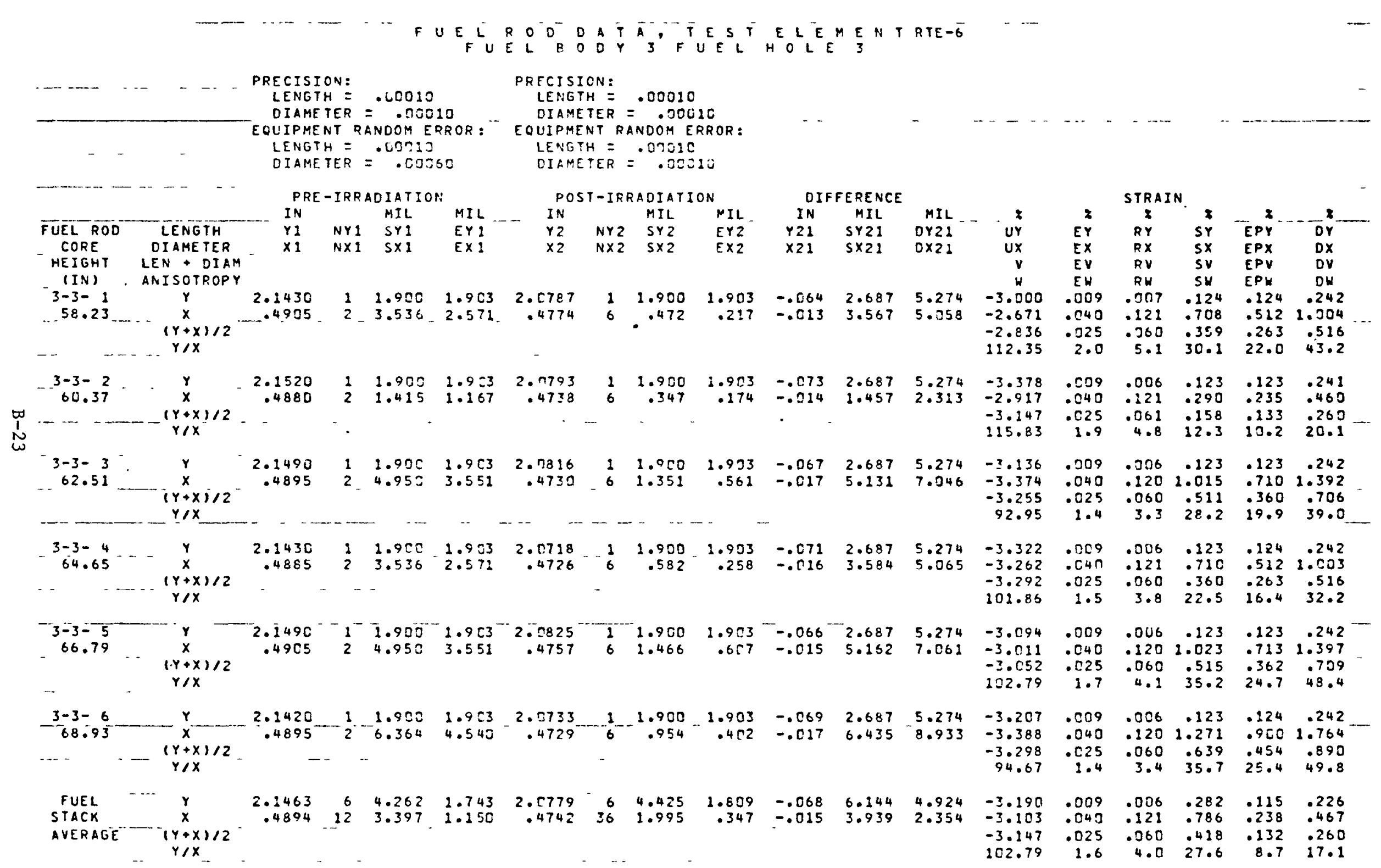


FUEL R O D D A T A, TE S T ELE MEN T RTE-6

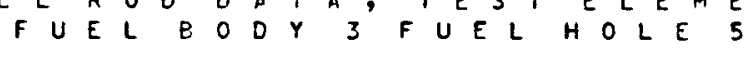

FUEL BODY J FUEL HOLE 5

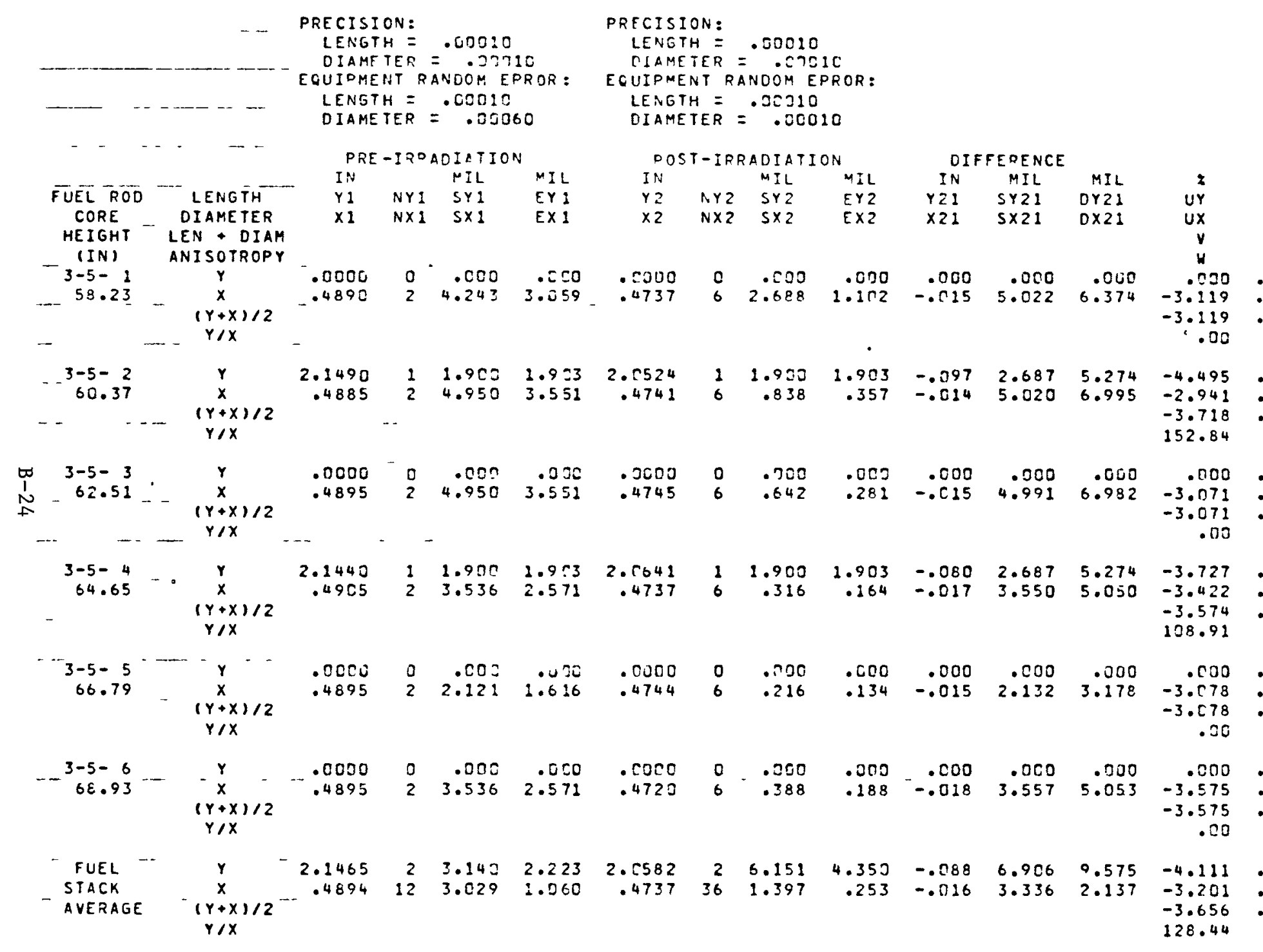




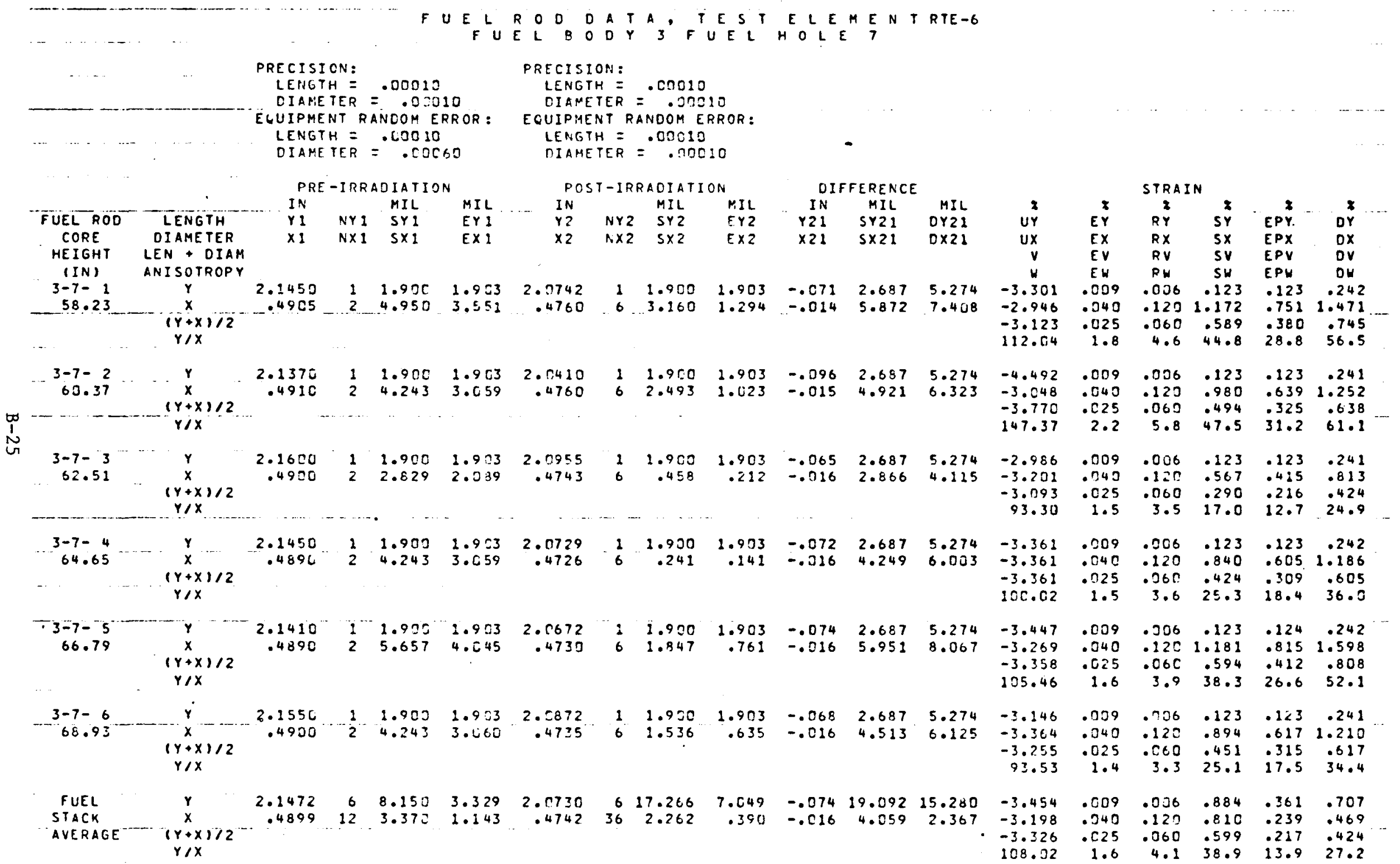


PRECISION:

LENGTH $=.000: 0$

DIAMETER = .0.010

EQUIPMENT RANCOM ERROR

LENGTH $=.00017$

DIAMETEP $=.00360$

$\cdots$

PRE - IRRADIATION

7

- FUEL ROD LENGTH

CORE DIAMETER

IN MIL MIL

YI NYI SYI EYI

HEIGHT LEN T DIAM
(IN) ANISOTROPY

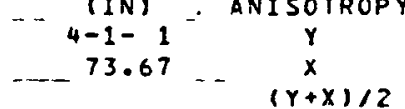

$(Y+X) / 2$
$Y / X$

$4-1-2$
75.49

$-$ $\ldots-(y+x)$

$\underset{1}{1}$

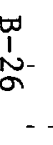

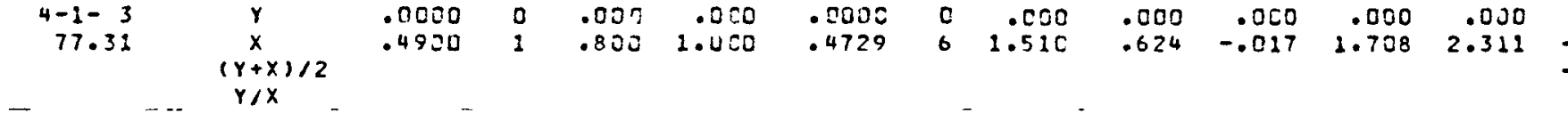

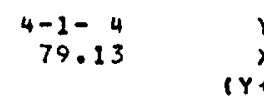

$$
\begin{aligned}
& \begin{array}{llll}
\lambda & .0000 \quad 0.000 & .0000
\end{array} \\
& (y+x) / 2 \\
& \begin{array}{r}
4-1-55^{-\cdots} \\
80.94
\end{array} \\
& Y / X \\
& 80.94-\underset{(Y+X)}{X} \\
& \begin{array}{l}
(y+X) / 2 \\
y / X
\end{array} \\
& \begin{array}{rr}
4-1-6 \\
82.76
\end{array}-\begin{array}{c}
Y \\
X \\
(Y+X) \\
Y, X
\end{array} \\
& \begin{array}{l}
(Y+X) / 2 \\
Y / X
\end{array} \\
& \begin{array}{llll}
.2020^{-} & 0 & .005 & .000 \\
.4900^{2} & 1 & .800 & 1.000
\end{array} \\
& \because 4739
\end{aligned}
$$$$
\text { TER = - DOOOIO }
$$$$
\text { LENCTH }=.30010
$$$$
\text { OIAMETER }=.00010
$$

POST-IRRADIATION

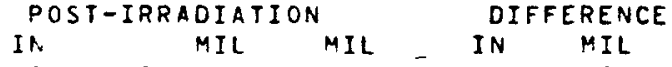

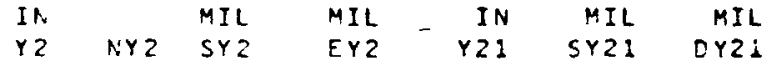$$
X 2 N X 2 \text { SX2 EX2 XII SY21 DYZL }
$$

$.0000 \quad 0.000 .000$

. กบ00

$.4728 \quad 6 \quad 1.704$

$\begin{array}{rrrr}.000 & .020 & .020 & .000 \\ .703 & -.016 & 1.083 & 2.397\end{array}$

397

.0000

$$
0.020
$$

.009

$.000 \quad .000 \quad .000$

$.0212-3.476$

.476
.476
.30

.000

-3.486
-3.486

.486
.00

.000
-3.510
-3.5
-50

0
0

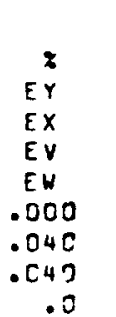

STRAIN

RY SY

$\begin{array}{ll}R X & S X \\ R V & S Y\end{array}$

$\begin{array}{ll}R W & \text { SW } \\ .000 .000\end{array}$

$\begin{array}{ll}.000 & .000 \\ .120 & .382\end{array}$

.0244

.0

$\begin{array}{rllll}.000 & .000 & .000 \quad .000\end{array}$

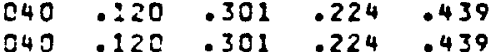

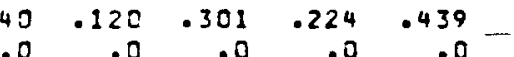

$.000 \quad .000 \quad .000 \quad .000 \quad .000$

$.040 \quad .120 \quad .346 \quad .235 \quad .460$

$.040 \quad .120 \quad .346 \quad .235 \quad .460$

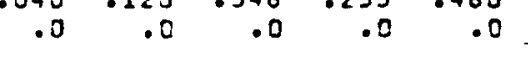

$.000 \quad .030 \quad .000 \quad .000 \quad .000$

$\begin{array}{lllll}.040 & .120 & .319 & .228 & .447\end{array}$

$\begin{array}{rrrrr}.040 & .120 & .319 & .228 & .447 \\ .0 & .0 & .0 & .0 & .0\end{array}$

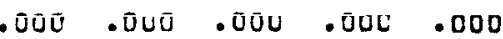

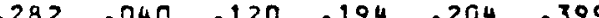

$\begin{array}{rrrrrr}-3.292 & .04 C & .120 & .194 & .204 & .399 \\ .00 & .0 & .0 & .0 & .0 & .0\end{array}$

.000

$-3.544$

.030 .000 .000 .000 .000

$\begin{array}{lllll}.030 & .700 & .000 & .000 & .000 \\ .040 & .120 & .257 & .215 & .421\end{array}$

.044

.040

$\begin{array}{rrrr}.120 & .257 & .215 & .421 \\ .0 & .0 & .0 & .0\end{array}$

.000
-3.228

$.000 \quad .000 \quad .000 \quad .000 \quad .003$

$-3.228$

.040

$.120-.235 \quad .211 \quad .423$

.00

.040

$.120 \quad .235 \quad .211 \quad .413$

.000 -3.406
-3.406

$.000 \quad .000 .000 \quad 0000 \quad .000$ $\begin{array}{lllll}.040 & .120 & .305 & .140 & .274\end{array}$

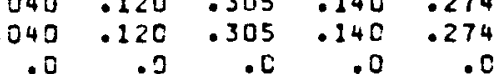




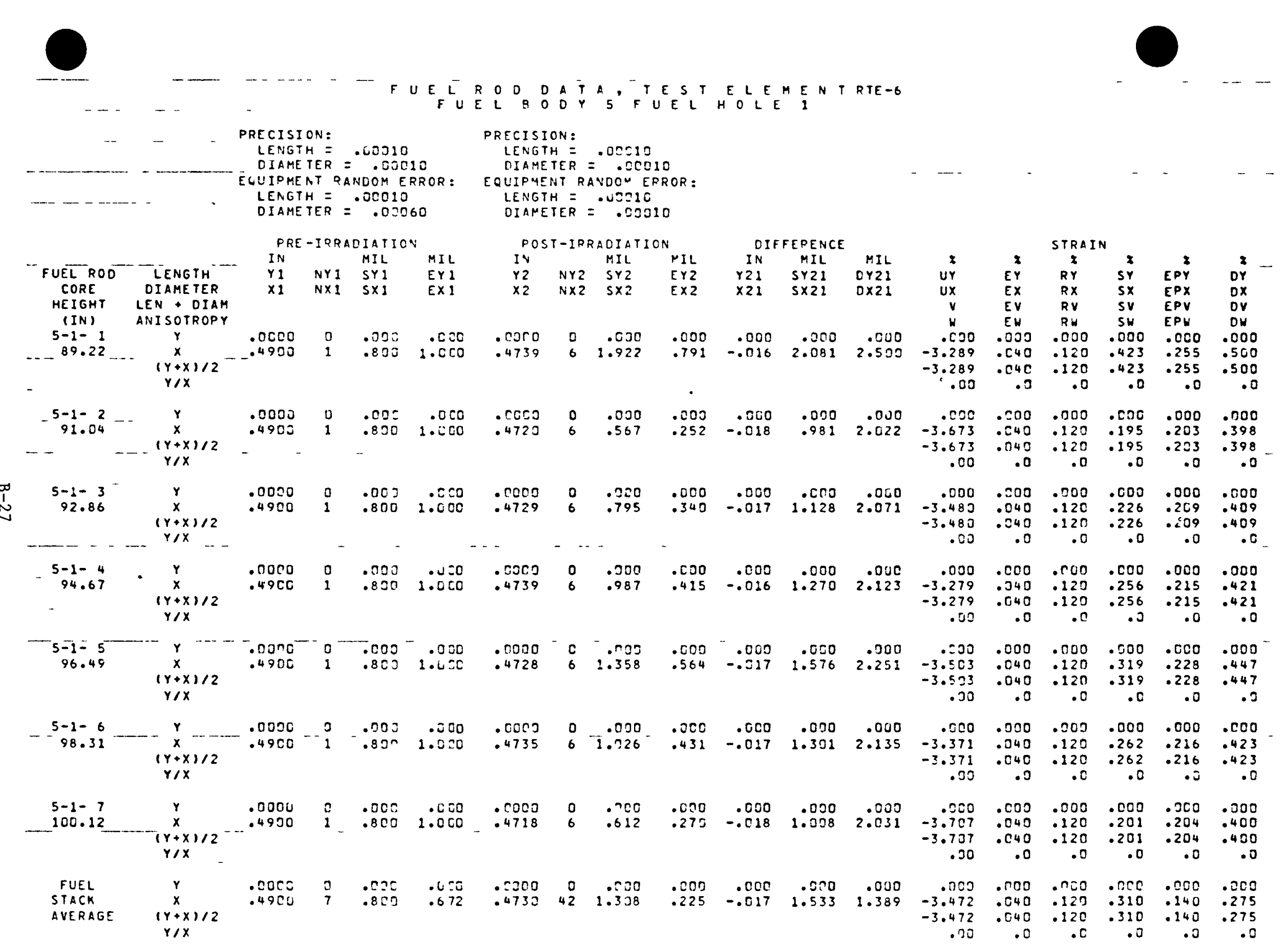




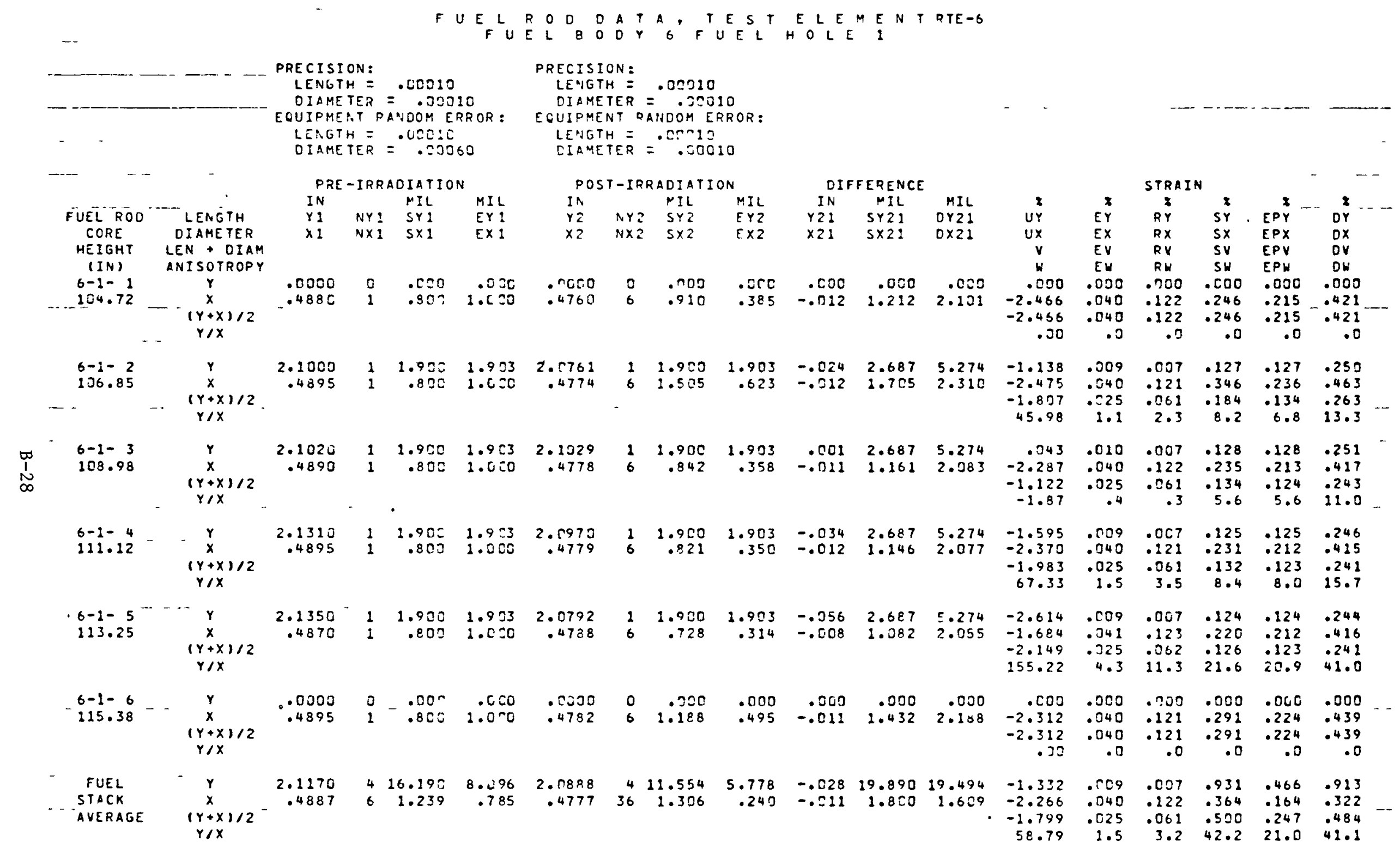




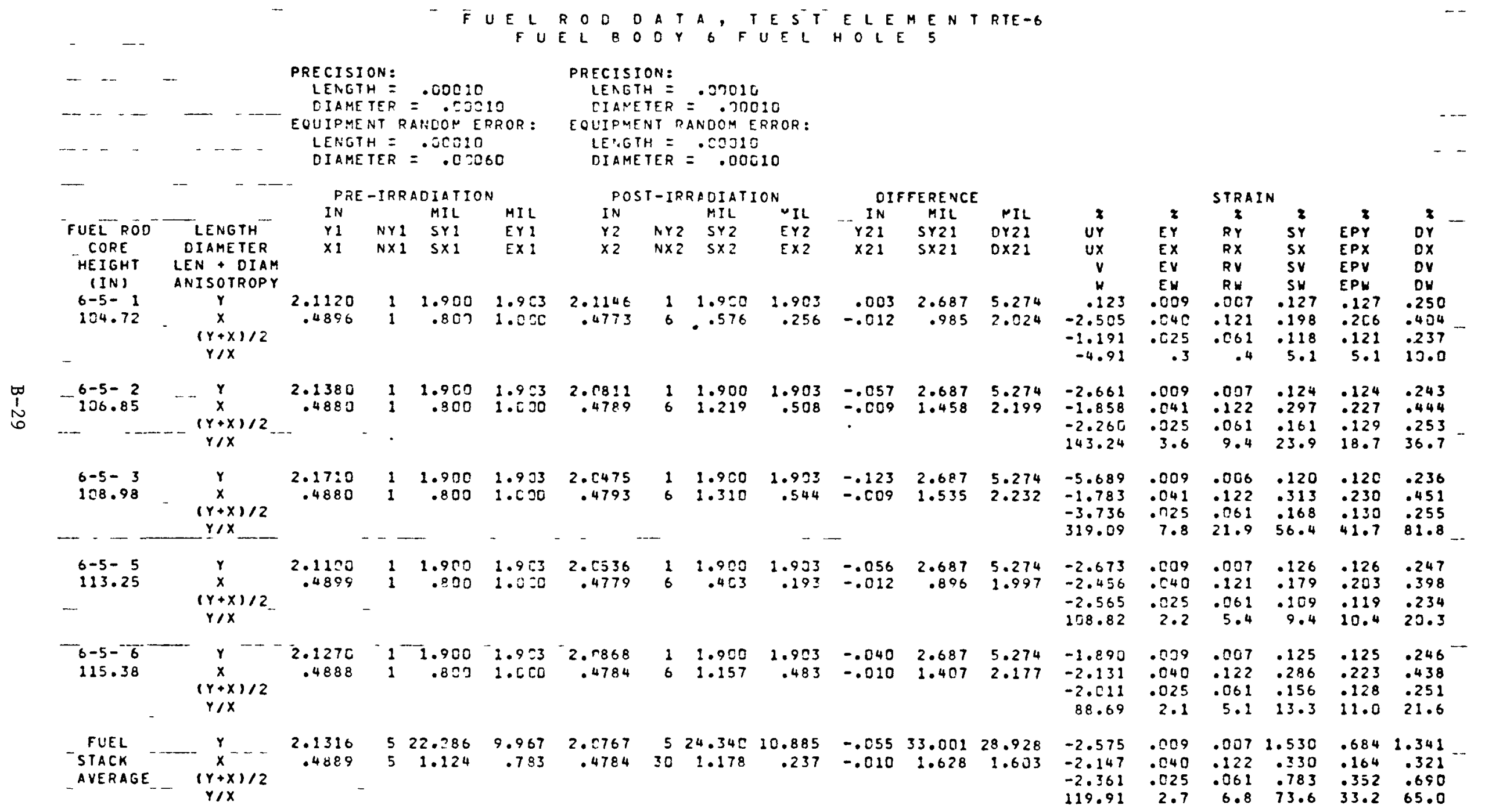


FUEL RODO OATA, TESTELEMENTRTE-6

FUEL E O D Y G FUEL HOLE?

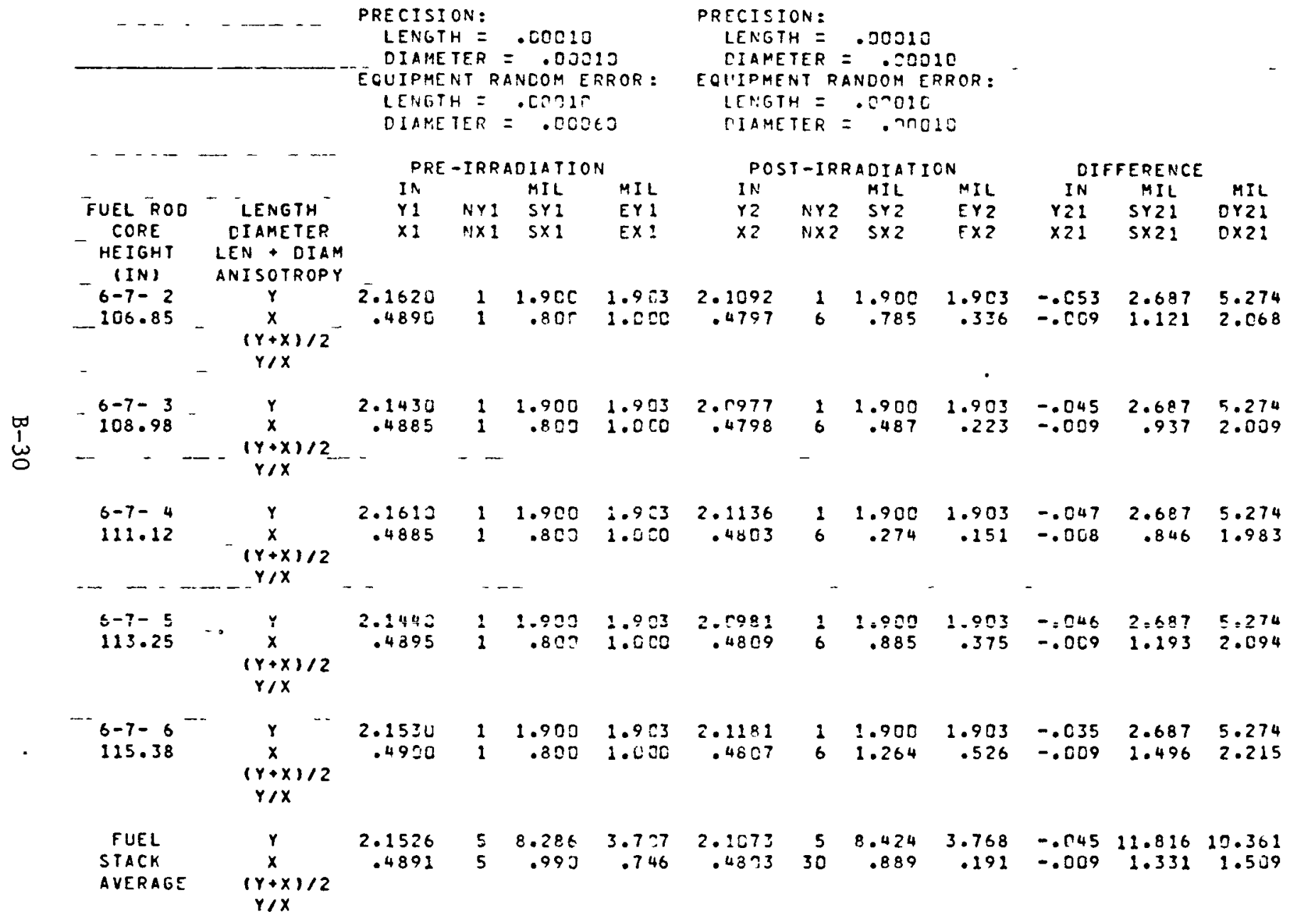$$
\text { y }
$$ 


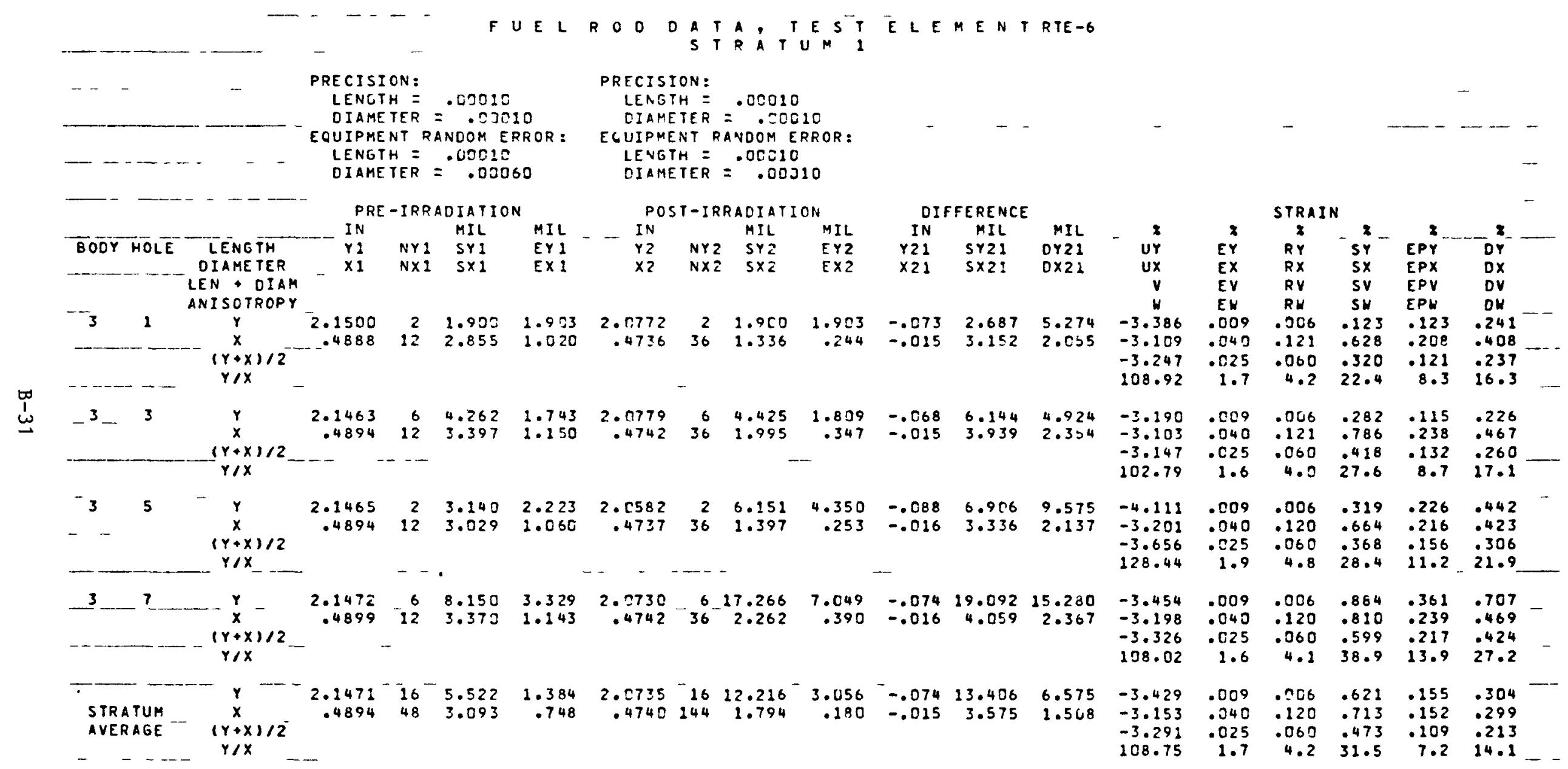




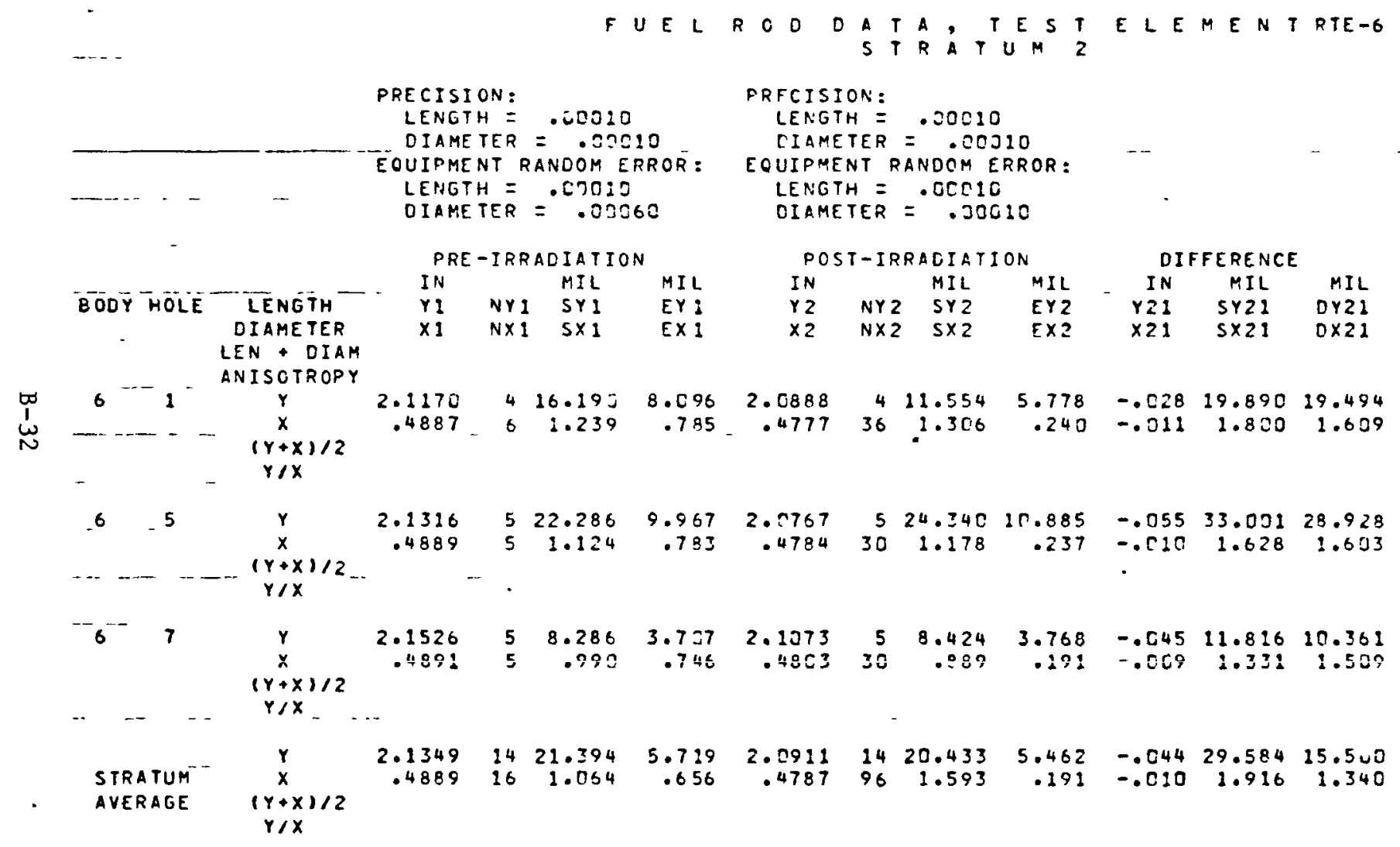

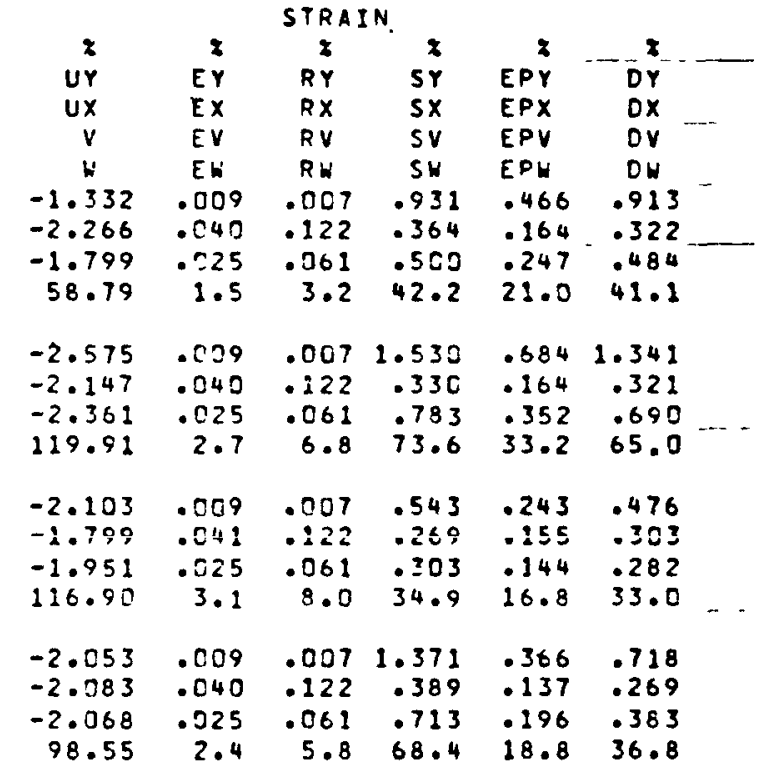




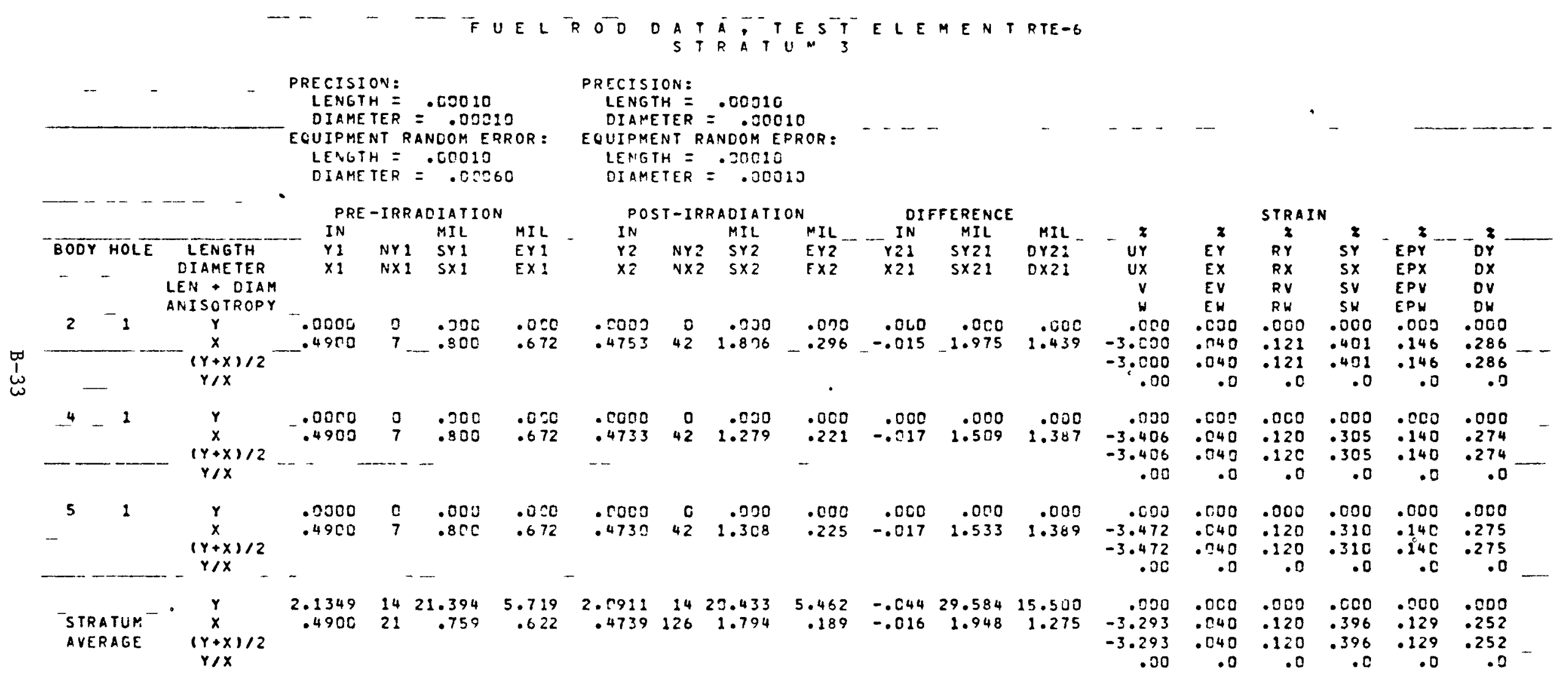




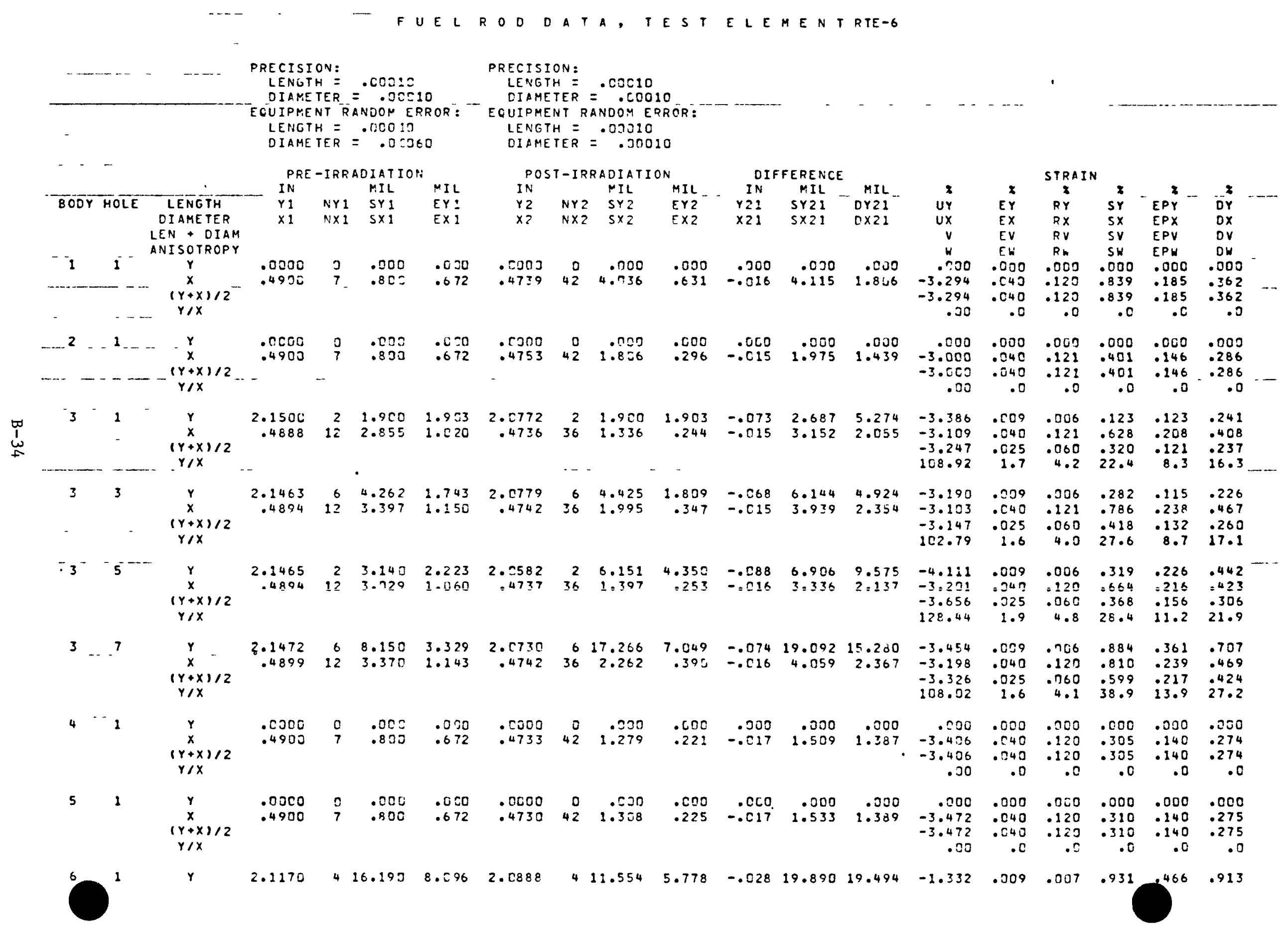




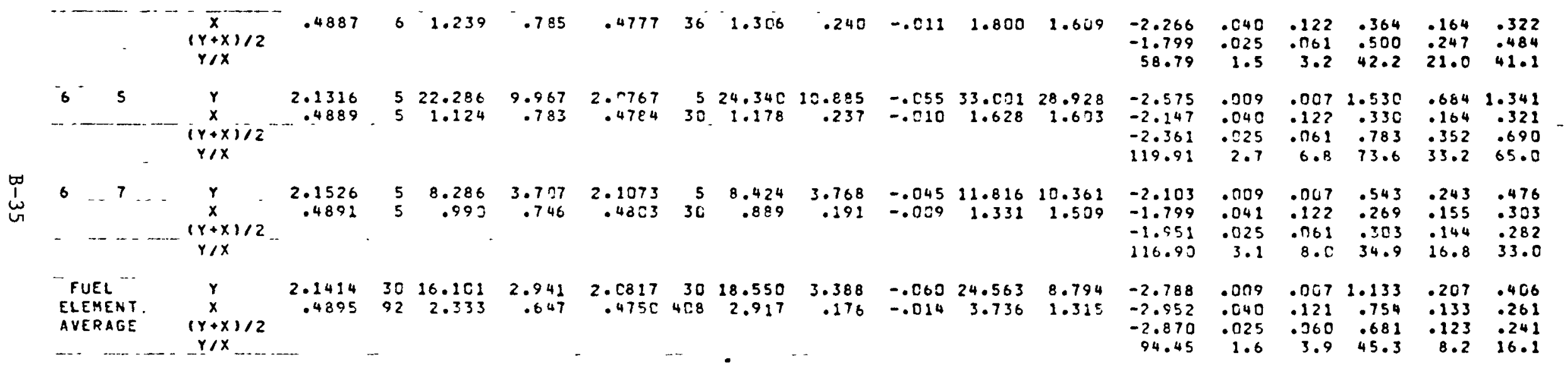


FUEL RDD aVERAGE SAMPLE STANDARO DEVIATIONS

FUEL BODY FUEL HOLE PRE-IRRAD, LENGTH POST-IRRAD, LENGTH PRE-IRRAD, DIAMETER POST-IRKAD, DIAMETER

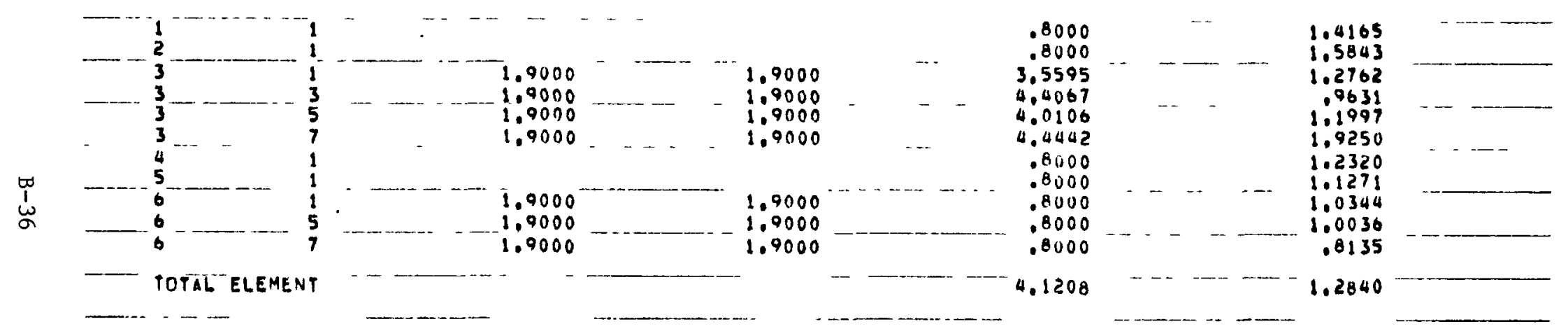

ALL STANDARD UEVIATIONS ARE GIVEN IN MILS

THEAVERAGE SAMPLE RANOOM ERRUR FOR EACH FUEL STACK IS LISTED. HOWEVER, WHEN CALCULATING PHE AVERAGE SAMPLE RANDUM ERROR FOR THE ENTIRF ELFMENT. ONLY NON.DEFAULT FUEL STACK AUERAGE gAMPLE RANDOM ERRORg IRE INCLUDED 
FUEL BODY

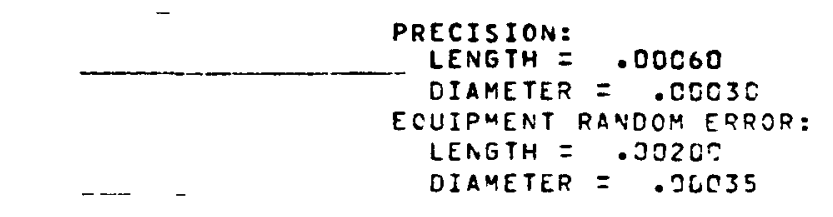

PRECISION:

.00062

DIAMETER $=.0 n C 30$

COUIPMFNT RANDOM ERROR:

LENGTH $=.3020$ S LENGTH $=.03200$

- PRE-IRRADIATION POST-IRRADIATION

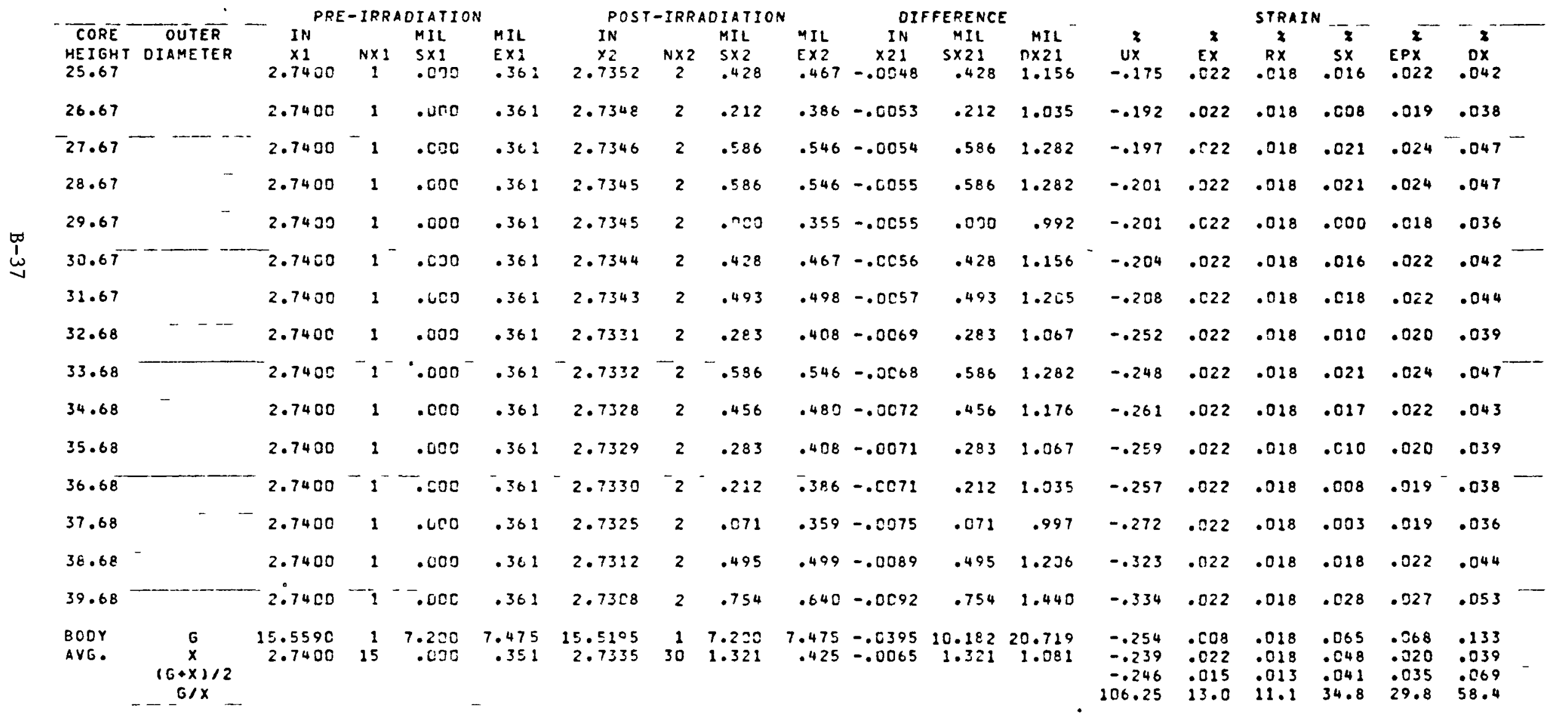


FUEL B O D Y D A T A A T E S T T E L E MENT RTE-6

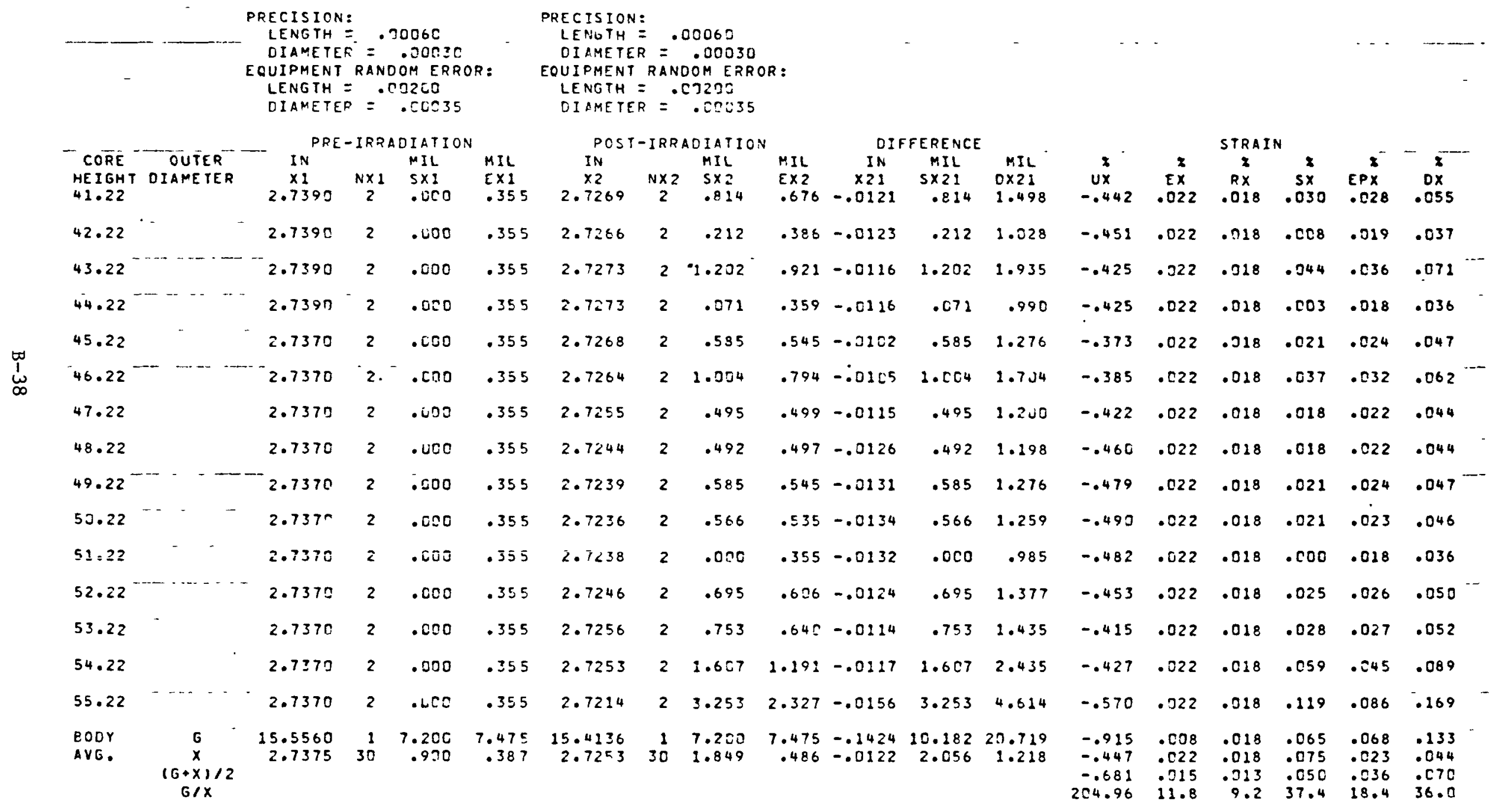




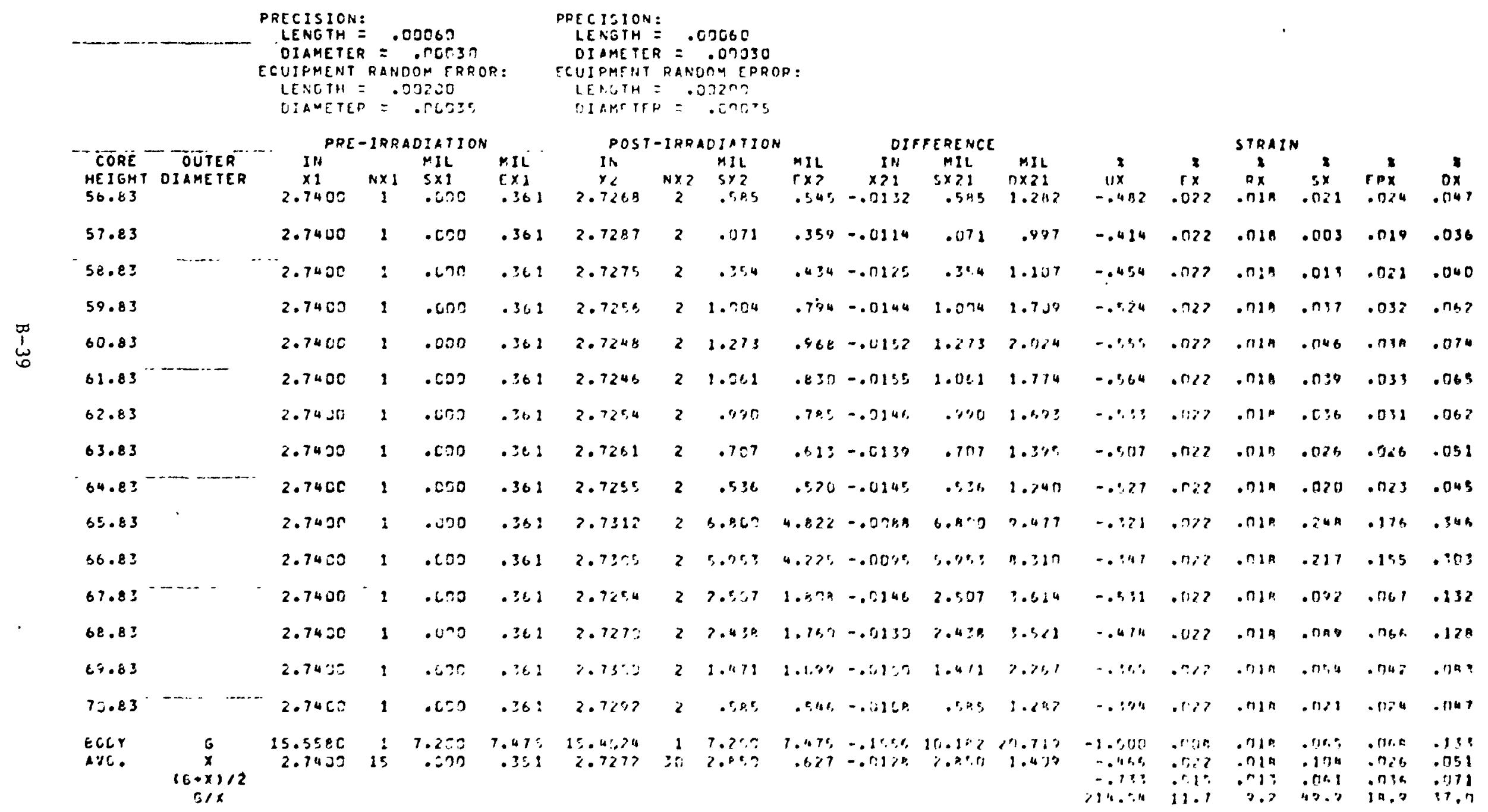




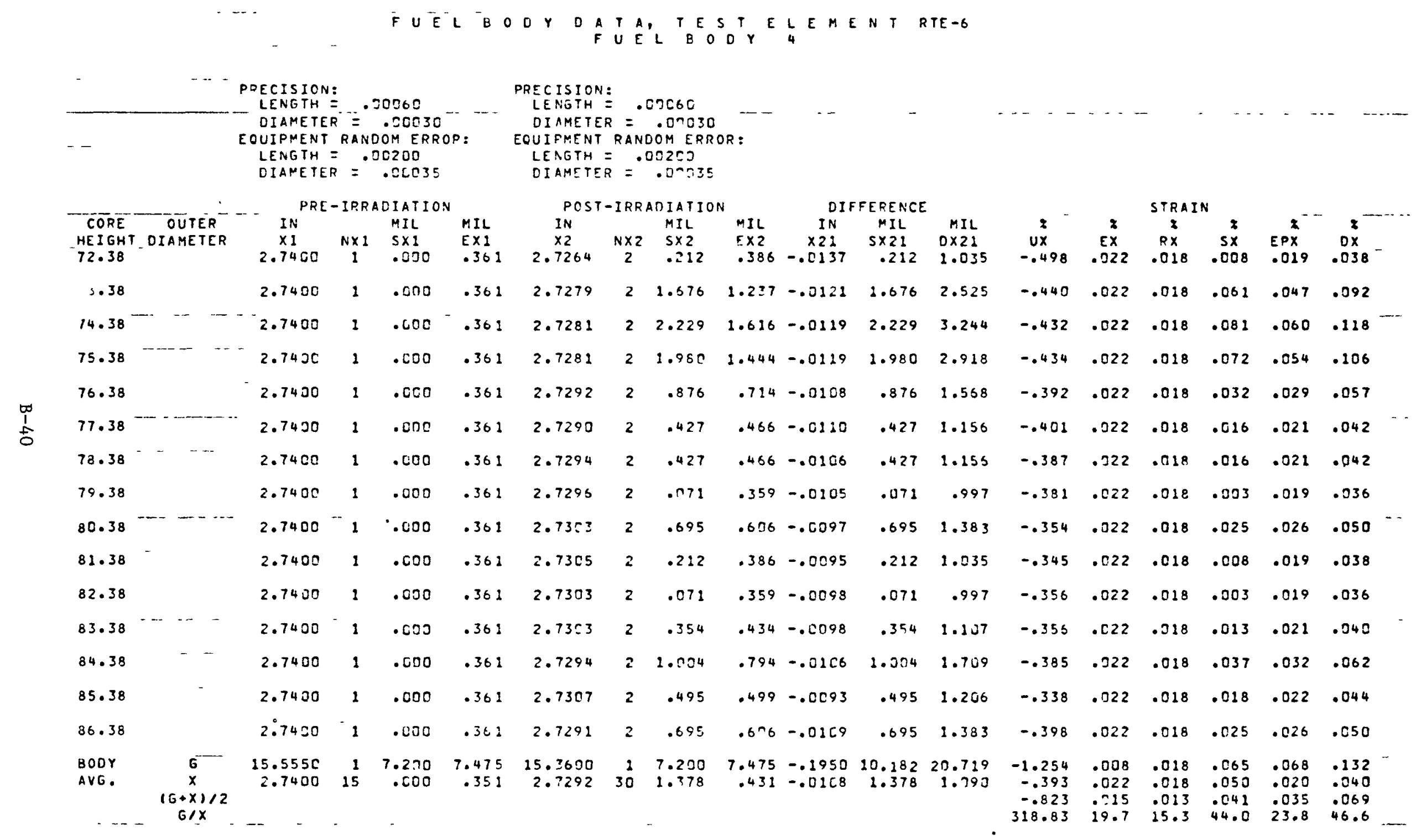




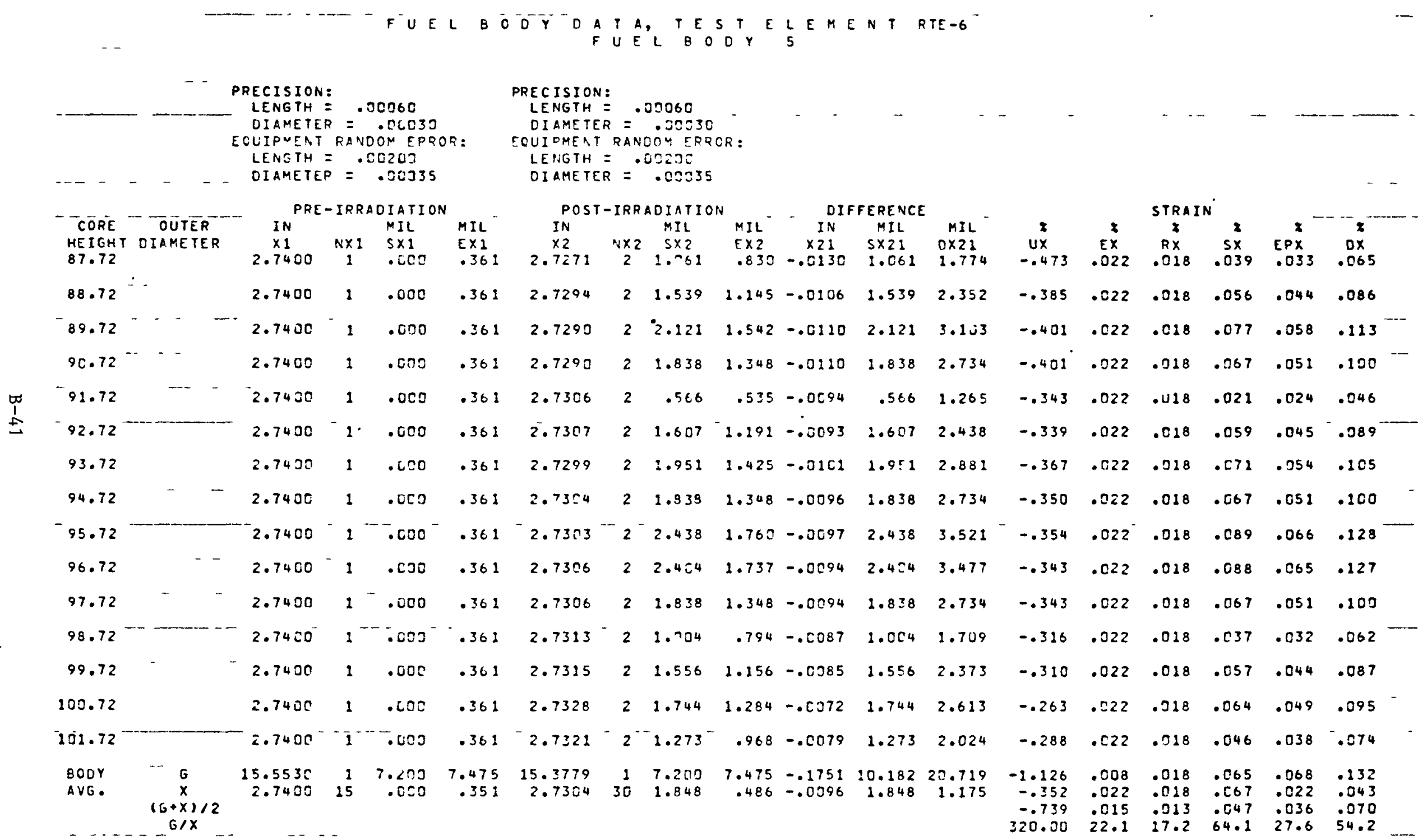


FUEL B O O Y O A T A, TEST ELEMENT RTE-6

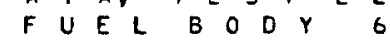

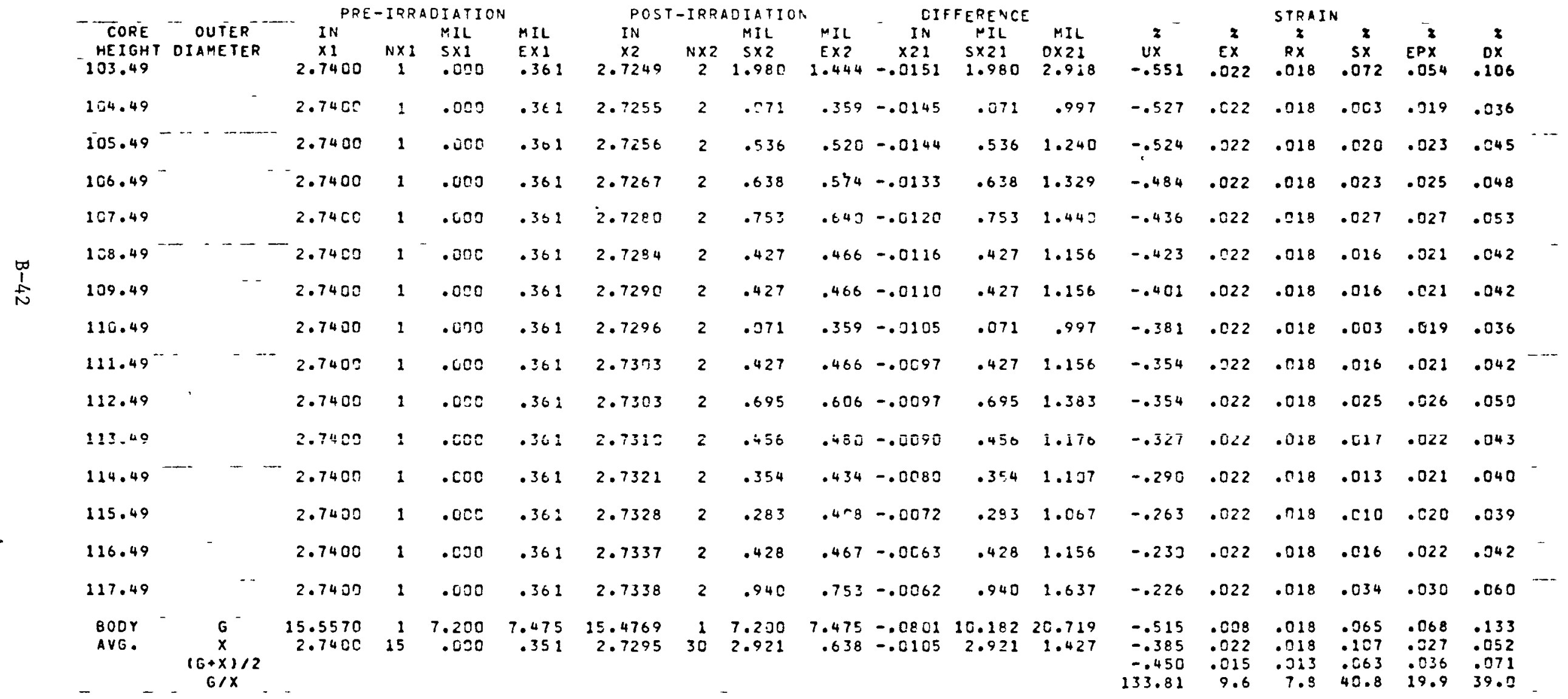


FUEL BODY AVERAGE SAMPLE STANDARD DEVIATIONS (MILS)

FUEL AUDY - PREFIRRAD: OIAMETER POSTOIRRAD. DIAMETER

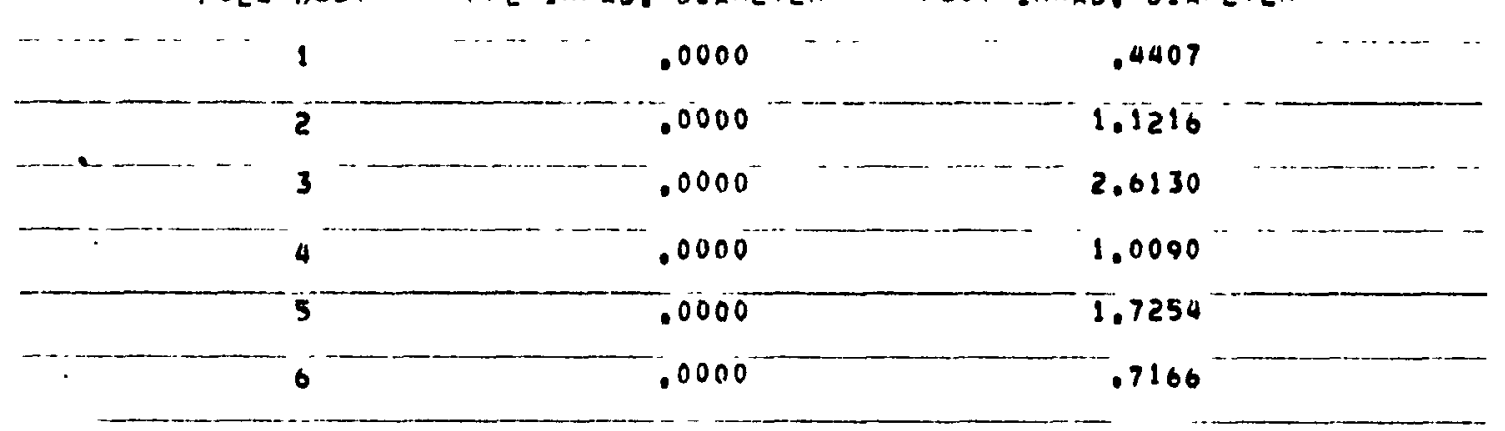




\begin{tabular}{|c|c|c|c|c|}
\hline & & $\begin{array}{l}\text { PRECISION: } \\
\text { LENGTH = } \\
\text { DIANETER }\end{array}$ & $=.00060$ & $\begin{array}{l}\text { PRECISION: } \\
\text { LENGTH = .0OOSO } \\
\text { CILMETER }=.00030\end{array}$ \\
\hline - - . & - & $\begin{array}{l}\text { EQUIPMENT R } \\
\text { LENGTH }= \\
\text { DIAMETER }\end{array}$ & $\begin{array}{l}\text { RANDOM ERROR: } \\
\text {.OO2OS } \\
=\quad .00 C 35\end{array}$ & $\begin{array}{l}\text { EQUIPMENT RANDOH ERROR: } \\
\text { LENGTH }=.002 C 0 \\
\text { OIAMETER }=.09035\end{array}$ \\
\hline
\end{tabular}

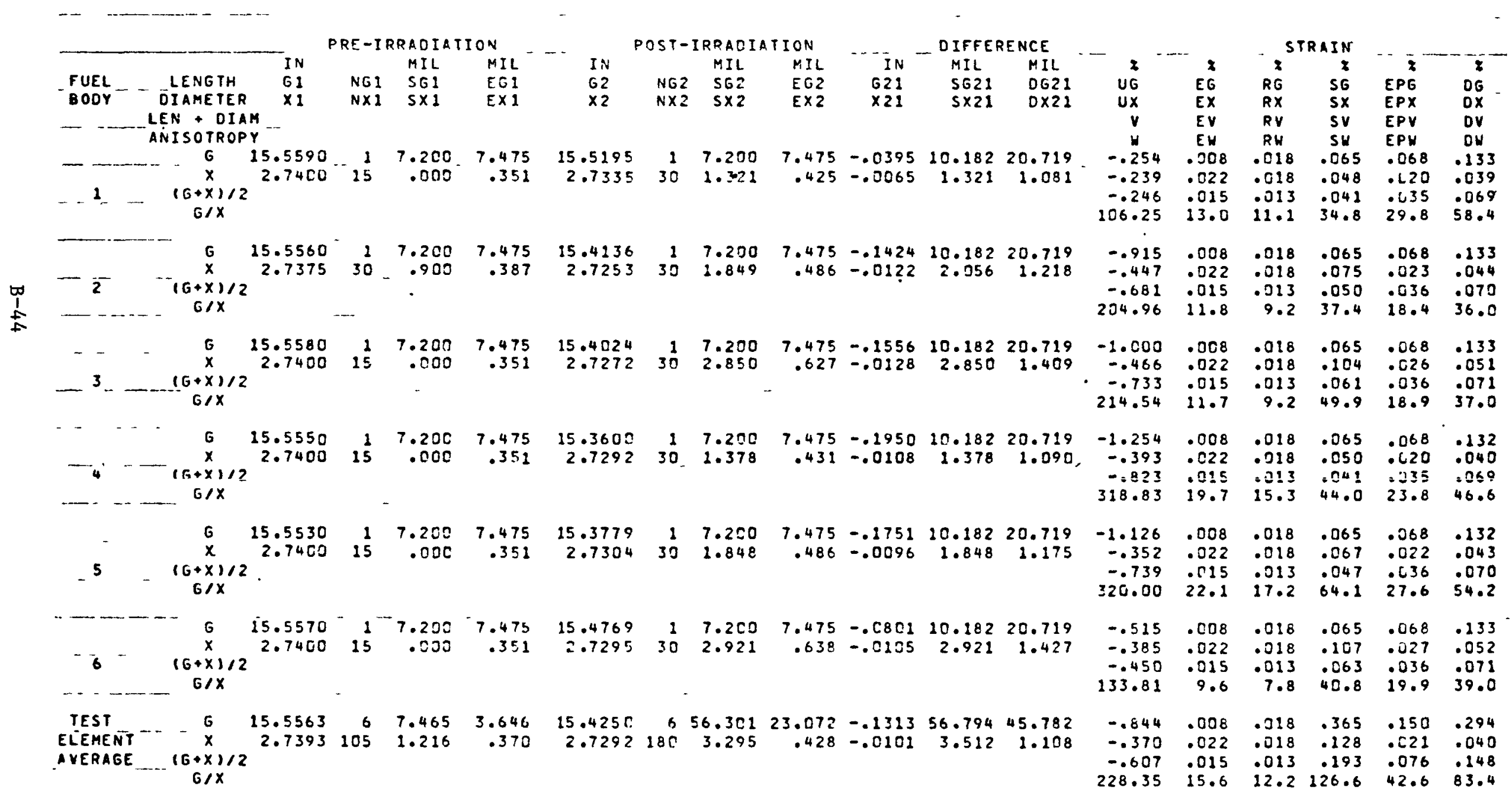


-

SLEEVE DATA T E SE D ON O. D. MEASUREMENTSI

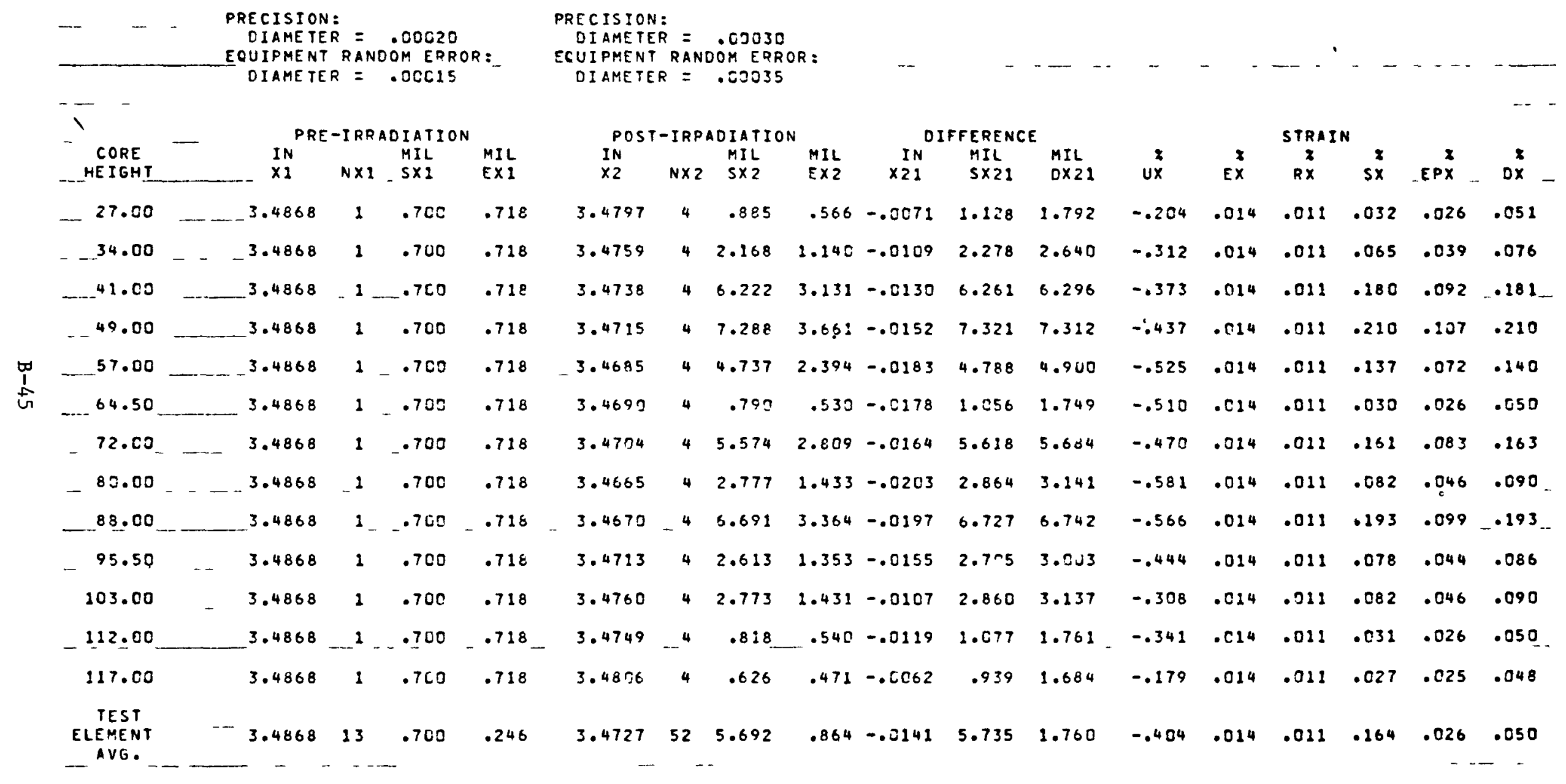




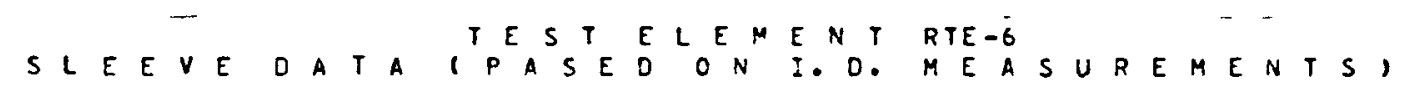

PRECISION:

DIAMETER $=. D 002 C$

PRECISICN:

DIAMETER = . SOE 00

EOUIPMENT RANDOM ERROR: EOUIPMENT RANDOM ERROR:

DIAMETER = . OCO15 DIAMETER = .00235

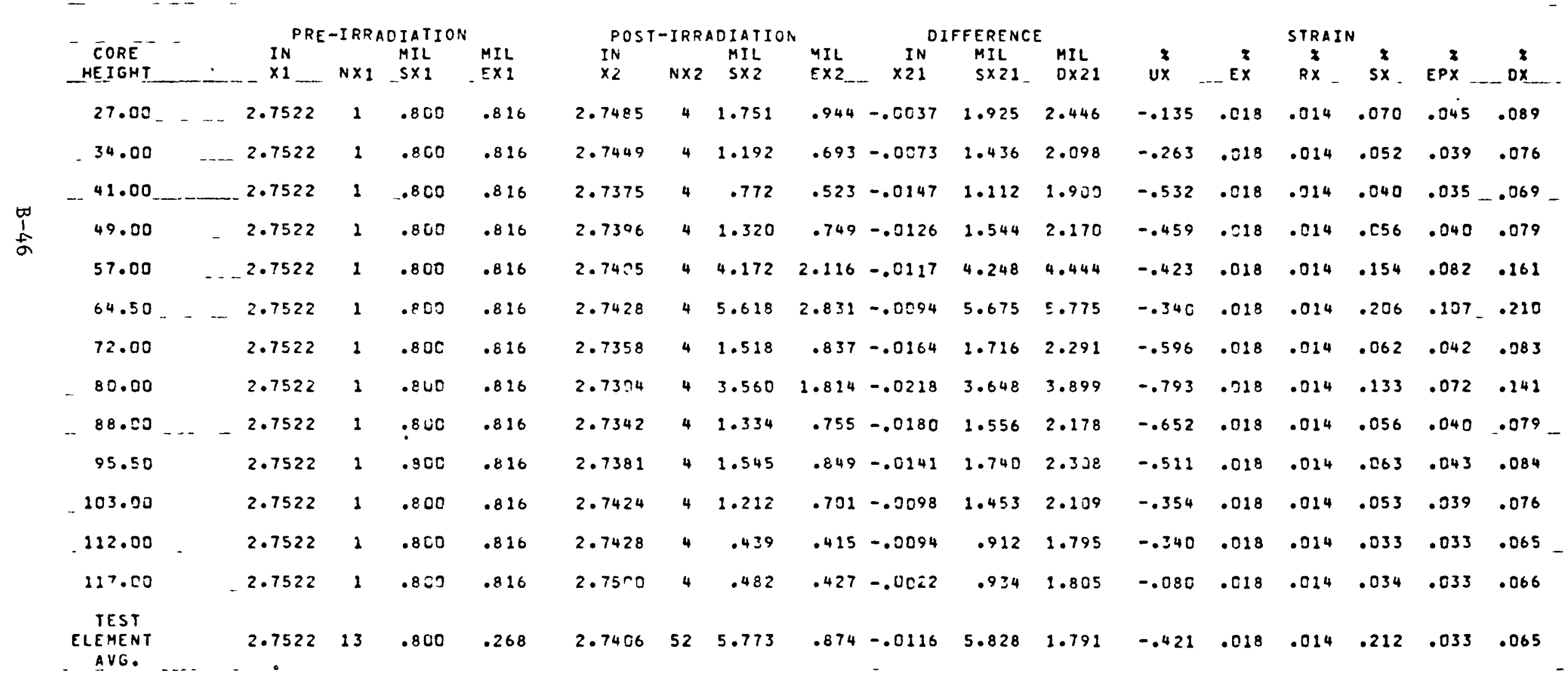


FUEL STACK DAT

TUEL STACK LENCTH

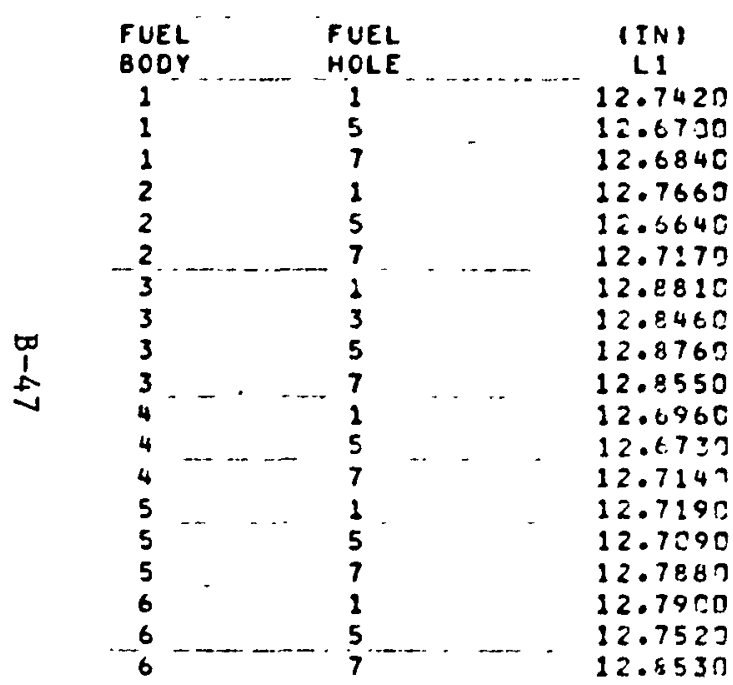

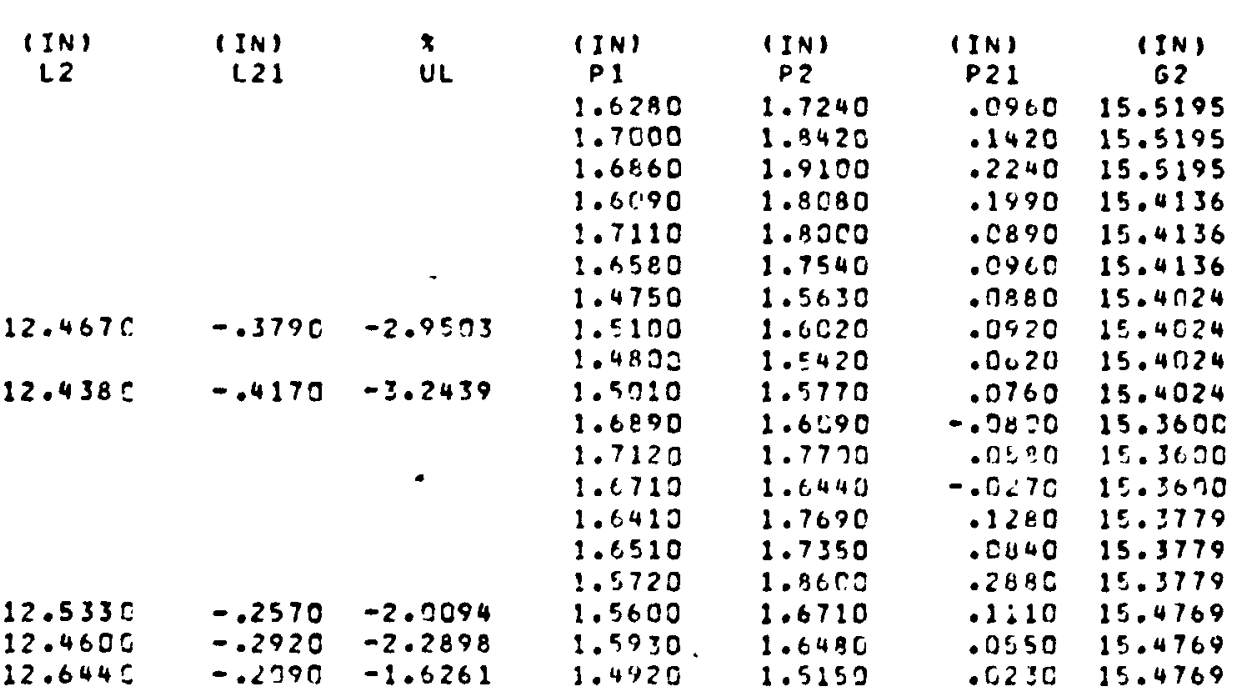

INOIRECT FUEL STACK LENGTH

\begin{tabular}{|c|c|c|}
\hline $\begin{array}{c}\text { (IN) } \\
62 \text { ! }\end{array}$ & $\begin{array}{l}\text { IIN } \\
\text { LI }\end{array}$ & ULI I \\
\hline $\begin{array}{l}14.3335 \\
14.3335 \\
14.3335\end{array}$ & $\begin{array}{l}12.6095 \\
12.4915 \\
12.4235\end{array}$ & $\begin{array}{l}-1.0397 \\
-1.0087 \\
-2.0536\end{array}$ \\
\hline 14.2434 & 12.4354 & -2.5896 \\
\hline 14.2434 & 12.4434 & -1.7419 \\
\hline 14.2434 & .4894 & -1.7896 \\
\hline 14.2124 & 12.6494 & -1.7978 \\
\hline 14.2124 & 12.6104 & -2.8339 \\
\hline 14.2124 & 12.6704 & .5866 \\
\hline 14.2124 & 12.6354 & .7082 \\
\hline 14.2047 & .5957 & .7003 \\
\hline 14.2547 & 4347 & 8206 \\
\hline 14.2247 & 12.5607 & -1.2060 \\
\hline 14.1983 & 12.4243 & -2.2775 \\
\hline 14.1983 & 12.4633 & -2.9530 \\
\hline 14.1403 & 12.2383 & -3.5163 \\
\hline $4 .<762$ & 12.6051 & -1.4455 \\
\hline 14.2711 & 12.6231 & -1.3109 \\
\hline 1.2711 & 12.7561 & -.7536 \\
\hline
\end{tabular}


FUEL STACK DATA IESTELEMENT RTE-6 FUEL STACK LEAGTH

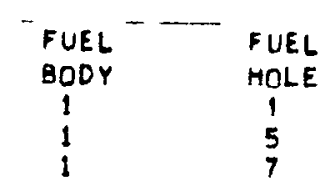

STRATUM L,P, G,U (IN OR X) AVG E (IN UR $X)$

STRATUY $S$ (IN OR $x$ ) 1 EP (IN UR $X)$
D (IN UR $X)$

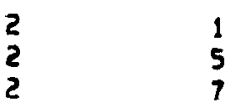

1
5

$\underset{1}{\infty}$

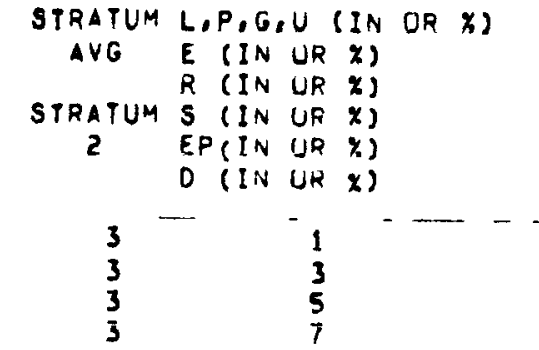

STRATUM L,P,G,U (IN OR X)

AVG E (IN UR $x$ )

STRATUM 'S (IN UR $X$ )

3 EP(IN UP $X)$

D (IN UR $X)$

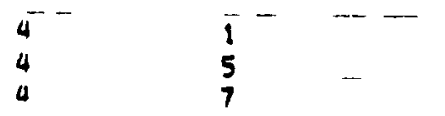

(

12.6987

$.006 \mathrm{C}$

.0070

.0382

.0232
.0454

\subsection{0}

12.6640

12.7170

12.7157
.0060

$$
.0511
$$

.05112

.0594

$12.8410^{-}$

12.8460
12.8760

12.4550

12.8045

.0060

.0070

.0168

.0110
.0215

12.6060

12.6730
.0000

.0000

.0000

.11000

FUEL HOLE PLENUM LENGTH

$\begin{array}{lllc}(I N) & (I N) & (I N) & \text { (IN) } \\ 11 & P 2 & P 21 & 62 \\ 1.6280 & 1.7240 & .0900 & 15.5195 \\ 1.7000 & 1.8420 & .1420 & 15.5145 \\ 1.0860 & 1.9100 & .2240 & 15.5145 \\ & & & \\ 1.0713 & 1.8253 & .1540 & 15.5145 \\ .0003 & .0003 & .0006 & .0006 \\ .0003 & .0003 & .0045 & .0020 \\ .0382 & .0941 & .1016 & .0072 \\ .0220 & .0543 & .0586 & .0075 \\ .0432 & .1065 & .1149 & .0147\end{array}$

$1.6090 \quad 1.0080 \quad .1990 \quad 15.4136$

$1.7110 \quad 1.8000$

$1.6580 \quad 1.7540$

.0490

.0960

15.4136
15.4136

1.6593

.0003

1.7873

.0003

.0003

.1280

15.4936

$.0000 \quad .0000 \quad .0000$

.0000

.0000

.0000

.000

.0003

.0295

.0577

$\therefore .0750$

.0291

.0006

.0005
.0588

.0588
.0339

.0665

.0330

1.4750
1.5100

1.4800

1.3010

1.6020
1.5020

1.5420

.0880

.0920

.0620

.0760

1.4915
.0009

$.0000-0.0120-03.2026$

$.0020-.0066$
.0020

$\begin{array}{ll}.00205-.0073 & .0549 \\ .0205 & .0205\end{array}$

$.0146 \quad 0183$

$\begin{array}{lll}.0146 & .1183 & .1406 \\ .0287 & .1358 & .2755\end{array}$

.0003

.0167

1.5710

.0795

.0006

.0015

.0302

$\begin{array}{lll}.0084 & .0126 & .0151 \\ .0160 & .0247 & .0296\end{array}$

. .0800

1.7120

1.6710

1.6090
1.7700

1.7700

.0580

. .0270

15.3000

$13.300 n$
INDIRECT FUEL ST $\triangle C K$ LENGTH

\begin{tabular}{|c|c|c|}
\hline $\begin{array}{c}(I N) \\
621 \\
14.33355 \\
14.3335 \\
14.3335\end{array}$ & $\begin{array}{c}(I N) \\
1 I \\
12.6095 \\
12.4015 \\
12.4235\end{array}$ & $\begin{array}{c}x \\
U L 1 \\
-1,0397 \\
-1,0087 \\
-2,0536\end{array}$ \\
\hline $\begin{array}{r}14.3335 \\
.0006 \\
.0018 \\
.0060 \\
.0069 \\
.0135\end{array}$ & $\begin{array}{r}12.5082 \\
.0009 \\
.0019 \\
.0943 \\
.0548 \\
.1074\end{array}$ & $\begin{array}{r}-1.5000 \\
.0533 \\
.0563 \\
.7999 \\
.4673 \\
.9159\end{array}$ \\
\hline $\begin{array}{l}14.2434 \\
14.2434 \\
14.2434\end{array}$ & $\begin{array}{l}12.4354 \\
12.4434 \\
12.4894\end{array}$ & $\begin{array}{l}-2.5896 \\
-1.7419 \\
-1.7896\end{array}$ \\
\hline $\begin{array}{r}14.2434 \\
.0006 \\
.0018 \\
.0067 \\
.0009 \\
.0135\end{array}$ & $\begin{array}{r}12.4561 \\
.0009 \\
.0019 \\
.0299 \\
.0182 \\
.0357\end{array}$ & $\begin{array}{r}-2.0415 \\
.0529 \\
.0559 \\
.4583 \\
.2739 \\
.5369\end{array}$ \\
\hline $\begin{array}{l}14.2124 \\
14.2124 \\
14.2124 \\
14.2124\end{array}$ & $\begin{array}{l}12.6494 \\
12.6104 \\
12.6704 \\
12.0354\end{array}$ & $\begin{array}{l}-1.7978 \\
-1.8339 \\
-1.5906 \\
-1.7081\end{array}$ \\
\hline 14.2124 & 12,6414 & -1.7341 \\
\hline $\begin{array}{l}.0006 \\
.0018 \\
.0060 \\
.0069 \\
.0135\end{array}$ & $\begin{array}{l}.0009 \\
.0019 \\
.0260 \\
.0140 \\
.0281\end{array}$ & $\begin{array}{l}.0525 \\
.0554 \\
.2397 \\
.1396 \\
.2735\end{array}$ \\
\hline $\begin{array}{l}14.2047 \\
14.2047 \\
14.2047\end{array}$ & $\begin{array}{l}12,5957 \\
12,4347 \\
12,5607\end{array}$ & $\begin{array}{l}=.7903 \\
=1.8800 \\
=1.2000\end{array}$ \\
\hline
\end{tabular}




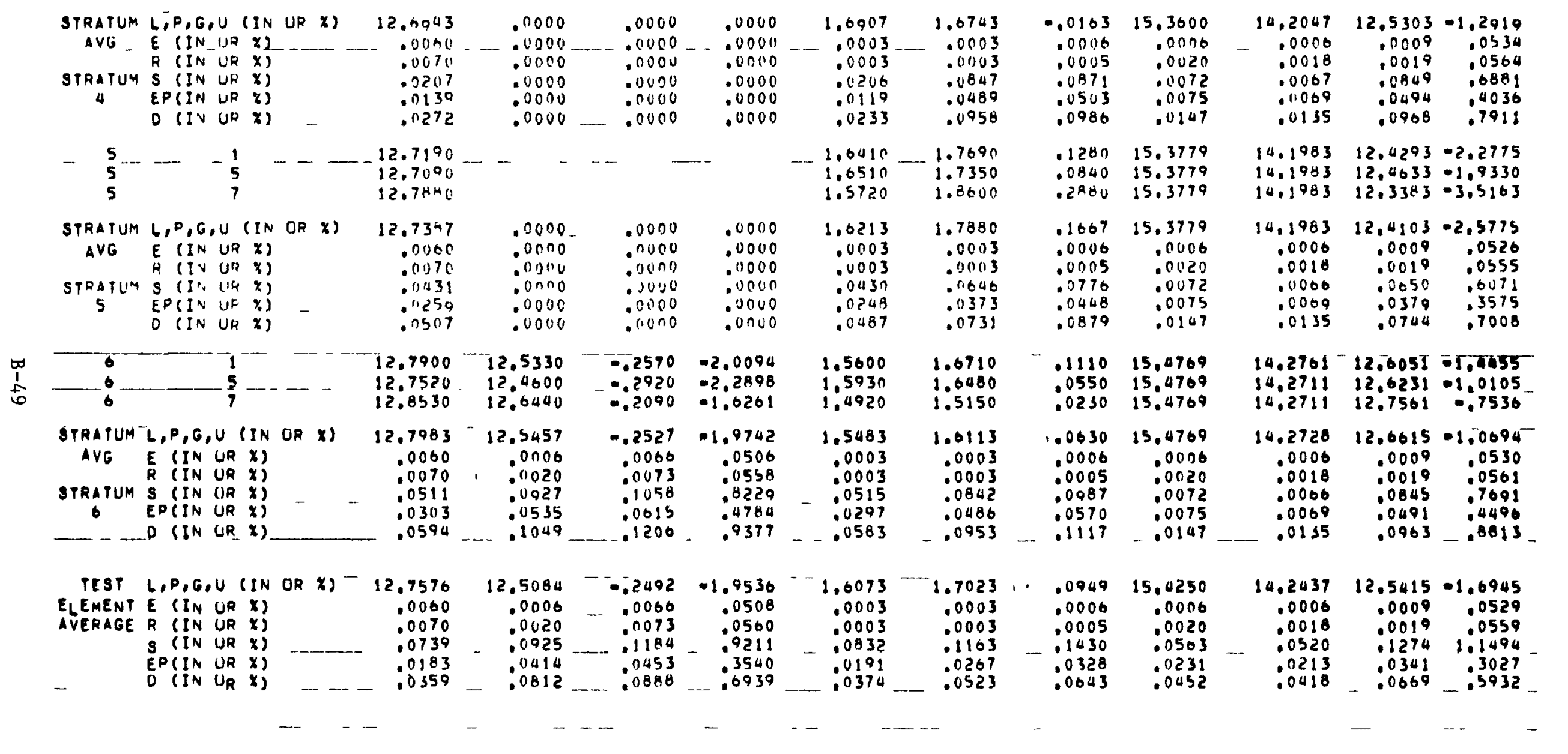




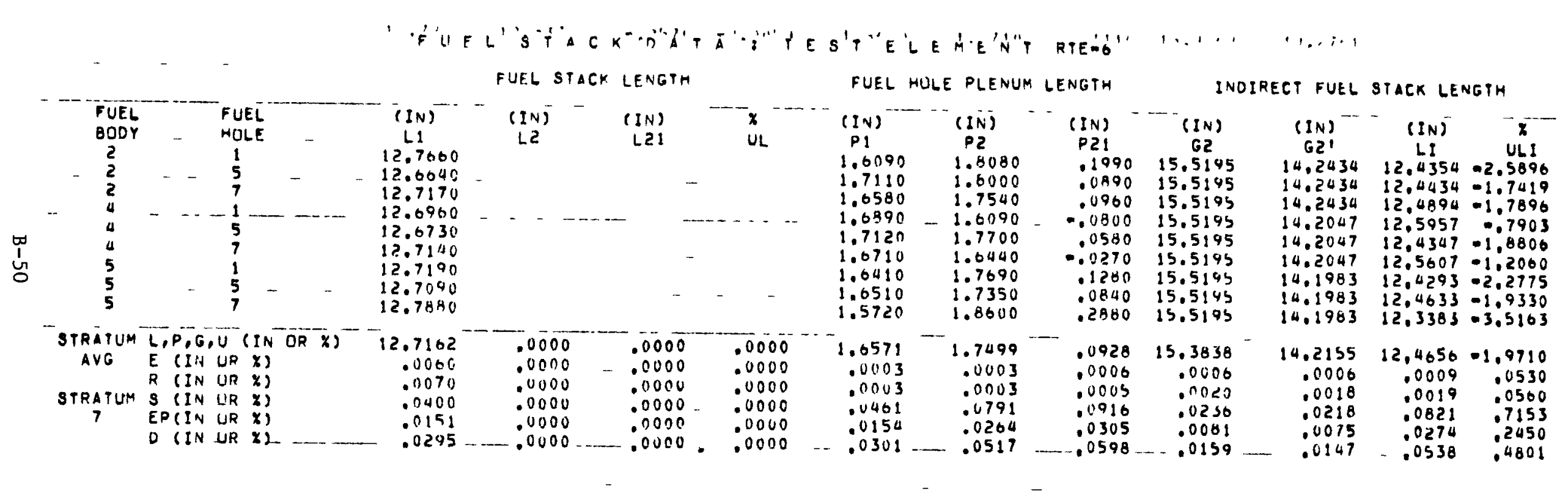


PUACHED CARD OUTRUI FROM STAI SAMPLE DRUALEM RUN

FUEL HOLE

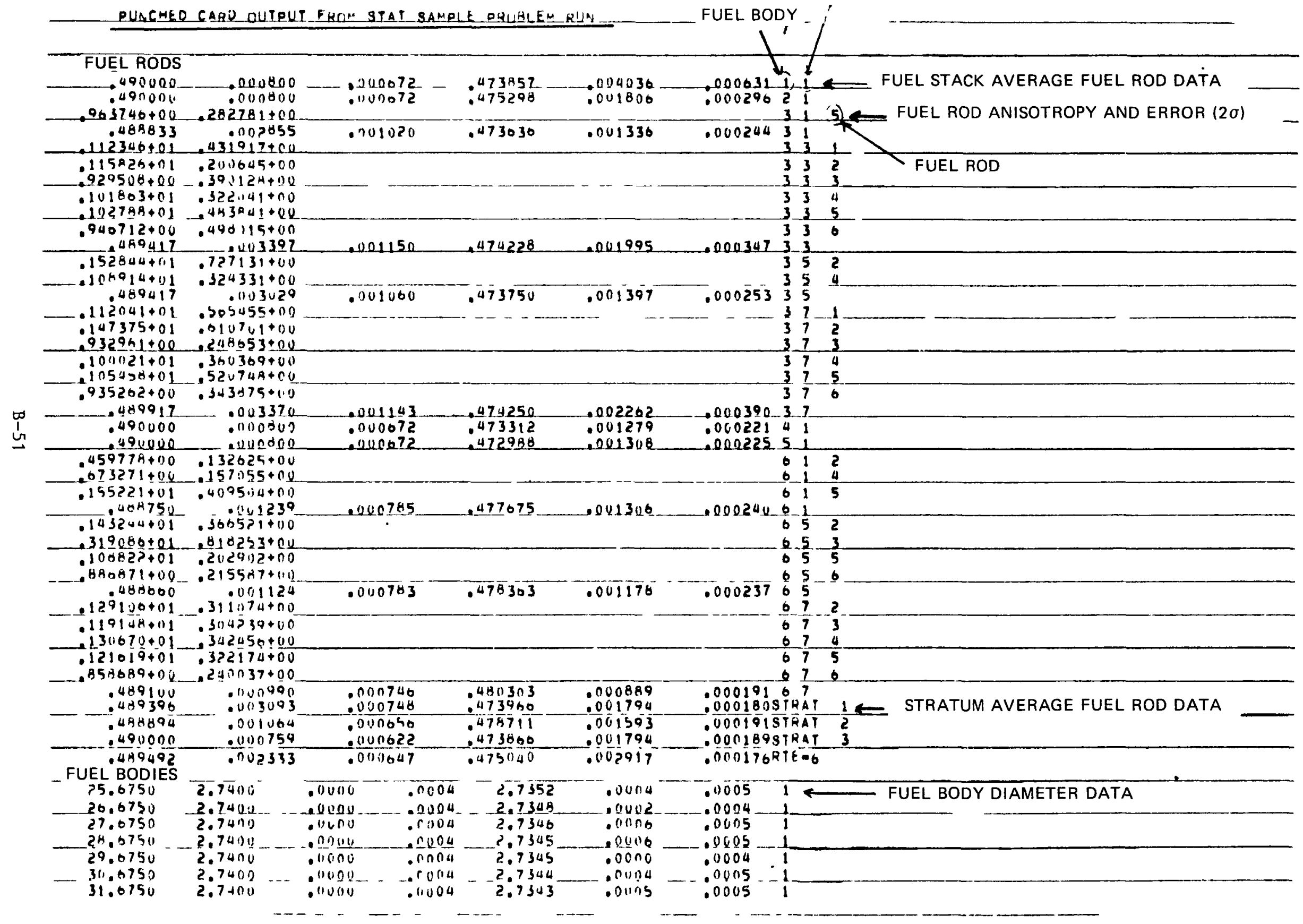




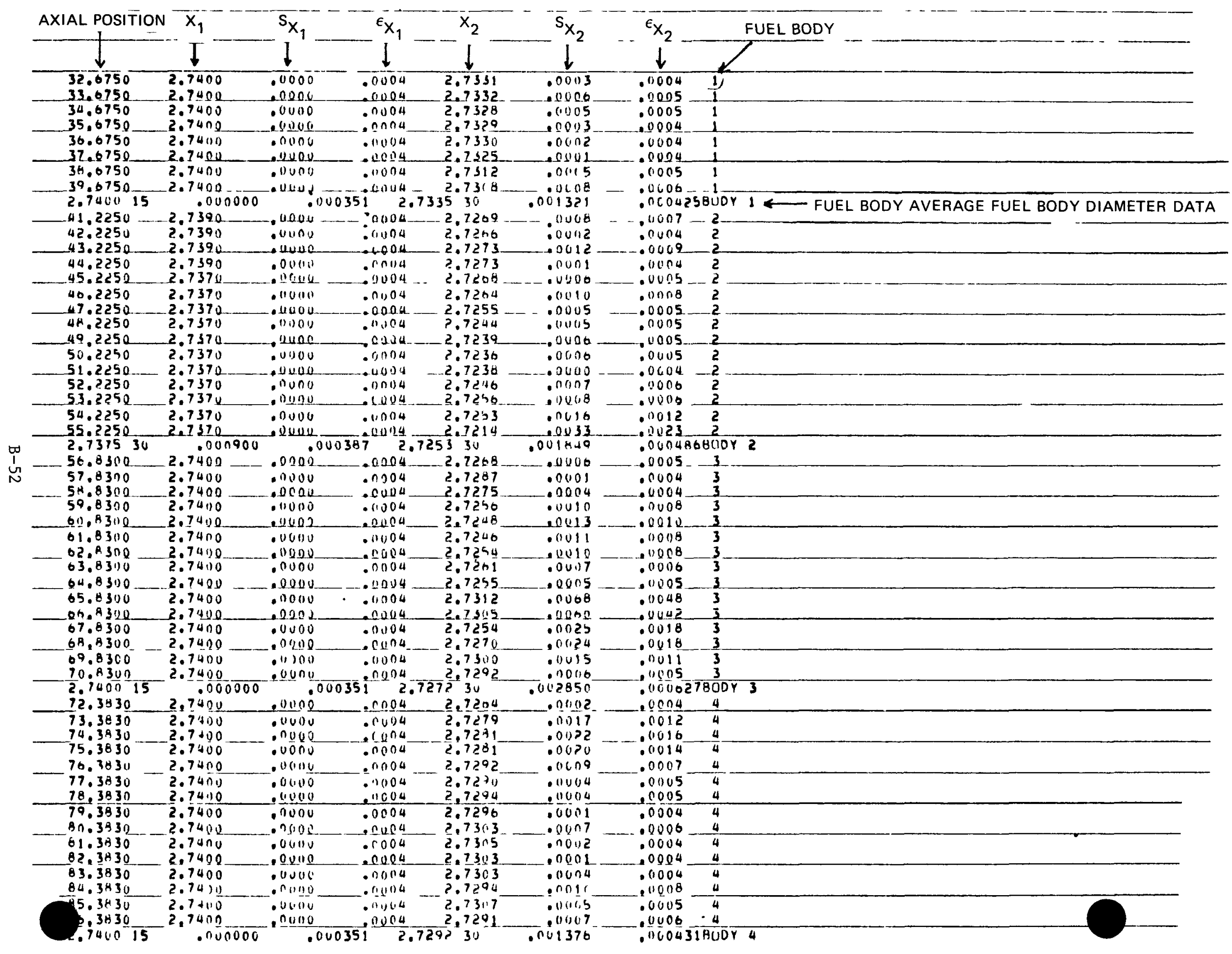




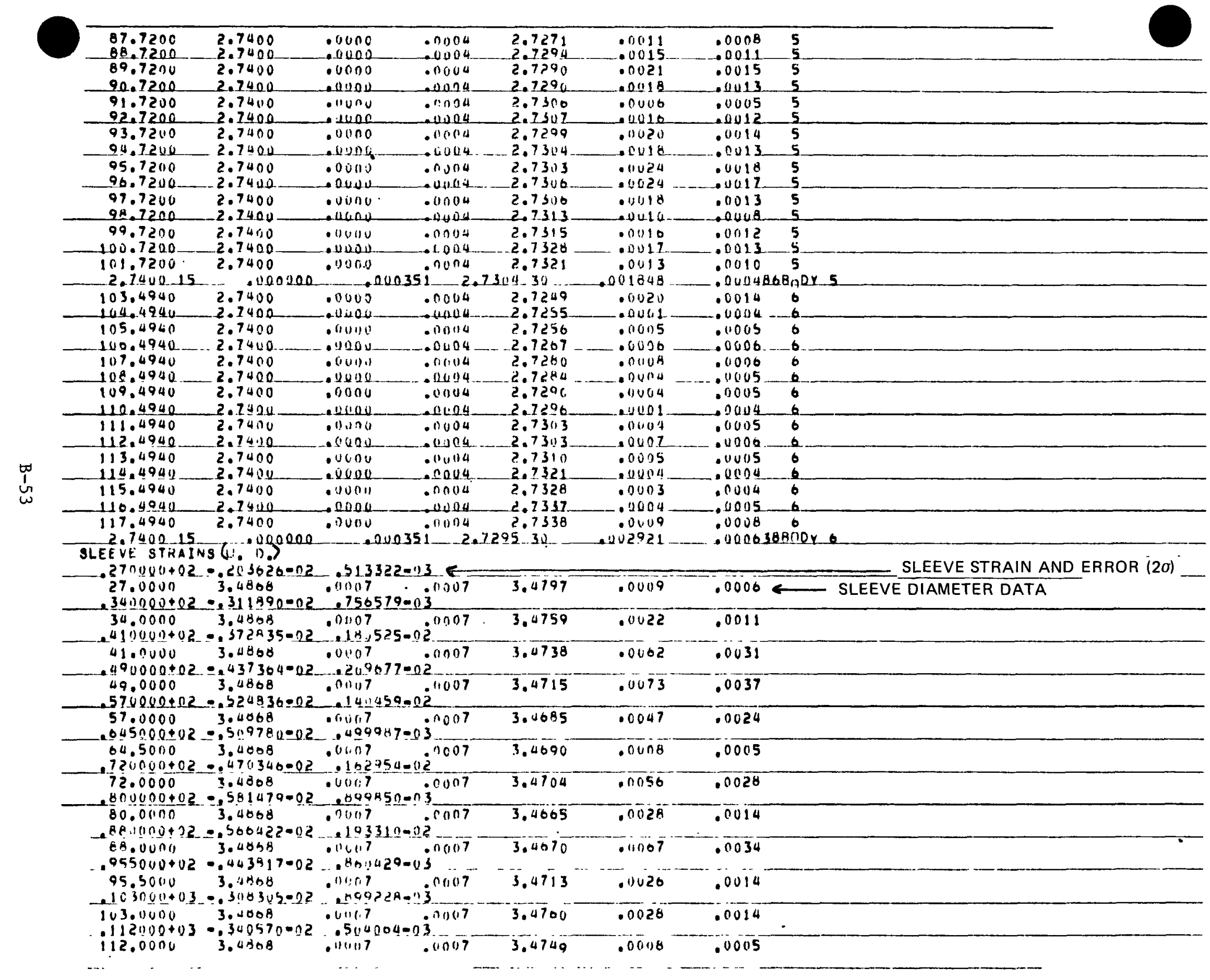




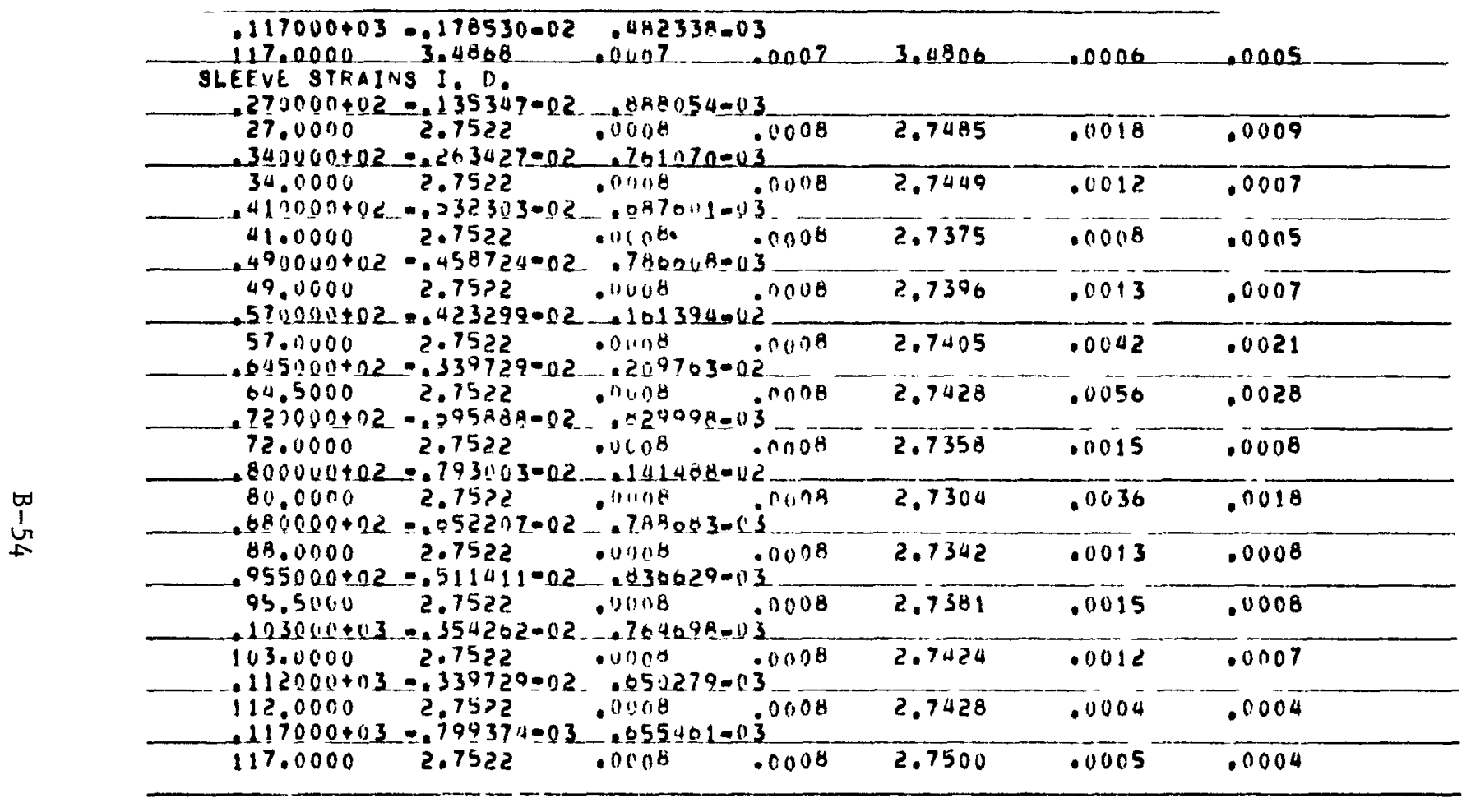


APPENDIX $\mathrm{C}$

STRAIN INPUT INSTRUCTIONS 


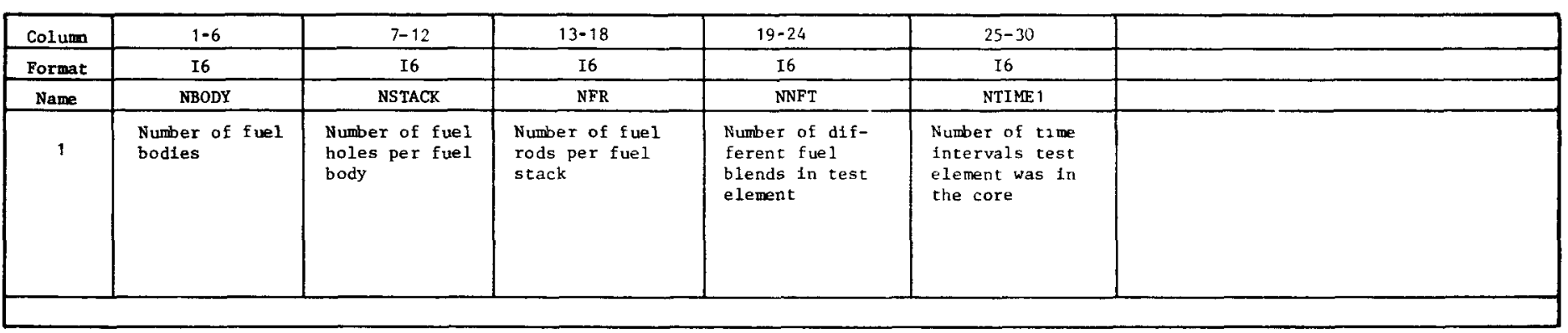

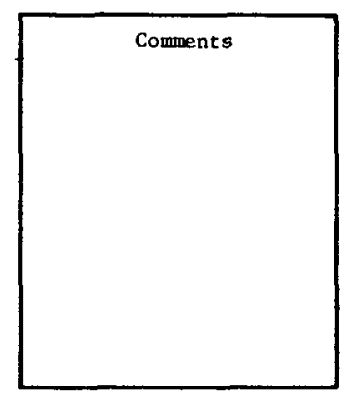

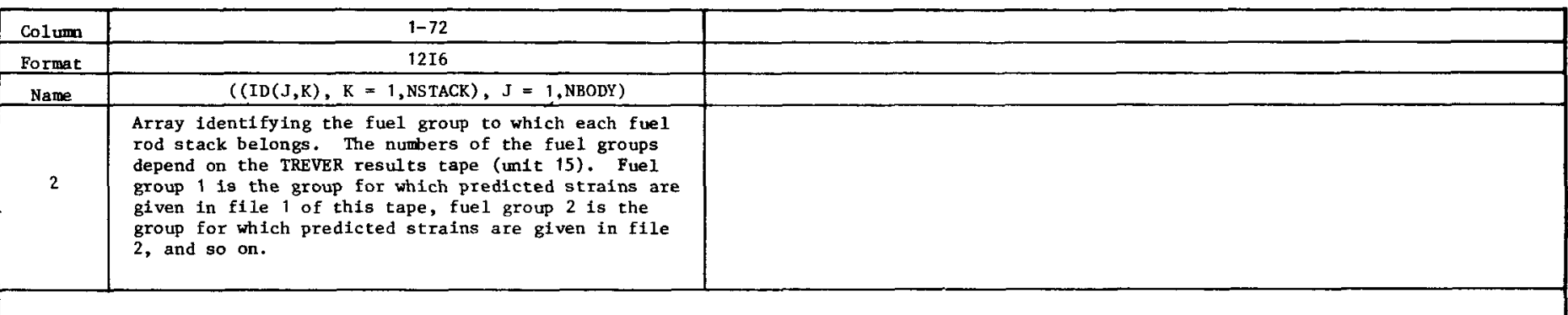

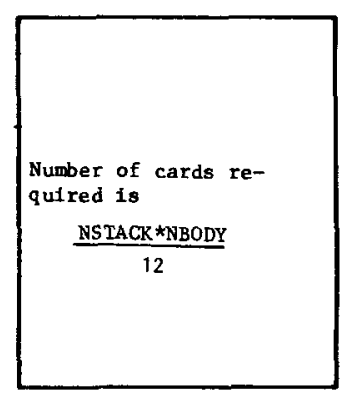

\begin{tabular}{|c|c|l|}
\hline Column & $1-6$ & \\
\hline Format & A6 & \\
\hline Name & FTE & \\
\hline 3 & $\begin{array}{l}\text { Test element } \\
\text { name }\end{array}$ & \\
\hline
\end{tabular}

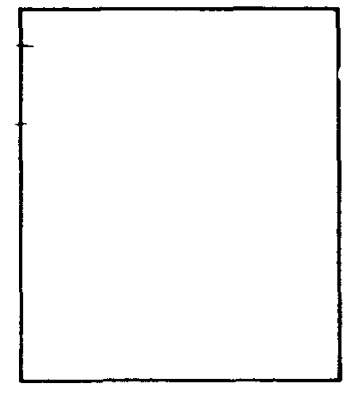



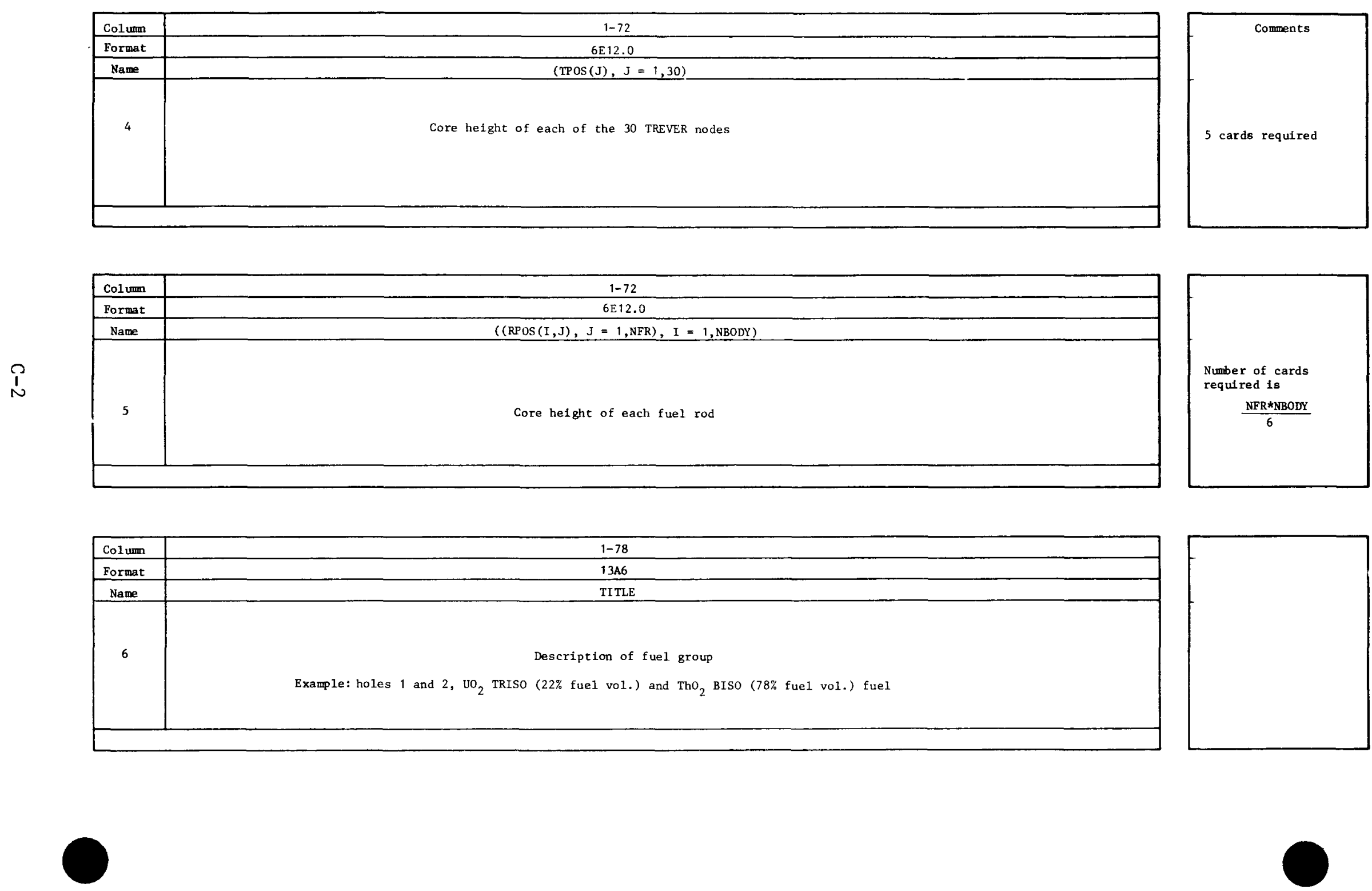


\begin{tabular}{|c|c|}
\hline Columm & $1-78$ \\
\hline Format & $13-\mathrm{A} 6$ \\
\hline Name & TITLE (CONT.) \\
\hline 7 & $\begin{array}{l}\text { If the fuel group consists of two fuel blends having simllar lrradiation-induced stratn } \\
\text { characteristics, the second fuel blend would be described on this card. If the fuel } \\
\text { group consists of only one fuel blend, this card will be blank. }\end{array}$ \\
\hline
\end{tabular}

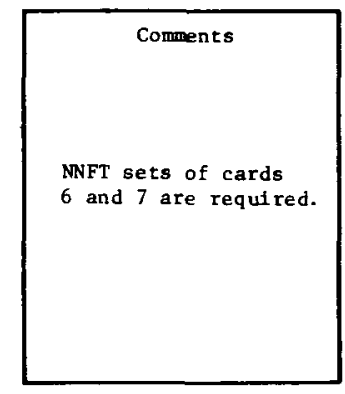

\begin{tabular}{|c|c|c|c|}
\hline Columin & $1-6$ & \multicolumn{1}{|c|}{$7-12$} & \\
\hline Format & I6 & I6 & \\
\hline Name & NX1 & NX2 & \\
\hline 8 & $\begin{array}{l}\text { Number of pre- } \\
\text { irradiation fuel } \\
\text { body diameter } \\
\text { measurements per } \\
\text { measurement } \\
\text { 1ocation }\end{array}$ & $\begin{array}{l}\text { Number of post- } \\
\text { 1rradiation fue1 } \\
\text { body diameter } \\
\text { measurements per } \\
\text { Deasurement } \\
\text { location }\end{array}$ & \\
\hline
\end{tabular}
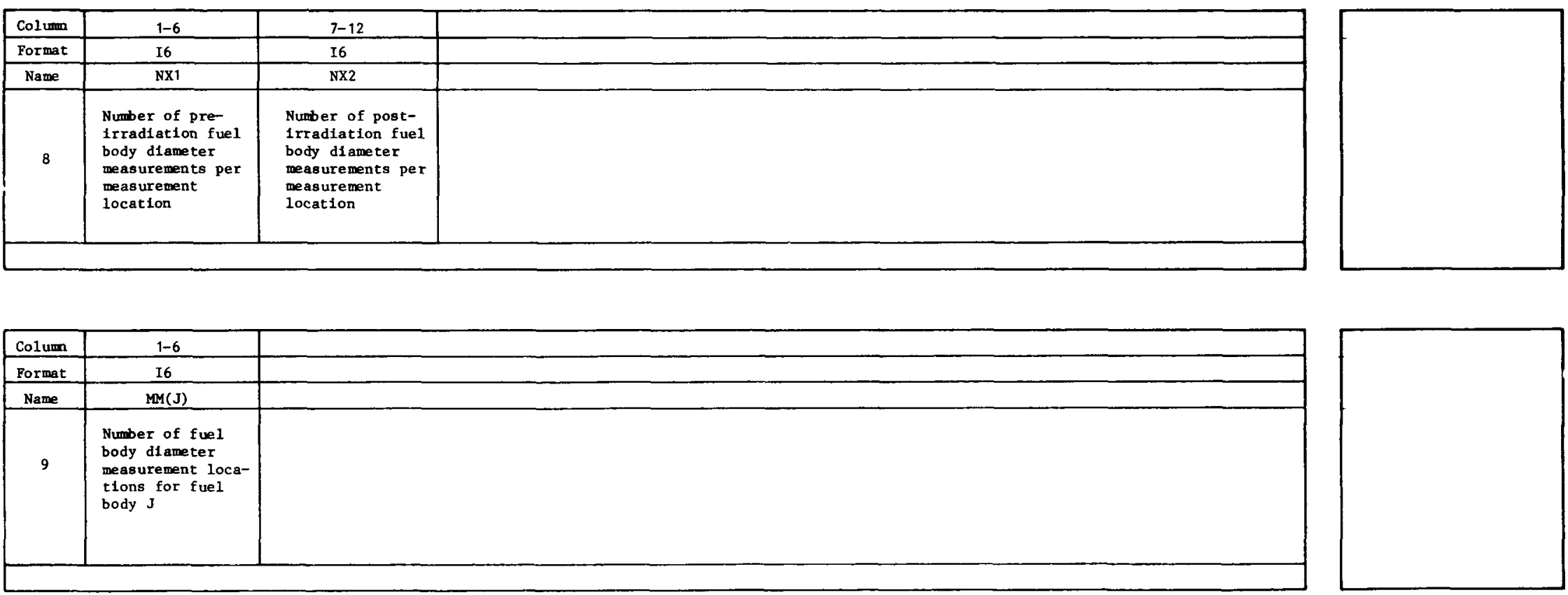


\begin{tabular}{|c|c|c|c|c|c|c|c|}
\hline Col umm & $1-10$ & $11-20$ & $21-30$ & $31-40$ & $41-50$ & $51-60$ & $61-70$ \\
\hline Format & E 10.0 & $E 10.0$ & E10.0 & $E 10.0$ & $E 10.0$ & $E 10.0$ & E10.0 \\
\hline Name & $\mathrm{RPO}(\mathrm{J}, \mathrm{K})$ & $\mathrm{xl}$ & sX1 & EPXI & $\mathrm{x} 2$ & $\mathrm{s \times 2}$ & EPX2 \\
\hline 10 & $\begin{array}{l}\text { Core height of } \\
\text { measurement } \\
\text { location K in } \\
\text { fuel body J } \\
\text { (Inches) }\end{array}$ & $\begin{array}{l}\text { Average pre- } \\
\text { irradiation fuel } \\
\text { body diameter at } \\
\text { measurement } \\
\text { location } K \\
\text { (1nches) }\end{array}$ & $\begin{array}{l}\text { Sample random } \\
\text { error for X1 } \\
\text { (Inches) }\end{array}$ & $\begin{array}{l}\text { Combined random } \\
\text { error for } \times 1 \\
\text { (inches) }\end{array}$ & $\begin{array}{l}\text { Average post- } \\
\text { irradiation } \\
\text { fuel body dianr } \\
\text { eter at meas- } \\
\text { urement } \\
\text { location (Inches) }\end{array}$ & $\begin{array}{l}\text { Sample random } \\
\text { error for } X 2 \\
\text { (Inches) }\end{array}$ & $\begin{array}{l}\text { Combined random } \\
\text { error for } \mathrm{X2} \\
\text { (inches) }\end{array}$ \\
\hline
\end{tabular}

\begin{tabular}{l} 
Comments \\
These cards are punched \\
by the STAT code. \\
MM( $(J)$ of these cards \\
are required for fuel \\
body $J$. \\
NBODY sets of cards \\
8,9, and 10 are \\
required. \\
\hline
\end{tabular}
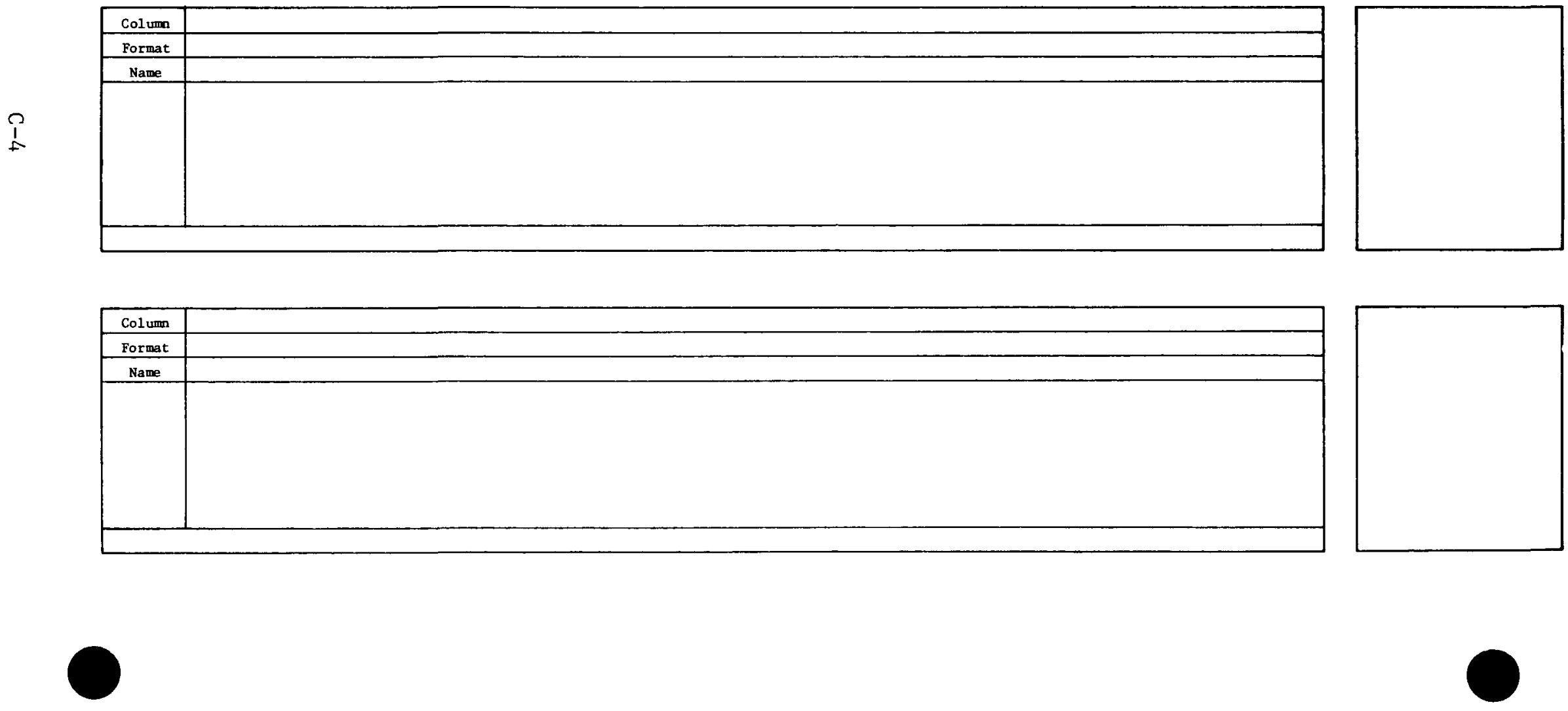
APPENDIX D

STRAIN SAMPLE PROBLEM 


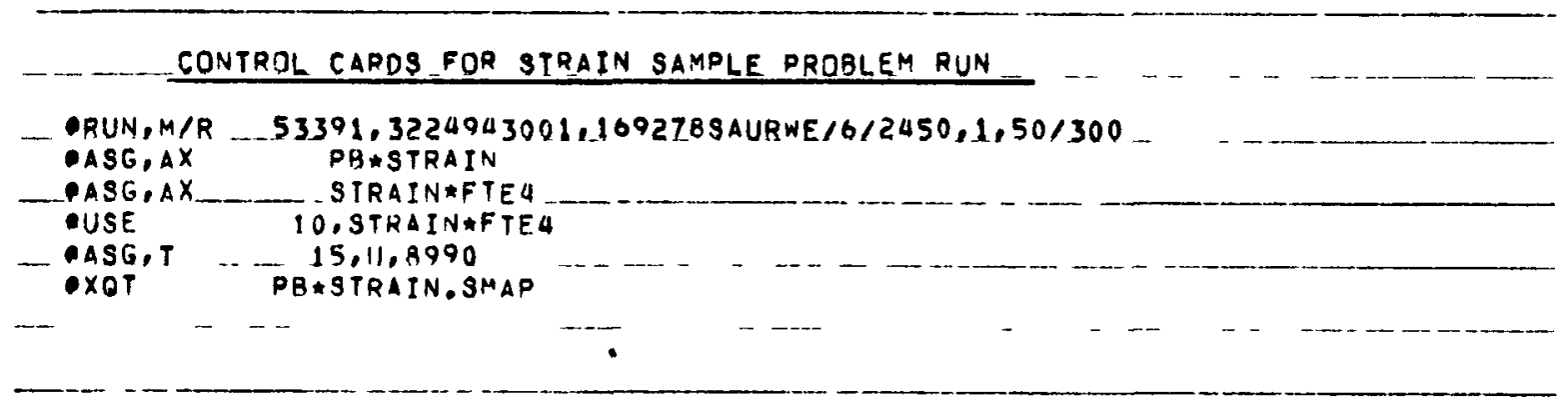

\section{INPÜT DATA DECK FUR STRAIN SAMPLE PRIBLLEM RŨN}

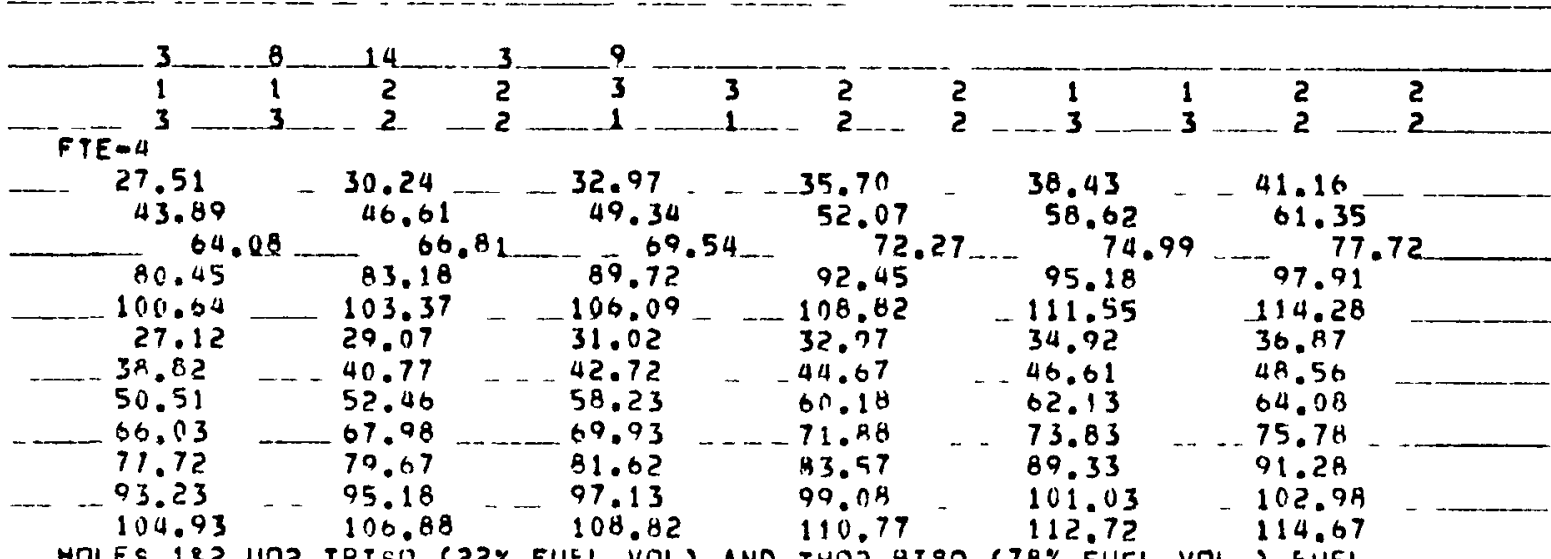

- HOLES ISZ LQ2 TRISI) (22\% FUEL VOL) AND THOZ BISO (78\% FUEL VOL.) FUEL

HOLES 384 (THEUCZ TRISU (78X FUEL YOL.) AND THCZ BISO (2IX FUEL VOL.) FUEL HOLES 788 UCZ TRISO (64\% FUEL VUL.) AND THCZ BISO (36\% FJJEL VOL,) FUEL HOLES 586 (TH,U)C2 TRISO (79X FUEL VDL.) AND THCZ TRISO (2I\% FUEL VOL.) FUEL

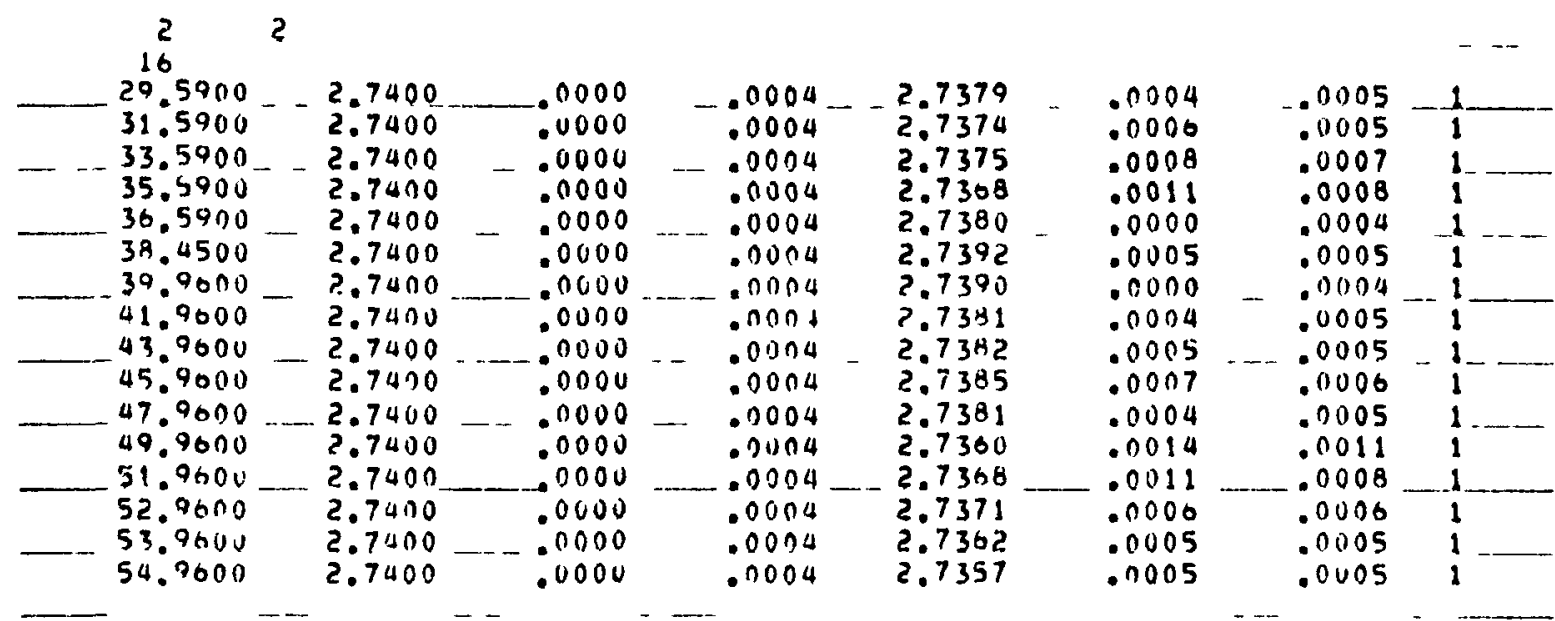




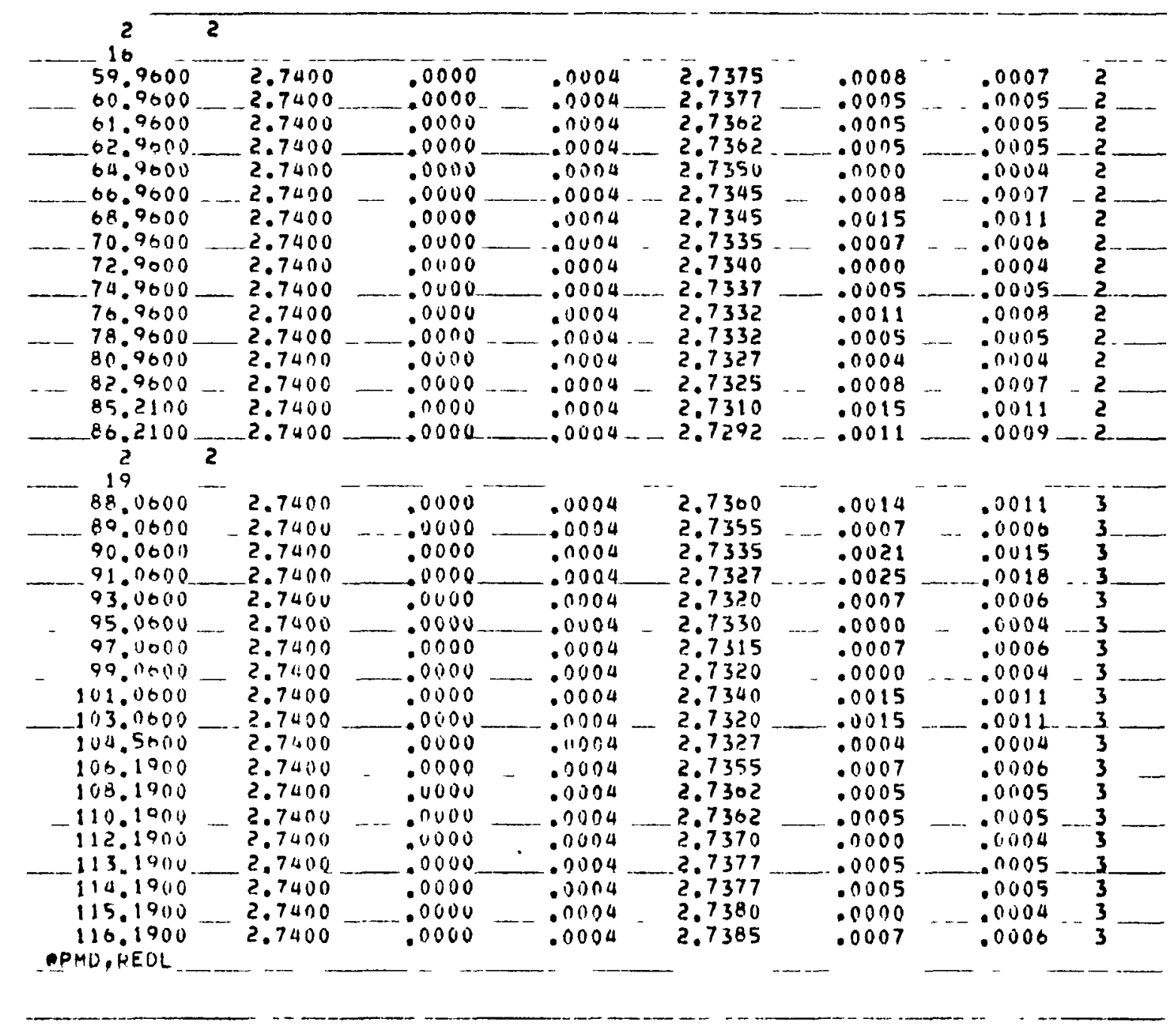

THE NUMBERS APPEARING ON THE RIGHT SIDE OF THE FUEL BODY

DATA CARDS ARE PUNCHED BY STAT TO IDENTIFY THE FUEL BODY.

THESE NUMBERS ARE NOT REQUIRED AS INPUT TO THE STRAIN CODE. 
FTE-A COMPARISON OF MEASURED AND CALCULATED FUEL ROD STRAIN

MOLES 182 UOZ TRISO (22X FUEL VOL) ANO THOZ BISO ( $78 X$ FUEL VOL.) FUEL

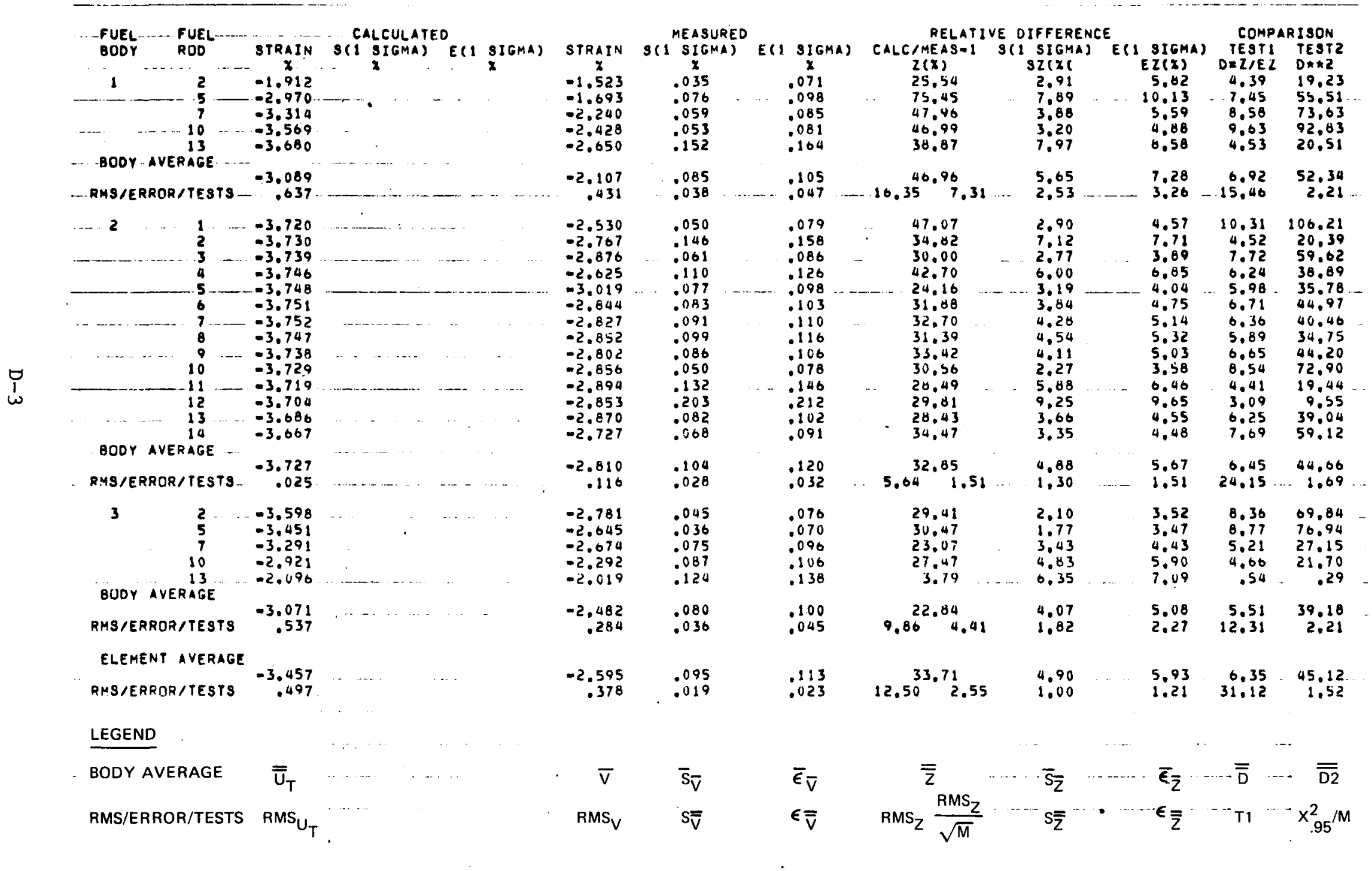

See Tables 3-1 and 3-2 for explanation of symbols. 
FTE- 4 COMPARISUN OF MEASURED AND CALCULATEO FUEL ROD STRAIN

HOLES 384 (TH,U)CZ TRISO (78X FUEL VOL,) AND THC2 BISO (2IX FUEL VUL.) FUEL HOLES 788 UC2 TRISO (64X FUEL VOL.) AND THC2 BISO ( $36 X$ FUEL VOL.) FUEL

FUEL FUel

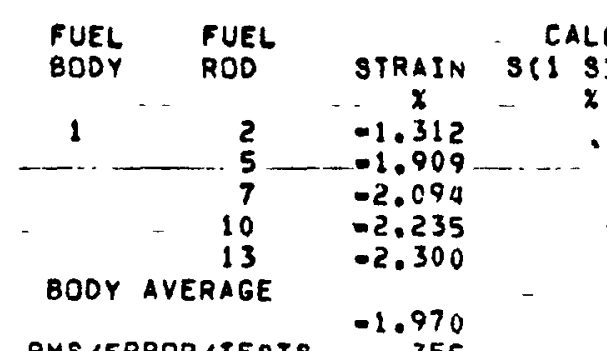

RMSIERRORITESTS -1.970

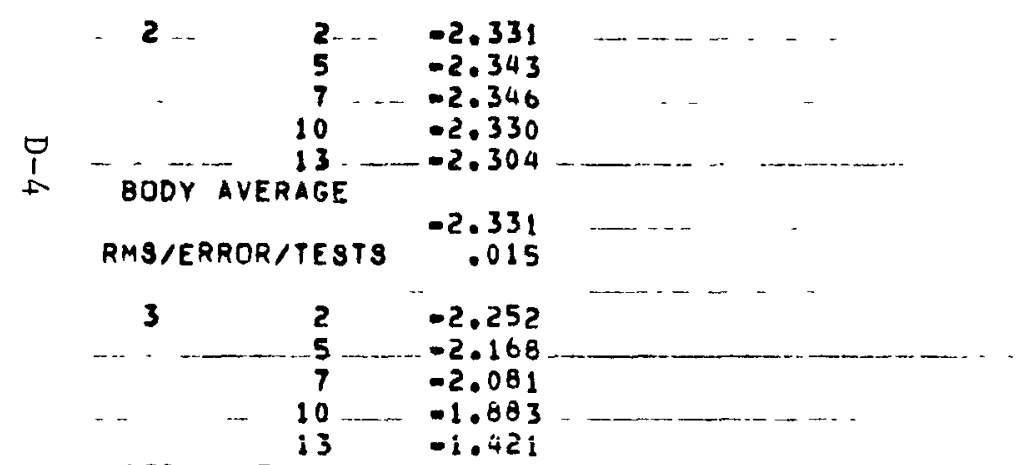

BODY. AVERAGE

RMS/ERRGR/TESTS -1.961

ELEMENT AVERAGE

\begin{tabular}{lr} 
& \\
RMSIERROR/TESTS & $-2.087^{-}$ \\
\hline
\end{tabular}
MEASUREO

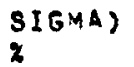

$x^{3}$

STRAIN S(I SIGMA)

$\%$
. .799

$-1.244$

$-1.585$

-1.585
-1.861

-1.861
-1.887

$-1.475$

.410

$-2.122$

$-2.234$

$-2.087$

-1.967
-1.955

$-2.073$

.104

$-2.329$

$-2.015$

$-2.080$

-1.731
-1.459

$-1.923$

-1.923
.300

$-1.82$

.824
.393

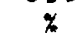

.049

.152

.118

.057
.085

.200

.045

.075

.075
.120

.099

.115
.281

.156

.156
.070

.114

.114
.100

.080

.062

.059

.086

.086
.038

.118
.030
IMEAS-I S(I SIGMA)

$\begin{array}{ll}Z(X) & 32(X) \\ 04.24 & 10.12 \\ 53.50 & 18.79\end{array}$

$\begin{array}{ll}04.24 & 10.12 \\ 53.50 & 18.79\end{array}$

$32.13 \quad 9.83$

20.09

21.90

3.66
5.50

$38.37 \quad 10.92$

.117

.052

.096
.135

.135

.130
.287

$17.56 \quad 7.86$

10.92
4.88

\subsection{7}

9.87
4.88

4.88
12.39

18.47

.0168

.168
.075

.129
.117

.117
.100
.087

.065

.105

.105
.047

12.09

$5.07^{12.69} 2.27$

$-3.32$

7.02
.08

8.77

0.77
-2.56

$5.10^{2.12} 2$.

.133
.034

$18.76^{17.73} 4.84$

8.57
2.21

6.91

16.92

9.05

4.75

5.33

3.84

3.87
3.93

4.38

.034
RELATIVE DIFFERENCE

COMPARISON

$\begin{array}{lll}\text { SIGMA) TESTI } & \text { TESTZ } \\ \text { EZ(X) } & D=Z / E Z & D * 2\end{array}$

$\begin{array}{ccc}16.21 & 3.96 & 15.70 \\ 20.26 & --2.64 & 6.97\end{array}$

$11.06 \quad 2.90 \quad 6.44$

$5.37 \quad 3.74 \quad 13.48$

$6.75 \quad 3.24 \quad 10.51$

$13.19 \quad 3.30 \quad 11.12$

$5.90 \ldots 7.37 \quad 2.21$

$\begin{array}{lll}4.98 & 1.98 \quad 3.92\end{array}$

$6.32 \quad 0.77 \quad 3.60$

$6.28 \quad 1.97 \quad 3.90$

$\begin{array}{lll}7.82 & 2.36 \quad 5.58\end{array}$

7.31

$1.03-.1 .06$

9.64

$\begin{array}{ll}1.62 & 3.01 \\ 3.63 & 2.21\end{array}$

5.37

6.24
4.63

5.45

5.67

-062
$-1.22-1.48$
-.02

$.02 \quad .00$

$\begin{array}{rr}1.01 & 2.59 \\ .0 .45 \quad .20\end{array}$

5.53

$.36-.93$
2.

$\begin{array}{lll}9.96 & 1.76 & 5.02 \\ 2.37 & 6.81 & 1.67\end{array}$ 
FTE-4 COMPARISON OF MEASURED AND CALCULATED FUEL ROO STRAIN

HOLES 586 (TH,U)CZ TRISO (79X FUEL VOL.) AND THCZ TRISO (2IX FUEL VOL.) FUEL

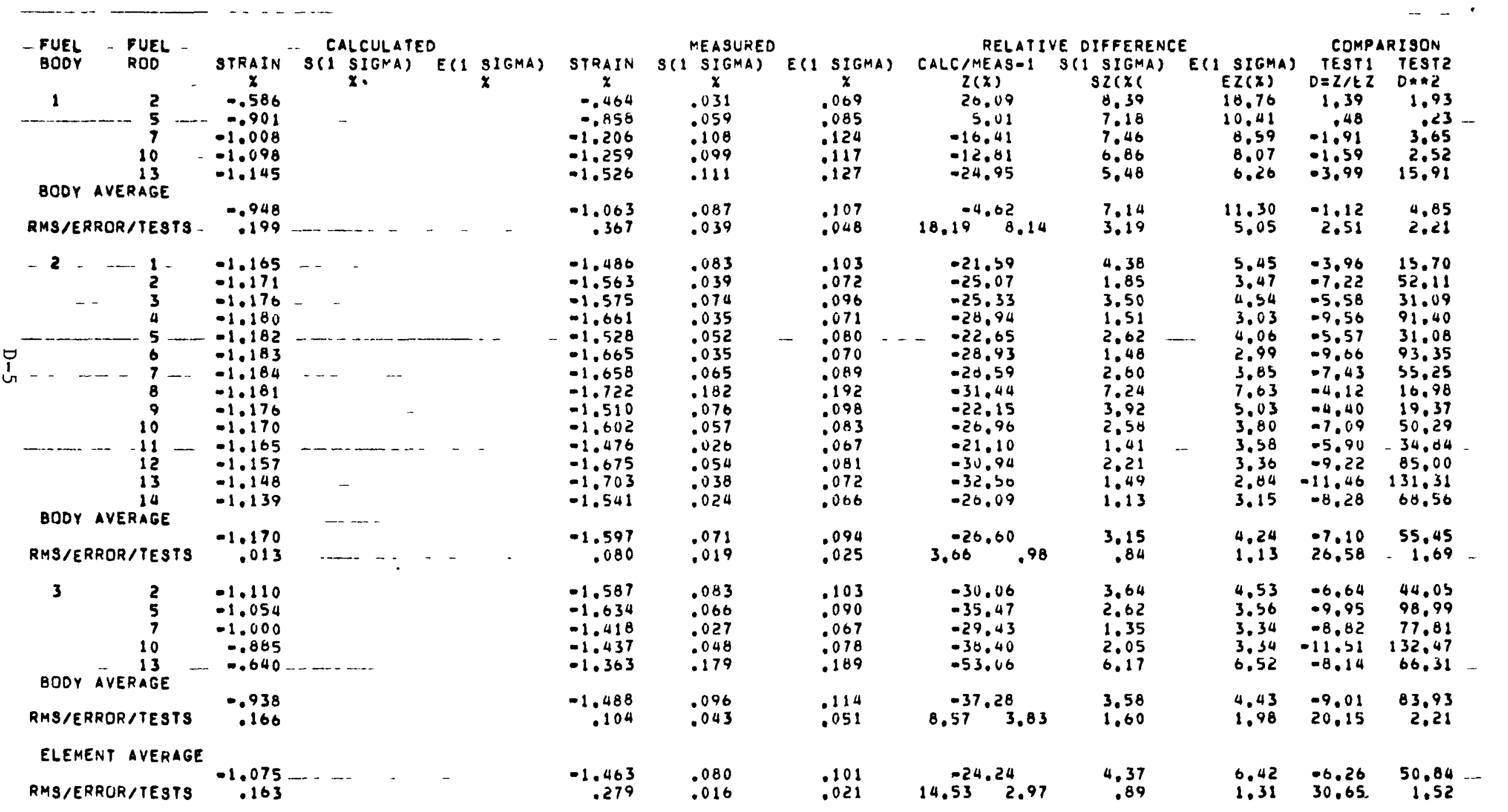


FTE=4 COMPARISON UF MEASURED ANO CALCULATED FUEL BODY SIRAIN

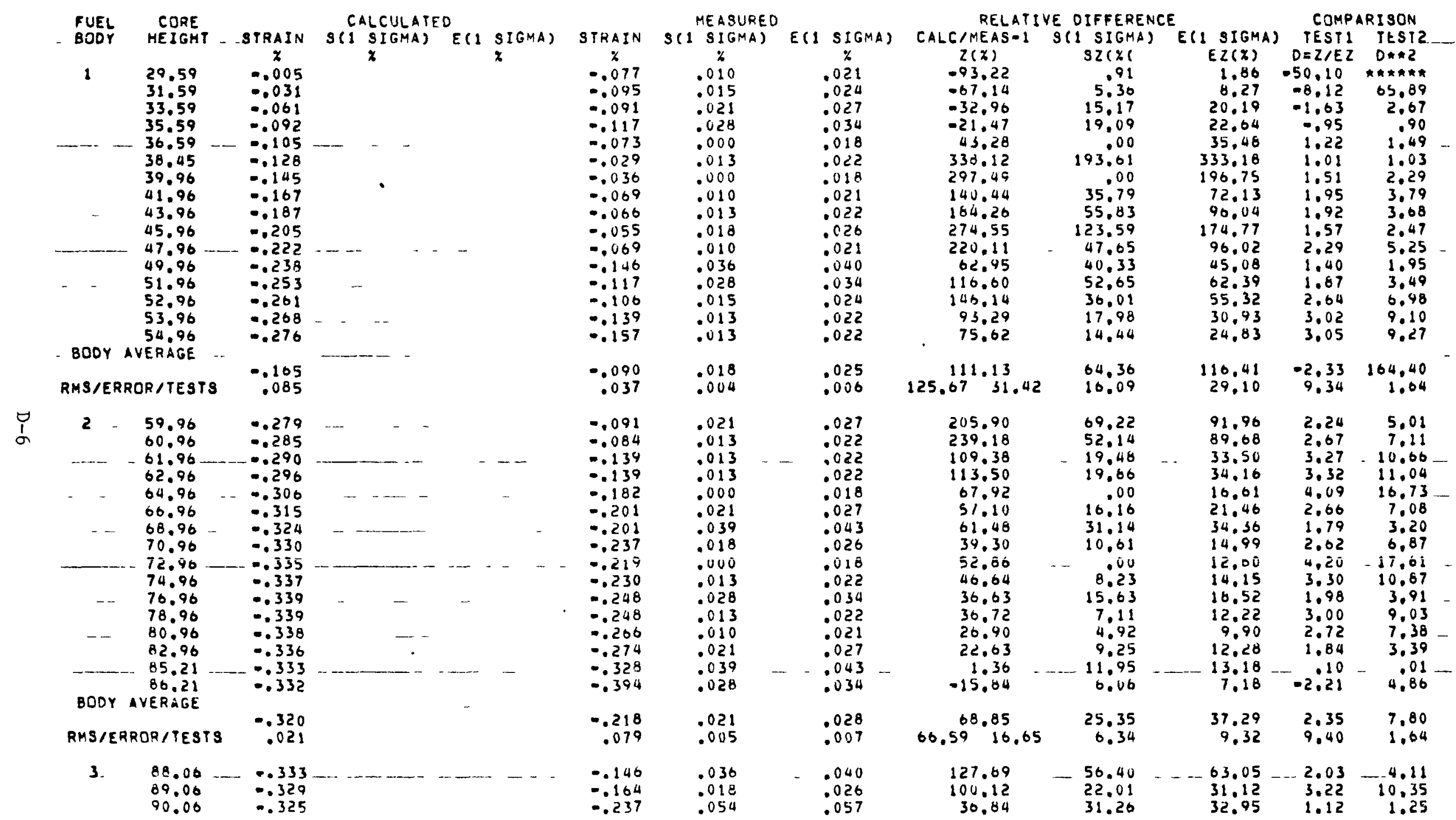




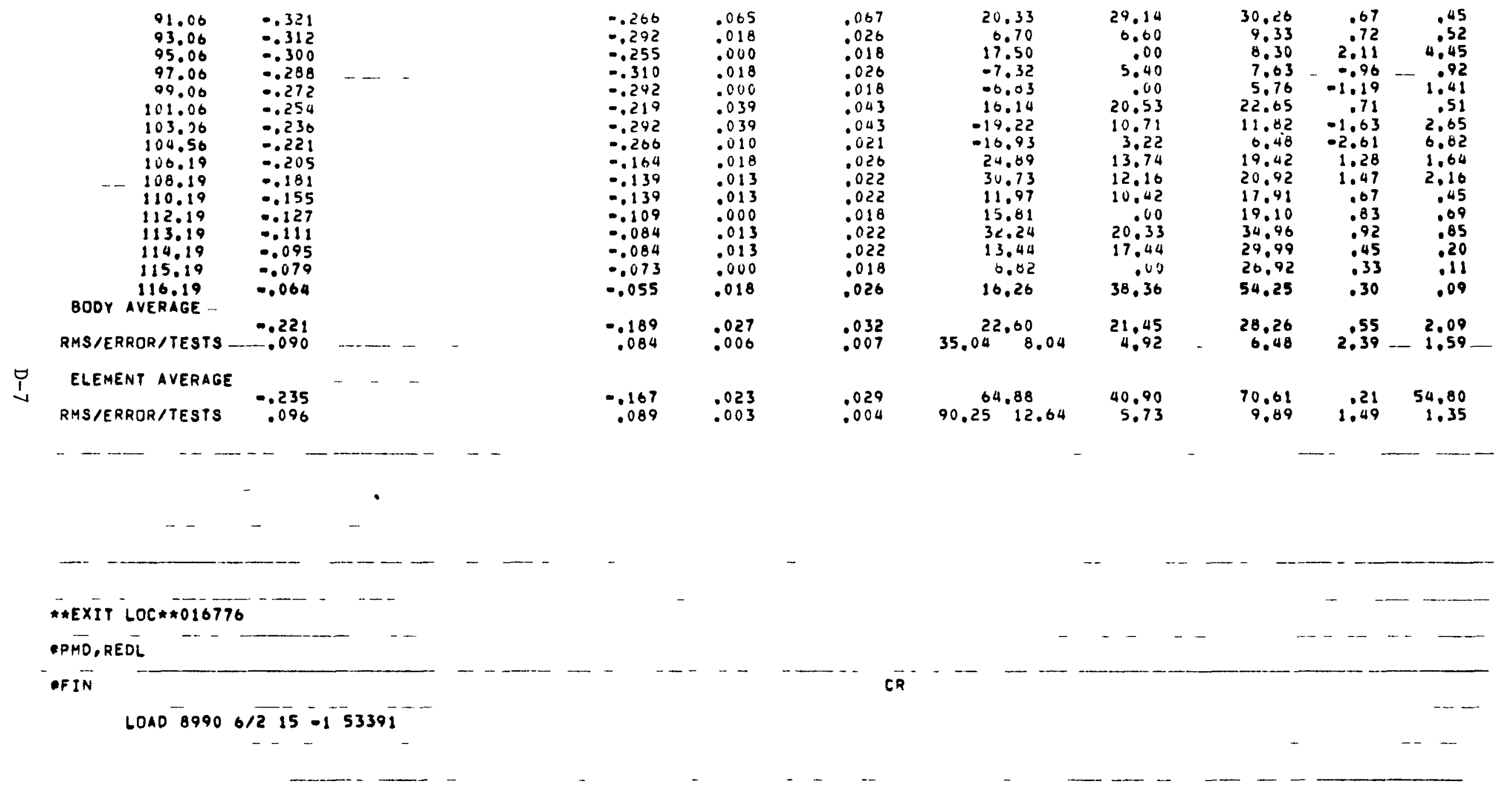




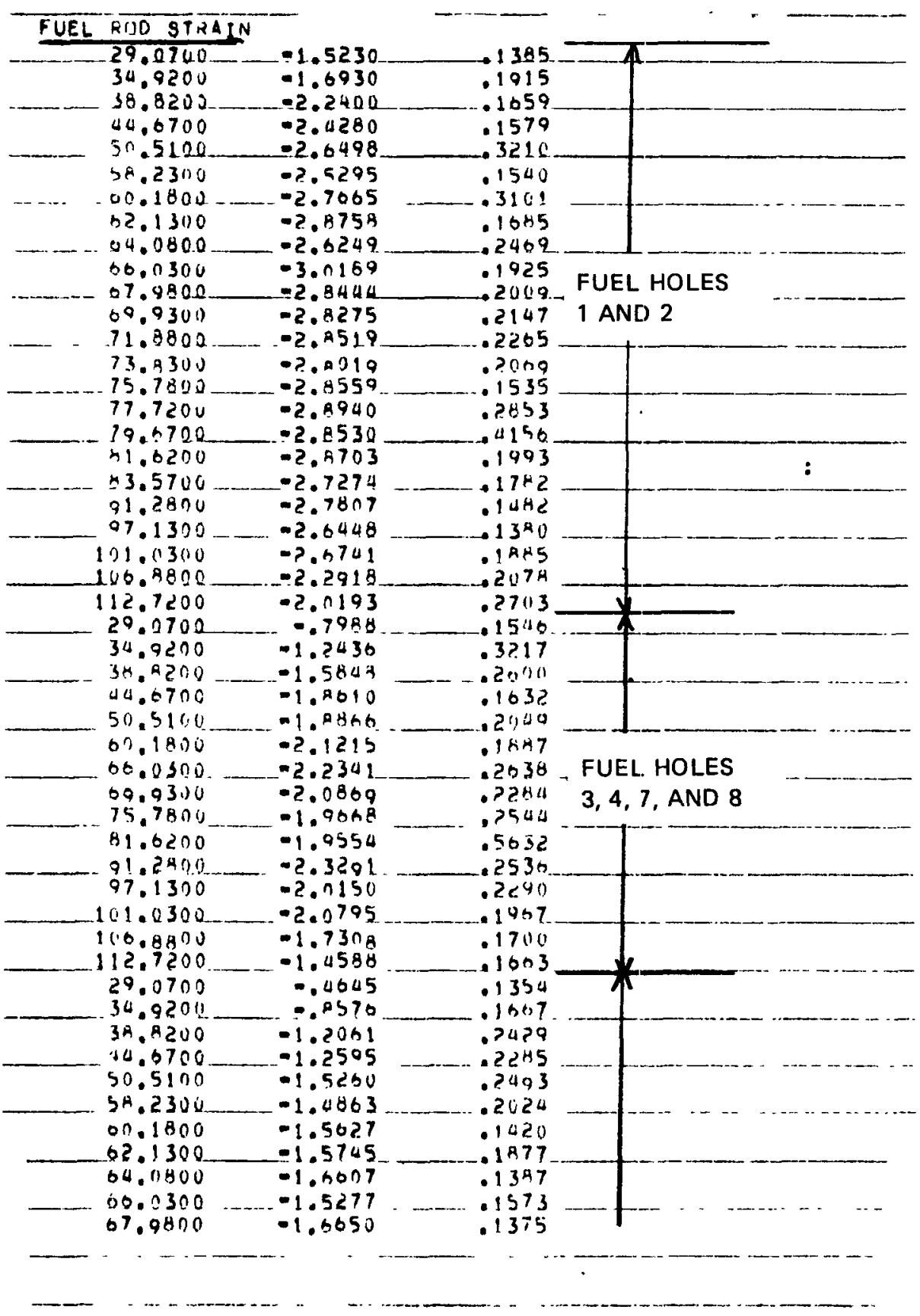




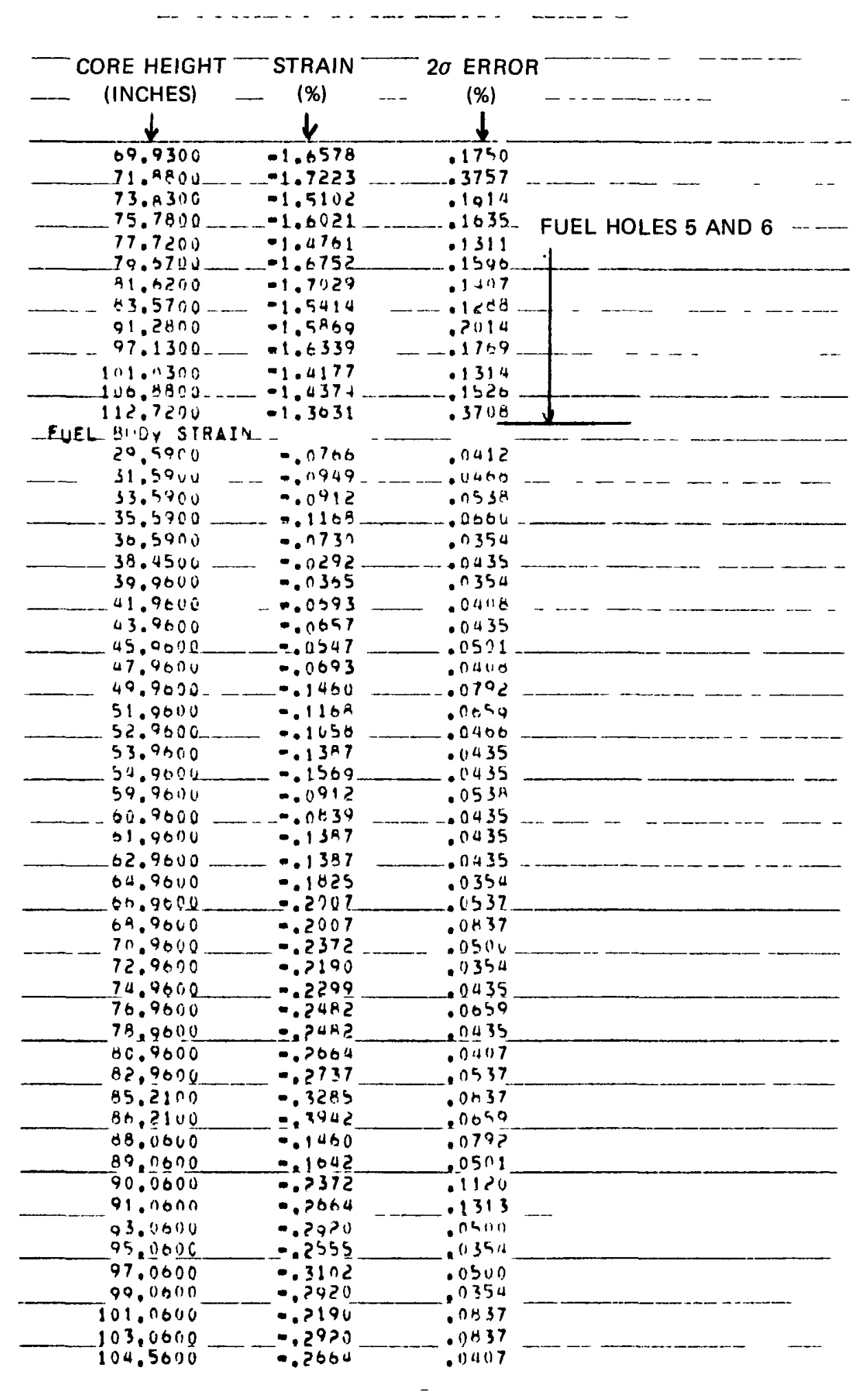




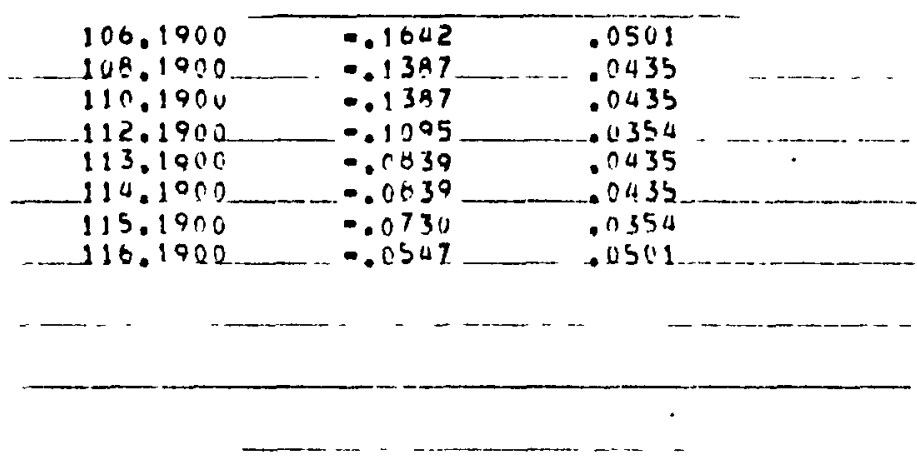


APPENDIX E

GAPS INPUT INSTRUCTIONS 

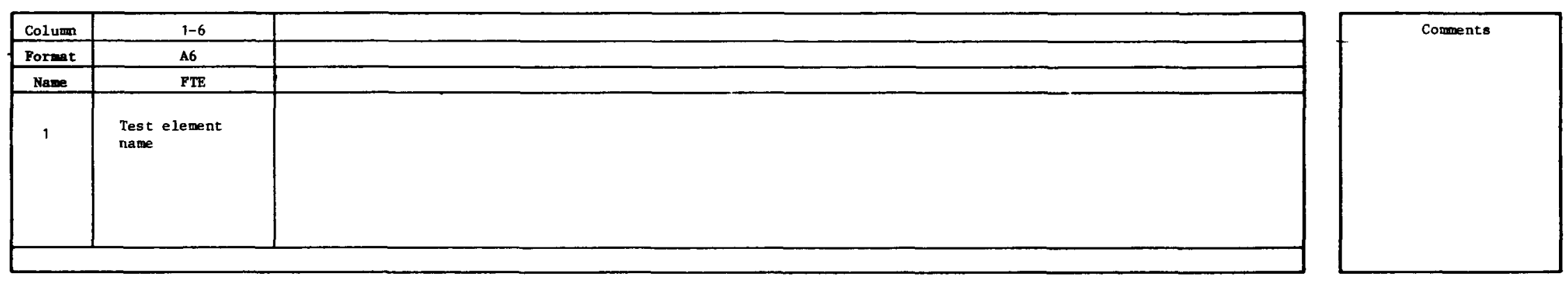

\begin{tabular}{|c|c|c|c|c|c|c|}
\hline Colum & $1-6$ & $7-12$ & $13-18$ & $19-24$ & $25-30$ & \\
\hline Format & 16 & 16 & 16 & 16 & 16 & \\
\hline Name & IOPT(1) & IOPT (2) & $\operatorname{IOPT}(3)$ & $\operatorname{IOPT}(4)$ & $\operatorname{IOPT}(5)$ & \\
\hline 2 & 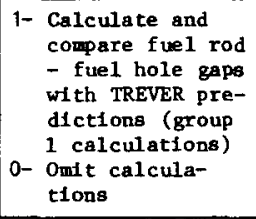 & $\begin{array}{l}\text { 1- Perform fuel rod } \\
\text { - fuel hole gap } \\
\text { calculations } \\
\text { (group } 2 \text { cal- } \\
\text { culations) } \\
\text { o- omt calcur } \\
\text { lations }\end{array}$ & 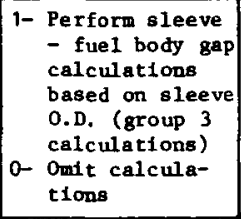 & 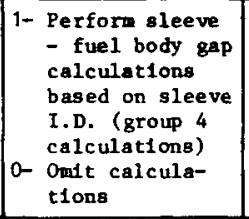 & $\begin{array}{l}\text { 1- Punched output } \\
\text { 0- No punched } \\
\text { output }\end{array}$ & \\
\hline
\end{tabular}

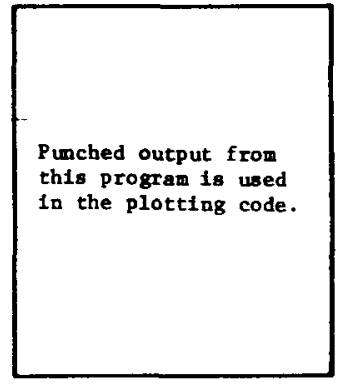

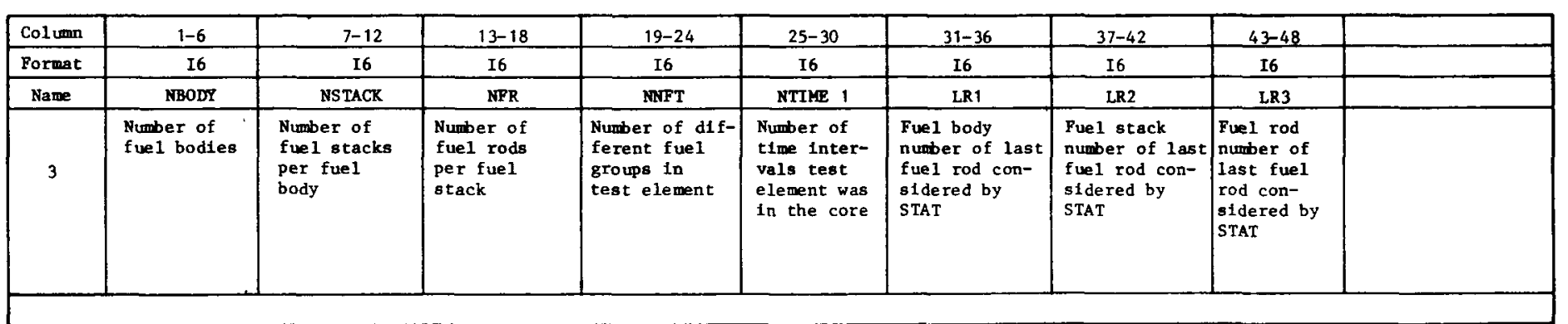

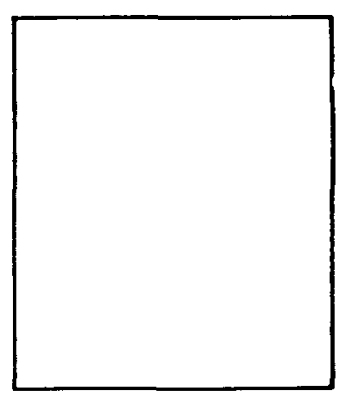




\begin{tabular}{|c|c|}
\hline Columa & $1-72$ \\
\hline Forme & 1216 \\
\hline Name & (NUM(J), J = I, NBODY) \\
\hline & \\
& Number of measurement locations for each fuel body (O.D.) \\
\hline
\end{tabular}
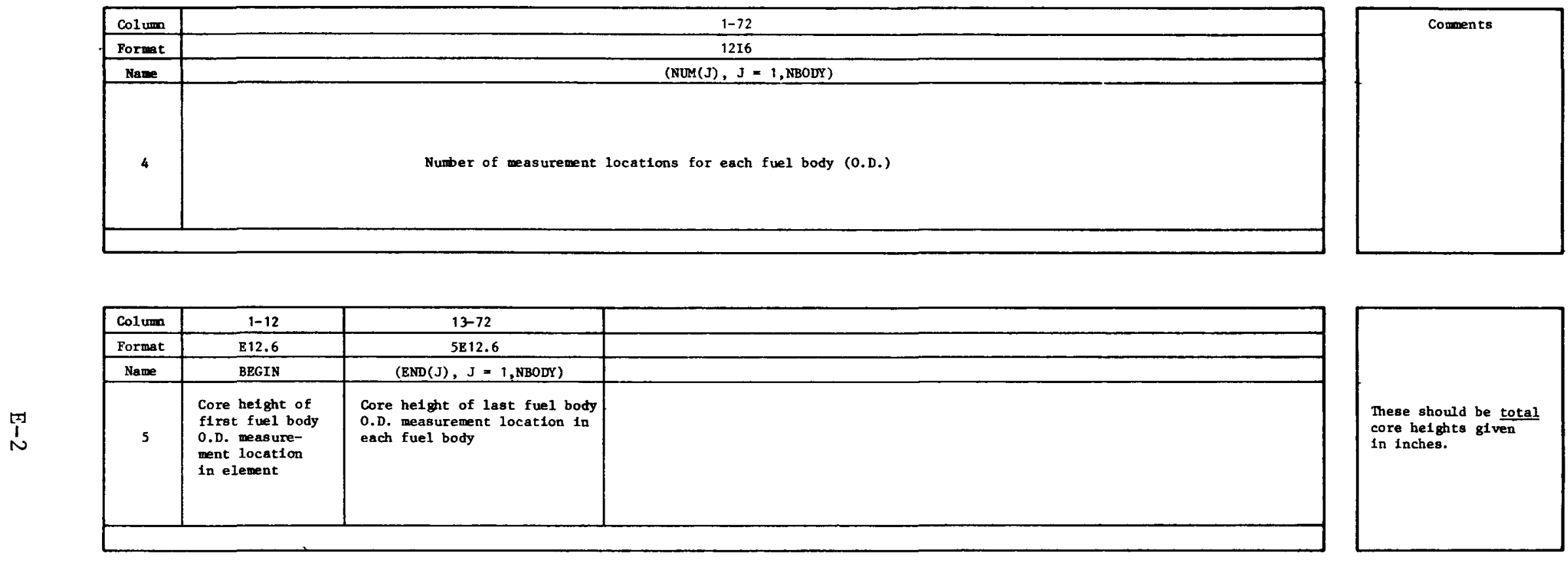

\begin{tabular}{|c|c|c|c|c|}
\hline Col umn & $1-6$ & $7-12$ & $13-72$ & \\
\hline Format & I6 & 16 & 1016 & \\
\hline 6 & $\begin{array}{l}\text { Number of preirra- } \\
\text { diation fuel body } \\
\text { o.D. measurements } \\
\text { per measurement } \\
\text { location in fuel } \\
\text { body } 1\end{array}$ & $\begin{array}{l}\text { Number of postir- } \\
\text { radiation fuel } \\
\text { body } 0.0 \text {. meas- } \\
\text { urements per meas- } \\
\text { urement location } \\
\text { in fuel body } 1\end{array}$ & $\begin{array}{l}\text { Number of preirradiation and postirradiation } \\
\text { fuel body diameter measurements per measurement } \\
\text { location in fuel bodies } 2 \text { through NBODY }\end{array}$ & \\
\hline
\end{tabular}

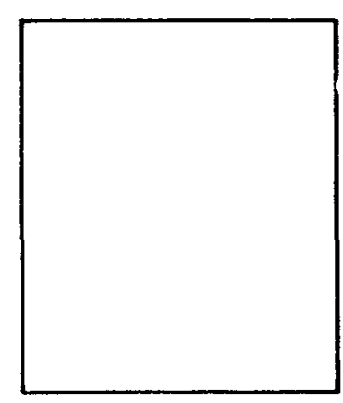




\begin{tabular}{|c|c|c|c|c|c|c|c|}
\hline Column & $1-10$ & $11-20$ & $21-30$ & $31-40$ & $41-50$ & $51-60$ & $61-70$ \\
\hline Format & $\mathrm{E} 10.0$ & E10.0 & $\mathrm{E} 10.0$ & E 10.0 & E 10.0 & $E 10.0$ & E10.0 \\
\hline Name & $\operatorname{BPOS}(I, J)$ & $\operatorname{DFB} 1(\mathrm{I}, \mathrm{J})$ & $\operatorname{SDFB} 1(\mathrm{I}, \mathrm{J})$ & $\operatorname{EDFB1}(\mathrm{I}, \mathrm{J})$ & $\mathrm{DFB} 2(\mathrm{I}, \mathrm{J})$ & $\operatorname{SDFB} 2(1, J)$ & $\operatorname{EDFB} 2(I, J)$ \\
\hline 7 & $\begin{array}{l}\text { Core height of } \\
\text { measurement loca- } \\
\text { tion J in fue I } \\
\text { body I }\end{array}$ & $\begin{array}{l}\text { Prelrradiation } \\
\text { fuel body diameter } \\
\text { at measurement } \\
\text { location J } \\
\text { (average of } \\
\text { NDFB 1 } \\
\text { measurements) }\end{array}$ & $\begin{array}{l}\text { Sample random } \\
\text { error of prefrra- } \\
\text { diation fuel body } \\
\text { diamerer measure- } \\
\text { ments at measure- } \\
\text { ment location J }\end{array}$ & $\begin{array}{l}\text { Comblned randot } \\
\text { error for preirra- } \\
\text { d1ation fuel body } \\
\text { diameter at meas- } \\
\text { urement location } \\
\text { J }\end{array}$ & $\begin{array}{l}\text { Post } 1 \text { rradiation } \\
\text { fue1 body diameter } \\
\text { at measurement } \\
\text { locat } 3 \text { (average } \\
\text { of NDFB2 measure- } \\
\text { ments) }\end{array}$ & $\begin{array}{l}\text { Sample random } \\
\text { error of post- } \\
\text { irradiation fuel } \\
\text { body diameter } \\
\text { measurements at } \\
\text { locarement } \\
\text { location J }\end{array}$ & $\begin{array}{l}\text { Combined random } \\
\text { error for post- } \\
\text { irradiation fuel } \\
\text { body d1ameter } \\
\text { at masurement } \\
\text { location J }\end{array}$ \\
\hline
\end{tabular}

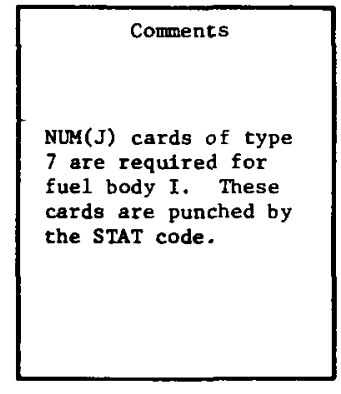

\begin{tabular}{|c|c|c|c|c|c|c|c|c|}
\hline Column & $1-9$ & $10-12$ & $13-24$ & $25-36$ & $37-45$ & $46-48$ & $49-60$ & $61-72$ \\
\hline Format & E9.0 & I3 & E12.0 & E12.0 & $\mathrm{E9} .0$ & $\mathrm{I} 3$ & $\varepsilon 12.0$ & B12. \\
\hline Name & $B 1(I)$ & NB 1 (I) & SBT(I) & $E P B \cap(I)$ & $B 1(I)$ & $\mathrm{NB} 2(\mathrm{I})$ & $\operatorname{SB2}(\mathrm{I})$ & $\operatorname{EPB} 2(I)$ \\
\hline 8 & $\begin{array}{l}\text { Average prelrra- } \\
\text { diation 0.D. for } \\
\text { fuel body } \mathrm{I} \\
\text { (inches) }\end{array}$ & $\begin{array}{l}\text { Total number } \\
\text { of } 0 . \mathrm{D} \text {. meas- } \\
\text { urements for } \\
\text { fuel body I }\end{array}$ & $\begin{array}{l}\text { Sample random } \\
\text { error for } \\
\text { average pre- } \\
\text { irradiation } \\
\text { fuel body O.D. } \\
\text { for fuel body } \\
\text { I (inches) }\end{array}$ & $\begin{array}{l}\text { Combined random } \\
\text { error for av- } \\
\text { erage preirra- } \\
\text { dlation fuel } \\
\text { body O.D. for } \\
\text { fuel body I } \\
\text { (Inches) }\end{array}$ & $\begin{array}{l}\text { Average post- } \\
\text { irradiation 0.D. } \\
\text { for fuel body } \\
\text { I (inches) }\end{array}$ & $\begin{array}{l}\text { Total number } \\
\text { of post1rradi- } \\
\text { ation 0.D. meas- } \\
\text { urements for } \\
\text { fuel body I }\end{array}$ & $\begin{array}{l}\text { Sample random } \\
\text { error for av- } \\
\text { erage post1rra- } \\
\text { diation fuel } \\
\text { body O.D. for } \\
\text { fuel body I } \\
\text { (Inches) }\end{array}$ & $\begin{array}{l}\text { Combined random } \\
\text { error for av- } \\
\text { erage postirra- } \\
\text { dation fuel } \\
\text { body O.D. for } \\
\text { fuel body I } \\
\text { (inches) }\end{array}$ \\
\hline
\end{tabular}

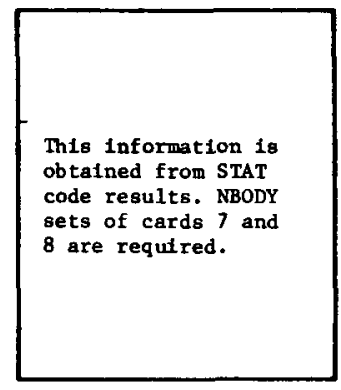

\begin{tabular}{|c|c|c|c|c|c|}
\hline Column & $1-12$ & $13-24$ & $25-36$ & $37-48$ & \\
\hline Format & E12.0 & I12 & E12.0 & E12.0 & \\
\hline Name & FH1(I,J) & NFH1(I,J) & SFH1(I,J) & EPH1(I,J) & \\
\hline 9 & $\begin{array}{l}\text { Preirrad1ation } \\
\text { fuel hole diameter } \\
\text { for fuel hole J, } \\
\text { fue1 body I } \\
\text { (Inches) }\end{array}$ & $\begin{array}{l}\text { Number of meas- } \\
\text { Frements for } \\
\text { FH1 (I,J) }\end{array}$ & $\begin{array}{l}\text { Sample random } \\
\text { error for FH1(I,J) } \\
\text { (Inches) }\end{array}$ & $\begin{array}{l}\text { Combined random } \\
\text { error for } \\
\text { FH1(I,J) (Inches) }\end{array}$ & \\
\hline
\end{tabular}

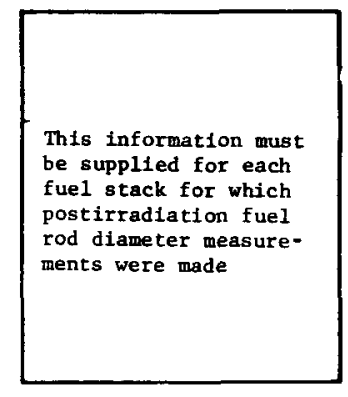




\begin{tabular}{|c|c|}
\hline Column & $1-72$ \\
\hline Format & 1216 \\
\hline Name & $((\operatorname{ID}(\mathrm{J}, \mathrm{K}), \mathrm{K}=1$, NSTACK $), \mathrm{J}=1, \mathrm{NBODY})$ \\
\hline 10 & $\begin{array}{l}\text { Array identifying the fuel group to which each fuel rod stack belongs. The numbers of } \\
\text { the fuel groups depend on the organization of the TREVER results tape (unit 15). Fuel } \\
\text { group } 1 \text { is the group for which predicted strains are given in f1le, of this tape, fuel } \\
\text { group } 2 \text { is the group for which predicted stalns are given in file } 2 \text {, and so on. }\end{array}$ \\
\hline
\end{tabular}

\begin{tabular}{|l|}
\hline \multicolumn{1}{|c|}{ Comments } \\
\\
Only required if \\
OOPT(1) $=1$. \\
Number of cards re- \\
quired is \\
NSTACK NBBOY $_{\text {NBO }}$ \\
12
\end{tabular}
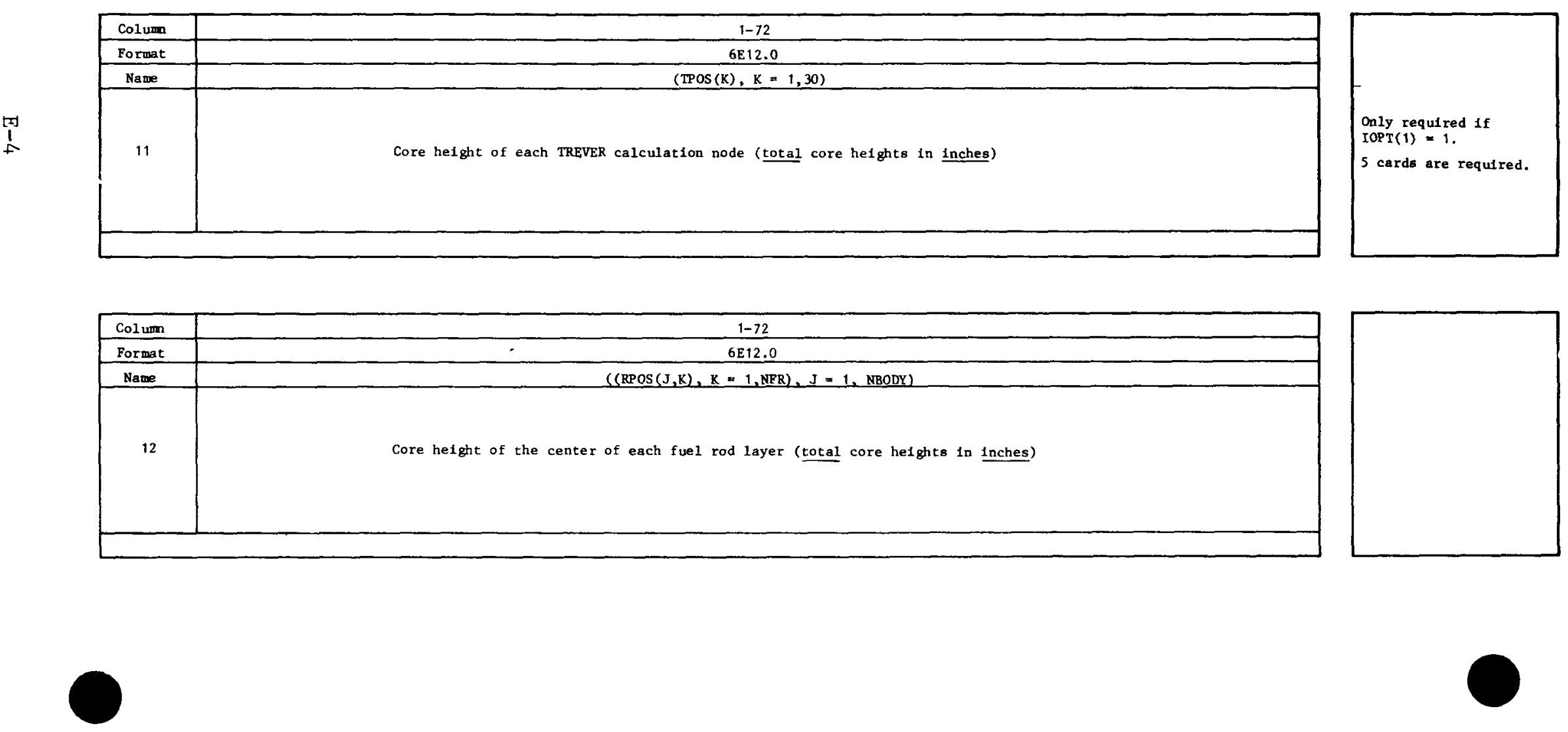


\begin{tabular}{|c|c|}
\hline Column & \\
\hline Format & \\
\hline Name & \\
\hline & \\
& Example: HOLES 1 AND 2, UO 2 TRISO (228 FUEL VOL.) AND THO ${ }_{2}$ BISO (78\% FUEL VOL.) FUEL \\
\hline
\end{tabular}

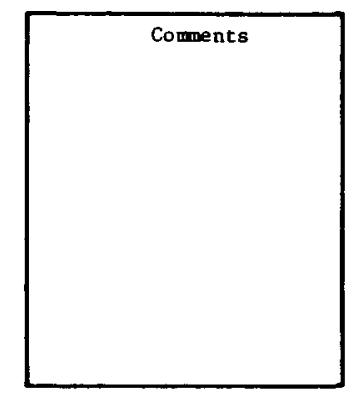

\begin{tabular}{|c|c|}
\hline Colum & $1-78$ \\
\hline Format & $13 \mathrm{~A} 6$ \\
\hline Name & TITLE B (Cont.) \\
\hline 14 & $\begin{array}{l}\text { If the fuel group consists of two fuel blends having similar irradiation-1nduced strain characteristics, } \\
\text { the second fuel blend would be identified on this card. If the fuel group consists of only one fuel } \\
\text { blend, this card will be blank. }\end{array}$ \\
\hline
\end{tabular}

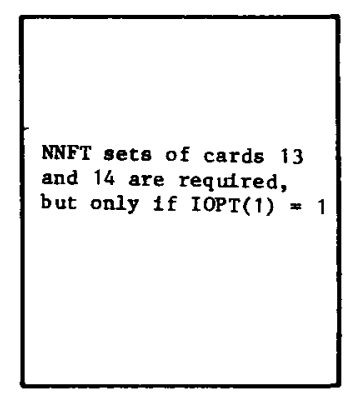

\begin{tabular}{|l|c|}
\hline Column & $1-78$ \\
\hline Format & $13 \mathrm{~A} 6$ \\
\hline Name & TITLE \\
\hline & Heading for fuel rod - fuel hole gaps table. This card should always read: \\
15 & $12 \Delta$ Name $2 \Delta$ FUEL ROD - FUEL HOLE GAPS \\
& $\uparrow$ \\
& Test element name \\
\hline
\end{tabular}

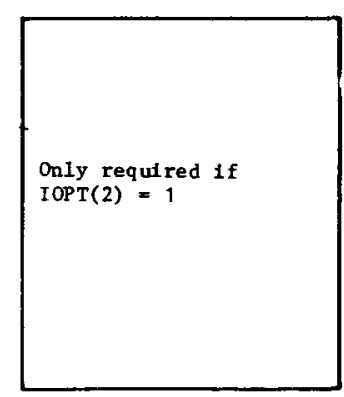




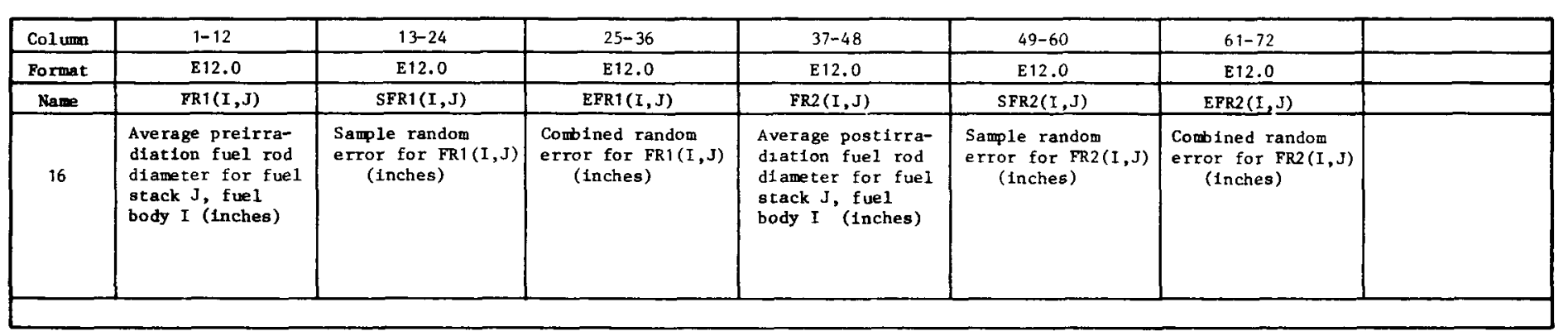

\begin{tabular}{|l|}
\multicolumn{1}{|c|}{ Comments } \\
Only required if \\
IOPT(2) = 1. \\
These cards are punched \\
by the STAT code. \\
A card must be supplied \\
for each fuel stack \\
having postirradiation \\
fuel rod diameter \\
meas urements.
\end{tabular}
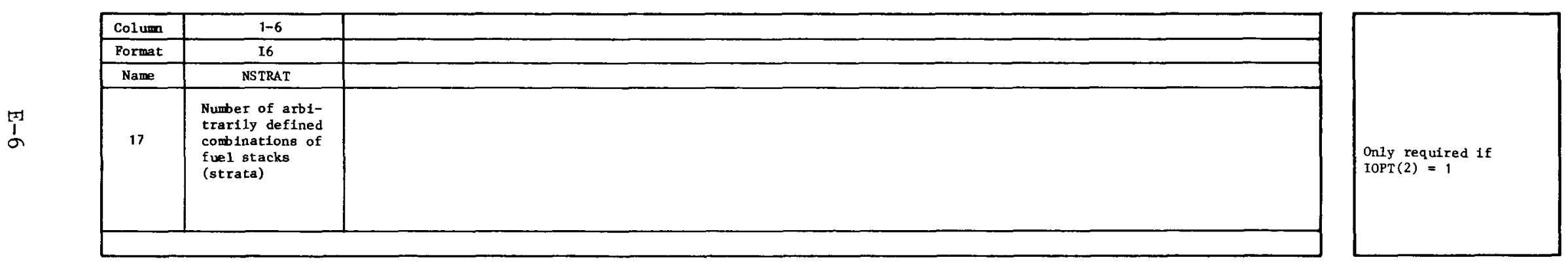

\begin{tabular}{|c|c|c|}
\hline Column & $1-3$ & $4-72$ \\
\hline Format & I3 & 23I 3 \\
\hline Name & NuMB & (IBODY (L), ISTACK (L), L = 1, NUMB) \\
\hline \multirow{4}{*}{18} & $\begin{array}{l}\text { Number of fuel } \\
\text { stacks in } \\
\text { stratum }\end{array}$ & IBODY (L) = body number of fuel stack L \\
& ISTACK (L) = fuel hole number of fuel stack L \\
\hline
\end{tabular}

Only required if

$\operatorname{IOPT}(2)=1$

All fuel stacks* in each

fuel group should be

The last stratu

The last stratum
must 1nclude all fuel

must 1ncl

*All fue1 stacks for which postirradiation fuel rod diameter measurements are avallable. 


\begin{tabular}{|c|c|c|c|c|c|c|}
\hline Col um & $1-12$ & $13-24$ & $24-36$ & $37-48$ & $49-60$ & $61-72$ \\
\hline Format & E12.0 & E12.0 & E12.0 & E12.0 & E12.0 & E12.0 \\
\hline Name & R1 & SR1 & ER1 & $\mathrm{R} 2$ & $\mathrm{SR2}$ & $\mathrm{BR2}$ \\
\hline 19 & $\begin{array}{l}\text { Average prefrra- } \\
\text { diation fuel rod } \\
\text { dameter for } \\
\text { stratum (inches) }\end{array}$ & $\begin{array}{l}\text { Sample random } \\
\text { error for R1 } \\
\text { (Inches) }\end{array}$ & $\begin{array}{l}\text { Combined random } \\
\text { error for ER1 } \\
\text { (inches) }\end{array}$ & $\begin{array}{l}\text { Average postiria- } \\
\text { diation fuel rod } \\
\text { diameter for } \\
\text { stratum (inches) }\end{array}$ & $\begin{array}{l}\text { Sample random } \\
\text { error for R2 } \\
\text { (Inches) }\end{array}$ & $\begin{array}{l}\text { Coublined random } \\
\text { error for R2 } \\
\quad \text { (inches) }\end{array}$ \\
\hline
\end{tabular}

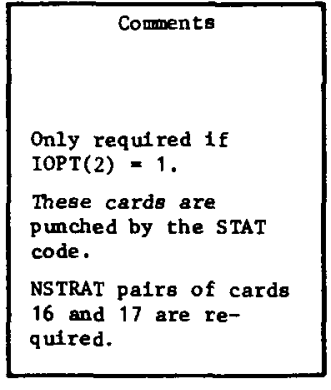

\begin{tabular}{|c|c|c|c|c|c|c|}
\hline Column & $1-12$ & $13-24$ & $24-36$ & $37-48$ & $49-60$ & $61-72$ \\
\hline Format & E12.0 & E12.0 & E12.0 & E12.0 & E12.0 & $E 12.0$ \\
\hline Name & DB 1 & SDB1 & EDB1 & DB2 & SDB2 & EDB2 \\
\hline 20 & $\begin{array}{l}\text { Element average } \\
\text { prelrradiation } \\
\text { fuel body di- } \\
\text { ameter (Inches) }\end{array}$ & $\begin{array}{l}\text { Sample random } \\
\text { error for DB1 } \\
\text { (1nches) }\end{array}$ & $\begin{array}{l}\text { Combined random } \\
\text { error for DB 1 } \\
\text { (Inches) }\end{array}$ & $\begin{array}{l}\text { Element average } \\
\text { postirradiation } \\
\text { fuel body di- } \\
\text { ameter (Inches) }\end{array}$ & $\begin{array}{l}\text { Sample random } \\
\text { error for DB2 } \\
\text { (Inches) }\end{array}$ & $\begin{array}{l}\text { Comb Ined random } \\
\text { error for DB2 } \\
\text { (1nches) }\end{array}$ \\
\hline
\end{tabular}

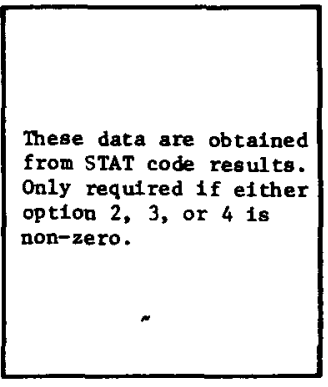

\begin{tabular}{|c|c|}
\hline Column & $1-78$ \\
\hline Format & $13 \mathrm{~A} 6$ \\
\hline Name & TITLE \\
\hline 21 & $\begin{array}{l}\text { Heading for sleeve - fuel body gaps (from sleeve O.D.) table. This card should always read: } \\
17 \Delta \text { Name } 2 \Delta \text { SLEEVE - FUEL BODY GAPS (FROM SLEEVE O.D.) } \\
\uparrow \\
\text { Element name }\end{array}$ \\
\hline
\end{tabular}

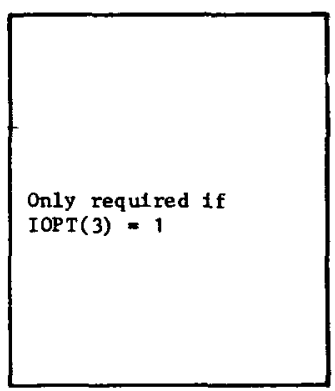



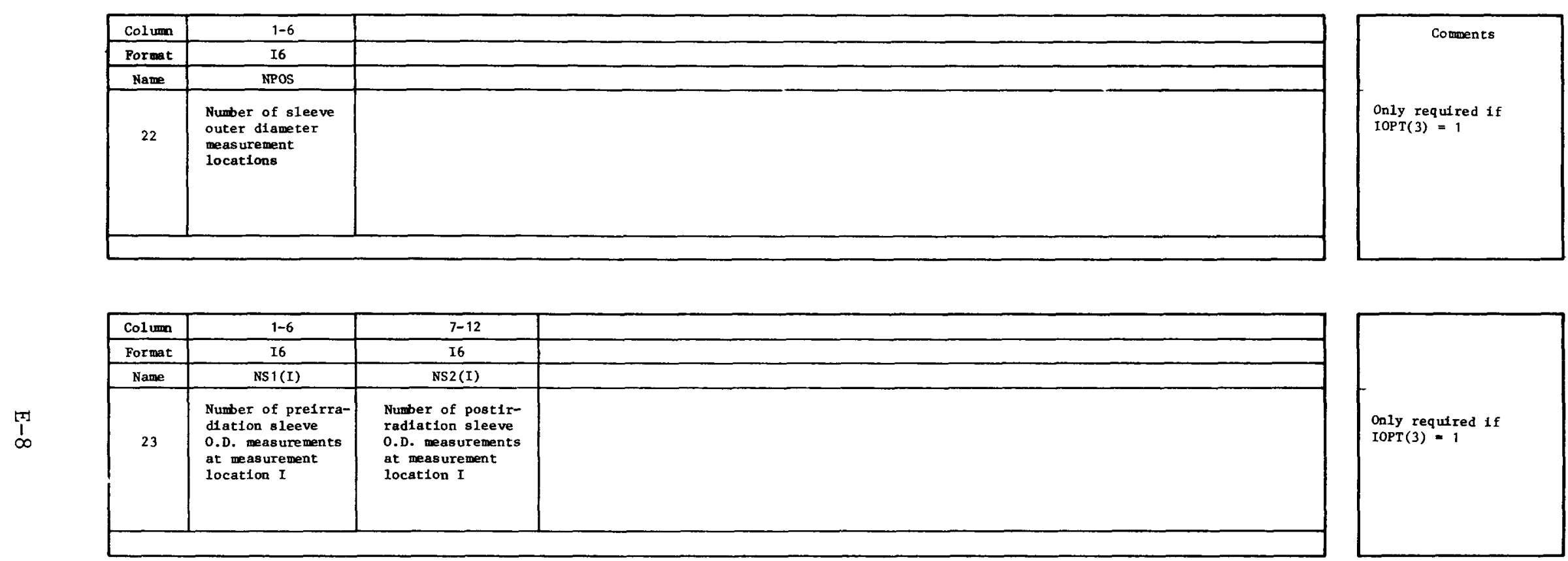

\begin{tabular}{|c|c|c|c|c|c|c|c|}
\hline Column & $1-10$ & $11-20$ & $21-30$ & $31-40$ & $41-50$ & $51-60$ & $61-70$ \\
\hline Format & E10.0 & E10.0 & E10.0 & E10.0 & E10.0 & E10.0 & $E 10.0$ \\
\hline Name & $\operatorname{SPOS}(\mathrm{I})$ & $s 1(\mathrm{I})$ & $\operatorname{ss} 1(1)$ & $\operatorname{ES} 1(\mathrm{I})$ & $\mathrm{S} 2(\mathrm{I})$ & $\operatorname{ss} 2(\mathrm{I})$ & $\operatorname{ES} 2(\mathrm{I})$ \\
\hline 24 & $\begin{array}{l}\text { Core helght of } \\
\text { measurement } \\
\text { location I } \\
\text { (Inches) }\end{array}$ & $\begin{array}{l}\text { Preirradiation } \\
\text { sleeve outer } \\
\text { diameter at meas- } \\
\text { urement location } \\
\text { I (Inches) }\end{array}$ & $\begin{array}{l}\text { Sample random } \\
\text { error for S1(I) } \\
\quad \text { (Inches) }\end{array}$ & $\begin{array}{l}\text { Combined random } \\
\text { error for S1(I) } \\
\text { (inches) }\end{array}$ & $\begin{array}{l}\text { Postirradiation } \\
\text { sleeve outer } \\
\text { daameter at meas- } \\
\text { urement location } \\
\text { I (inches) }\end{array}$ & $\begin{array}{l}\text { Sample randow } \\
\text { error for } S 2(I) \\
\quad \text { (inches) }\end{array}$ & $\begin{array}{l}\text { Combined random } \\
\text { error for } S 2(I) \\
\text { (1nches) }\end{array}$ \\
\hline
\end{tabular}

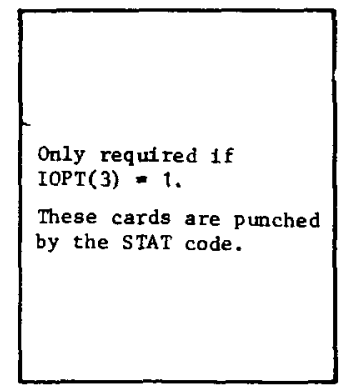




\begin{tabular}{|c|c|c|c|c|}
\hline Colum & $1-12$ & $13-24$ & $25-36$ & \\
\hline Pormst & E12.0 & $\mathrm{E} 12.0$ & E12.0 & \\
\hline Name & SI1 & SSI1 & ESII & \\
\hline 25 & $\begin{array}{l}\text { Preirradiation } \\
\text { sleeve 1nner } \\
\text { diameter at } \\
\text { measurement } \\
\text { location I } \\
\text { (Inches) }\end{array}$ & $\begin{array}{l}\text { Sample random } \\
\text { error for } \\
\text { SI1 } \\
\text { (Inches) }\end{array}$ & $\begin{array}{l}\text { Combined random } \\
\text { error for sI1 } \\
\text { (inches) }\end{array}$ & \\
\hline
\end{tabular}

Comments
Only requi red 1f
IOPT (3) $=1$.
NPos sets consisting
of cards 23 , 24, and
25 are required.

\begin{tabular}{|c|c|c|c|c|}
\hline Colum & $1-12$ & $13-24$ & $25-36$ & \\
\hline Pormat & E12.0 & E12.0 & $E 12.0$ & \\
\hline Name & SI1 & SSI1 & ESI1 & \\
\hline 26 & $\begin{array}{l}\text { Average preirra- } \\
\text { diattion 1nner } \\
\text { sleeve diameter } \\
\text { for fuel body } \\
\text { I (Inches) }\end{array}$ & $\begin{array}{l}\text { Sample random } \\
\text { error for } \\
\text { SI1 (Inches) }\end{array}$ & $\begin{array}{l}\text { Combined random } \\
\text { error for sII } \\
\text { (Inches) }\end{array}$ & \\
\hline
\end{tabular}

\section{Only required if}

$\operatorname{IOPT}(3)=1$.

Required for each fuel

brads has a post-

o. D. measurement.

These data are

obtained by hand
calculations

calculations.
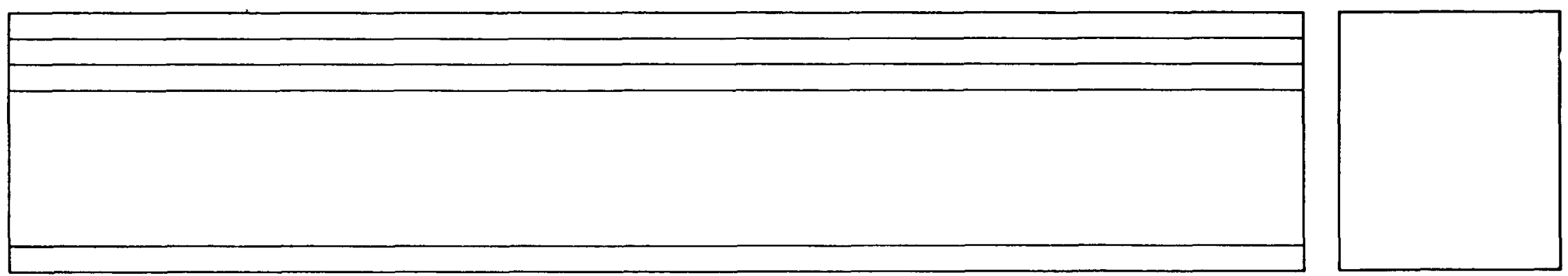


\begin{tabular}{|c|c|c|c|c|}
\hline Column & $1-12$ & $13-24$ & $25-36$ & \\
\hline Format & E12.0 & E12.0 & E12.0 & \\
\hline Name & SI1 & SSI1 & ESI1 & \\
\hline \multirow{3}{*}{27} & $\begin{array}{l}\text { Average preir- } \\
\text { radiation inner } \\
\text { sleeve diame- } \\
\text { ter for ent1re } \\
\text { element } \\
\text { (Inches) }\end{array}$ & $\begin{array}{l}\text { Sample random } \\
\text { error for } \\
\text { SI1 (inches) }\end{array}$ & $\begin{array}{l}\text { Combined random } \\
\text { error for SI1 } \\
\text { (inches) }\end{array}$ & \\
\hline
\end{tabular}

\begin{tabular}{|l|}
\hline \multicolumn{1}{|c|}{ Corments } \\
Only required if \\
IOPT(2) $=1$. \\
These data are \\
obtalned from STAT \\
results. \\
\end{tabular}

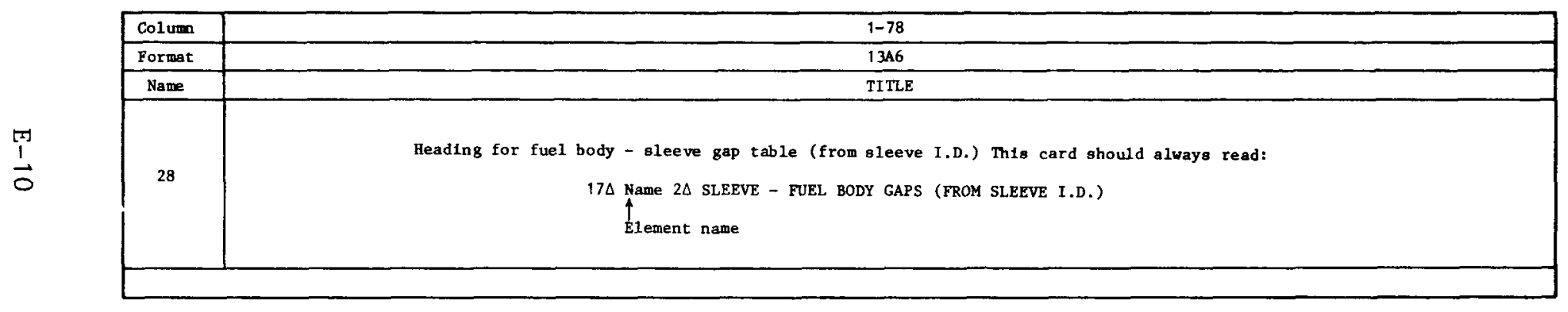

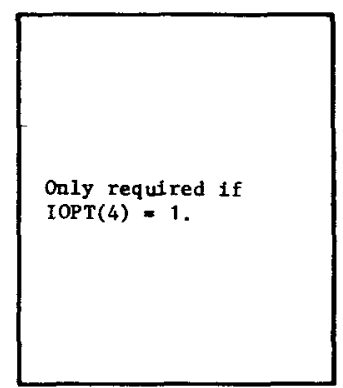

\begin{tabular}{|c|c|c|}
\hline Colum & $1-6$ & \\
\hline Format & I6 & \\
\hline Name & NPOS & \\
\hline 29 & $\begin{array}{l}\text { Number of sleeve } \\
\text { 1nner diameter } \\
\text { measurement } \\
\text { locations }\end{array}$ \\
\hline
\end{tabular}

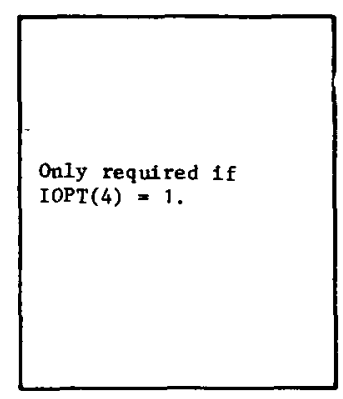




\begin{tabular}{|c|c|c|c|}
\hline Columi & $1-6$ & \multicolumn{1}{|c|}{$7-12$} & \\
\hline Format & I6 & \multicolumn{1}{|c|}{ I6 } & \\
\hline Hame & NS1(I) & NS2(I) & \\
\hline 30 & $\begin{array}{l}\text { Number of preir- } \\
\text { radiation sleeve } \\
\text { I.D. measure- } \\
\text { ments at measure- } \\
\text { ment location I }\end{array}$ & $\begin{array}{l}\text { Number of postir- } \\
\text { radiation sleeve } \\
\text { I.D. measurements } \\
\text { at measurement } \\
\text { location I }\end{array}$ & \\
\hline
\end{tabular}

\begin{tabular}{|l|}
\hline \multicolumn{1}{|c|}{ Comments } \\
Only required if \\
IOPT( 4$)=1$. \\
NPOS pairs of cards \\
30 and 31 are \\
required. \\
\end{tabular}

\begin{tabular}{|c|c|c|c|c|c|c|c|}
\hline Column & $1-10$ & $11-20$ & $21-30$ & $31-40$ & $41-50$ & $51-60$ & $61-70$ \\
\hline Format & E10.0 & $\begin{array}{l}\text { E10.0 } \\
\end{array}$ & E10.0 & E10.0 & E10.0 & E10.0 & E10.0 \\
\hline Name & SPOS (I) & S1(I) & SS1(I) & ES 1(I) & $\mathrm{s} 2(\mathrm{I})$ & ss2(I) & ES2(I) \\
\hline$\frac{1}{2}$ & $\begin{array}{l}\text { Core height of } \\
\text { measurement } \\
\text { location I } \\
\text { (inches) }\end{array}$ & $\begin{array}{l}\text { Preirradiation } \\
\text { sleeve inner } \\
\text { diameter at } \\
\text { measurement } \\
\text { location I } \\
\text { (inches) }\end{array}$ & $\begin{array}{l}\text { Sample random } \\
\text { error for S1 (I) } \\
\quad \text { (1nches) }\end{array}$ & $\begin{array}{l}\text { Combined random } \\
\text { error for } S 1 \text { (I) } \\
\text { (1nches) }\end{array}$ & $\begin{array}{l}\text { Postirradiation } \\
\text { sleeve Inner } \\
\text { diameter at meas- } \\
\text { urement location } \\
\text { I (Inches) }\end{array}$ & $\begin{array}{l}\text { Sample random } \\
\text { error for S2(I) } \\
\text { (Inches) }\end{array}$ & $\begin{array}{l}\text { Comblined random } \\
\text { error for } S 2(I) \\
\text { (Inches) }\end{array}$ \\
\hline
\end{tabular}

\begin{tabular}{|l|}
\hline \\
Only required if \\
IOPT $(4)=1$. \\
These cards are \\
Punched by the \\
STAT code. \\
\end{tabular}
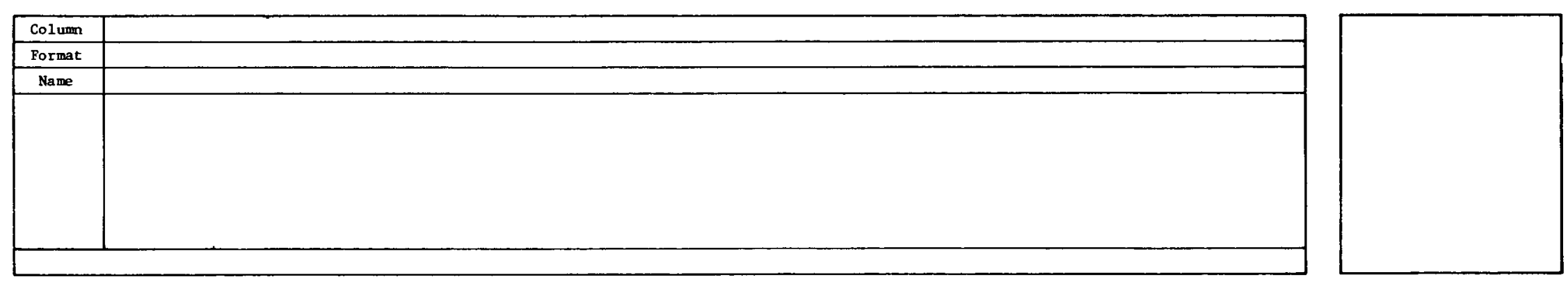
APPENDIX $F$

GAPS SAMPLE PROBLEM 
CONTROL CARDS FOR GAPS SAMPLE PRODALEM RUN

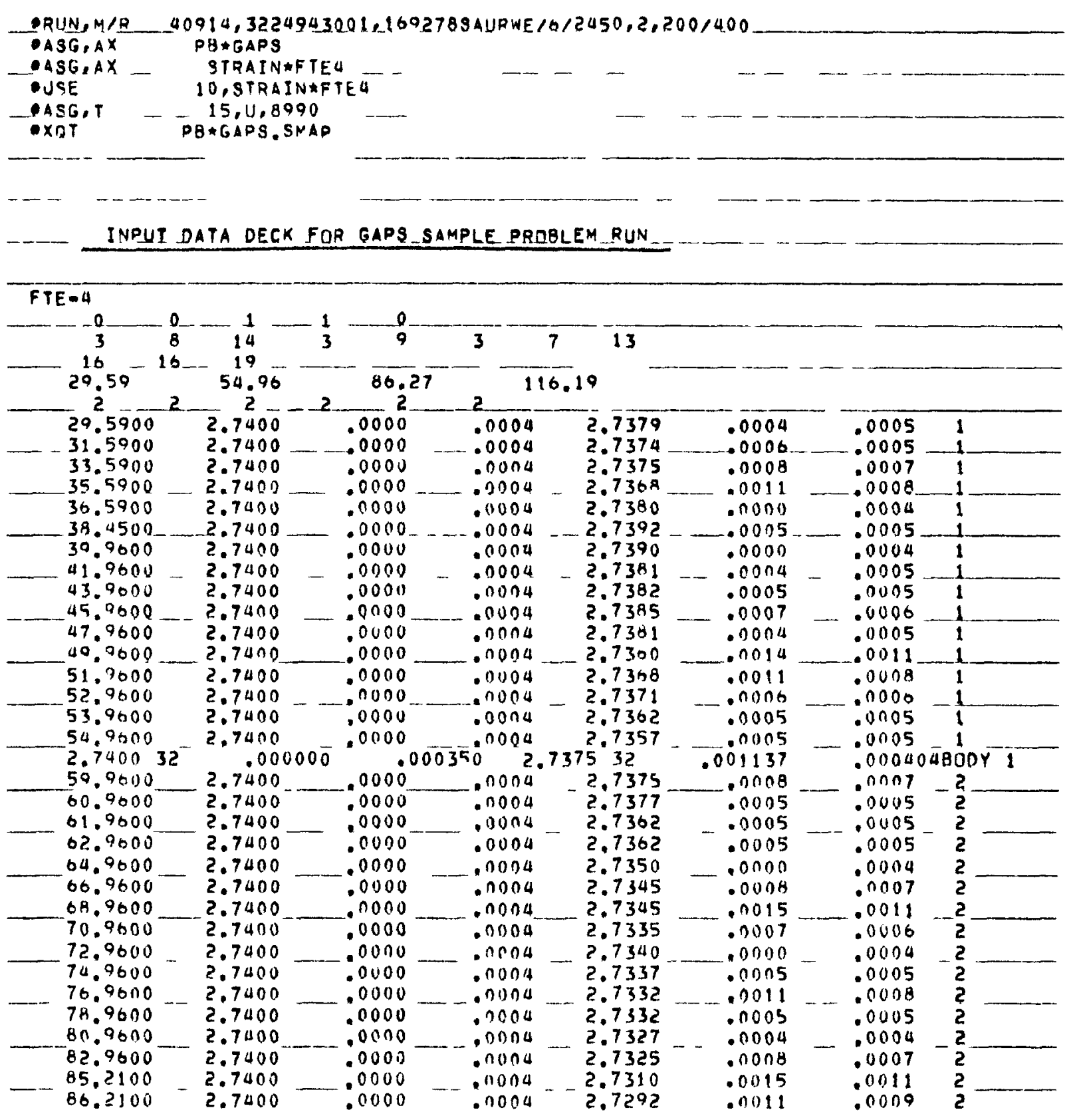




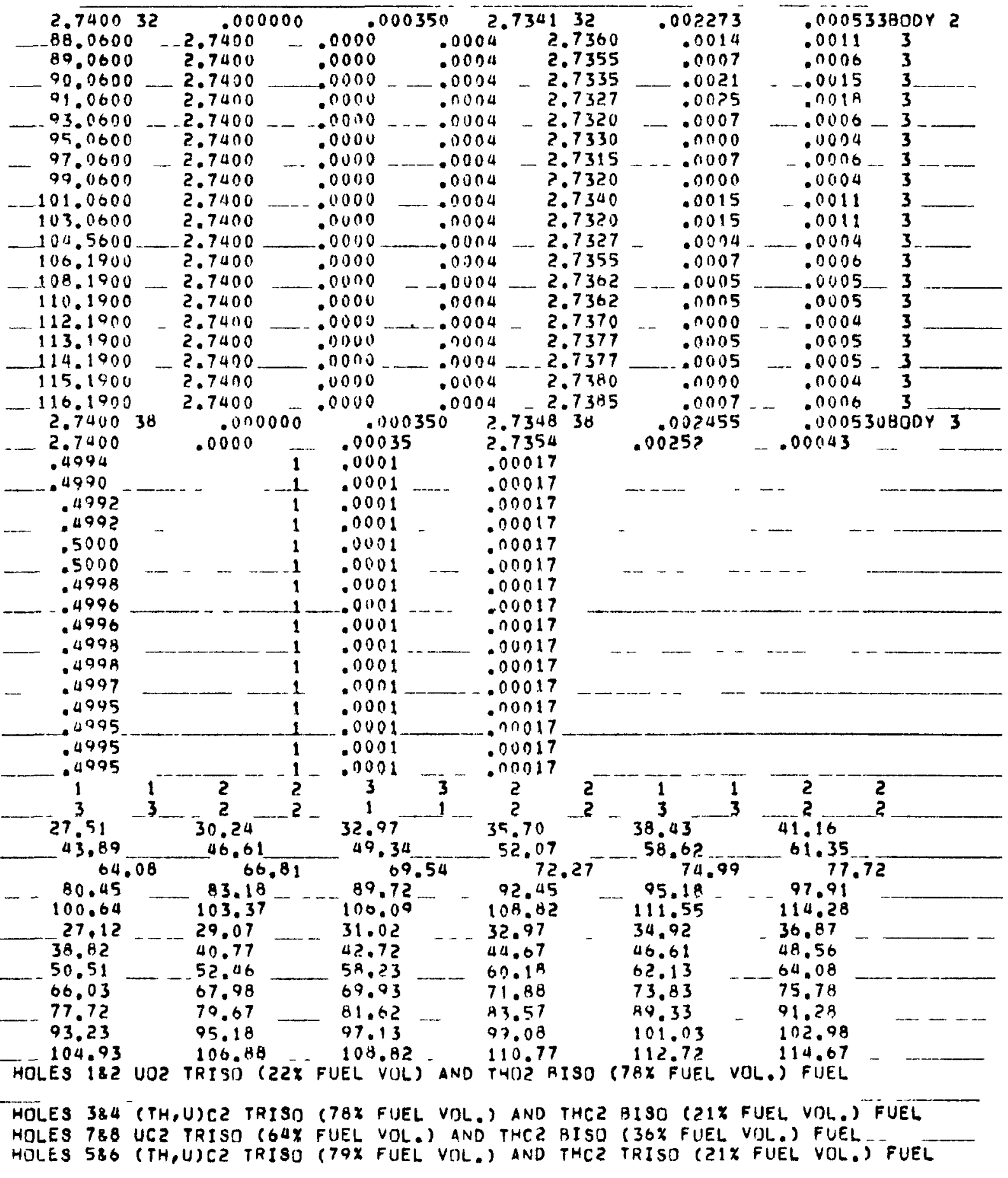




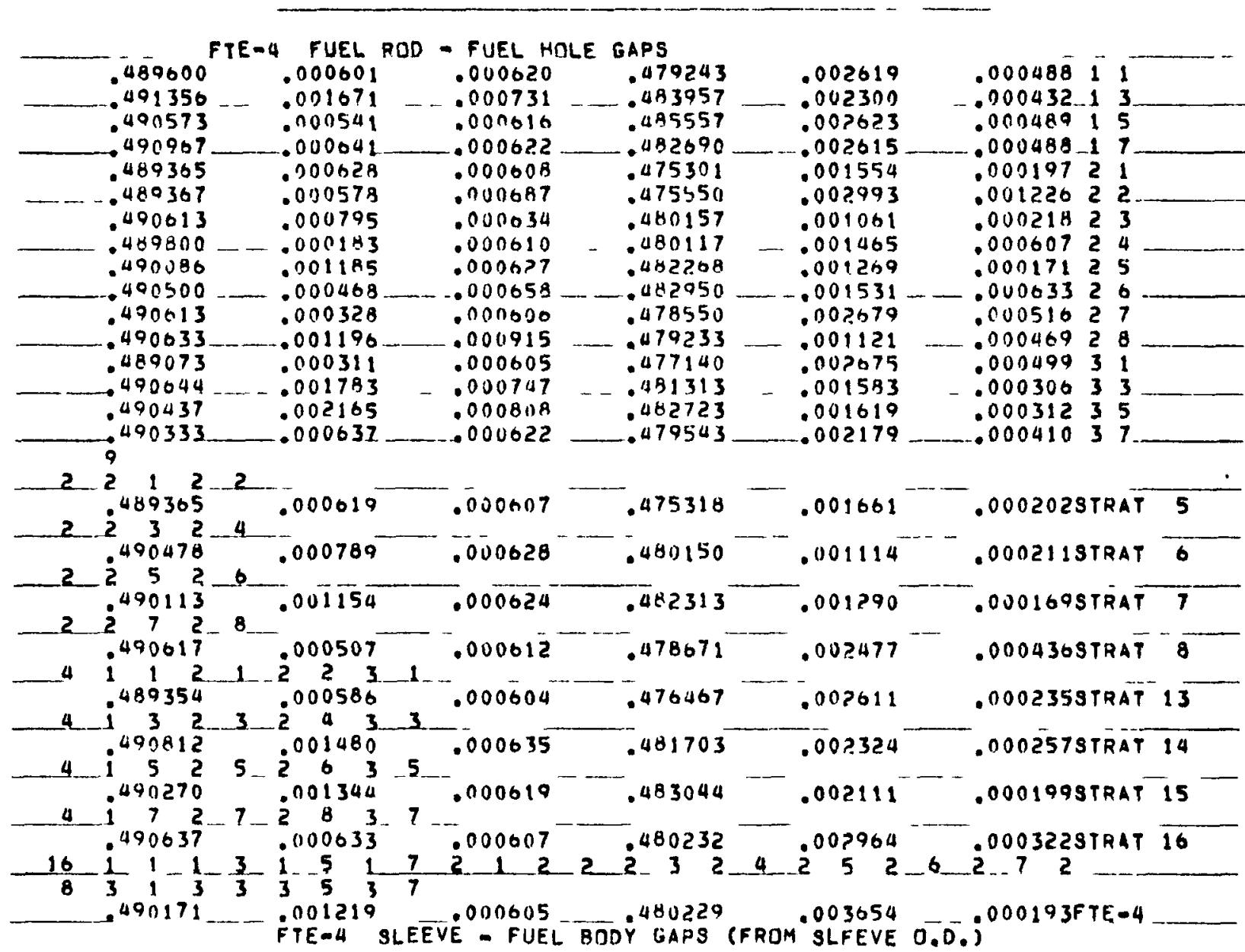

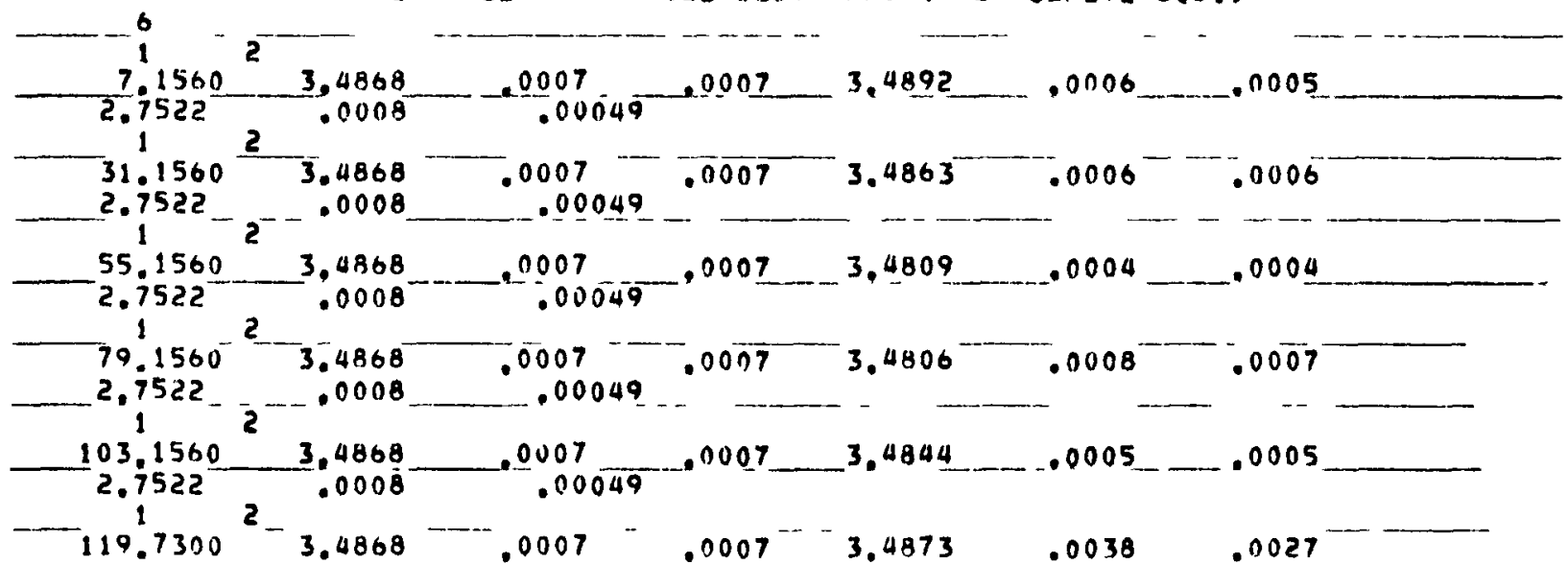




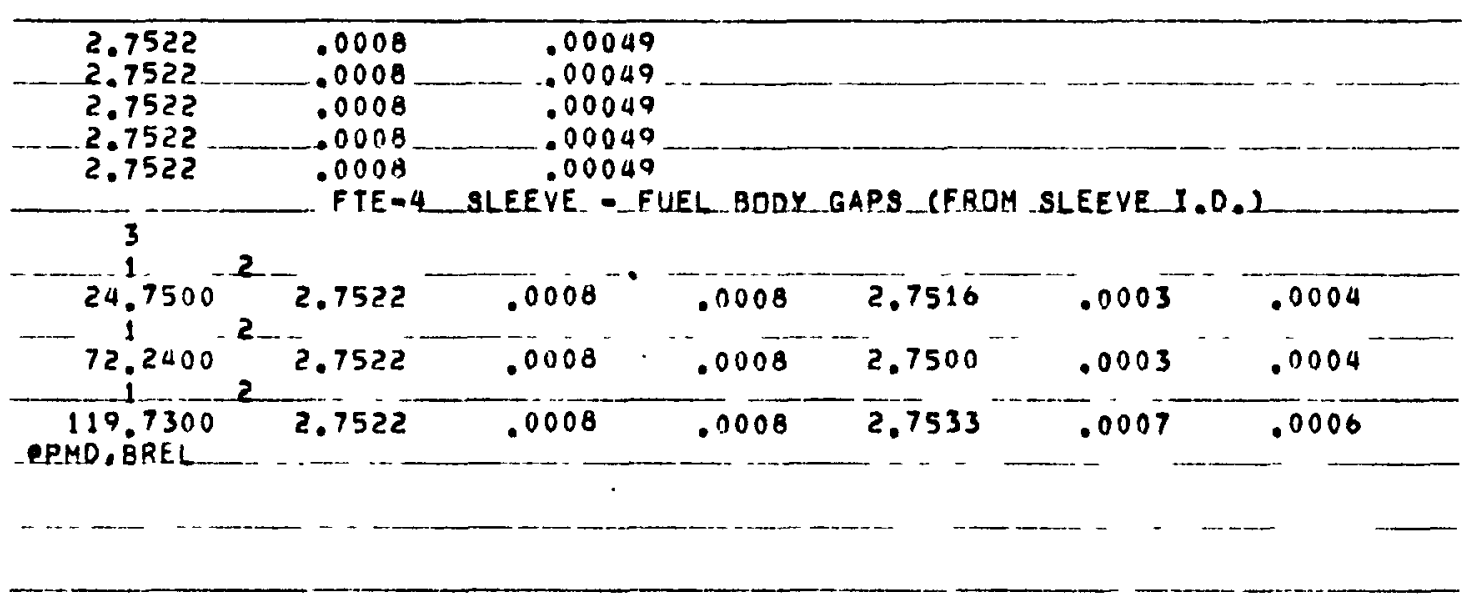

THE NUMBERS AND NOTATIONS APPEARING IN THE IDENTIFICATION FIELD (COLUMNS 73-80) OF THE ABOVE CARDS ARE PUNCHED BY STAT TO HELP IDENTIFY THE DATA CONTAINED ON THE CARDS. THESE NUMBERS AND NOTATIONS ARE NOT REQUIRED AS INPUT TO THE GAPS CODE. 


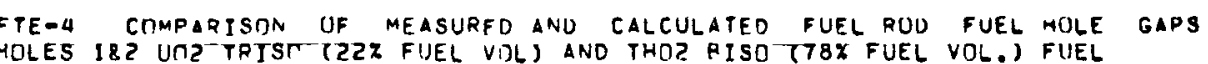

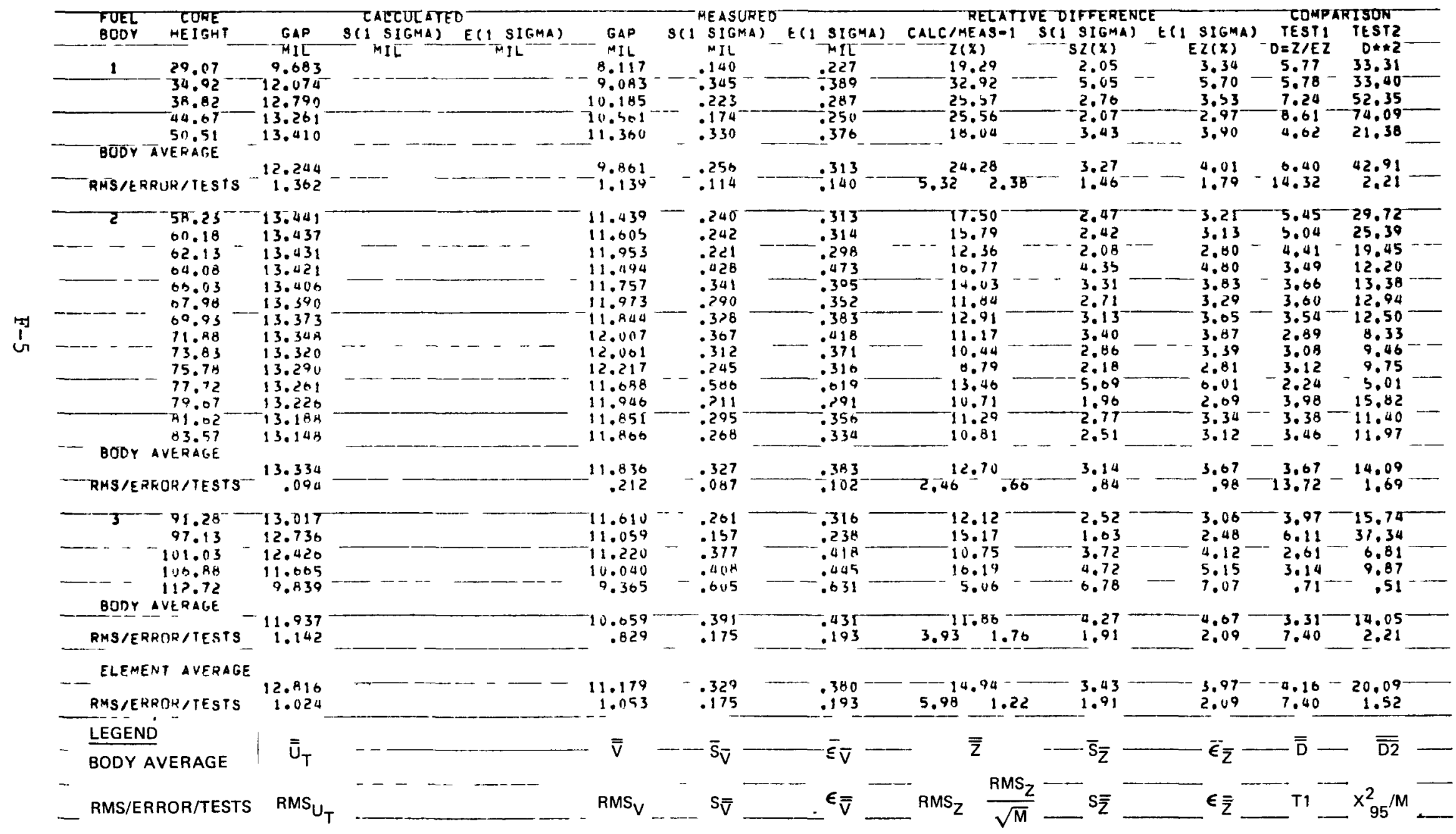

See Tables 4-1 and 3-2 for explanation of symbols 
FTE-4 CUMPARISINA TF MEASURFD AND CALCULATED FUEL RIJD FUFL HULE GAPS

HULES 384 (TF.UICZTRTSO T78\% FUFL VIL.) AND THEC RIST (21X FUEL VOL.) FUEL

HULES 788 UCE THISI) (OAX FUEL VOL.) AND THCZ BISO (30X FUEL VUL.) FUEL

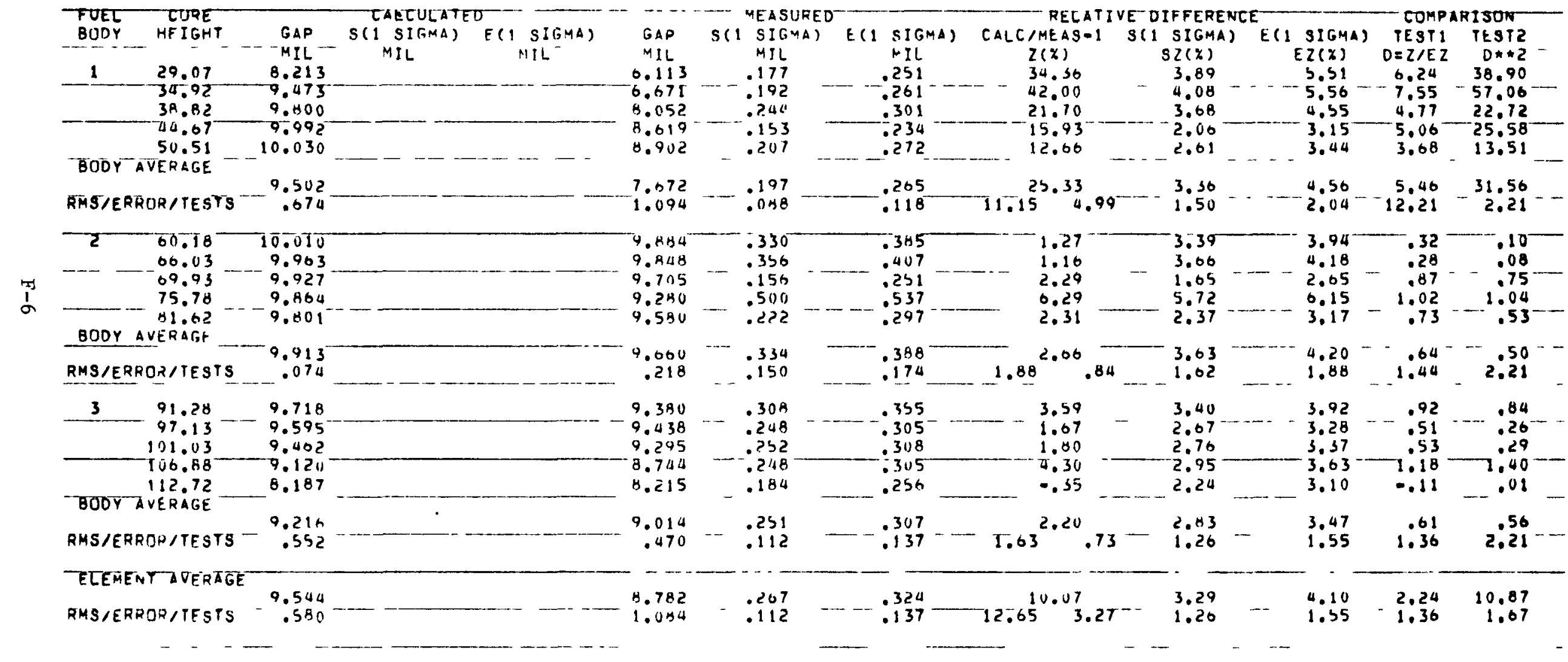


TE-4 COMPARISIN TIF MEASURED AND CALCULATED FUEL ROD FUEL HOLE GAPS

HOLES 586 (TH, (1)CZ TRISO $(79 \%$ FUEL VOL.) AND THC TRISO (2IX FUEL VOL.) FUEL

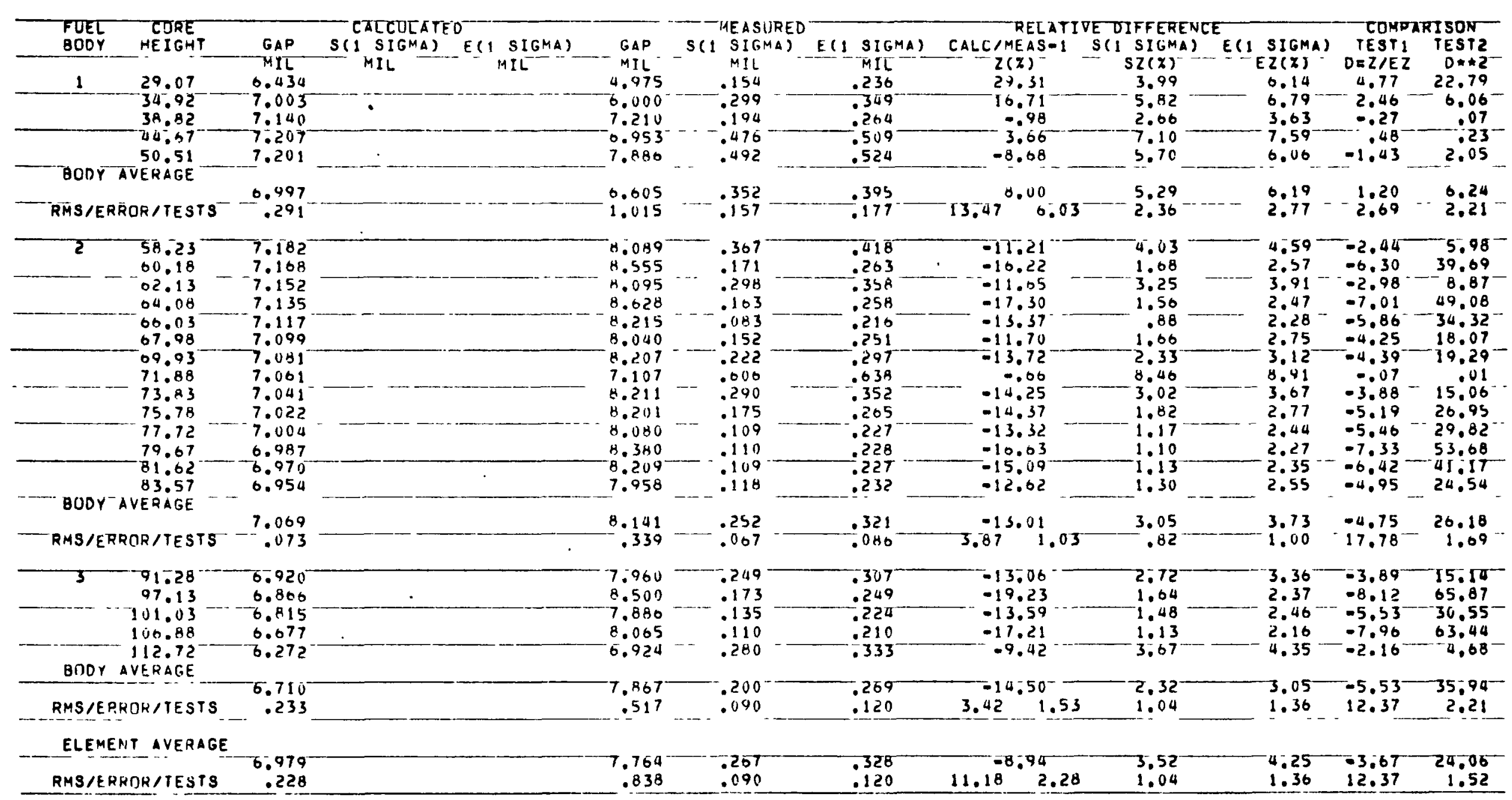


FTE-4 FUEL ROD - FUEL HOLE GAPS

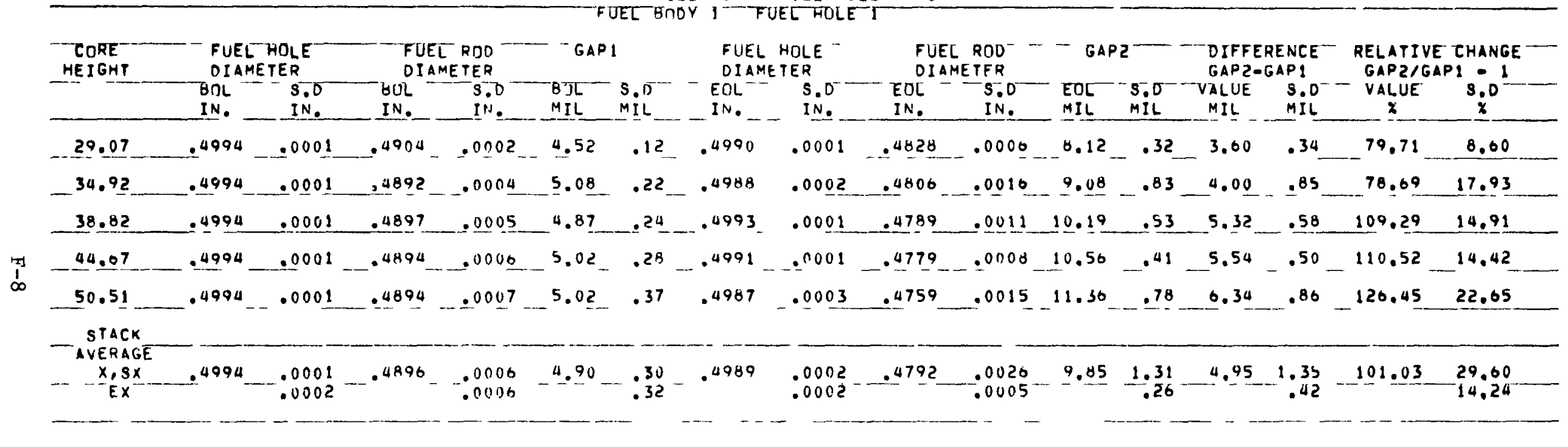

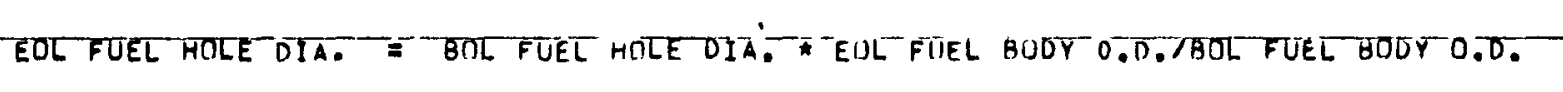




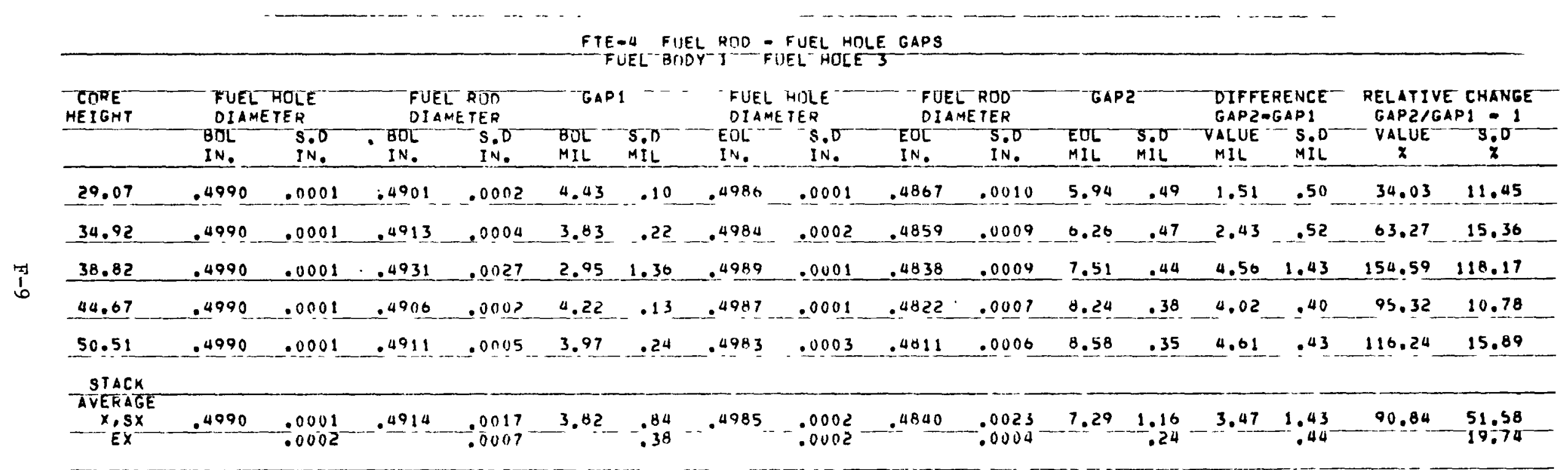

EOL FUEL HOLE OIA. = BOL FUEL RILE DIA. * EOL FUEL BODY 0.0.78OL FUEL BODY 0.0. 
FTE-4 FUEL PUD - FUEL HOLE GAPS

FUEL BNDY T FUEL GOLE 5

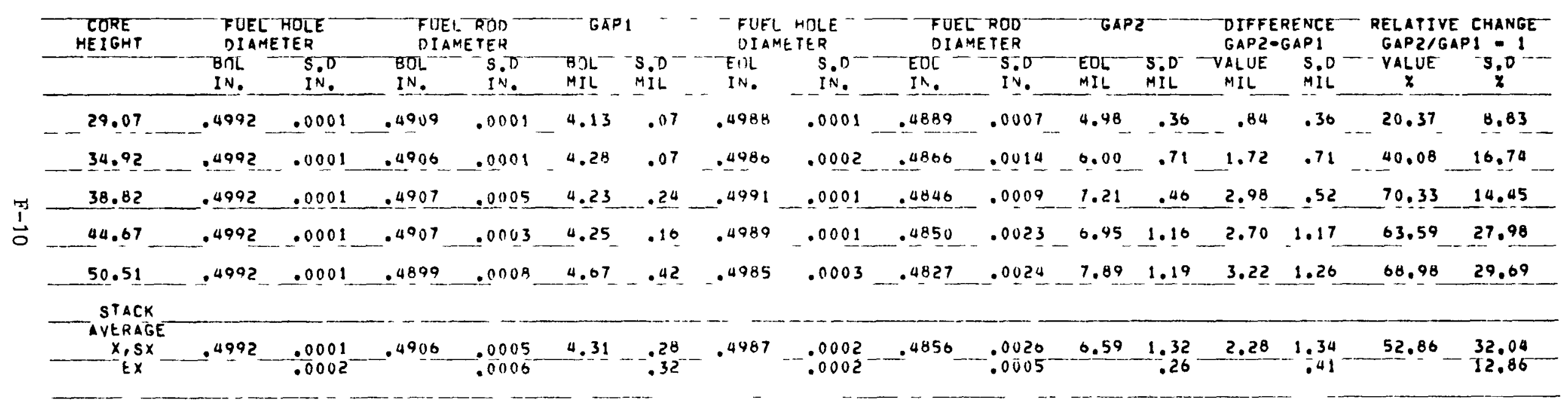

EOL FUEL HOLE DIA. = BNL FUEL HITE DIA. * EOL FUEL BODY 0.0.7BOL FUEL BUDYD.D. 
FTE-4 FUEL RUD - FUEL HDLE GAPS

FUEL BÕDY I FUEL HOLE

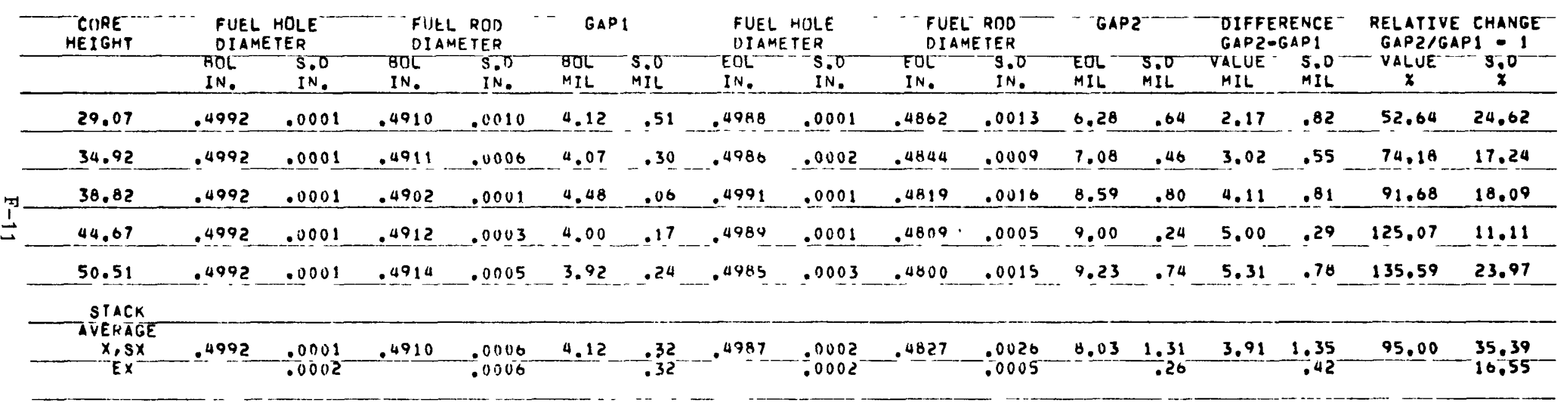

EOL FUEL ROLE DI.. $=$ BUL FUEL FUTE DIA. EOL FUEL BODY $0.0 .180 L$ FUEL BODY O.D. 
FTE-4 FUEL RUD - FUEL HOLE GAPS

FUEL EIOSY 2 FUEL HOLE I

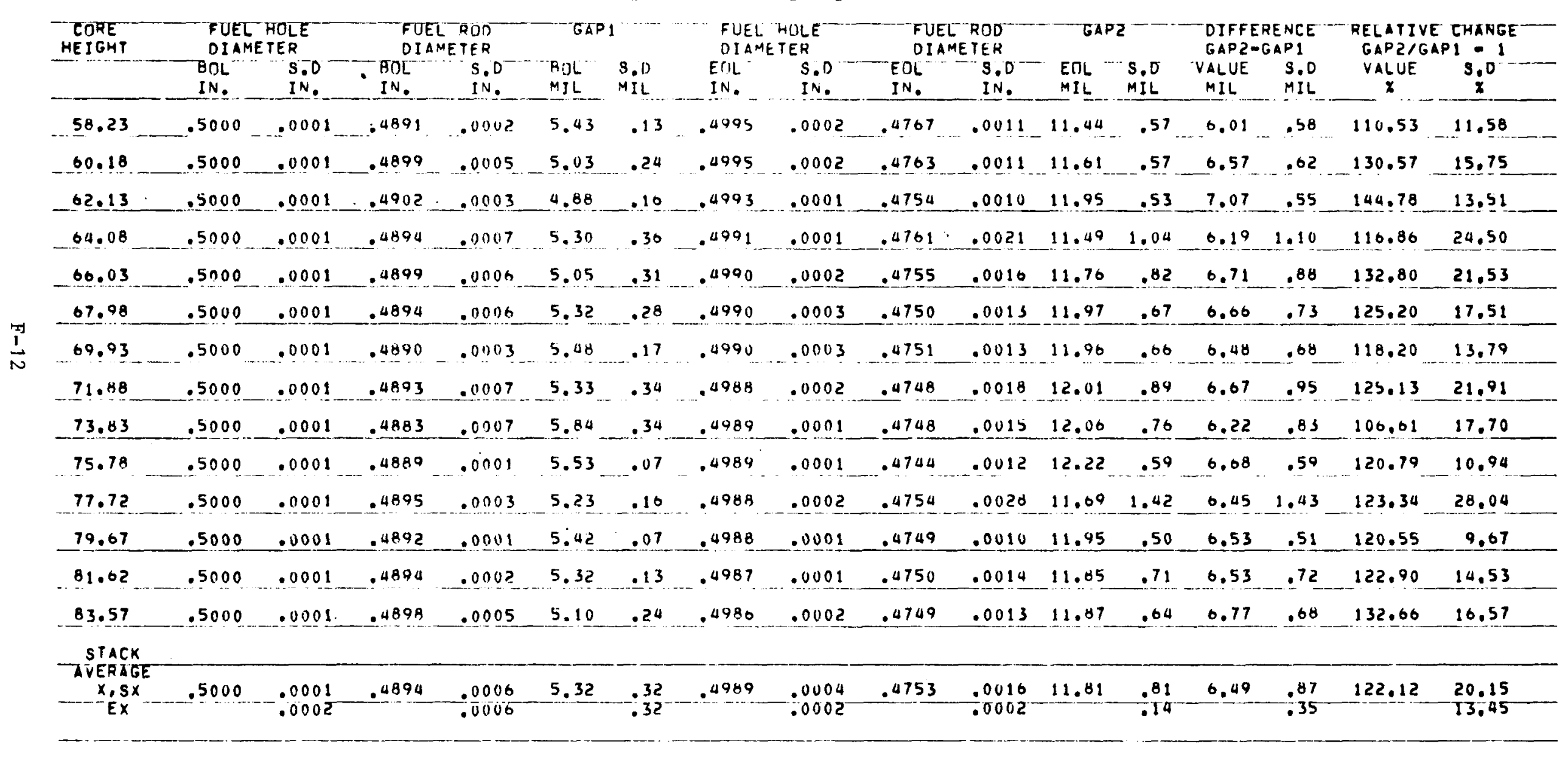

EOL FUEL HOLE OTA. = BUL FUEL ARLE DTA. ^-EOL FUEL BODY 0.0.7BUL FUEL BDOY O.0. 


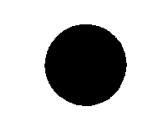

FTE-4 FUEL RUD - FUEL HOLE GAPS

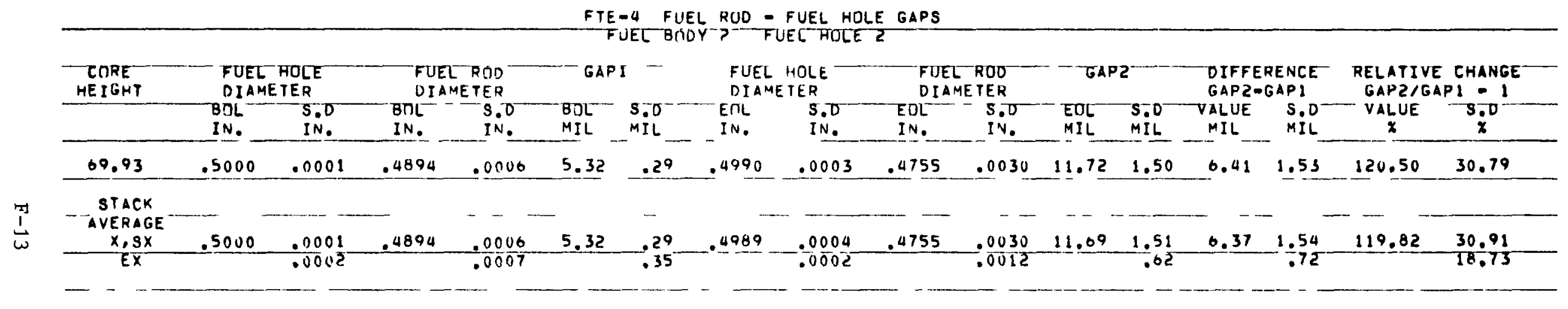

EOL FUEL HOLE DIA. $=$ BOL FUEL HULE OIA. * EOL FUEL B̄UDY 0.D.TBOL FUEL BODY O.0. 
FTE-4 FUEL RUD - FUEL HOLE GAPS

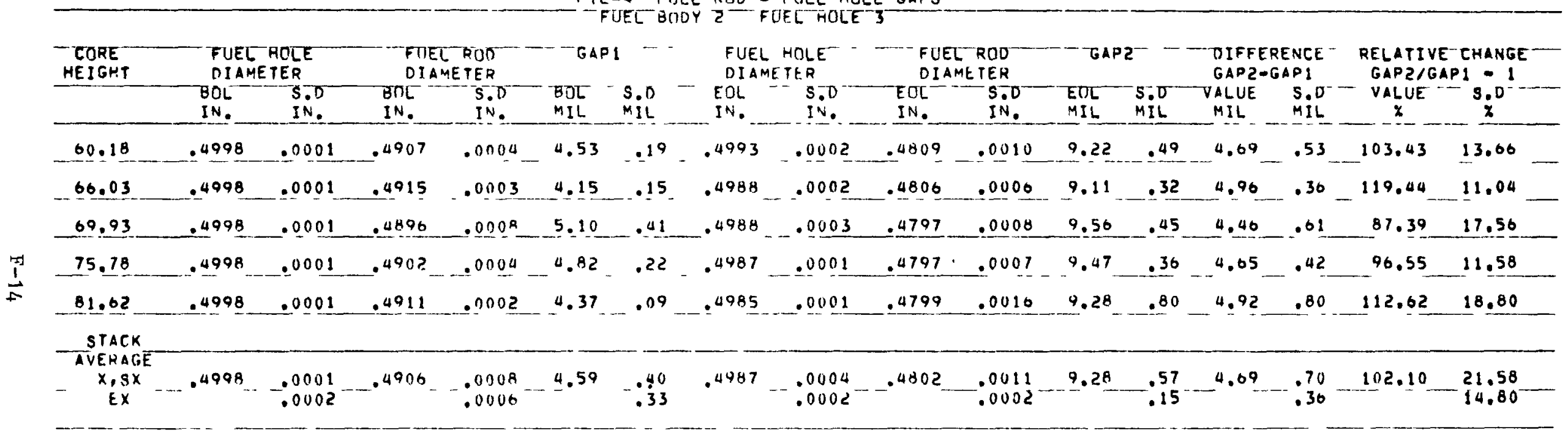

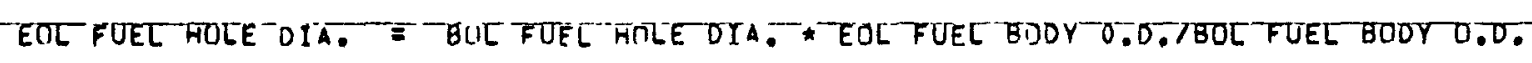


FTE-4 FUEL ROD - FUEL HOLE GAPS

\begin{tabular}{|c|c|c|c|c|c|c|c|c|c|c|c|c|c|c|c|}
\hline \multirow[t]{2}{*}{$\begin{array}{c}\text { CORE } \\
\text { MEIGHI }\end{array}$} & \multicolumn{2}{|c|}{$\begin{array}{l}\text { FUEL HOLE } \\
\text { OIAMETER }\end{array}$} & \multicolumn{2}{|c|}{$\begin{array}{l}\text { FUEL ROD } \\
\text { DIAMETER }\end{array}$} & \multirow{2}{*}{$\begin{array}{l}\text { GAPI } \\
\text { BOL - S.D } \\
M I L\end{array}$} & \multicolumn{2}{|c|}{$\begin{array}{l}\text { FUEL HULE } \\
\text { OIAMETER }\end{array}$} & \multicolumn{2}{|c|}{$\begin{array}{l}\text { FUEL RTIO } \\
\text { OIAMETER }\end{array}$} & \multicolumn{2}{|c|}{ GAPE } & \multicolumn{2}{|c|}{$\begin{array}{l}\text { DIFFERENCE } \\
\text { GAPZ-GAPI }\end{array}$} & \multicolumn{2}{|c|}{$\begin{array}{l}\text { RELATIVE CHANGE } \\
\text { GAPZ/GAPI }=1\end{array}$} \\
\hline & $\begin{array}{l}\text { BOLL } \\
\text { IN. }\end{array}$ & $\begin{array}{l}\text { S.D } \\
\text { IN. }\end{array}$ & $\begin{array}{l}80 \mathrm{~L} \\
\mathrm{IN} . \\
\end{array}$ & $\begin{array}{l}S .0 \\
I N .\end{array}$ & & $\begin{array}{l}E O L \\
I N .\end{array}$ & $\begin{array}{l}S .0 \\
I N .\end{array}$ & $\begin{array}{l}\text { EUL } \\
\text { IN. }\end{array}$ & $\begin{array}{l}S .0 \\
I N .\end{array}$ & $\begin{array}{l}E \sigma L^{-} \\
\text {MIL }\end{array}$ & $\begin{array}{l}\text { S.D } \\
M I L\end{array}$ & $\begin{array}{l}\text { VALUE } \\
\text { MIL }\end{array}$ & $\begin{array}{l}\text { S.D } \\
M I L\end{array}$ & $\begin{array}{c}\text { VALUE } \\
\times\end{array}$ & $\begin{array}{r}3 \cdot 0 \\
x \\
\end{array}$ \\
\hline 69.93 & .4996 & .0001 & .4898 & .0002 & 4.90 & .4986 & .0003 & .4801 & .0015 & 9.24 & .75 & 4.34 & .75 & 88.58 & 15.77 \\
\hline STACK & & & & & & & & & & & & & & & \\
\hline $\begin{array}{c}\text { AVERAGE } \\
X, S X\end{array}$ & .4996 & .0001 & .4898 & .0002 & 4.90 & .4985 & .00004 & .4801 & $\begin{array}{l}.0015 \\
.0006\end{array}$ & 9.20 & $\begin{array}{l}.76 \\
.32\end{array}$ & 4.30 & $\begin{array}{r}.77 \\
.45\end{array}$ & 87.83 & $\begin{array}{l}16.07 \\
13.79\end{array}$ \\
\hline
\end{tabular}

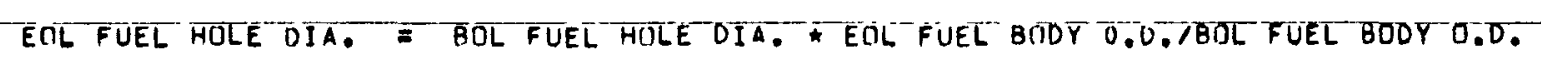


FTE-4 FUEL RUD - FUEL HOLE GAPS

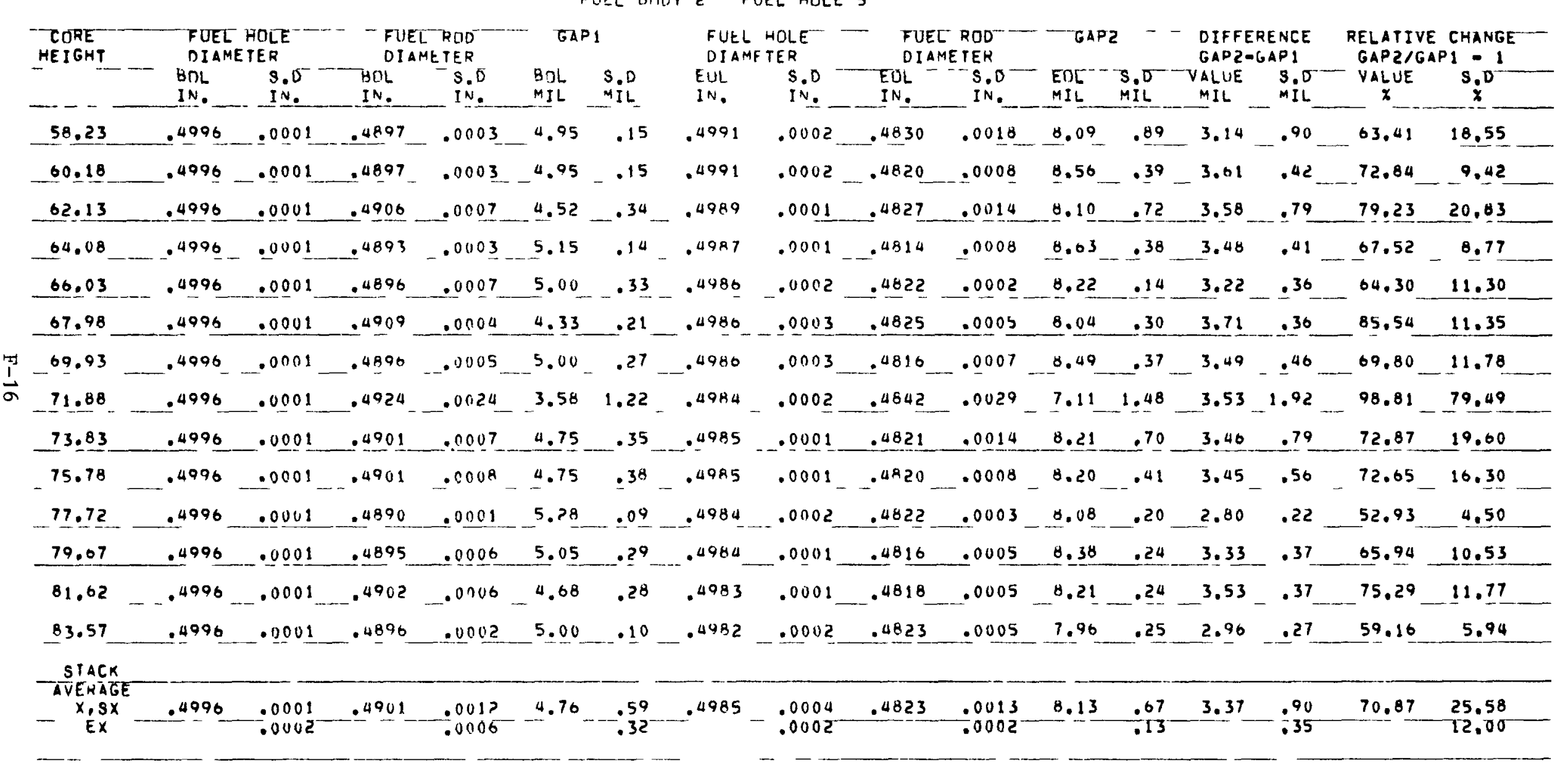

EOL FUEL HOLE DIA. = BOL FUEL AILE DIA. * EOL FUEL ROOY 0.0.7ROL FUEL BOOY D.D. 
FTE-4 FUEL RUD - FUEL HDLE GAPS

FUEC BUOY 2 PDEL HOLE 6

\begin{tabular}{|c|c|c|c|c|c|c|c|c|c|c|c|c|c|c|c|c|}
\hline \multirow[t]{2}{*}{$\begin{array}{l}\text { CURE } \\
\text { MEIGHT }\end{array}$} & \multicolumn{2}{|c|}{$\begin{array}{l}\text { FDEL HOLE } \\
\text { OIAMETER }\end{array}$} & \multicolumn{2}{|c|}{$\begin{array}{l}\text { FUEL ROD } \\
\text { DIAMETEQ }\end{array}$} & \multicolumn{2}{|c|}{ GAPI- } & \multicolumn{2}{|c|}{$\begin{array}{l}\text { FUEL HOLE- } \\
\text { OIAMETER }\end{array}$} & \multicolumn{2}{|c|}{$\begin{array}{l}\text { FUEL ROD } \\
\text { DIAMETER }\end{array}$} & \multicolumn{2}{|c|}{ GAPE } & \multicolumn{2}{|c|}{$\begin{array}{l}\text { DIFFERENCE - } \\
\text { GAPZ-GAPI }\end{array}$} & \multicolumn{2}{|c|}{$\begin{array}{l}\text { RELATIVE CHANGE } \\
\text { GAP2/GAPI }=1\end{array}$} \\
\hline & $\begin{array}{l}\text { BN. } \\
\text { IN. }\end{array}$ & $\begin{array}{l}5.0 \\
\text { IN. }\end{array}$ & $\begin{array}{l}\text { BOL } \\
I N .\end{array}$ & $\begin{array}{l}\text { s.o } \\
\text { in. }\end{array}$ & $\begin{array}{l}B D L \\
M I L\end{array}$ & $\begin{array}{l}\text { S.O } \\
\text { MIL }\end{array}$ & $\begin{array}{l}\text { EOL } \\
\text { IN. }\end{array}$ & $\begin{array}{l}=5.0 \\
\text { sin. }\end{array}$ & $\begin{array}{l}E O L- \\
I N .\end{array}$ & $\begin{array}{l}5.0 \\
\text { iN. }\end{array}$ & $\begin{array}{l}\text { EOL } \\
\text { MIL }\end{array}$ & SII & $\begin{array}{l}\text { VALUE } \\
\text { MIL }\end{array}$ & $\begin{array}{l}\text { S:D } \\
\text { MIL }\end{array}$ & $\begin{array}{c}\text { VALUE } \\
x\end{array}$ & $\begin{array}{c}3.0 \\
x\end{array}$ \\
\hline 69.93 & .4998 & .0001 & .4905 & .0005 & 4.65 & .24 & .4988 & .0003 & .4829 & .0015 & 1.92 & .78 & 3.27 & .81 & 70.40 & 18.91 \\
\hline STACK & & & & & & & & & & & & & & & & \\
\hline$\frac{x_{0}, 5 x}{E x}$ & .4998 & $\frac{.0001}{.0002}$ & .4905 & .0005 & 4.65 & $\begin{aligned} .24 \\
-.34\end{aligned}$ & 4987 & .0004 & .4829 & .0015 & 1.89 & $\begin{array}{r}.79 \\
.33\end{array}$ & 3.24 & $\begin{array}{l}.83 \\
.98 \\
.48\end{array}$ & 69.61 & -19.19 \\
\hline
\end{tabular}

EOL FUEL HOLE DIA. = BOLFUEL HNLEE OTA. *EUL FUEL BODY $0.0 . / B O L$ FUEL BOOY O.D. 
FTE-4 FUEL RUD - FUEL HOLE GAPS

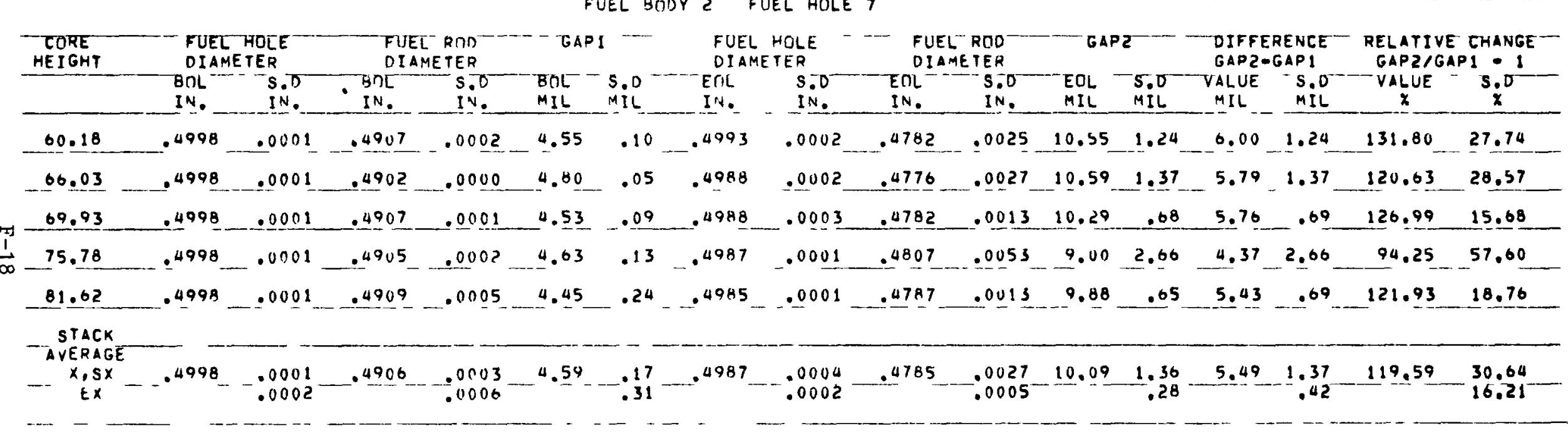

EOL FUEL HOLE DIA. = BOL FUEL FULE OIA. EOL FUEL BUDY 0.0 .7 . FOL FUEL BODY O.0. 
FTE-4 FUEL ROD - FUEL HOLE GAPS

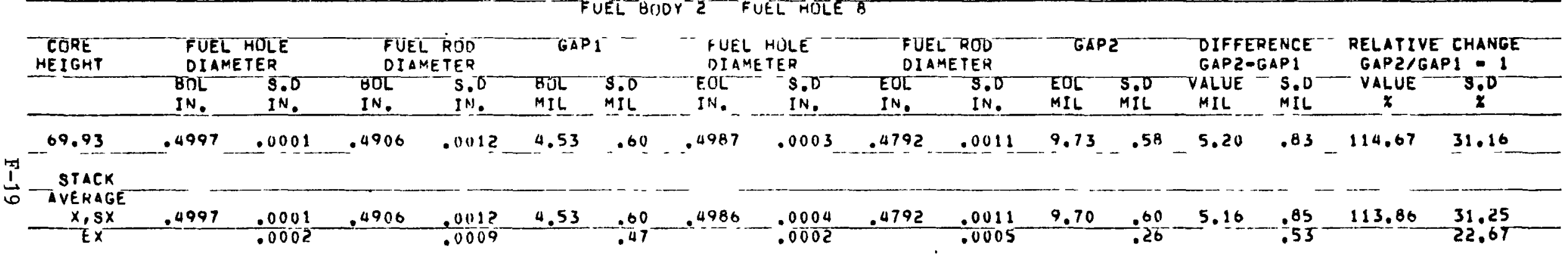

EOL FUEL HOLE DIA. = BUL FUEL HOLE DIA. * EOL FUEL BOOY $0.0 .7 B O L$ FUEL BOOY 0.0. 
FTE-4 FUEL ROD - FUEL HOLE GAPS

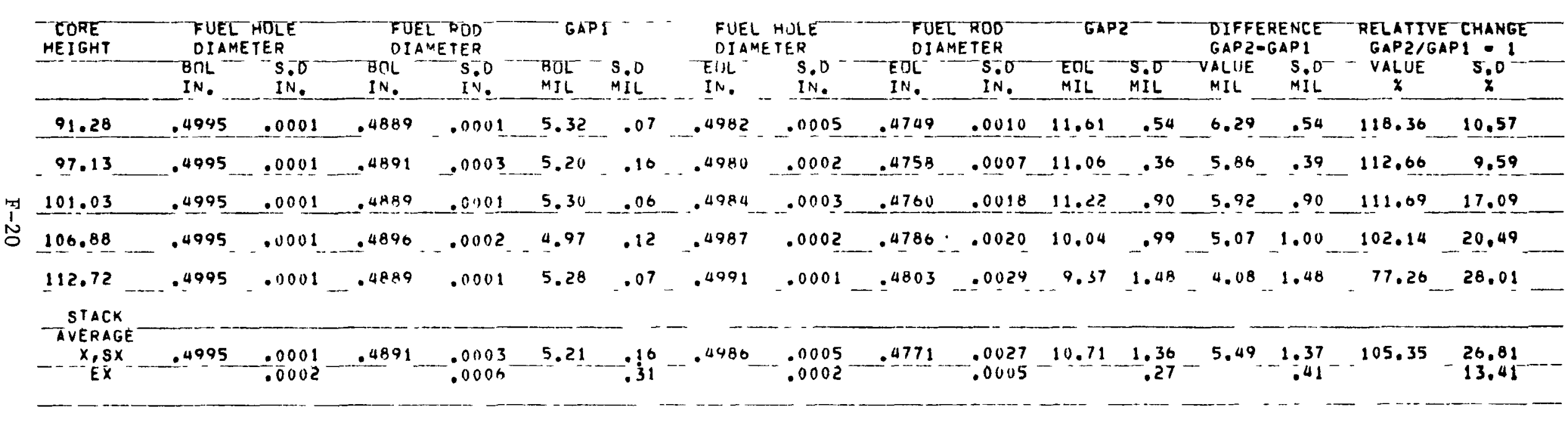

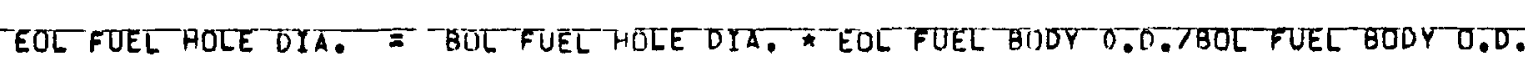




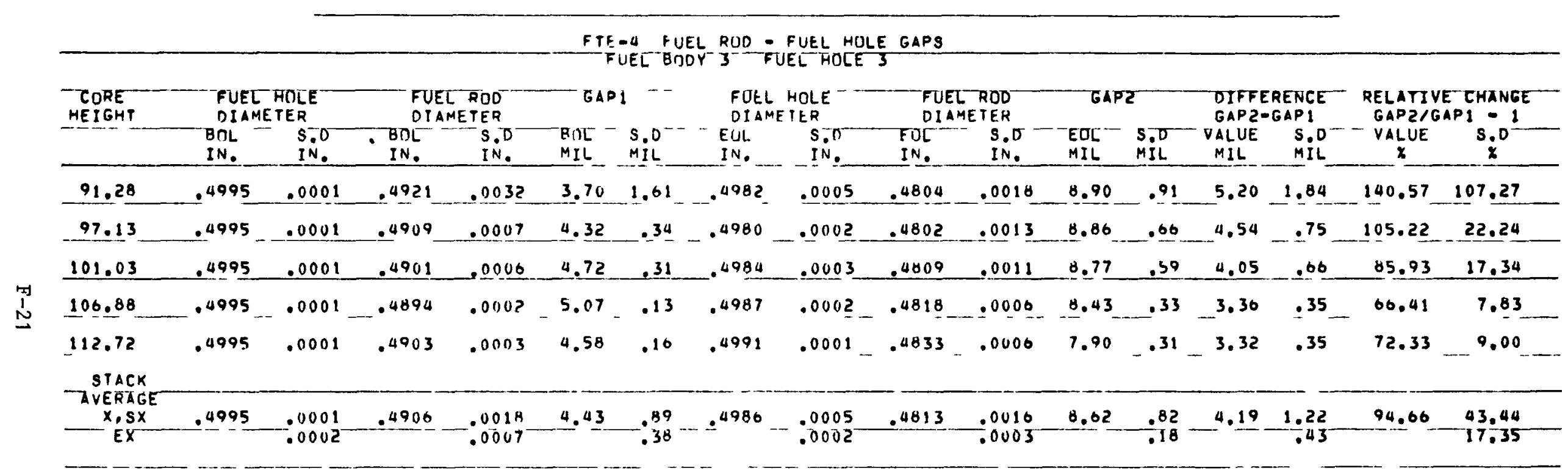

EOL FUEC HOLE OIA. " BUL FUEL HILE DSA. * EOL FUEL BOOY $0.0 .780 L$ FUEL BODY 0.0 . 
FTE- 4 FUEL RUD - FUEL HOLE GAPS

FUEL BIOY 3 FUEL HILLE 5

\begin{tabular}{|c|c|c|c|c|c|c|c|c|c|c|c|c|c|c|c|c|}
\hline \multirow[t]{2}{*}{$\begin{array}{l}\text { CORE } \\
\text { HEIGHT }\end{array}$} & \multicolumn{2}{|c|}{$\begin{array}{l}\text { FUEL HOLE } \\
\text { DI AME TER }\end{array}$} & \multicolumn{2}{|c|}{$\begin{array}{l}\text { FUEL ROD } \\
\text { DIAMETER }\end{array}$} & \multicolumn{2}{|c|}{ GAP I } & \multicolumn{2}{|c|}{$\begin{array}{l}\text { FUEL HOLE } \\
\text { DIAMETER }\end{array}$} & \multicolumn{2}{|c|}{$\begin{array}{l}\text { FUEL ROD } \\
\text { DI AME TER }\end{array}$} & \multicolumn{2}{|c|}{ GAP2 } & \multicolumn{2}{|c|}{$\begin{array}{l}\text { DIFFERENCE } \\
\text { GAPZ-GAPI }\end{array}$} & \multicolumn{2}{|c|}{$\begin{array}{l}\text { RELATIVE CHANGE } \\
\text { GAP } 2 / G A P 1=1\end{array}$} \\
\hline & $\begin{array}{l}B O L \\
\text { IN. }\end{array}$ & $\begin{array}{l}\text { S.0 } \\
\text { IN. }\end{array}$ & $\begin{array}{l}\text { BDL } \\
\text { IN. }\end{array}$ & $\begin{array}{l}S . D^{-} \\
\text {IN. }\end{array}$ & MIL & $\begin{array}{l}S: D^{-} \\
\text {MIL }\end{array}$ & $\begin{array}{l}\text { EDL } \\
\text { IN. }\end{array}$ & $\begin{array}{l}3.0 \\
I N .\end{array}$ & $\begin{array}{l}\text { EOL } \\
\text { IN. }\end{array}$ & $\begin{array}{l}\text { S.D } \\
\text { IN. }\end{array}$ & $\begin{array}{l}\text { EUL } \\
\text { MIL }\end{array}$ & $\begin{array}{l}5.0 \\
\text { MIL }\end{array}$ & $\begin{array}{l}\text { VALUE } \\
\text { MIL }\end{array}$ & $\begin{array}{l}\text { S.D } \\
M I L\end{array}$ & $\begin{array}{c}\text { VALUE } \\
X\end{array}$ & 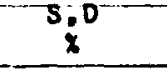 \\
\hline 91.28 & .4995 & .0001 & .4898 & .0010 & 4.83 & .52 & .4982 & .0005 & .4822 & .0009 & 7.96 & .51 & 3.13 & .73 & 64.68 & 20.71 \\
\hline 97.13 & .4995 & .0001 & .4894 & .0008 & 5.05 & .39 & .4980 & .0002 & .4809 & .0008 & 8.50 & .40 & 3.45 & .56 & 68.32 & 15.32 \\
\hline 101.03 & .4995 & .0001 & .4899 & .0004 & 4.82 & .19 & $\therefore \triangle A B \triangle$ & .0003 & .4826 & .0004 & 7.89 & .24 & 3.07 & .31 & 63.73 & 8.06 \\
\hline 106.68 & .4995 & .0001 & .4894 & .0002 & 5.05 & .12 & .4987 & .0002 & .4825 & .0004 & 8.06 & .23 & 3.01 & .26 & 59.70 & 5,96 \\
\hline 112.72 & .4995 & .0001 & .4929 & .0034 & 3.31 & 1.69 & .4991 & .0001 & .4852 & .0013 & 6.92 & .67 & 3.61 & 1.82 & 109.02 & 108.57 \\
\hline STACK & & & & & & & & & & & & & & & & \\
\hline $\mathrm{Ex}_{\mathrm{Ex}}$ & .4995 & $\begin{array}{l}.0001 \\
.0002\end{array}$ & .4904 & $\begin{array}{l}.0022 \\
.0008\end{array}$ & 4.53 & $\begin{array}{r}1.08 \\
.41\end{array}$ & .4986 & $\begin{array}{l}.0005 \\
.0002\end{array}$ & .4827 & $\begin{array}{r}.0016 \\
-00003\end{array}$ & 7.91 & $\begin{array}{r}.84 \\
.19\end{array}$ & 3.38 & $\begin{array}{r}1.37 \\
.45\end{array}$ & 74.66 & $\begin{array}{l}45.71 \\
16.44\end{array}$ \\
\hline
\end{tabular}

EOL FUEL HOLE OTA. $=$ BOL FUEL HOLE OIA. \$ EOL FUEL BOOY $0.0 .180 L$ FUEL BOOY 0.0. 
FTE-4 FUEL RUD - FUEL HOLE GAPS

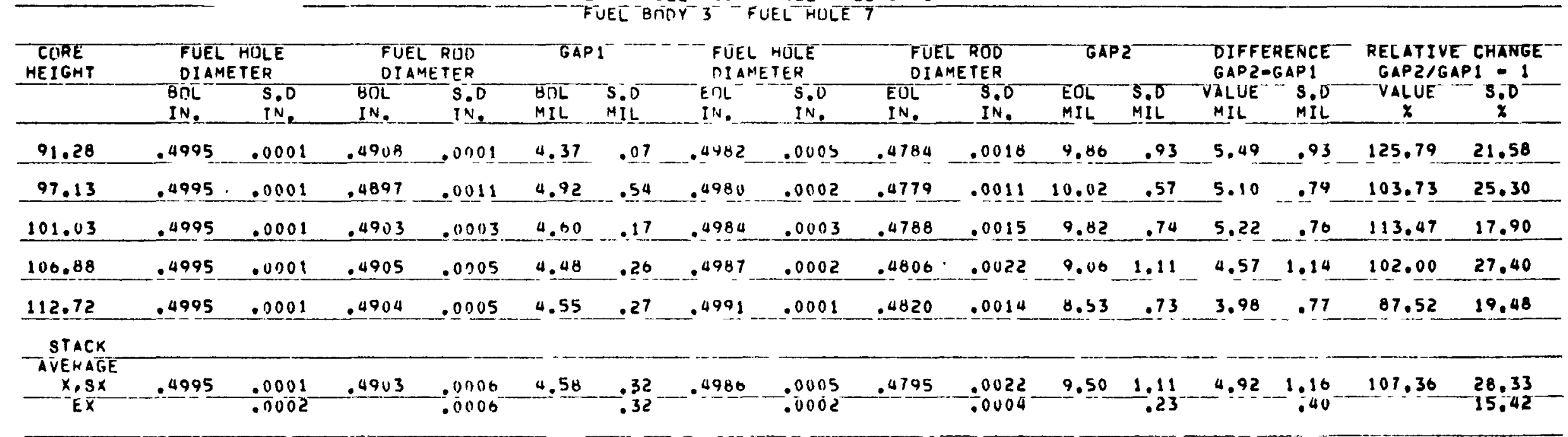

EOL FUEL HOLE DIA. = BOL FUEL HOLE DTA. „ EUL FUEL BOOY 0.0.18OL FUEL BOOY O.D. 
FTE-A FUEL ROD - FUEL HOLE GAPS

FUEL HOLE
DIAMETER

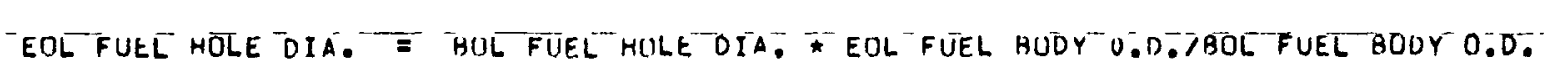


FTE-4 FUEL RHD - FUEL HOLE GAPS

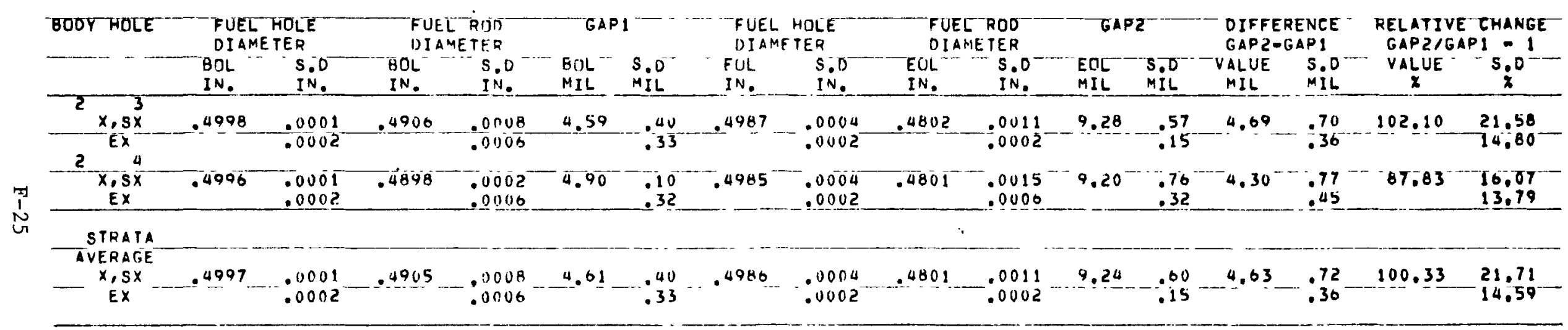

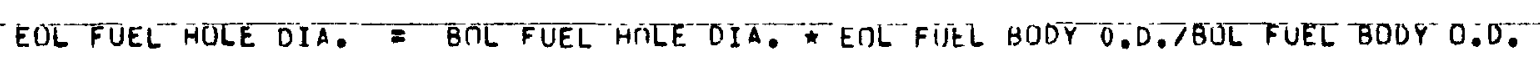


FTE=- FUEL RUD - FIJEL HOLE GAPS

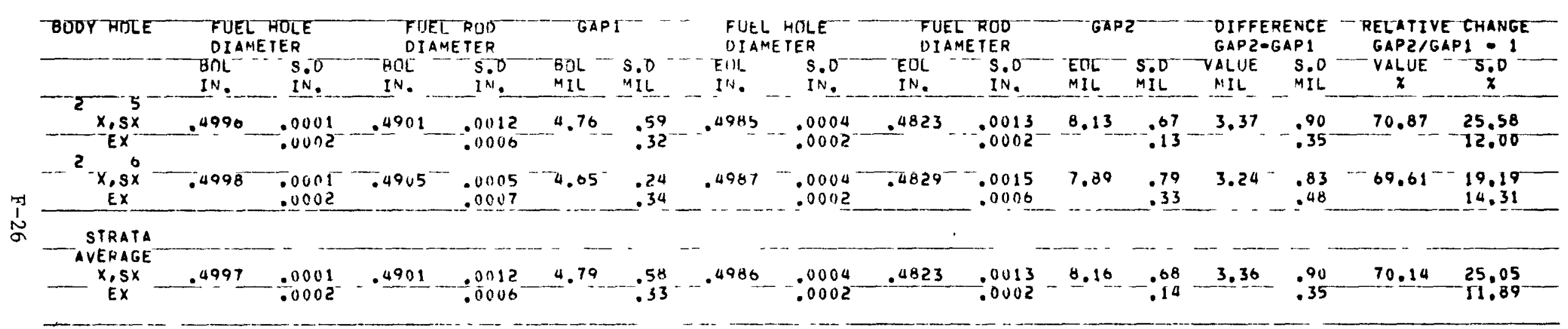

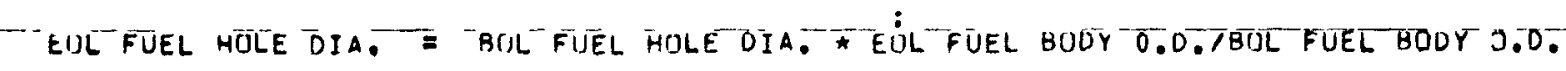




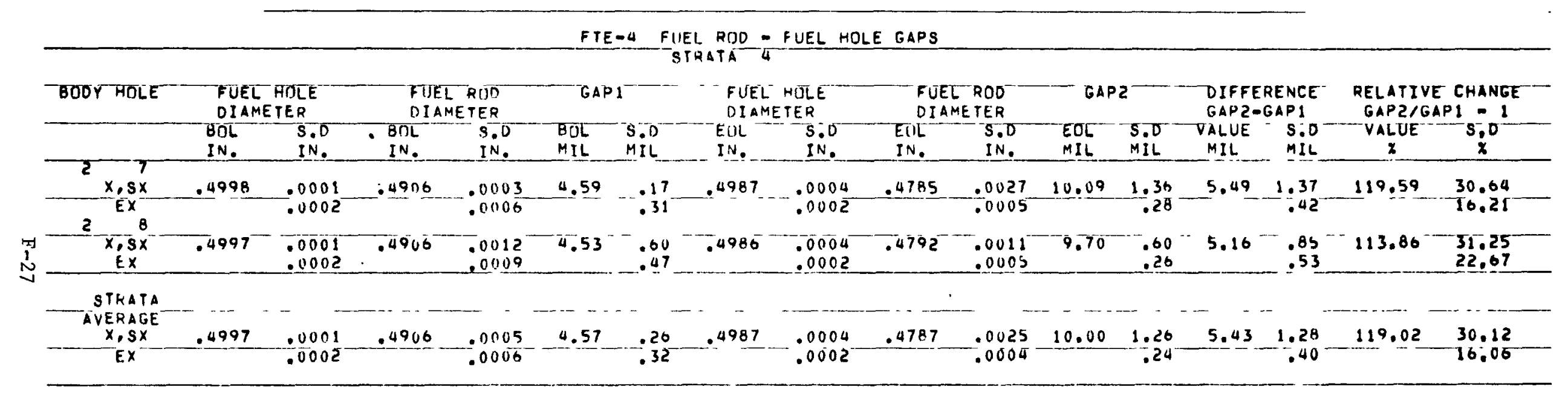

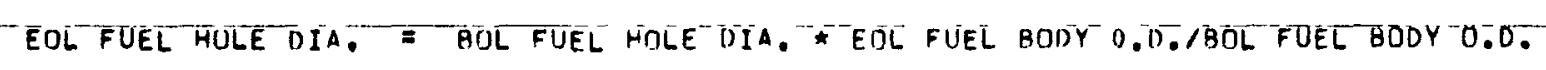


FTE-4 FUEL RUD - FUEL HOLE GAPS

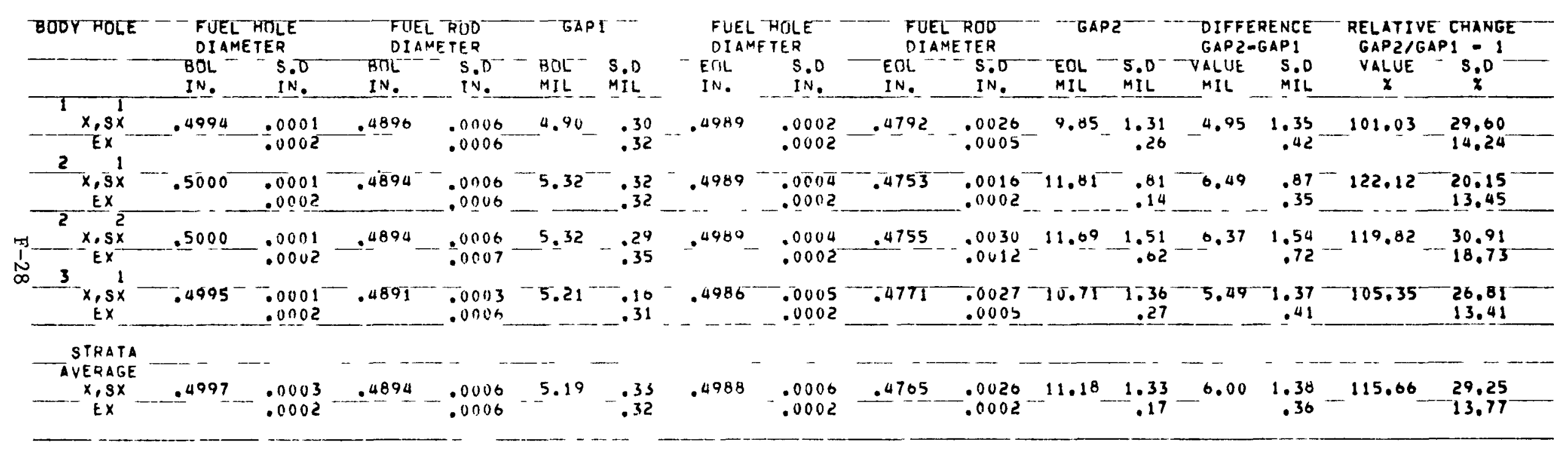

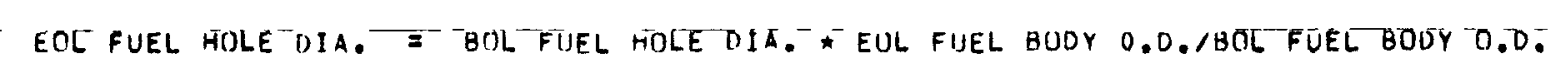


FTE-4 FIIEL RUD - FUEL HILE GAPS

\begin{tabular}{|c|c|c|c|c|c|c|c|c|c|c|c|c|c|c|c|c|}
\hline \multirow[t]{2}{*}{ BOOY HOLE } & \multicolumn{2}{|c|}{$\begin{array}{l}\text { FUEL HOLE } \\
\text { DI AMETER }\end{array}$} & \multicolumn{2}{|c|}{$\begin{array}{l}\text { FUEL RON } \\
\text { UIAMETER }\end{array}$} & \multicolumn{2}{|c|}{ GAPI- } & \multicolumn{2}{|c|}{$\begin{array}{l}\text { FUEL HOLE } \\
\text { OIAMETER }\end{array}$} & \multicolumn{2}{|c|}{$\begin{array}{l}\text { FUEL ROD } \\
\text { DIAMETER }\end{array}$} & \multicolumn{2}{|c|}{ GAPE } & \multicolumn{2}{|c|}{$\begin{array}{l}\text { OIFFERENCE - } \\
\text { GAP Z-GAPI }\end{array}$} & \multicolumn{2}{|c|}{$\begin{array}{l}\text { RELATIVE CHANGE } \\
\text { GAP } 2 / G A P I-1\end{array}$} \\
\hline & $\begin{array}{l}\text { BnL } \\
\text { IN. }\end{array}$ & $\begin{array}{l}\text { S.D } \\
\text { IN. }\end{array}$ & $\begin{array}{l}\text { BOL } \\
\text { IN. }\end{array}$ & S.D & $\begin{array}{l}B U L \\
M I L\end{array}$ & $\begin{array}{l}5.0 \\
\text { MIL }\end{array}$ & $\begin{array}{l}\text { EIIL } \\
\text { IN. }\end{array}$ & $\begin{array}{l}\text { S.D } \\
\text { IN. }\end{array}$ & $\begin{array}{l}\text { EDL } \\
\text { IN. }\end{array}$ & $\begin{array}{l}\text { S.O } \\
\text { IN. }\end{array}$ & $\begin{array}{l}\text { EOL } \\
\text { MIL }\end{array}$ & $\begin{array}{l}\text { S.O } \\
\text { MIL }\end{array}$ & $\begin{array}{l}\text { VALUE } \\
\text { MIL }\end{array}$ & $\begin{array}{l}\text { S.D } \\
\text { MIL }\end{array}$ & VALUE & $\begin{array}{c}-2: 0 \\
-2\end{array}$ \\
\hline$\frac{x^{3} x^{3}}{E x^{3}}$ & .4990 & $\begin{array}{l}.0001 \\
.0002\end{array}$ & .4914 & $.001 \frac{7}{.0007}$ & 3.82 & .86 & .4985 & $\begin{array}{l}.0002 \\
.0002\end{array}$ & .4840 & $\begin{array}{l}.0023 \\
.0004\end{array}$ & 7.29 & $\begin{array}{r}1.16 \\
.24\end{array}$ & 3.47 & $\begin{array}{r}1.93 \\
-.44\end{array}$ & 90.84 & $\begin{array}{l}51.58 \\
19.74\end{array}$ \\
\hline$\frac{2}{x \cdot s x^{3}}$ & .4998 & $\begin{array}{l}.0001 \\
.0002\end{array}$ & .4906 & $\begin{array}{l}.0008 \\
.0006\end{array}$ & 4.50 & $\begin{array}{r}.48 \\
.3\end{array}$ & -.4987 & $\begin{array}{l}.0004 \\
.0002\end{array}$ & .4802 & $\begin{array}{l}.0011 \\
.0002\end{array}$ & 9.28 & $\begin{array}{l}.57 \\
.15\end{array}$ & -4.69 & $\begin{array}{l}.70 \\
.36\end{array}$ & $-102 \cdot 10^{--}$ & $\begin{array}{l}21.58 \\
14.80\end{array}$ \\
\hline$x, s x$ & .4996 & $\begin{array}{l}.00001 \\
.00002\end{array}$ & .4898 & $\begin{array}{l}.0002 \\
.0006\end{array}$ & $\underline{4} .90$ & -11 & .4985 & $\begin{array}{l}.0004 \\
\because 01002\end{array}$ & .4801 & $\begin{array}{l}.0015 \\
.0006\end{array}$ & 9.20 &. .70 & 4.30 & $\begin{array}{r}.77 \\
-.45\end{array}$ & 87.83 & $\begin{array}{l}16.07 \\
13.79\end{array}$ \\
\hline $\begin{array}{c}x \cdot s x \\
E x\end{array}$ & .4995 & $\begin{array}{l}.0001 \\
.0002 \\
\end{array}$ & .4906 & $\begin{array}{l}.001 A \\
.0007\end{array}$ & 4.43 & .88 & .4986 & $\begin{array}{l}.0005 \\
.0002 \\
\end{array}$ & .0813 & $\begin{array}{l}.0010 \\
.0003\end{array}$ & 8.62 & $\begin{array}{r}.82 \\
.18\end{array}$ & -4.19 & $\begin{array}{r}1.22 \\
.43\end{array}$ & $94.66^{-}$ & $\begin{array}{l}43.40 \\
17.35\end{array}$ \\
\hline $\begin{array}{c}\text { STRATA } \\
\text { AVVERAGE } \\
X, S X \\
\text { EX }\end{array}$ & .4995 & $\begin{array}{l}.0003 \\
.0002\end{array}$ & .4908 & $\begin{array}{l}.0015 \\
.0006\end{array}$ & 4.33 & $\begin{array}{r}-: \\
-.76 \\
.34\end{array}$ & .4986 & $\begin{array}{l}.0000 \\
.0002\end{array}$ & .4817 & $\begin{array}{l}.0023 \\
.0003\end{array}$ & 8.44 & $\begin{array}{r}1.20 \\
.18\end{array}$ & 4.11 & $\begin{array}{r}1.42 \\
.38\end{array}$ & 94.86 & $\begin{array}{l}43.93 \\
15.73\end{array}$ \\
\hline
\end{tabular}

EOL FUEL HULE DIA. $=$ BIT FUEL TIIE DIA. * EOL FIIEL BODY $0.0 .180 L$ FUEL BODY $0.0 . \cdots$ 
FTE- 4 FIIEL ROD - FUEL HOLE GAPS

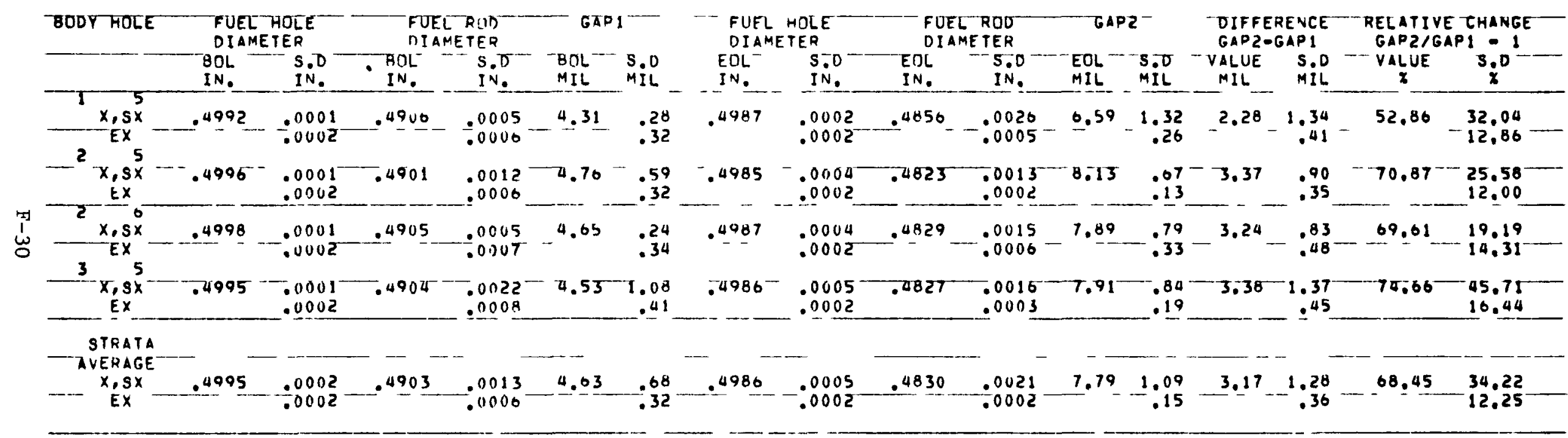

- EDL FUEL HOLE DIA.- $=$ BUL FUEL HOLE DIA. * EOL FUEL BODY $0.0_{.} /$BOL FUEL BODY 0.0. 


\section{-}

FTE-A FIIEL ROU - FUEL HOLE GAPS STRATA B

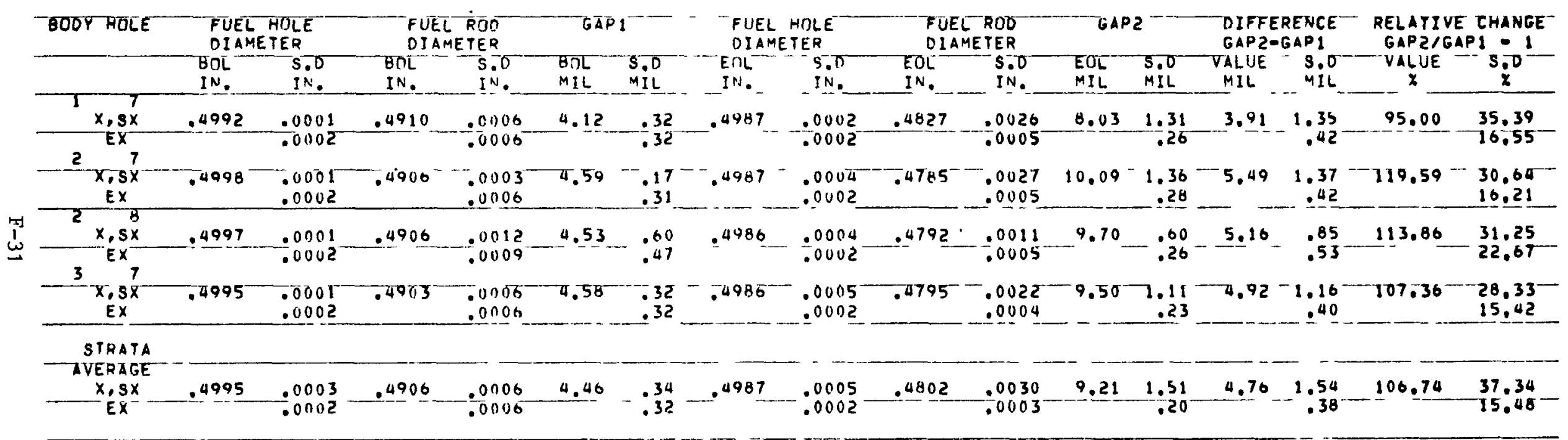

EOL FUEL HOLE OIA. $=$ HOL FUEL HOLE DIA. * EOL FUEL BODY $0.0 .180 L$ FUEL BODY 0.0 . 


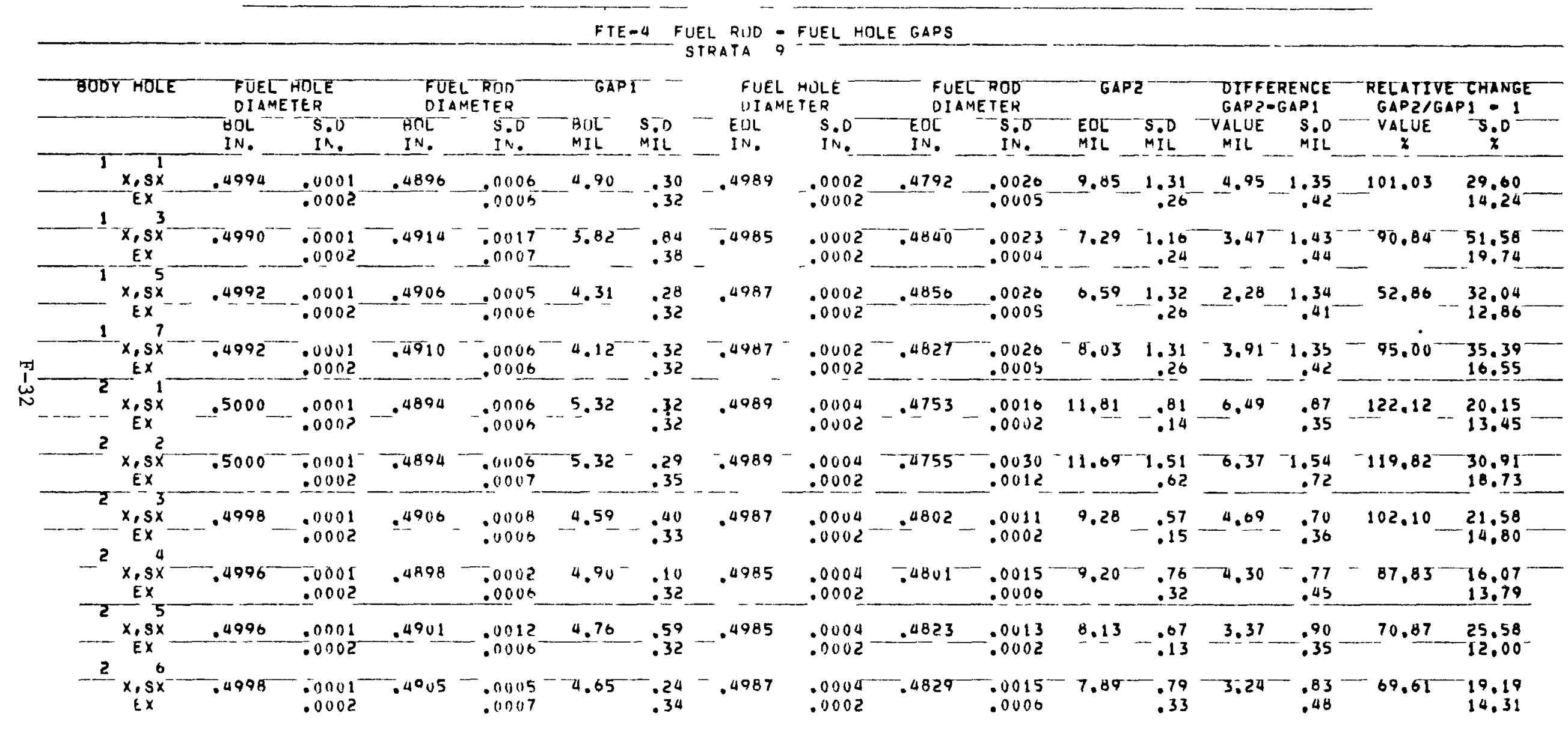




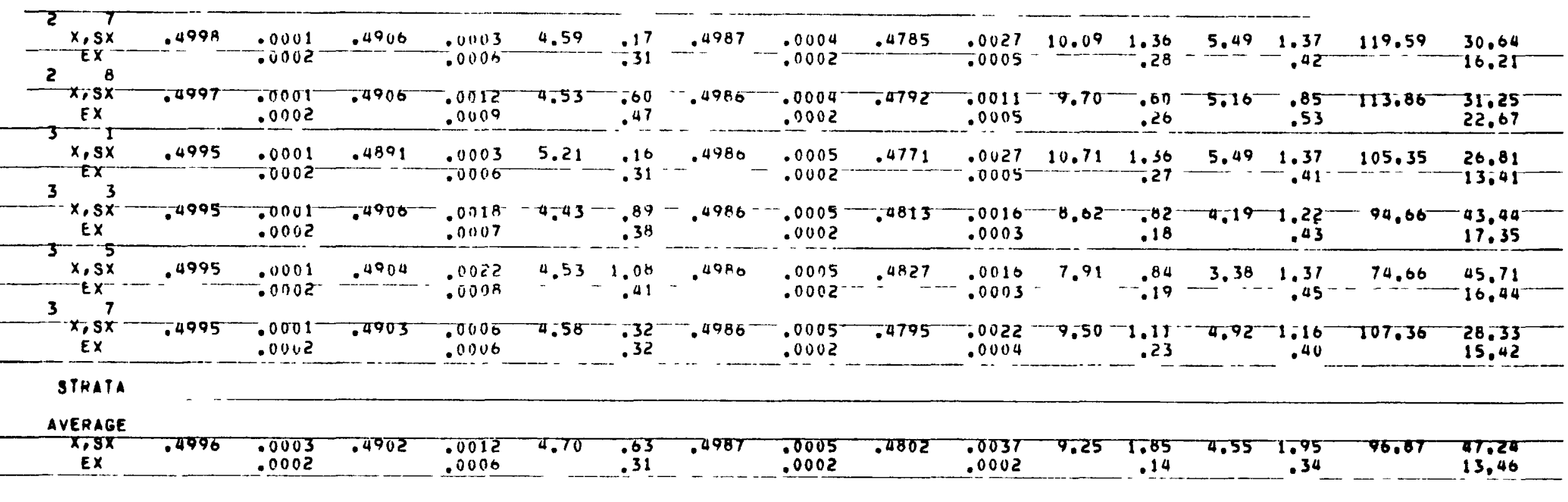

EOL FUEL HULE DIA. $\doteq$ BOL FUEL HOLE DIA. ¿ EOL FUEL BODY $0.0 .18 O L$ FUEL BODY 0.0 . 
FTE-4 SLEEVE - FUEL BNDY GAPS (FRUM SLEEVE U.D.)

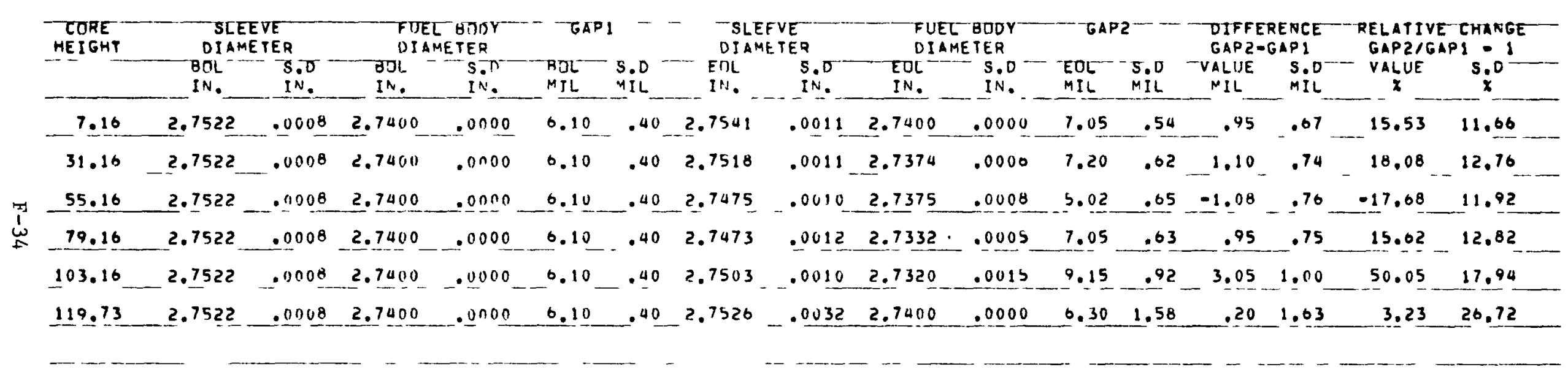

EOL SLEEVE OIA. = BOL SLEFVE 1.0. EOL SLEEVE $0.0 .180 L$ SLEEVE 0.0 . 
FTE-4 SLEEVE - FUEL BOUY GAPS (FROM SLEEVE 0.0. .)

\begin{tabular}{|c|c|c|c|c|c|c|c|c|c|c|c|c|c|c|c|c|}
\hline \multirow[t]{2}{*}{$\begin{array}{l}\text { FUEL } \\
\text { BODY }\end{array}$} & \multicolumn{2}{|c|}{$\begin{array}{l}\text { SLEEVE } \\
\text { OIAMETER }\end{array}$} & \multicolumn{2}{|c|}{$\begin{array}{l}\text { FUET } \bar{\beta} \text { RIOY } \\
\text { DIAMETFR }\end{array}$} & \multicolumn{2}{|c|}{ GAPI } & \multicolumn{2}{|c|}{$\begin{array}{l}\text { SLEEVE } \\
\text { DIAMETER }\end{array}$} & \multicolumn{2}{|c|}{$\begin{array}{l}\text { FUEL BOUY } \\
\text { DIAMETER }\end{array}$} & \multicolumn{2}{|c|}{ GAP2 } & \multicolumn{2}{|c|}{$\begin{array}{l}\text { DIFFERENCE } \\
\text { GAPL-GAPI }\end{array}$} & \multicolumn{2}{|c|}{$\begin{array}{l}\text { RELATIVE CHANGE } \\
\text { GAPZ/GAPI }=1\end{array}$} \\
\hline & $\begin{array}{l}8 \pi L^{-1} \\
1 \mathrm{~N} .\end{array}$ & $\begin{array}{l}\text { S. } \\
\text { IN. }\end{array}$ & $\begin{array}{l}\text { BOL } \\
\text { IN. }\end{array}$ & $\begin{array}{l}S .15 \\
1 \mathrm{~V} .\end{array}$ & $\begin{array}{l}\text { BiL- } \\
\text { MIL }\end{array}$ & $\begin{array}{l}S .0 \\
\text { MIL }\end{array}$ & $\begin{array}{l}\text { EUL. } \\
\text { IN. }\end{array}$ & $\begin{array}{l}3.0 \\
I N .\end{array}$ & $\begin{array}{l}\text { EOL } \\
\text { IN. }\end{array}$ & $\begin{array}{l}\text { S.0 } \\
\text { IN. }\end{array}$ & $\begin{array}{l}E O L- \\
\text { MIL }\end{array}$ & $\begin{array}{l}\text { S.D } \\
\text { MIL }\end{array}$ & $\begin{array}{l}\text { VALUE } \\
\text { MIL }\end{array}$ & $\begin{array}{l}\text { S.O } \\
\text { MIL }\end{array}$ & -VALUE & ${ }^{2} ; 0$ \\
\hline 1 & 2.7522 & .0005 & 2.7400 & .0000 & 0.10 & .40 & 2.7518 & .0011 & 2.7375 & .0011 & 7.15 & .78 & 1.05 & .88 & 17.26 & 14.98 \\
\hline 2 & 2.7522 & .0008 & 2.7400 & .0000 & 0.10 & .40 & 2.7474 & .0009 & 2.7341 & .0023 & 0.60 & 1.22 & .50 & 1.29 & 9.22 & 21.30 \\
\hline 3 & 2.7522 & .0008 & 2.7400 & .0000 & 6.10 & .40 & 2.7503 & .0010 & 2.7348 & .0025 & 7.75 & 1.33 & 1.65 & 1.39 & 27.10 & 23.42 \\
\hline ELEMENT & & & & & & & & & & & & & & & & \\
\hline $\begin{array}{r}\text { AVERAGE } \\
X, S X \\
\\
E X\end{array}$ & 2.7522 & $\begin{array}{l}.0008 \\
.0005\end{array}$ & 2.7400 & $\begin{array}{l}.0000 \\
.0005\end{array}$ & 6.10 & $\begin{array}{r}.40 \\
-.30\end{array}$ & 2.7492 & $\begin{array}{r}.0022 \\
.0009\end{array}$ & 2.7354 & $\begin{array}{l}.0025 \\
.0004\end{array}$ & 6.92 & $\begin{array}{r}1.07 \\
-.51\end{array}$ & .82 & $\begin{array}{r}1.72 \\
-.959\end{array}$ & 13.44 & $\begin{array}{l}26.43 \\
70.07\end{array}$ \\
\hline
\end{tabular}

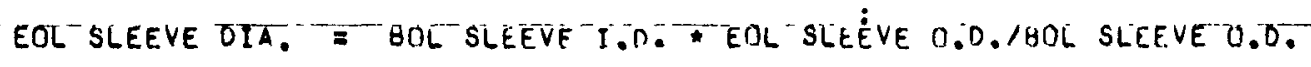


FTE-4 SLEEVE - FUEL BODY GAPS (FROM SLEEVE 1.0.)

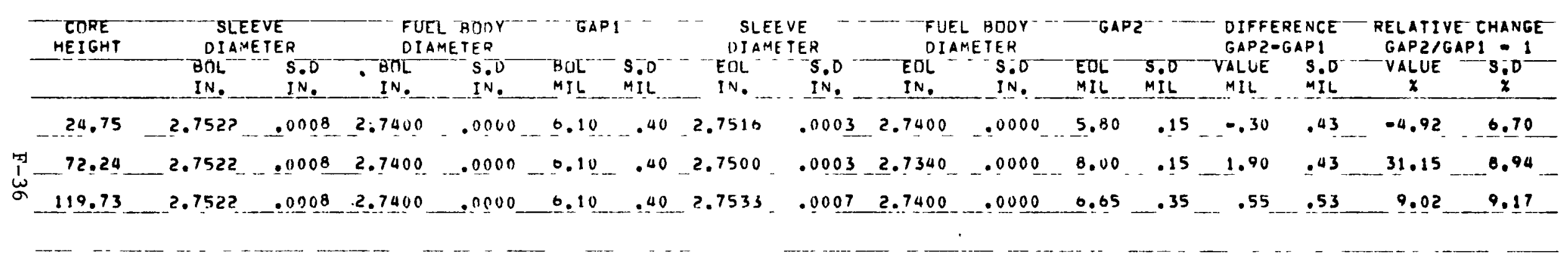


FTE - 4 SLFEVE - FUEL RMOY GAPS (FROM SLEEYE I.D.)

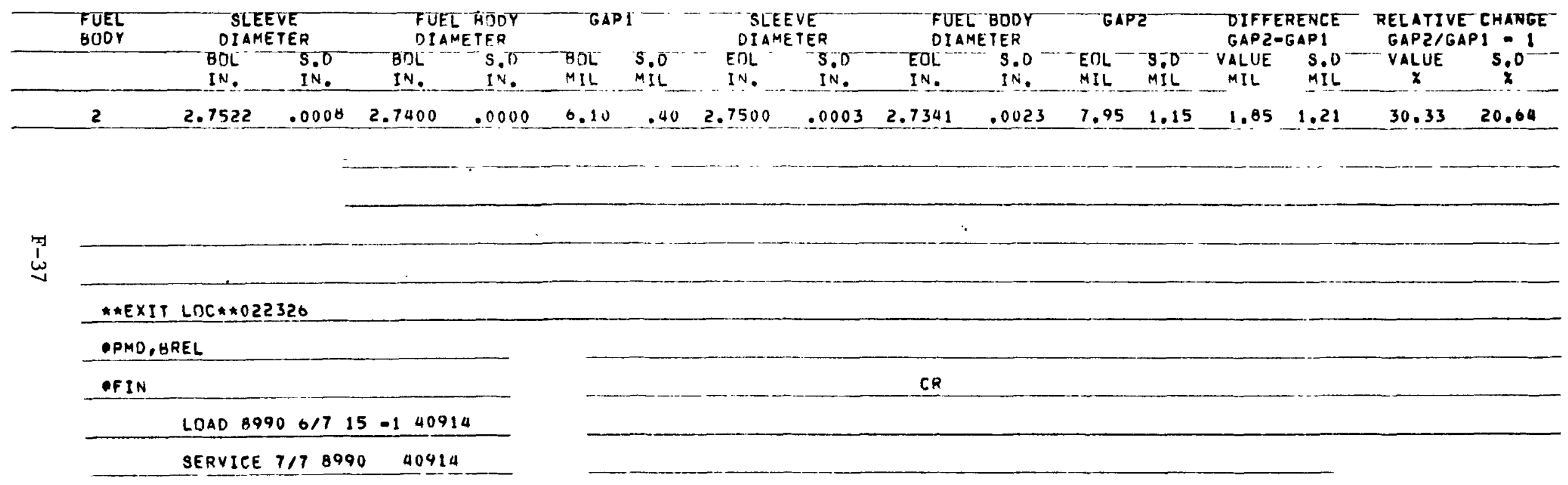


FUEL RIO-FUEL HULE GAPS HOLES 182 ULIT TRISO (22\% FUEL VIL) ANA THUZ BISU (7B\% FUEL VOL, FUEL

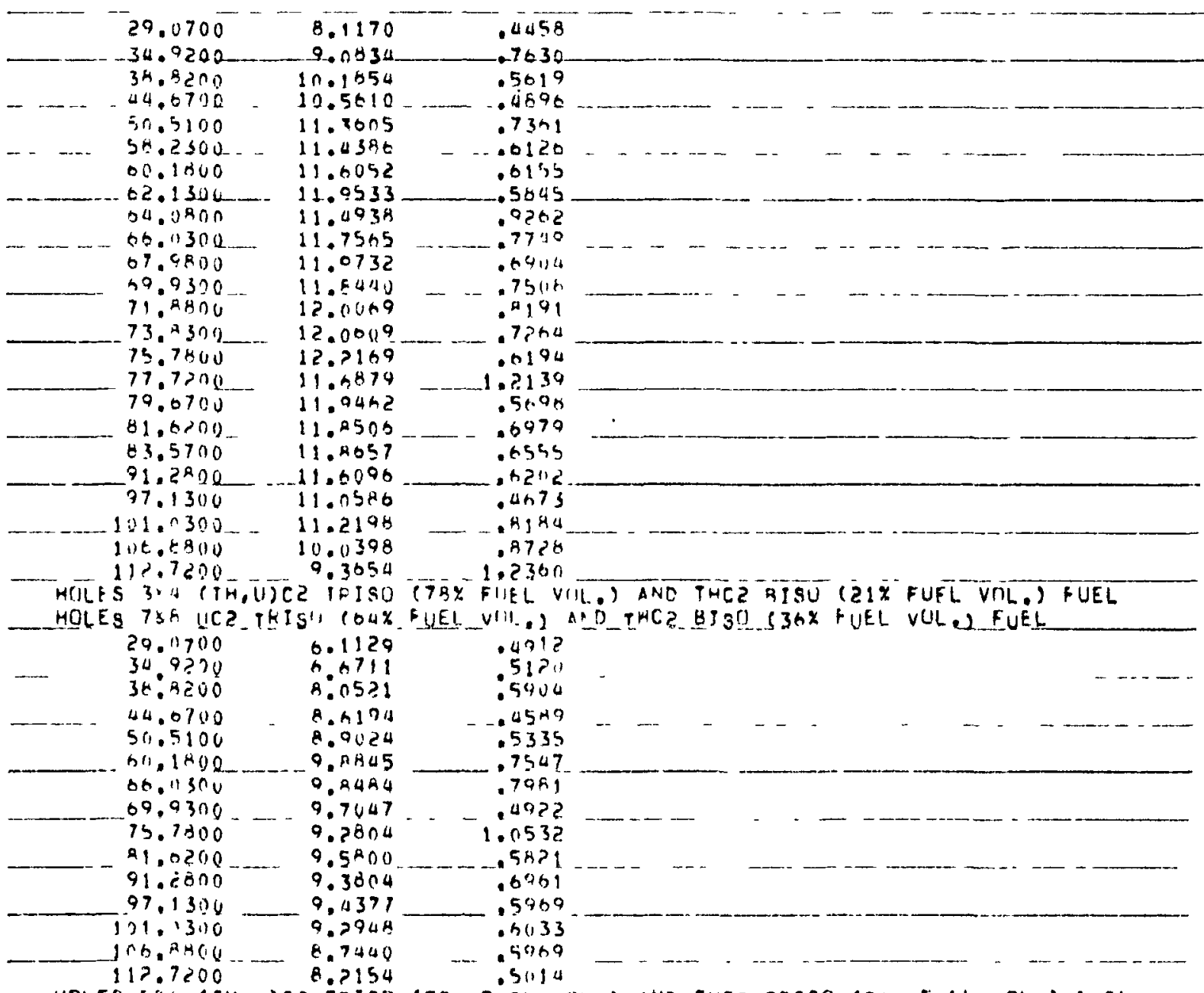

HOLES SBO (IH.U)C2 TRISO_(79\% FUEL VILLL AND IHES TRISO (21X FUEL VOL.) FUEL ...

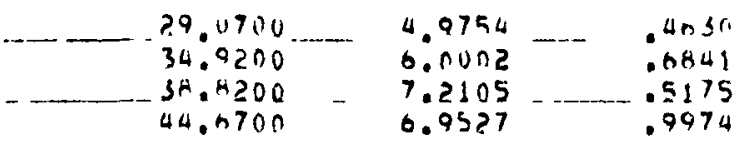




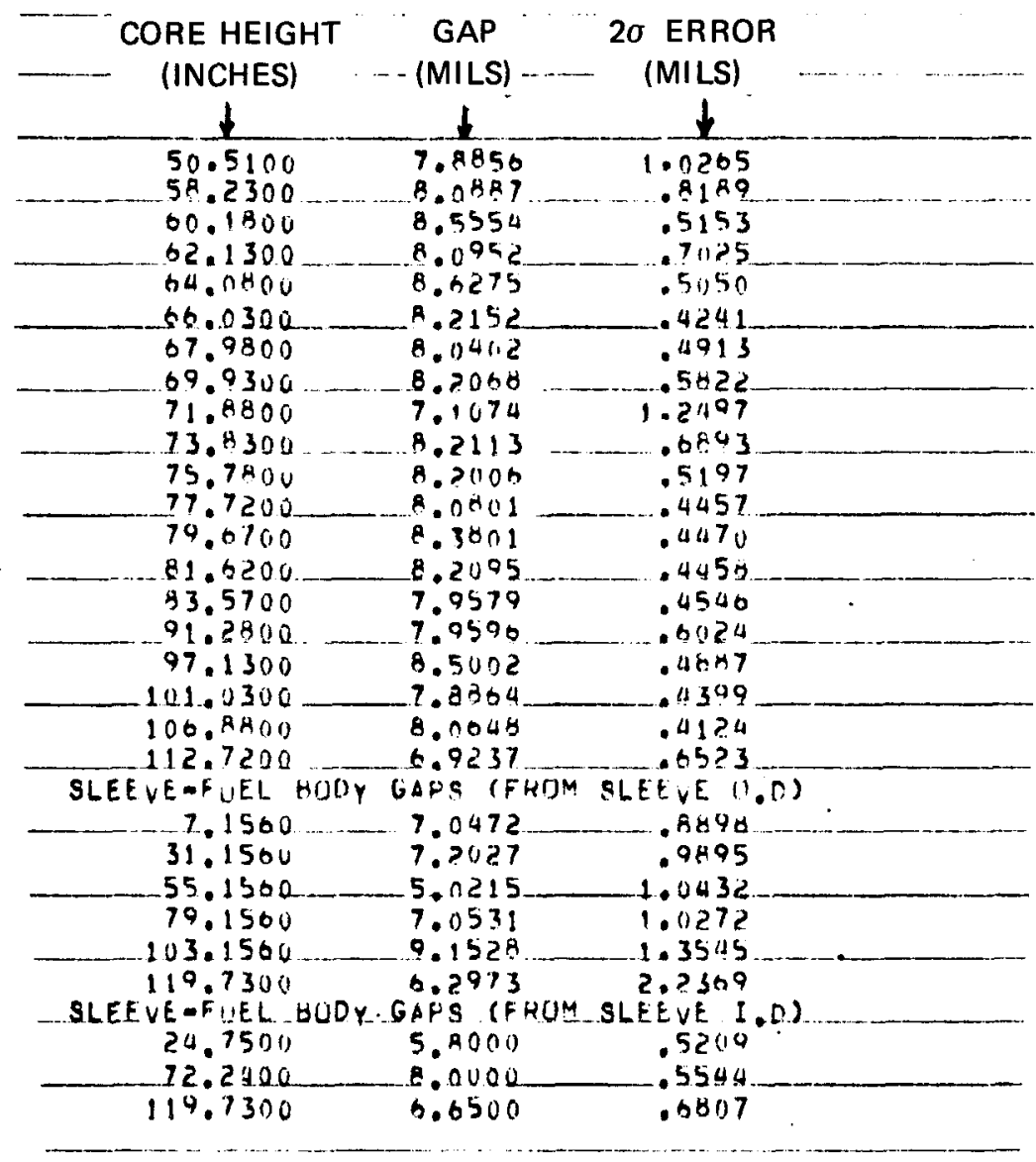


APPENDIX G

DRWDIM INPUT INSTRUCTIONS 


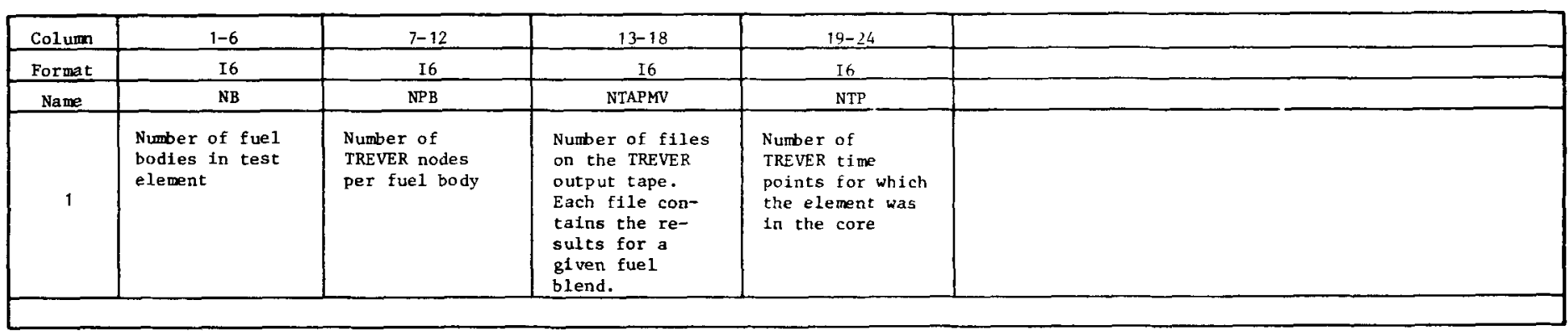
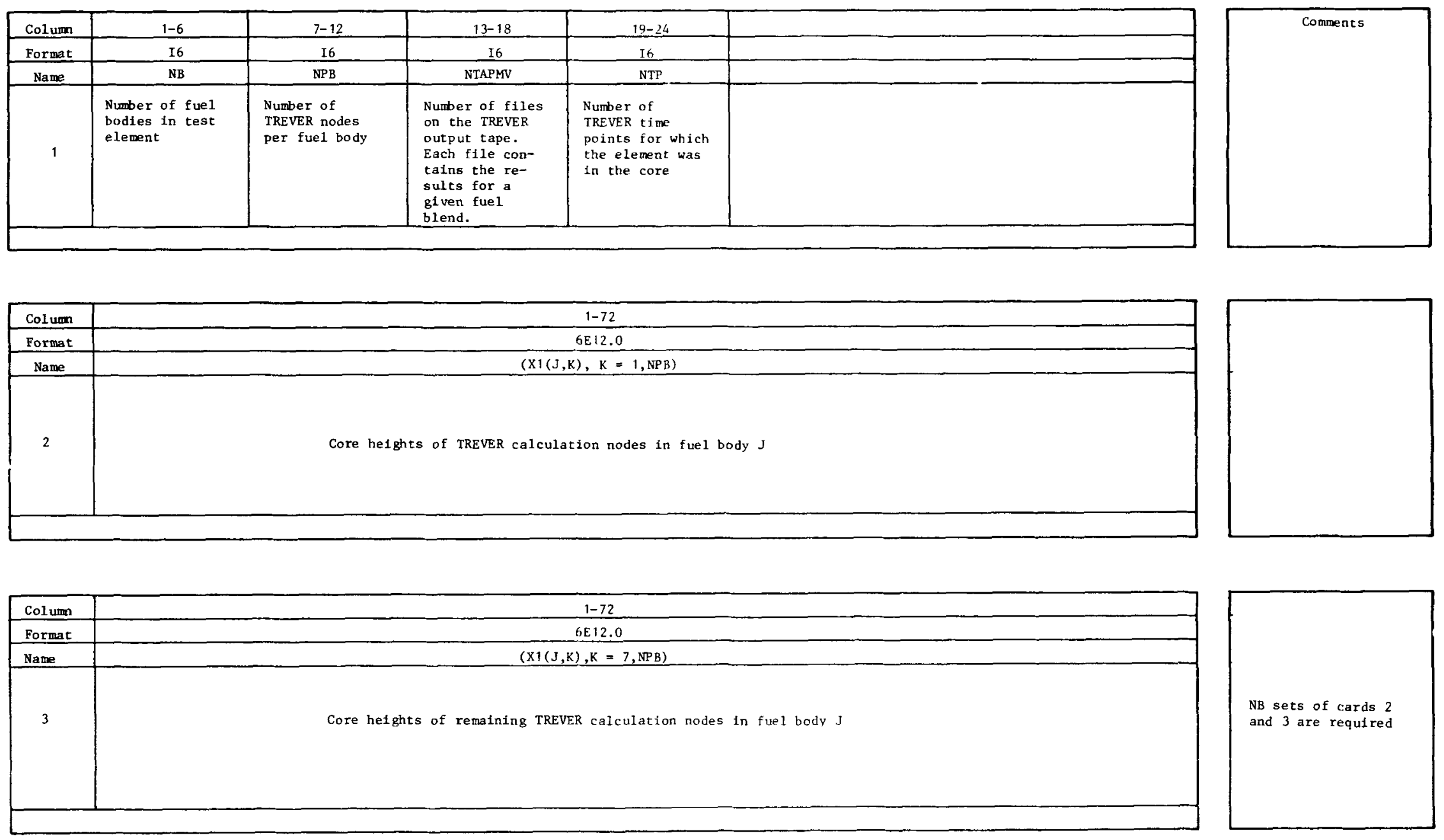


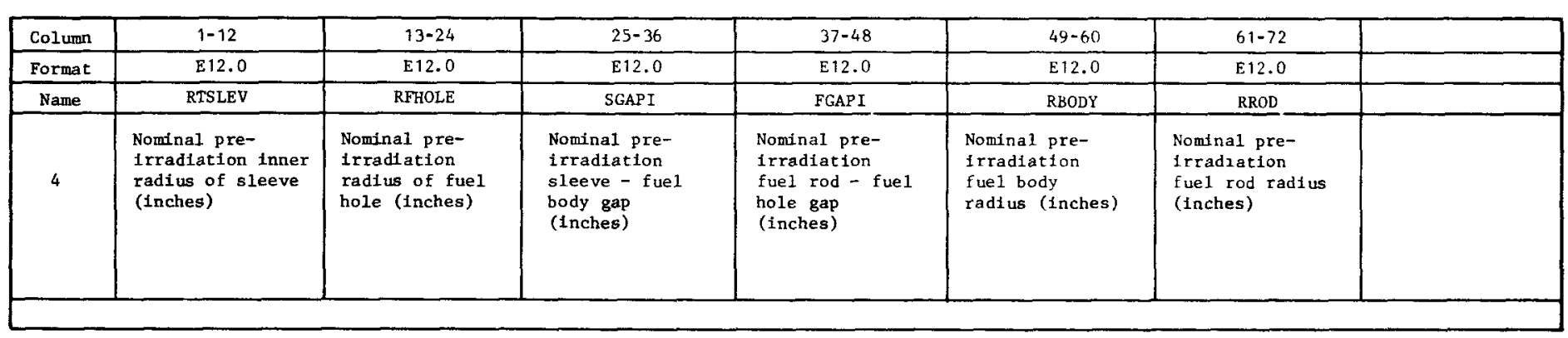

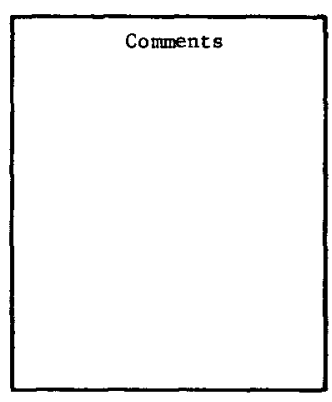

\begin{tabular}{|c|c|c|c|c|c|c|}
\hline Col umn & $1-6$ & $7-12$ & 13-18 & $19-24$ & $25-30$ & \\
\hline Pormat & 16 & I6 & 16 & I6 & 16 & \\
\hline Name & $M 1(1)$ & M1(2) & M1(3) & M1 (4) & M1 (5) & \\
\hline 5 & $\begin{array}{l}1 \text { - Plot sleeve - } \\
\text { fuel body } \\
\text { gaps and } 2 \sigma \\
\text { errors } \\
0 \text { - Do not plot }\end{array}$ & $\begin{array}{l}1 \text { - Plot fuel } \\
\text { rod - fuel } \\
\text { hole gaps } \\
\text { and } 2 \sigma \\
\text { errors } \\
0 \text { - Do not plot }\end{array}$ & $\begin{array}{l}1 \text { - Plot sleeve } \\
\text { strains and } \\
2 \sigma \text { errors } \\
0 \text { - Do not plot }\end{array}$ & $\begin{array}{l}1 \text { - Plot fue } 1 \\
\text { body strains } \\
\text { and } 20 \\
\text { errors } \\
0 \text { - Do not plot }\end{array}$ & $\begin{array}{l}1 \text { - Plot fue } 1 \\
\text { rod strains } \\
\text { and } 20 \text { errors } \\
0 \text { - Do not plot }\end{array}$ & \\
\hline
\end{tabular}

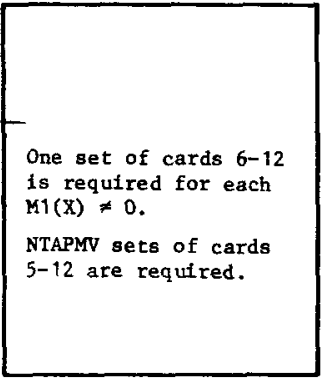

\begin{tabular}{|c|c|c|c|c|c|}
\hline Colum & $1-12$ & $13-24$ & $25-36$ & $37-48$ & \\
\hline Format & F12.4 & F12.4 & F12.4 & F12.4 & \\
\hline Name & SIZE(1) & SIZE(2) & SIZE(3) & SIZE(4) & \\
\hline 6 & $\begin{array}{l}\text { Minimum X co- } \\
\text { ordinate for } \\
\text { plot frame } \\
\text { (mi111meters) }\end{array}$ & $\begin{array}{l}\text { Maximum X co- } \\
\text { ordinate for } \\
\text { plot frame } \\
\text { (mi111meters) }\end{array}$ & $\begin{array}{l}\text { Minimum Y co- } \\
\text { ordinate for } \\
\text { plot frame } \\
\text { (\% or mi1s) }\end{array}$ & $\begin{array}{l}\text { Maxdmum Y co- } \\
\text { ordinate for } \\
\text { plot frame } \\
\text { (\% or mils) }\end{array}$ & \\
\hline
\end{tabular}

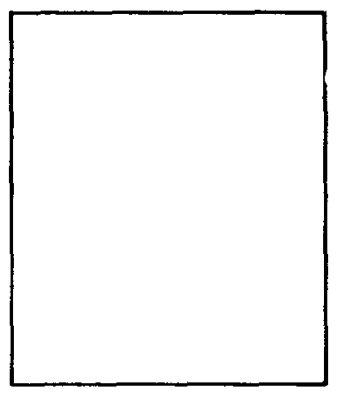




\begin{tabular}{|c|c|c|c|}
\hline Col umn & $1-6$ & -78 & \\
\hline Format & I6 & 12A6 & \\
\hline Name & & FTIT & \\
\hline 7 & $\begin{array}{l}\text { Number of alpha- } \\
\text { numeric chara- } \\
\text { ters 1n FTIT. } \\
\begin{array}{l}\text { Must be right } \\
\text { justified. }\end{array}\end{array}$ & Tit1e of plot frame & \\
\hline
\end{tabular}
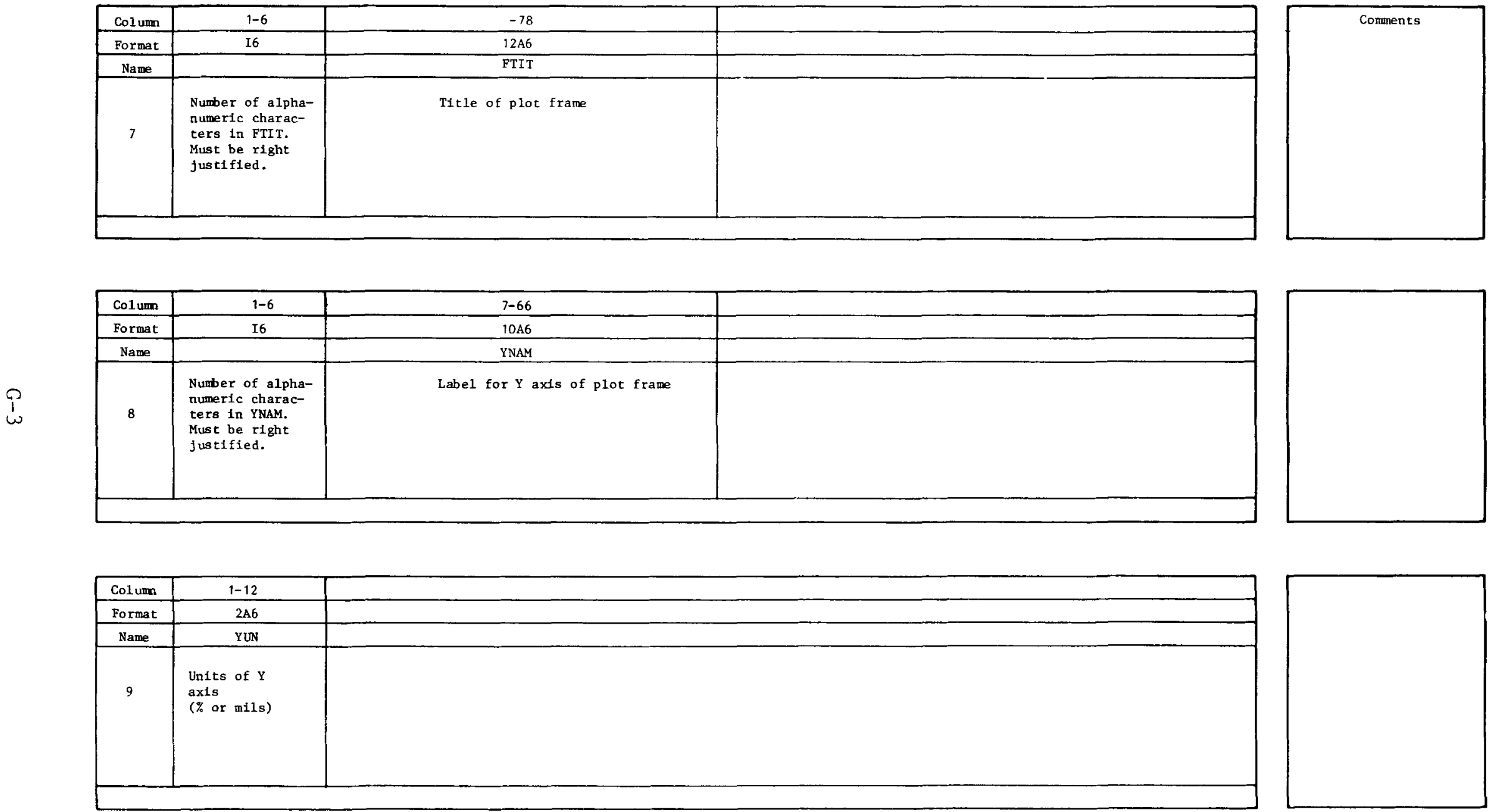


\begin{tabular}{|l|l|l|}
\hline Column & \multicolumn{1}{|c|}{$1-6$} & \\
\hline Format & I6 & \\
\hline Name & NuMB & \\
\hline 10 & $\begin{array}{l}\text { Number of sets } \\
\text { of measured } \\
\text { data to be } \\
\text { plotted on } \\
\text { plot frame }\end{array}$ & \\
\hline
\end{tabular}
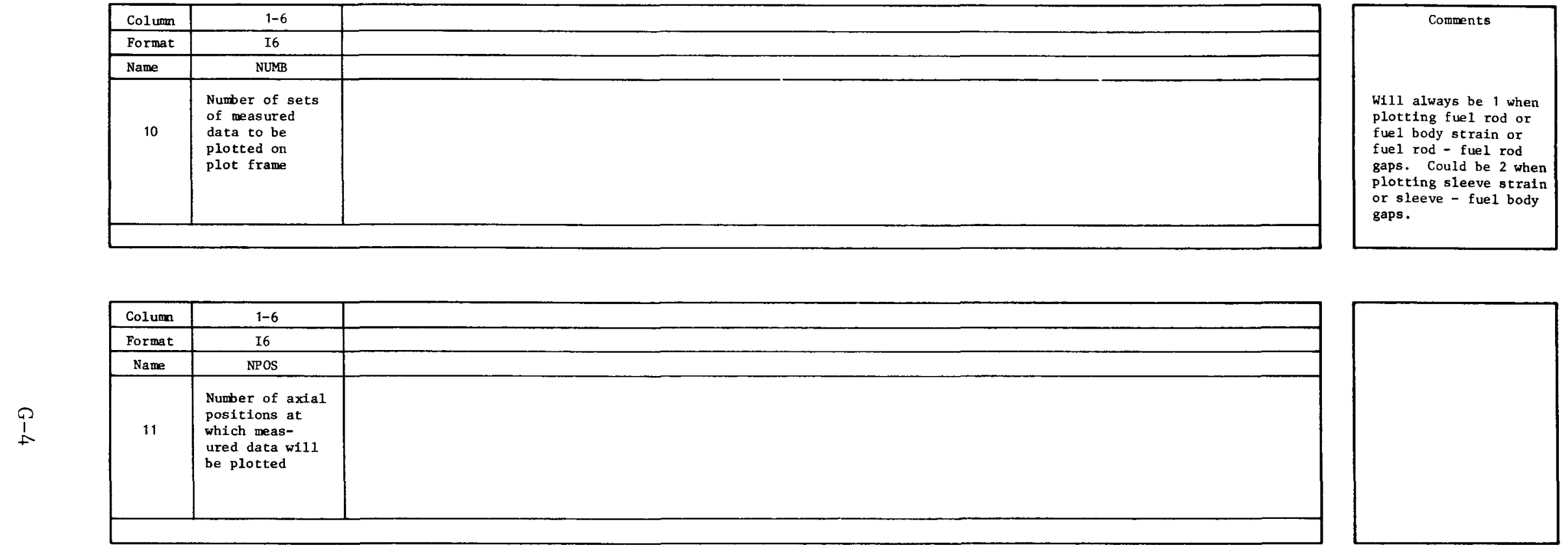

\begin{tabular}{|c|c|c|c|c|}
\hline Column & $1-12$ & $12-24$ & $25-36$ & \\
\hline Format & E12.0 & E12.0 & E12.0 & \\
\hline Name & XPOS & YAV & ERROR & \\
\hline 12 & $\begin{array}{l}\text { Axdal position } \\
\text { of measured } \\
\text { data to be } \\
\text { plotted }\end{array}$ & $\begin{array}{l}\text { Value of strain } \\
\text { or gap to be } \\
\text { plotted }\end{array}$ & $\begin{array}{l}2 \sigma \text { combined ran- } \\
\text { dom error on } \\
\text { YAV }\end{array}$ & $\begin{array}{l}\text { These cards are punched output } \\
\text { from GAPS, STRAIN, or STAT }\end{array}$ \\
\hline
\end{tabular}

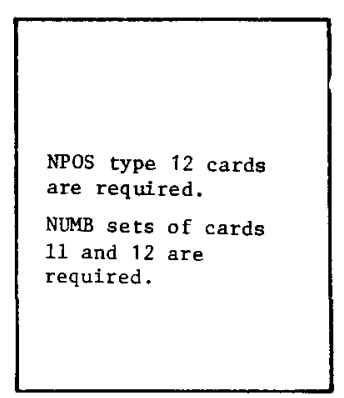


APPENDIX $\mathrm{H}$

DRWDIM SAMPLE PROBLEM 


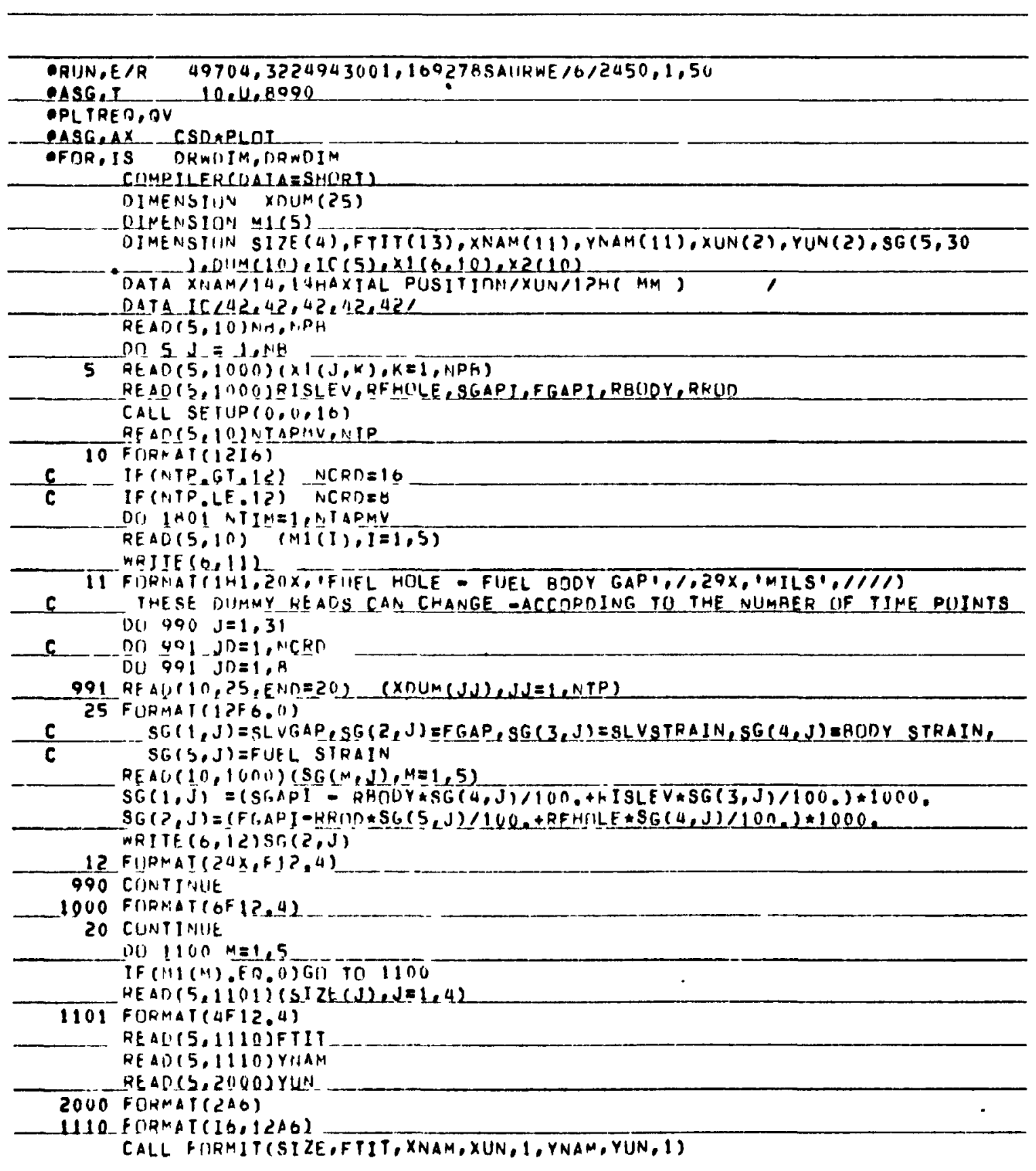




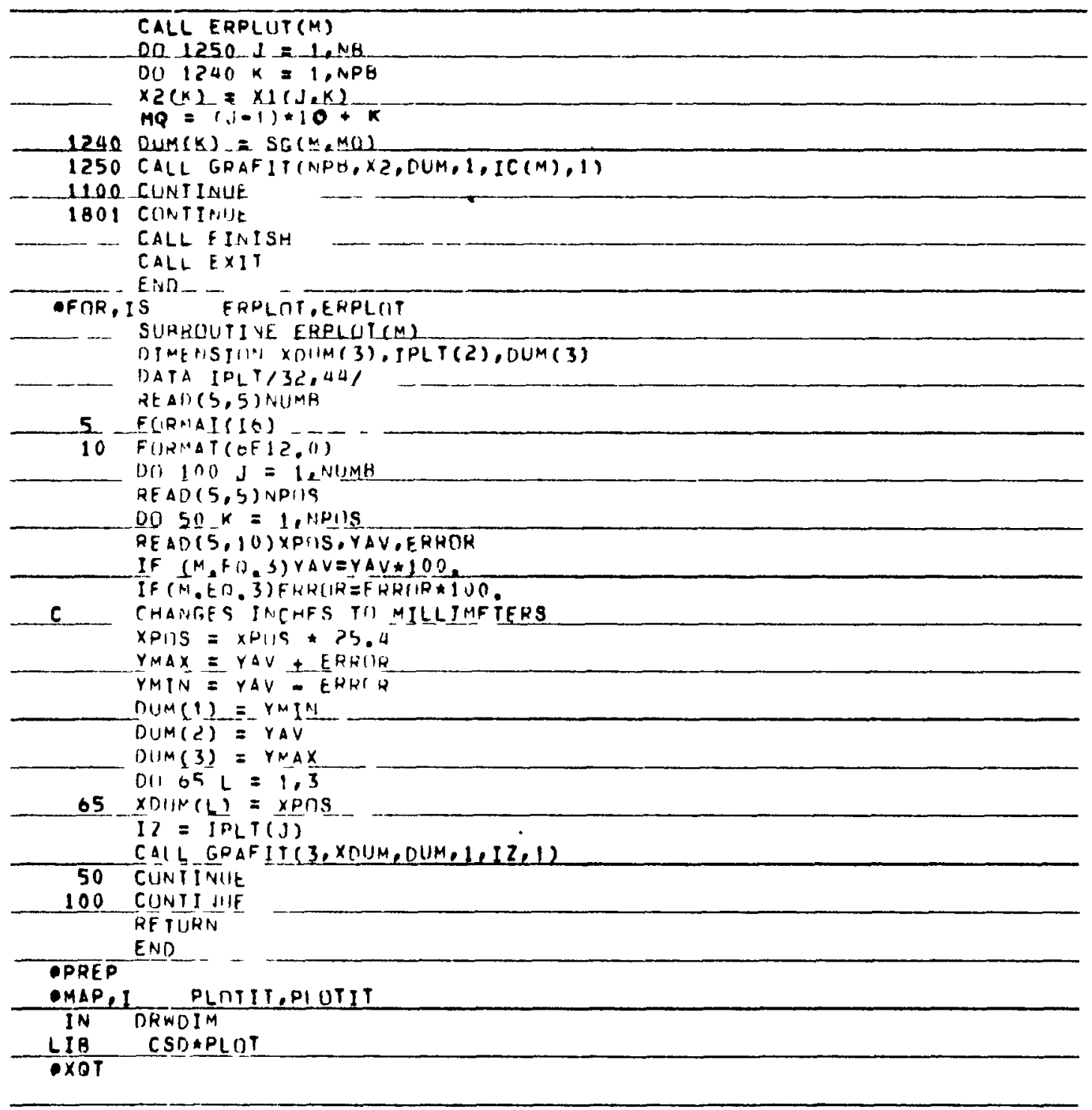

INPUT DATA DFCK FOR ORWDIM SAMPLE PROBLEM 


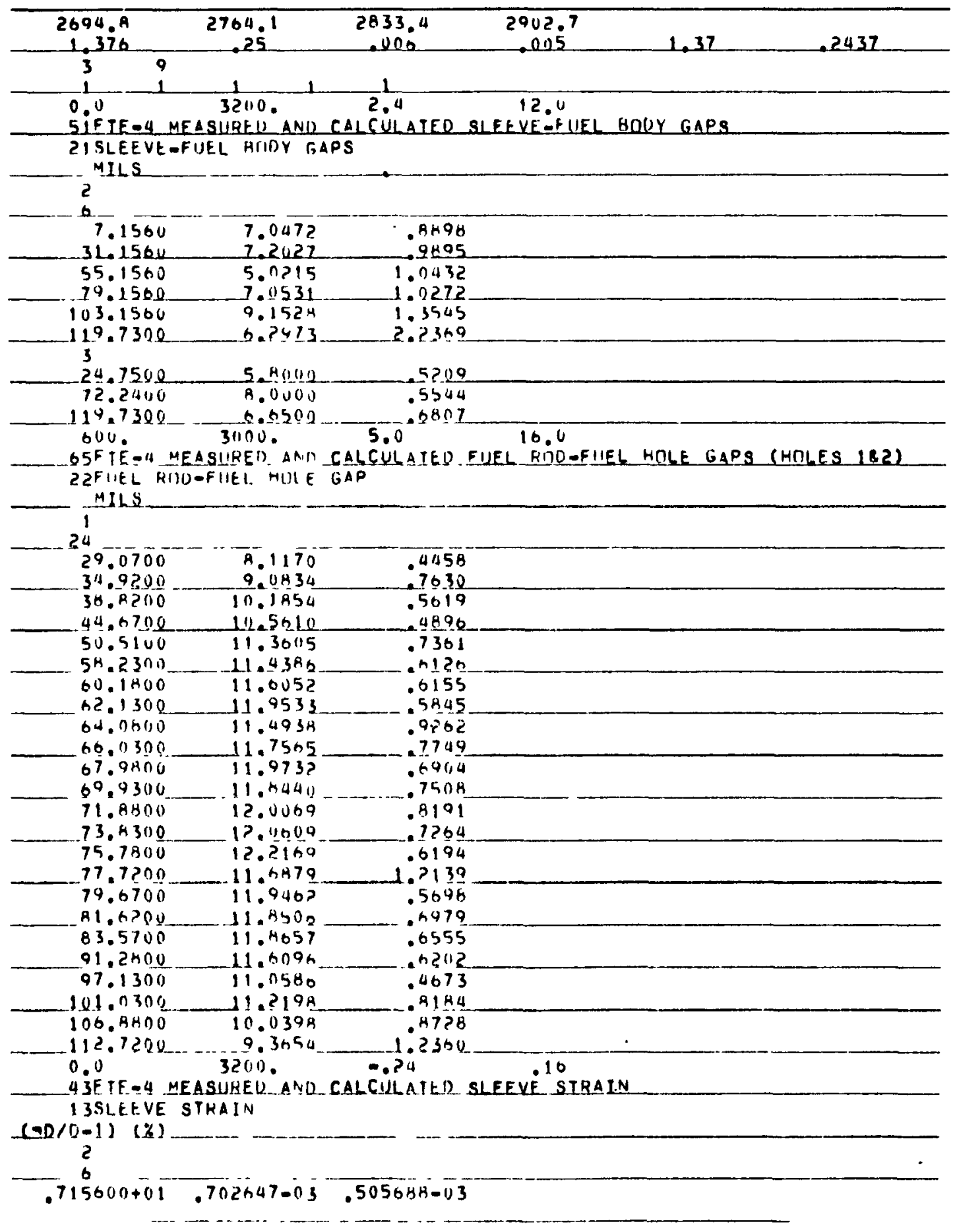




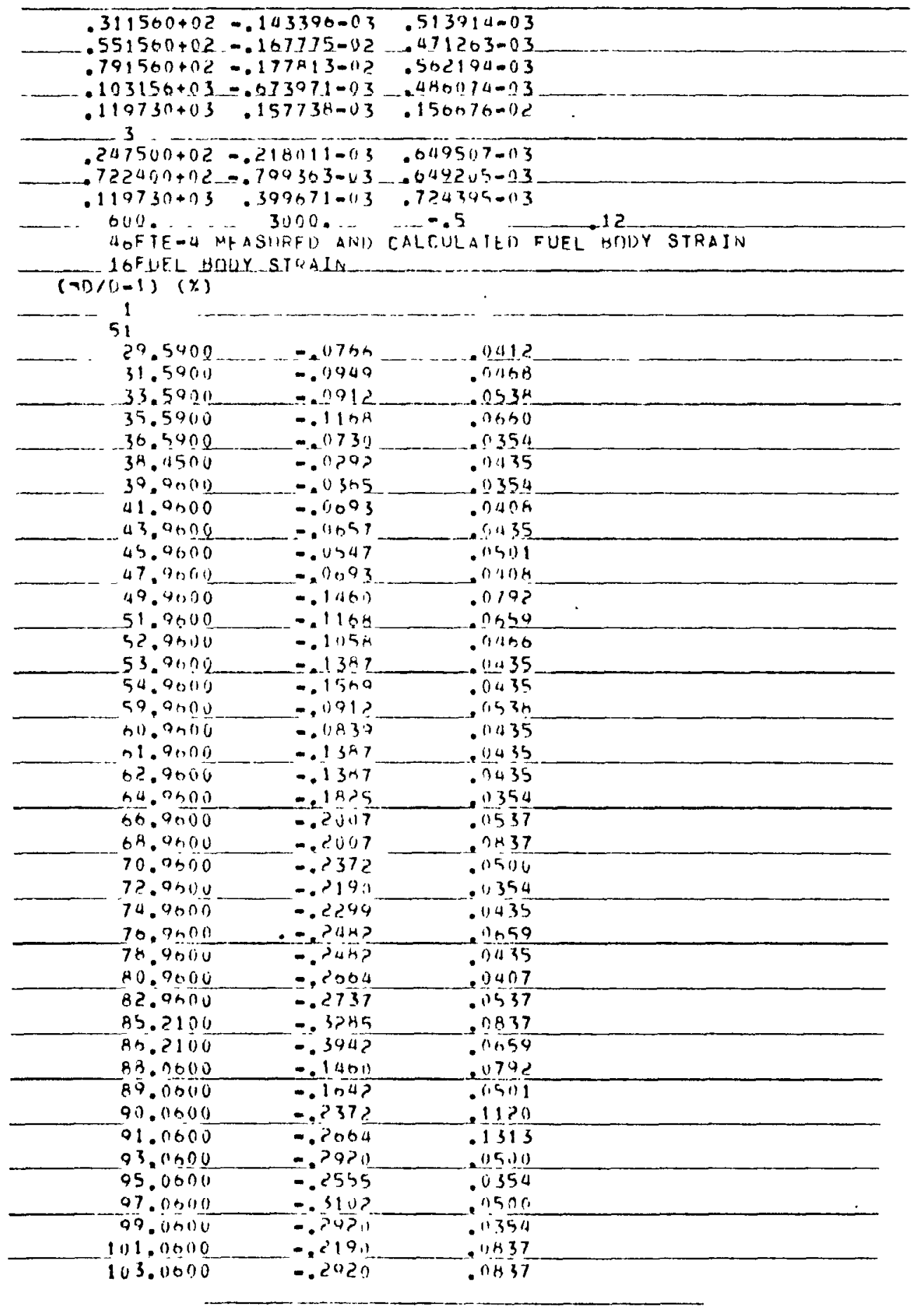




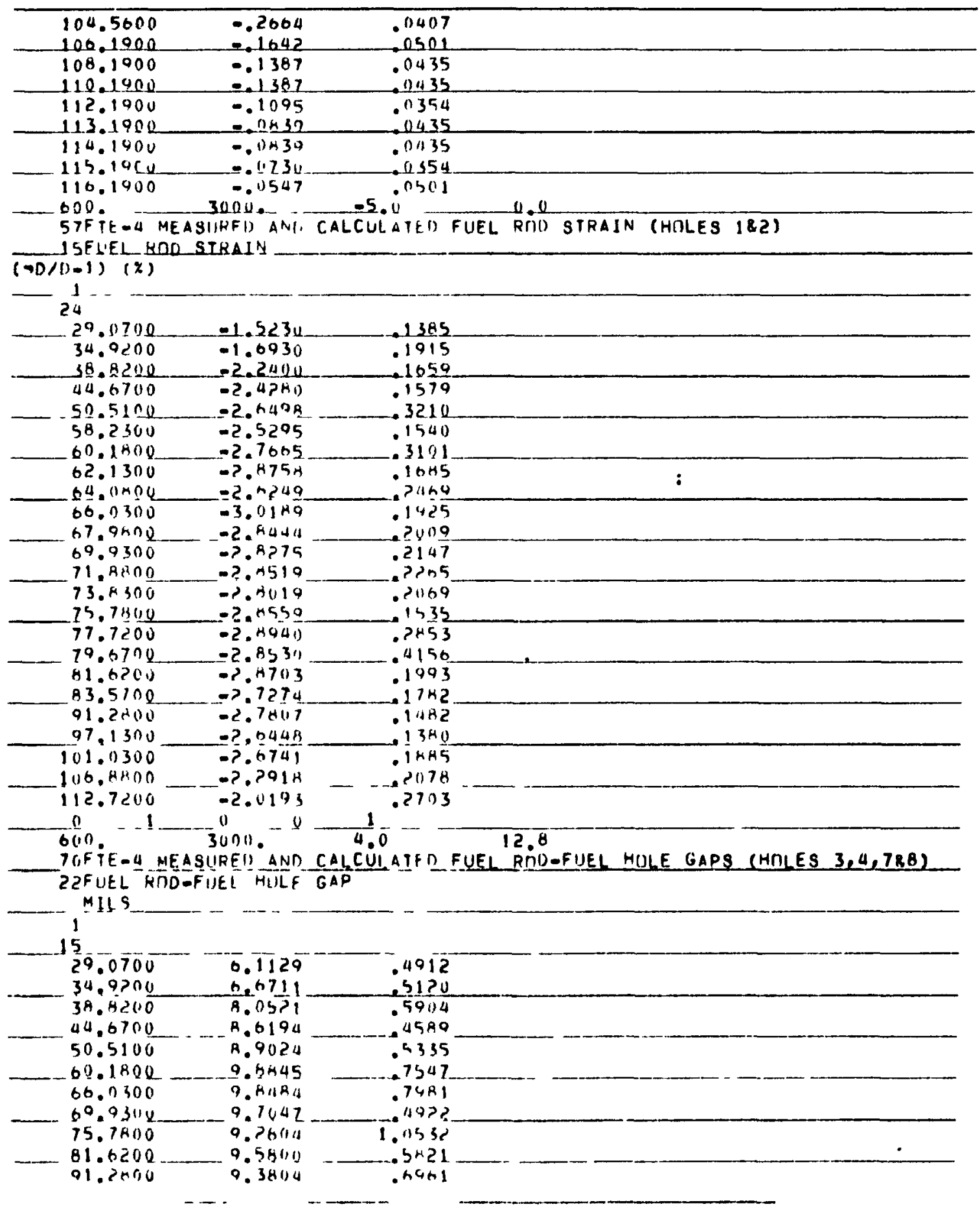




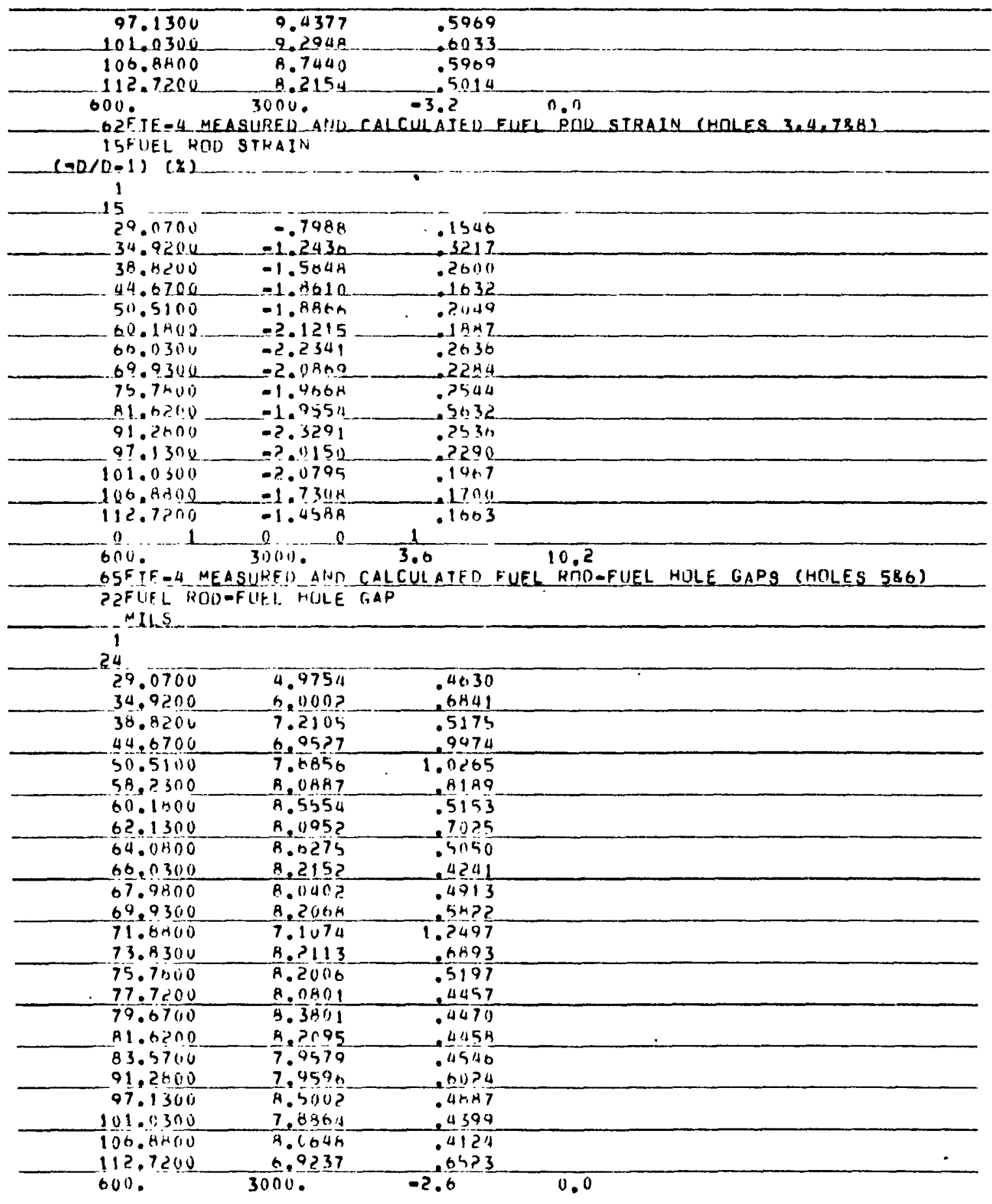




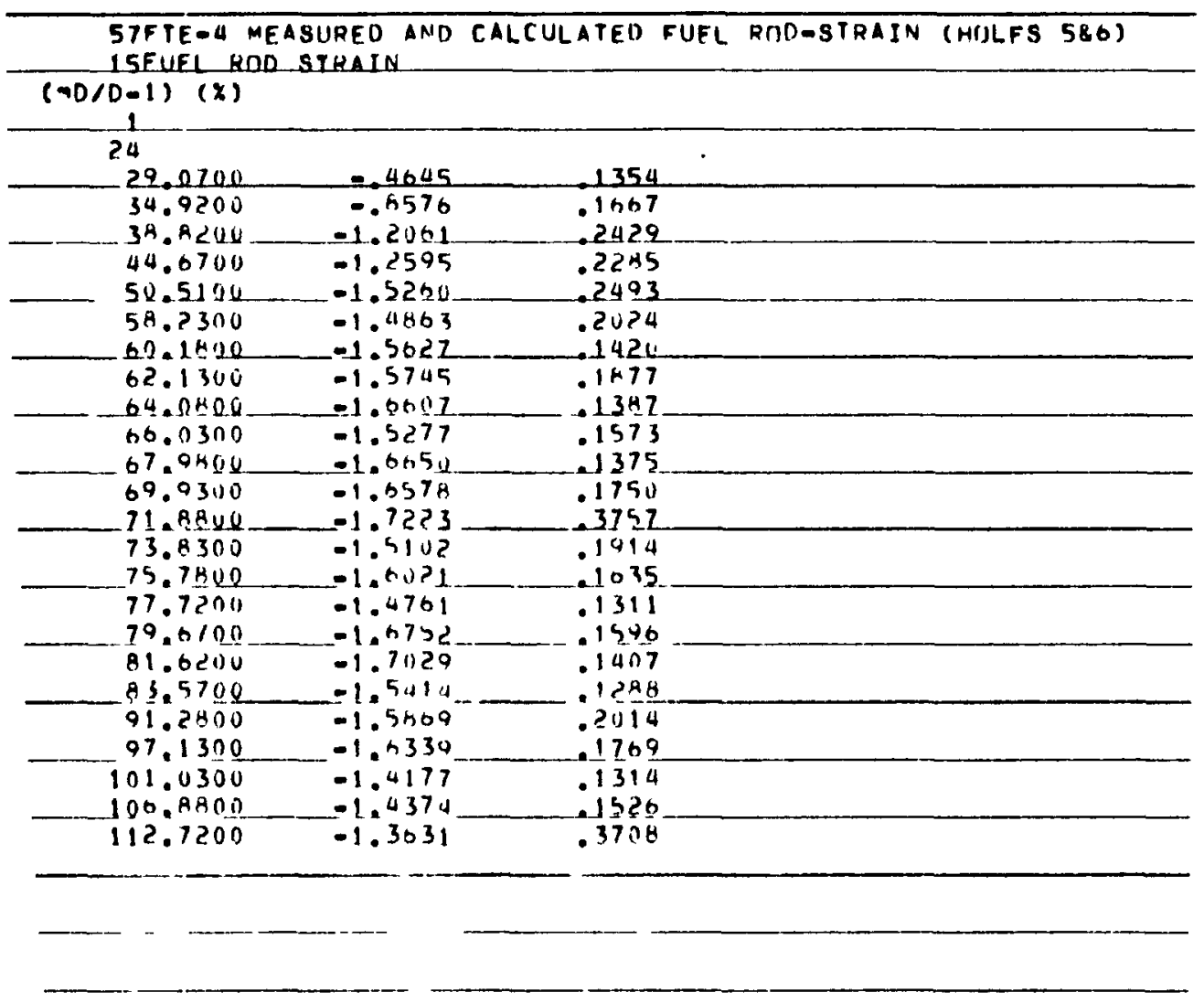


FTE-4 MEASURED AND CALCULATED FUEL ROD STRAIN (HOLES 182)

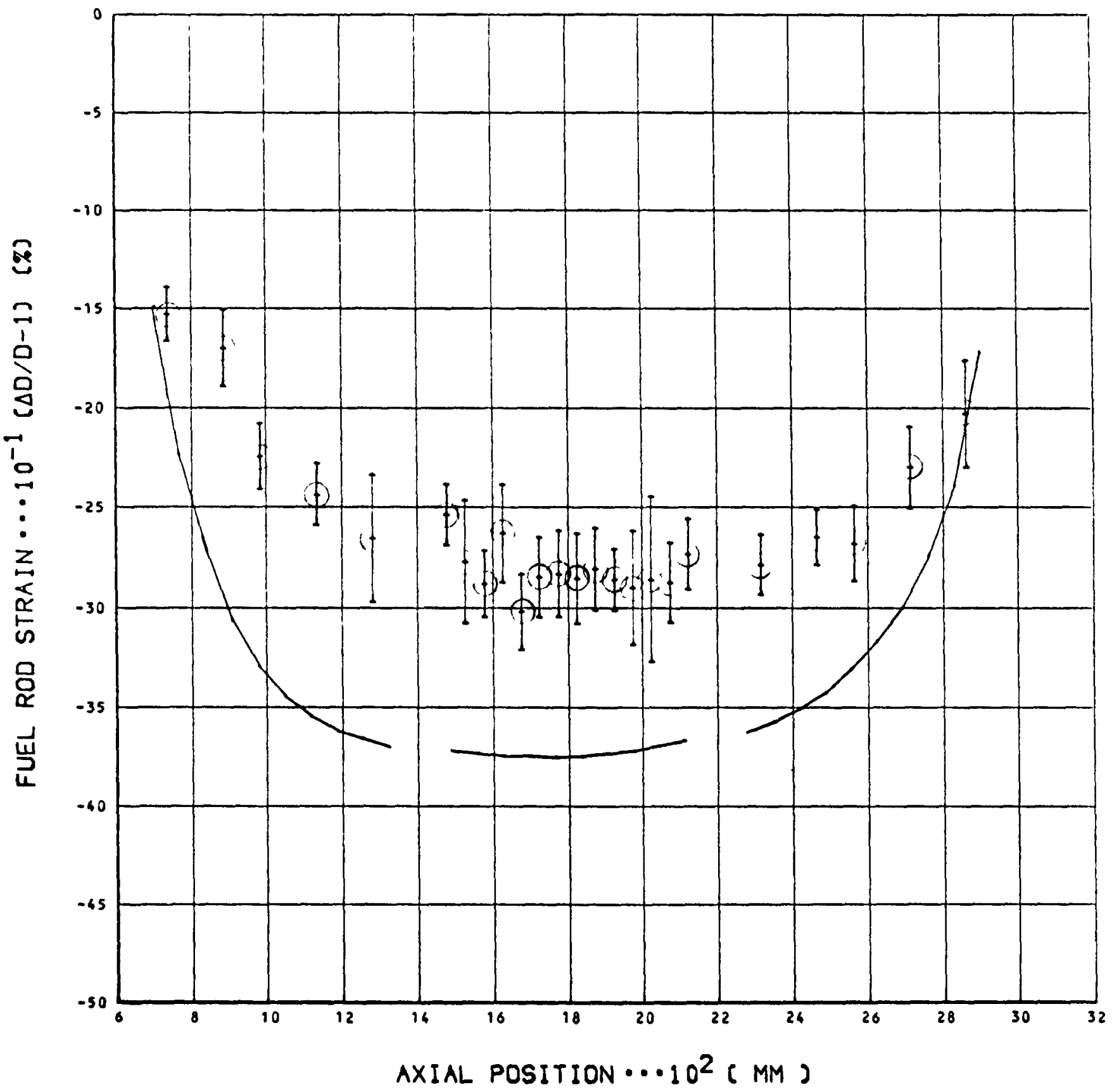


FTE-4 MEASURED AND CALCULATED FUEL ROD-FUEL HOLE GAPS (HOLES 586)

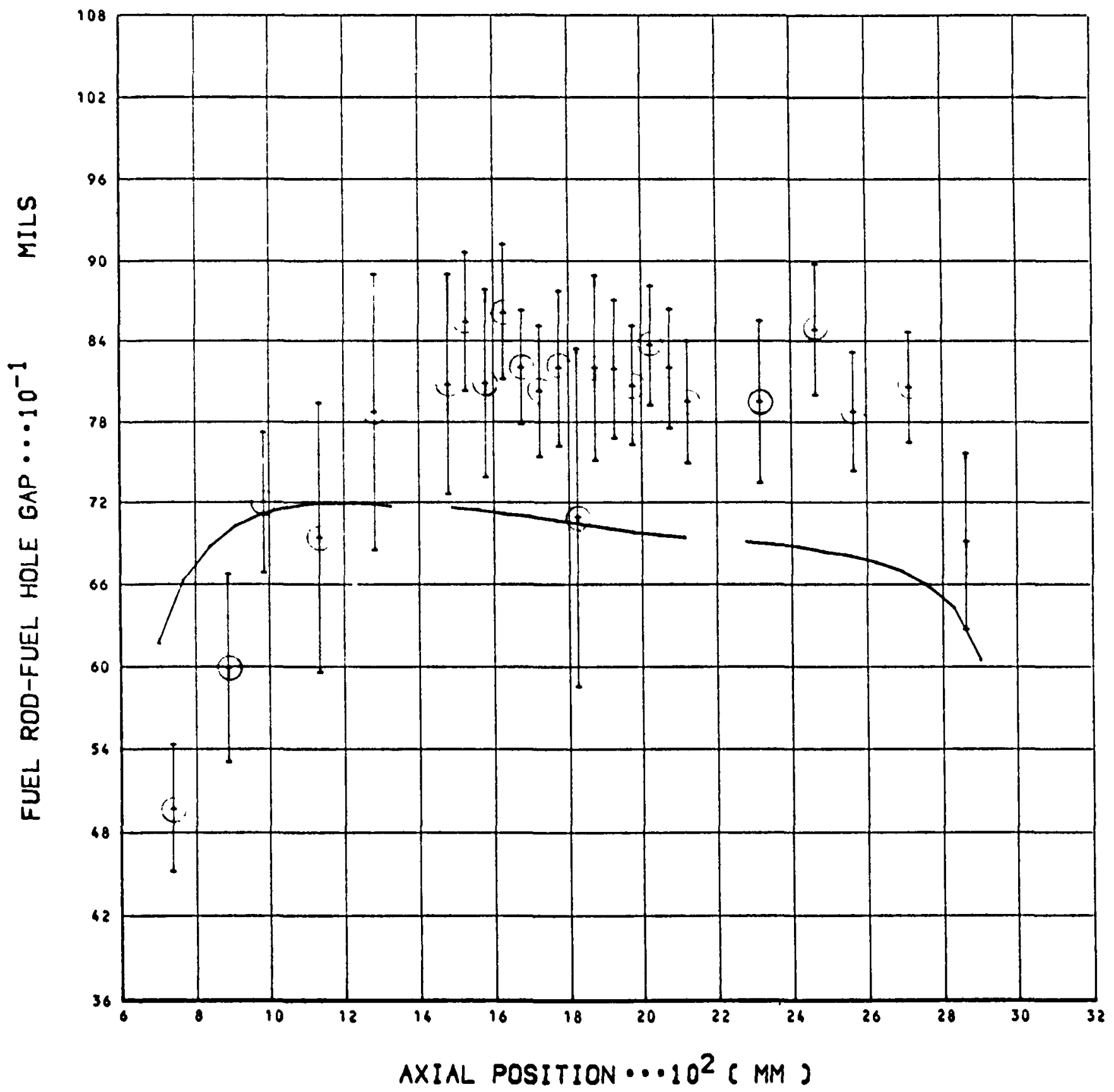


FTE-4 MEASURED AND CALCULATED FUEL ROD-FUEL HOLE GAPS (HOLES $3,4,7,88$ )

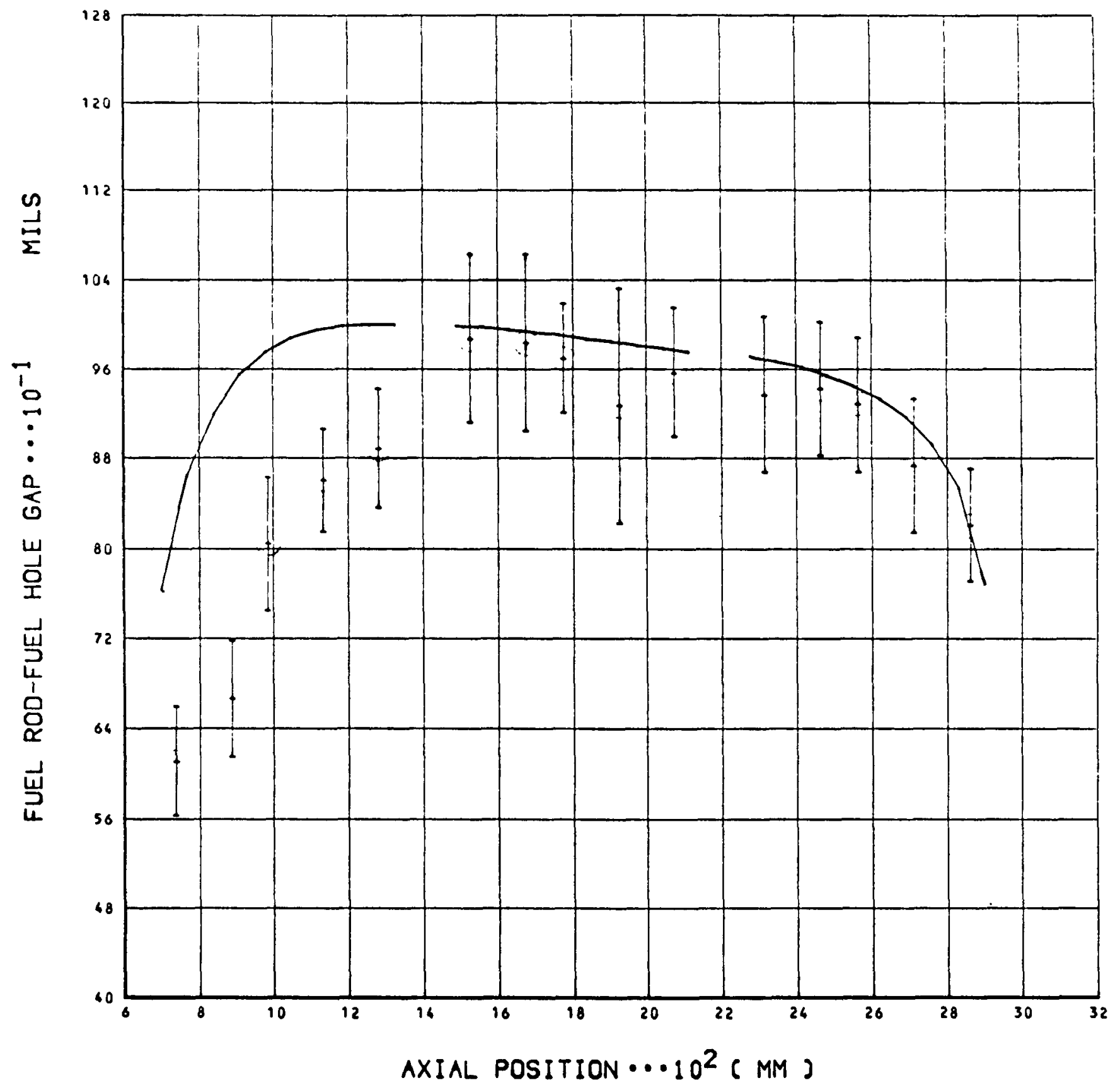


FTE-4 MEASURED AND CALCULATED FUEL ROD-FUEL HOLE GAPS (HOLES 182)

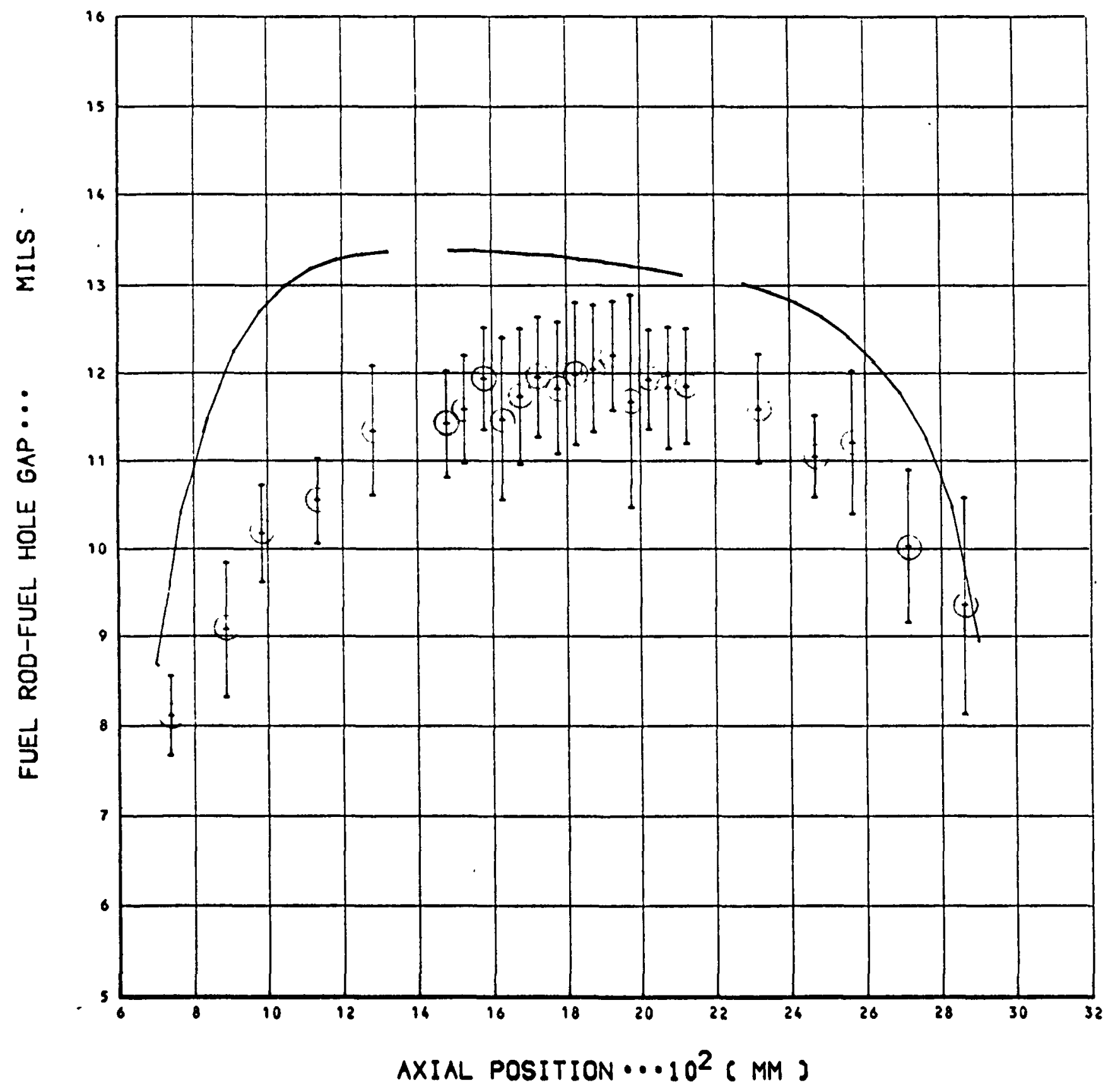


FTE-4 MEASURED AND CALCULATED SLEEVE STRAIN

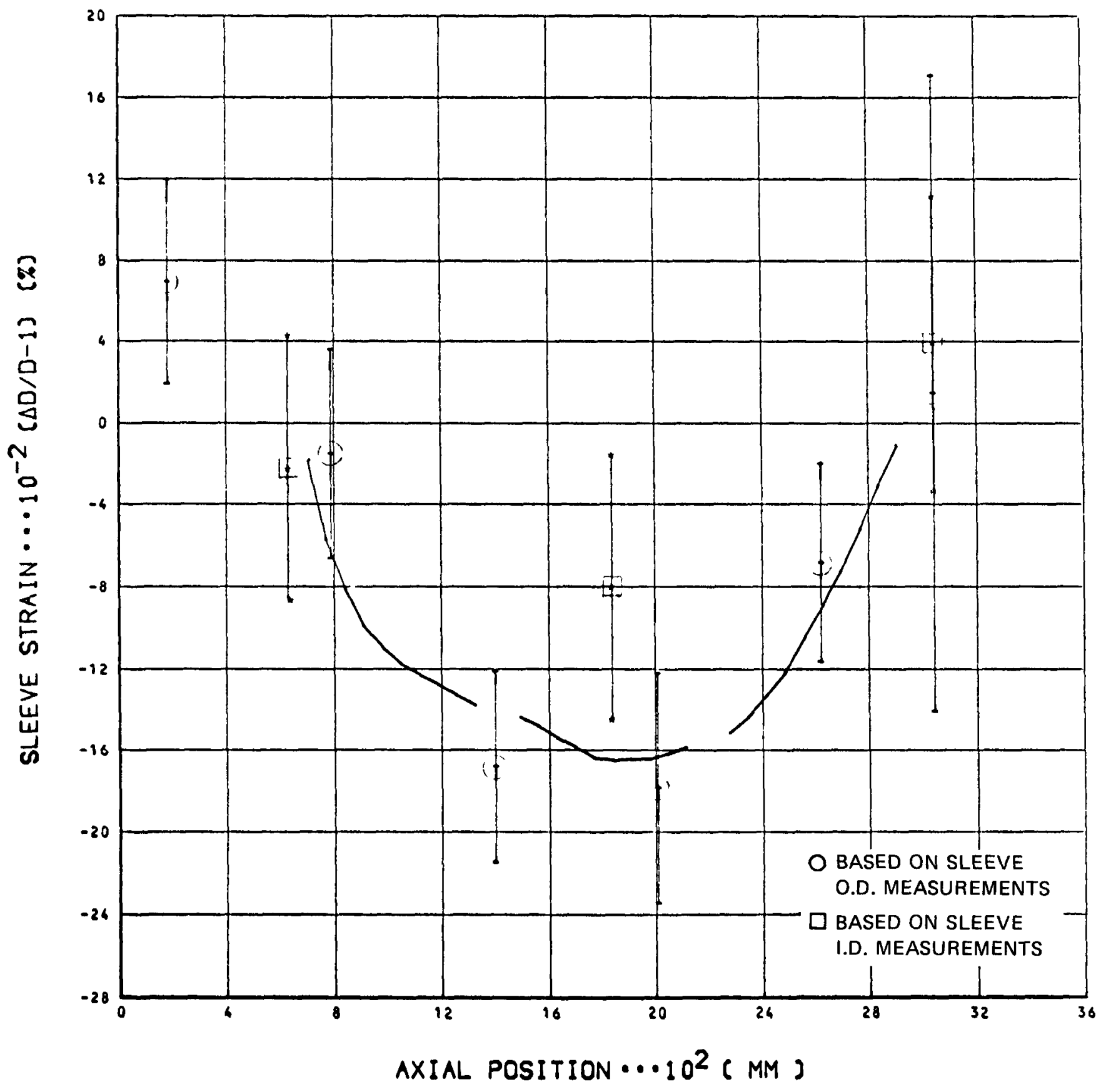




\section{FTE-4 MEASURED AND CALCULATED SLEEVE-FUEL BODY GAPS}

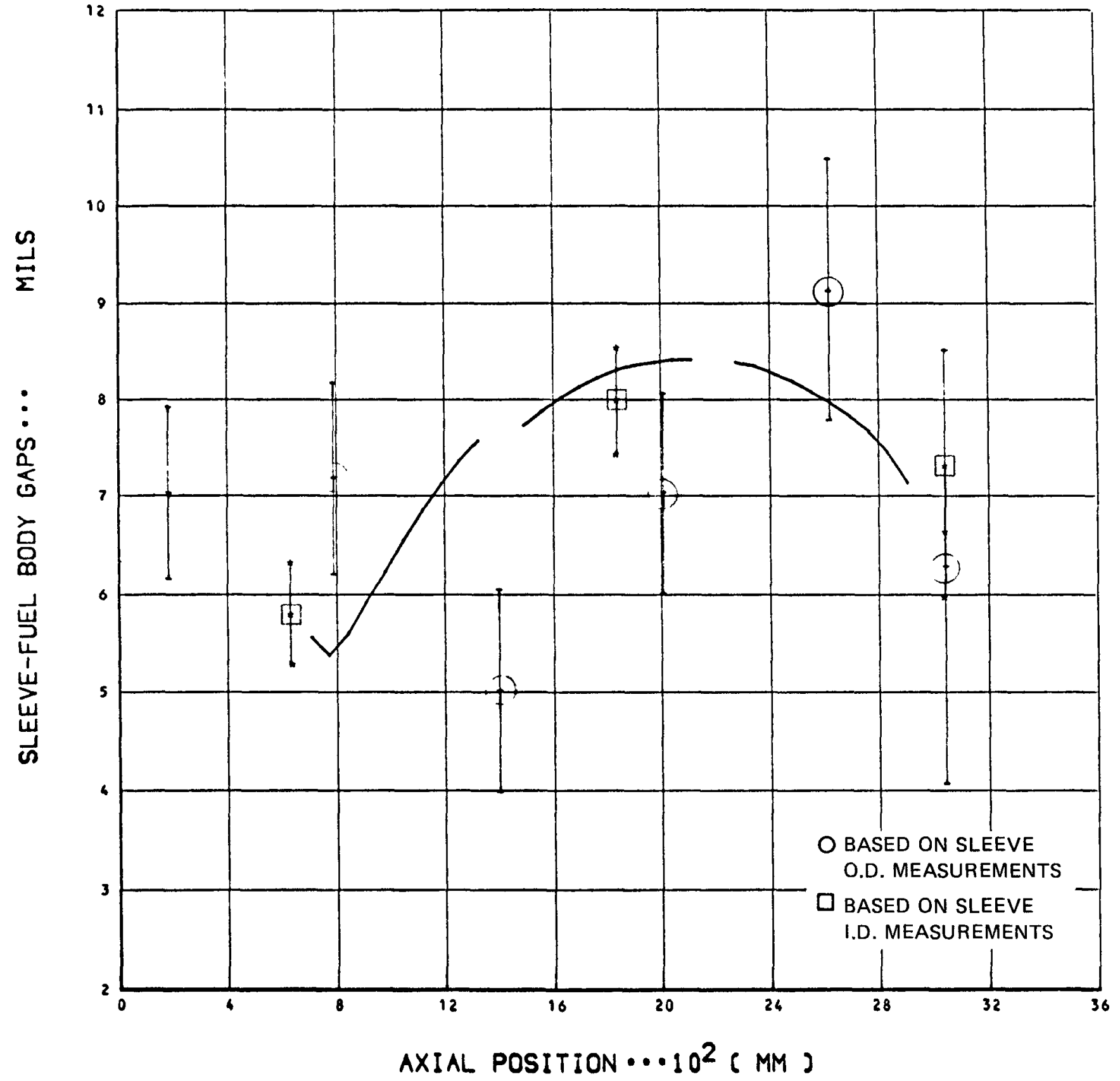


FTE-4 MEASURED AND CALCULATED FUEL ROD STRAIN CHOLES $3,4,788$

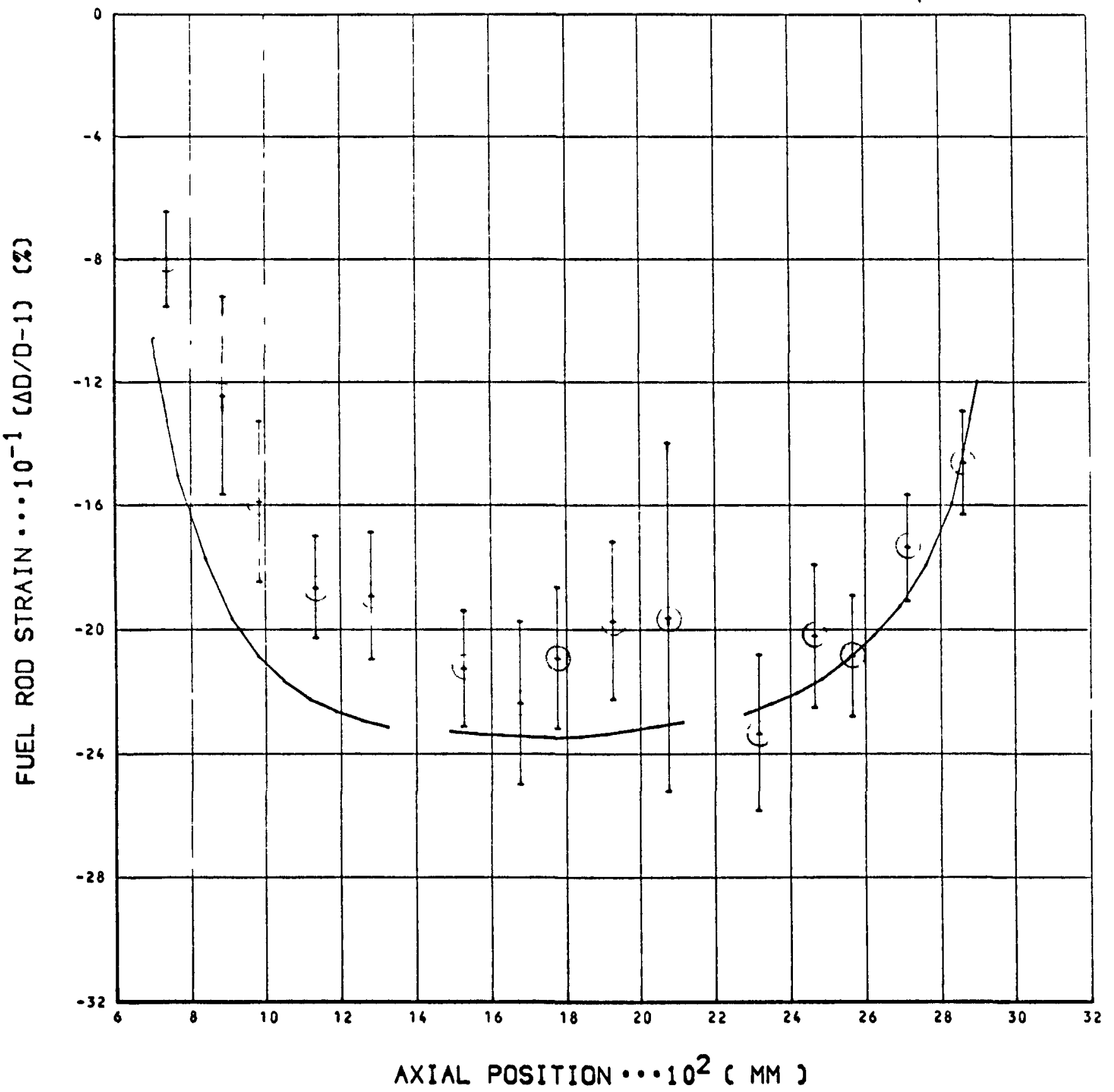


FTE-4 MEASURED AND CALCULATED FUEL BODY STRAIN

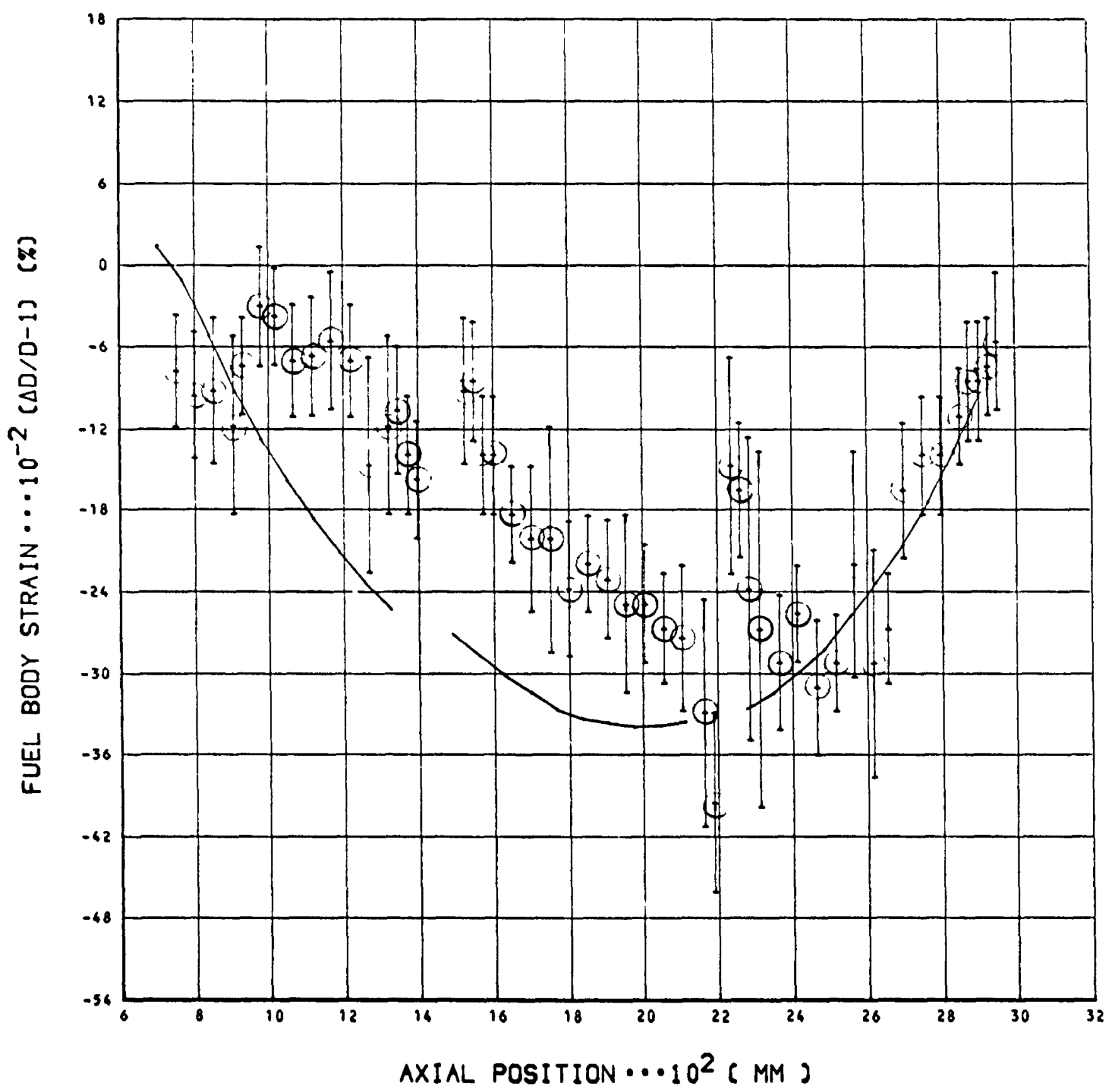


FTE-4 MEASURED AND CALCULATED FUEL ROD-STRAIN (HOLES 5\&6)

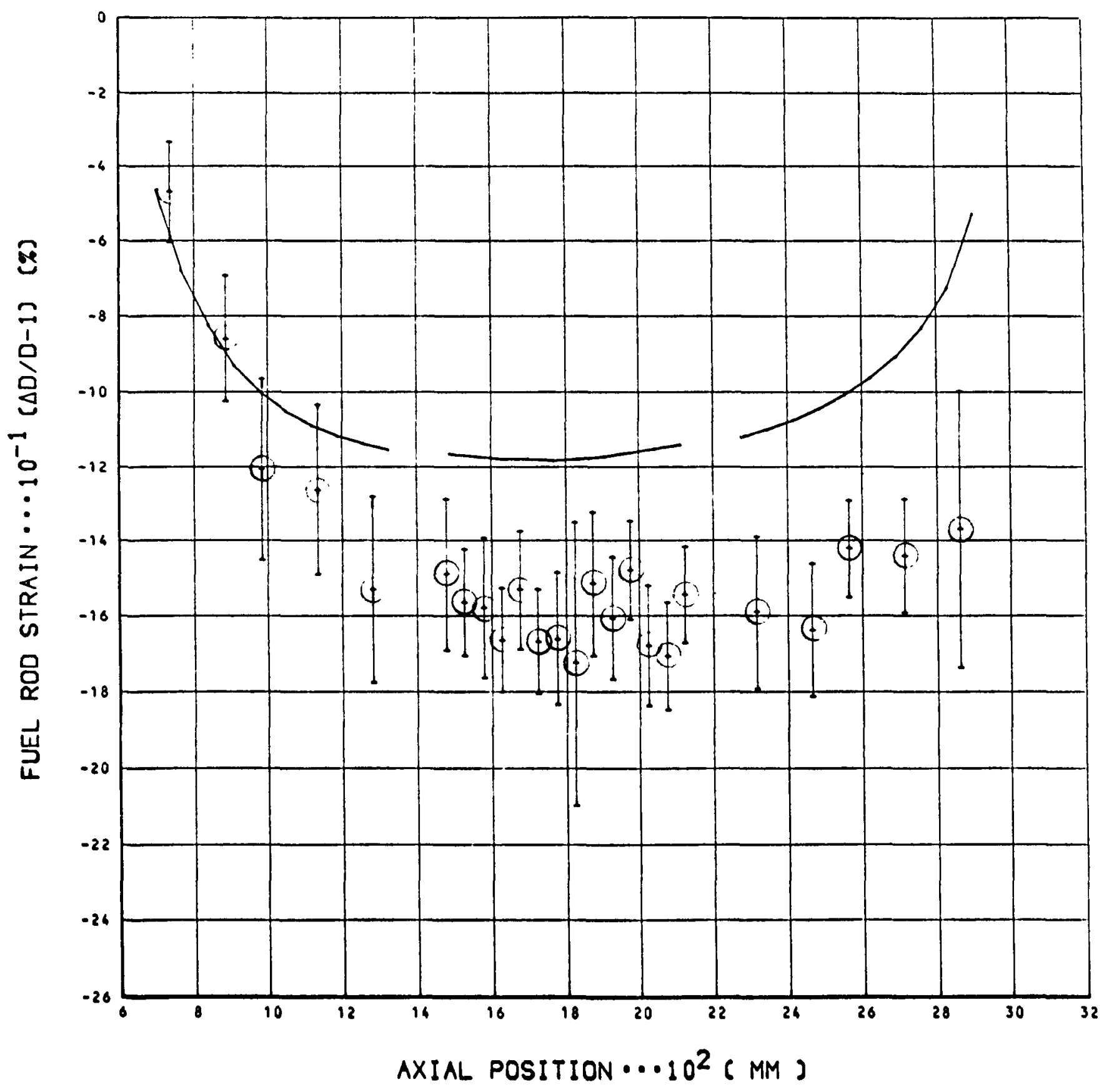


